UNIVERZITET U BEOGRADU

BIOLOŠKI FAKULTET

Ivan I. Šoštarić

Fitohemijska i genetička varijabilnost vrsta iz sekcije Serpyllum (Mill.) Benth. roda Thymus L. (Lamiaceae) u Srbiji

doktorska disertacija

Beograd, 2012 


\section{UNIVERSITY OF BELGRADE}

FACULTY OF BIOLOGY

Ivan I. Šoštarić

\section{Phytochemical and genetical variability of species from section Serpyllum (Mill.) Benth. genus Thymus L. (Lamiaceae) in Serbia}

Doctoral Dissertation

Belgrade, 2011 
Ovde idu mentor i članovi komisije 
Najveću zahvalnost dugujem svojim mentorima prof. dr Zori Dajić Stevanović i prof. dr Petru Marinu, koji su me od početka usmeravali, davali dragocene savete i podstrek da ovaj rad dovedem do kraja. Takođe želim da se zahvalim dr Sofiji Pekić Quarrie, dr Marini Mačukanović Jocić, dr Dragani Rančić, mr Ilinki Pećinar, Svetlani Aćić, Radenku Radoševiću i Maji Terzić, mojim kolegama sa Katedre za agrobotaniku Poljoprivrednog fakulteta Univerziteta u Beograd, koji nisu žalili truda da mi pomognu u svakoj situaciji. Prof. dr Radiši Jančiću, mr Danilu Stojanoviću i ostalim članovima Katedre za Botaniku Farmaceutskog fakulteta Univerziteta u Beogradu sam zahvalan na pomoći i brojnim savetima. Veliko hvala prof. dr Vladi Matevskom koji mi je pomogao svojim neizmernim iskustvom pri determinaciji vrsta ovog komplikovanog roda. Izrada ove disertacije ne bi bila moguća bez svesrdne pomoći prof. dr Zlatka Šatovića i prof. dr Zlatka Libera i njihovih saradnika sa Sveučilišta u Zagrebu, te im se ovom prilikom od srca zahvaljujem. Takođe, veliko hvala i dr Monique Simmonds, dr Renée Grayer i ostalim članovima Jodrell Laboratory, Royal Botanical Gardens Kew, na omogućavanju izvođenja fitohemijskih analiza, kao i na pruženoj pomoći. Neizmerno hvala i velikim botaničarima i ljudima dr Mark W. Chase-u i dr Maichael Fay-u od kojih sam mnogo naučio kako o molekularnim markerima, tako i o strpljenju i toleranciji. Veliku zahvalnost dugujem i dr Stephen Quarrie-u na pomoći i korisnim savetima. Želim i da se zahvalim i mnogobrojnim kolegama, sa kojima sam delio dobro i zlo na terenskim i laboratorijskim ispitivanjima, $\mathrm{mr}$ Ivani Bjedov, $\mathrm{mr}$ Verici Stojanović, Jeleni Arsenijević, Milici Petrović i Milošu Bokorovu.

Naročito se zahvaljujem svojim mnogobrojnim preijatelima bez kojih život ne bi bio zanimljiv.

Hvala i mojim roditeljima na podršci i strpljenju tokom celog života.

Ova disertacija je posvećena Tanji, Sofiji i Marti bez kojih ništa ne bi imalo smisla. 


\section{Fitohemijska i genetička varijabilnost vrsta iz sekcije Serpyllum (Mill.) Benth. roda Thymus L. (Lamiaceae) u Srbiji}

\section{Sažetak}

Rod Thymus je po broju vrsta jedan od najznačajnijih u okviru familije Lamiaceae. U zavisnosti od pristupa autora broj vrsta unutar roda varira, međutim ukoliko se izabere pristup minimalne varijabilnosti, prema raspoloživim podacima opisano je 215 vrsta ovog roda. Vrste ovog roda podeljene su u osam sekcija. U flori Srbije opisana je, do sada, 31 vrsta i preko 100 infraspecijskih taksona, koje sve pripadaju podsekciji Serpyllum, sa izuzetkom vrsta Thymus comptus i Th. striatus (Sect. Hyphodromi) i Th. vulgaris (Sect. Thymus). Reproduktivna izolacija između vrsta ovog roda je izuzetno slaba što čini taksonomska istraživanja još težim.

Vrste roda Thymus koriste se kao lekovite i aromatične biljke u tradicionalnoj i zvaničnoj medicini u svim krajevima u kojima se javljaju. Cilj ovog rada je bio da se opišu različiti hemotipovi unutar vrsta i populaciju ovog roda kao i da se analizom površinskih flavonoida i AFLP markera poboljša uvid u genetičke i evolutivne odnose između populacija vrsta ovog roda sa područja Srbije. U ovo istrživajne uključene su populacije vrsta Th. pulegioides (Subsect. Alternantes), Th. glabrescens, Th. maschallianus i Th. pannonicus (Subsect. Isolepides), Th. balcanus i Th. praecox (Subsect. Peudomarginati)

Analiza sastava etarskih ulja vršena je pomoću TD-GC-MS sistema, a jedinjenja su određen upoređivanjem RI i/ili masenog spektra sa literaturnim podacima. Identifikovana su ukupno 103 jedinjenja. Identifikovane su, po brojnosti, tri glavne grupe jedinjenja: seskviterpenski ugljovodonici, oksigenovani monoterpenski ugljovodonici i monoterpenski ugljovodonici. Statistička obrada sastava etarskih ulja uključila je korelacije, analizu glavnih komponenti i klaster analizu. Statistička obrada je pokazala da se, po relativnoj zastupljenosti jedinjenja, mogu razlikovati geraniolni, fenolni, germakren-D, citralni, linaloolni, $(E)$-kariofilen, $\alpha$-terpinil acetat i linalil acetatni hemotip.

Analiza površinskih flavonoida vršena je pomoću LC-DAD i LC-APCI-MS. Utvrđeno je prisustvo 15 površinskih flavonoida. Ispitivane populacije se mogu podeliti 
u dve grupe. U prvoj grupi su vrste koje imaju niske i srednje količine površinskih flavonoida, kao i one kod kojih su se površinski flavonoidi nalazili samo u tragovima. Kod ove grupe su najzastupljeniji flavoni sa 5,6-diOH-7-OMe i 5,6-diOH-7,8-diOMe supstitucionom šemom u A prstenu. U drugu grupu bi se mogle svrstati populacije koje, uglavnom, imaju malu količinu površinskih flavonoida i kod kojih je su najzastupljeniji flavoni sa 5-OH-6,7-diOMe i 5-OH-6,7,8-triOMe supstitucionom šemom u A prstenu. Prvoj grupi pripadaju populacije vrsta Th. pulegioides, Th. glabrescens i Th. balcanus, kao i neke populacije Th. pannonicus, dok drugoj grupi pripadaju populacije $T h$. marschallianus, neke populacije Th. pannonicus i Th. praecox.

AFLP markeri su korišćeni da bi se utvrdili genetički odnosi između odabranih populacija vrsta roda Thymus, sekcija Serpyllum. Analiza molekularne varijanse (AMOVA) je pokazala da najviše genetičkog diverziteta potiče od razlika među individuama unutar populacija, dok je ostatak diverziteta gotovo jednako raspodeljen između vrsta i između populacija unutar vrsta. Dvosmerna AMOVA je dalje pokazala da je diferencijacija među vrstama bila značajna u svim slučajevima osim između $T h$. marschallianus i Th. pannonicus. Sve jedinke koje su pripadale Th. pulegioides (Podsekcija Alternantes) formirale su dobro podržanu kladu, koja je najviše divergirala od ostalih vrsta. Prema dobijenim rezultatima podsekcija Isolepides je polifiletska. Th. glabrescens se jasno odvaja od druge dve vrste ove podsekcije (Th. marschallianus, Th. pannonicus). Th. marschallianus i Th. pannonicus, iako se jasno razlikuju morfološki po indumentumu, na molekularnim nivo se ne mogu razdvojiti. Vrste koje pripadaju podsekciji Pseudomarginati su formirale monofiletsku kladu, mada ova nije bila podržana visokom bootstrap vrednošću. Ova klada se dalje delila u tri dobro podržane klade koje su predstavljale pojedinačne vrste (Th. balcanus, Th. praecox i Th. moesiacus). 
Primena AFLP markera, u slučaju izabranih vrsta roda Thymus, se pokazala prikladnom za razrešavanje kompleksnih genetičkih odnosa koji uključuju i česte hibridizacije među vrstama, mada striktna retikulatna evolucija ne može biti određena. Svi pokazatelji populacione genetike u sekcij Serpyllum ukazuju da je reproduktivna izolacija među vrstama slaba i uključuje izražen retikulatni sistem, naročito $u$ slučajevima kada se dve ili više vrsta javljaju simpatrički.

Ključne reči: Thymus, etarska ulja, hemotip, površinski flavonoidi, AFLP, genetički diverzitet, retikulatna evolucija. 


\title{
Phytochemical and genetical variability of species from section Serpyllum (Mill.) Benth. genus Thymus L. (Lamiaceae) in Serbia
}

\begin{abstract}
In terms of the number of species, the genus Thymus is one of the most important genera within the Lamiaceae family. The number of species may vary depending on the approach of the author, but if the concept of minimal variability is chosen 215 species have been described. This genus is divided into 8 sections. In Flora of Serbia, 31 species and more than 100 ifraspecific taxa have been described, all of which belong to section Serpyllum, except Thymus comptus and Th. striatus (Sect. Hyphodromi) and Th. vulgaris (Sect. Thymus). Reproductive isolation between species seems to be weak, which makes taxonomical studies in this genus even more difficult.

Species of genus Thymus are used as aromatic and medicinal plants in both traditional and modern medicine in all regions where they grow. The aim of this work was to describe different chemotypes within species and population of this genus and, by analysis of surface flavonoids and AFLP markers, provide better insight into genetic and evolutional relationships among the populations and species of the genus Thymus from Serbia. This work included populations of Th. pulegioides (Subsect. Alternantes), Th. glabrescens, Th. maschallianus and Th. pannonicus (Subsect. Isolepides), Th. balcanus and Th. praecox (Subsect. Peudomarginati).
\end{abstract}

Analysis of essential oils was done by TD-GC-MS system, and compounds were identified by comparing RI and/or mass spectra with published data. 103 compounds were identified. Three major group of essential oil compounds were identified: monoterpene hydrocarbons, oxygenated monoterpene hydrocarbons and sesquiterpene hydrocarbons. Based on relative abundance of compounds, Corelation, PCA and Cluster analysis were performed, and it revealed the existence of several chemotypes, such as geraniol, phenol, germacrene-D, citral, linalool, $(E)$-caryophyllene, $\alpha$-terpinyl acetate and linalyl acetate chemotype.

Analysis of surface flavonoids was done by LC-DAD i LC-APCI-MS. Fifteen different flavones were identified. The analysed populations can be divided into two main profile groups; the first group comprises populations containing generally low and medium concentrations, as well as thoese with trace concentrations of surface 
flavonoids. In this group the dominant flavones were with a 5,6-diOH-7-OMe and 5,6diOH-7,8-diOMe A-ring substitution pattern. The second group comprises populations containing generally low quantities of surface flavonoids, and with dominant 5-OH-6,7diOMe and 5-OH-6,7,8-triOMe A-ring substitution pattern. Th. pulegioides, Th. glabrescens i Th. balcanus, and some populations of Th. pannonicus belong to first group, while Th. marschallianus, some populations of Th. pannonicus and Th. praecox belong to the second group.

Amplified fragment length polymorphism (AFLP) markers were used to assess genetic relations of 32 Thymus populations belonging to seven species of genus Thymus, section Serpyllum from Serbia. Analysis of molecular variance (AMOVA) revealed that most of the genetic diversity was attributable to differences among individuals within populations, while the remaining variability was almost equally distributed among species and among populations within species. The pairwise AMOVA analyses further showed that species differentiation was significant in all cases, except between Th. marschallianus and Th. pannonicus. All the individuals belonging to Th. pulegioides (subsection Alternantes) formed a well-supported clade, the most divergent from all other species in this study. According to these results, the subsection Isolepides is polyphyletic. Th. glabrescens is clearly separated from the other two species of this subsection (Th. marschallianus, Th. pannonicus). Although morphologically distinguishable by leaf indumentum, individuals belonging to $T h$. marschallianus and Th. pannonicus could not be differentiated at the molecular level. The species belonging to subsection Pseudomarginati formed a monophyletic clade, although not supported by high bootstrap value. The clade is further divided into three well-supported clades representing distinct species (Th. balcanus, Th. praecox and Th. moesiacus). 
AFLP markers demonstrated, in the case of selected species of genus Thymus, that they could be suitable for studying complex genetic relationships, including frequent interspecies hybridization events, although strict reticulate evolutionary history could not be determined. All the population genetic parameters in the section Serpyllium suggests that the reproductive incompatibility between species is very weak indicating strong reticulating system, especially in the case when two or more species occur sympatrically.

Key words: Thymus, essential oil, chemotype, surface flavonoids, AFLP, genetic diversity, reticulate evolution. 


\section{Sadržaj}

1. UVOD

1.1. Taksonomski pregled familije Lamiaceae ……………………………………... 2

1.2. Taksonomski pregled roda Thymus i rasprostranjenje ......................................... 4

1.2.1. Istorijska pozadina statusa i infrageneričke klasifikacije roda Thymus.......... 4

1.2.2. Savremena klasifikacija roda Thymus ......................................................... 7

1.3. Naučni pristupi i metode u klasifikaciji vrsta roda Thymus ................................ 12

1.3.1. Morfologija i biologija roda Thymus ......................................................... 12

1.3.2 Fitohemijska istraživanja u okviru roda Thymus ........................................ 15

1.3.3 Kariološka, palinološka i mikromorfološka istraživanja vrsta roda Thymus 31

1.3.5 Molekularna istraživanja ............................................................................. 32

1.4. Opis izabranih taksona roda Thymus ……………………………………..... 33

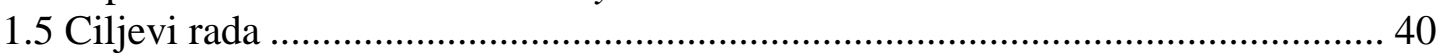

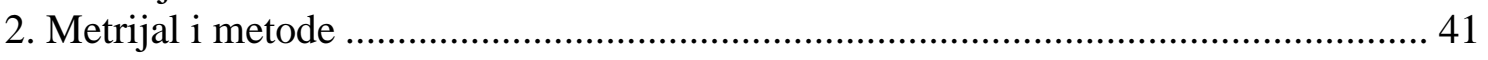

2.1 Fitohemijska ispitivanja................................................................................. 41

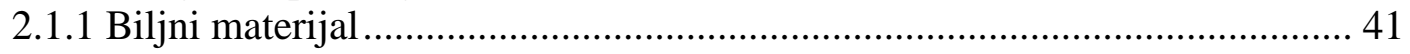

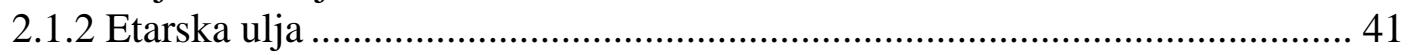

2.1.3 Površinski flavonoidi............................................................................ 45

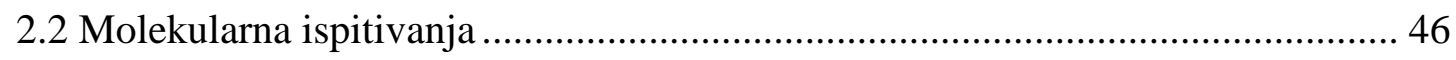

2.2.1 Biljni materijal .......................................................................................... 46

2.2.2 Ekstrakcija DNA i AFLP analiza ………………………………………. 47

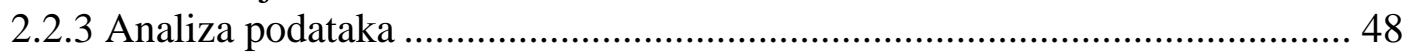

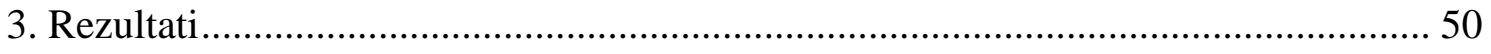

3.1 Fitohemijska ispitivanja............................................................................. 50

3.1.1 Etarska ulja .......................................................................................... 50

3.1.2 Površinski flavonoidi............................................................................. 91

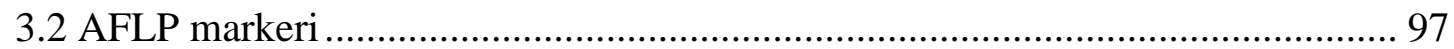

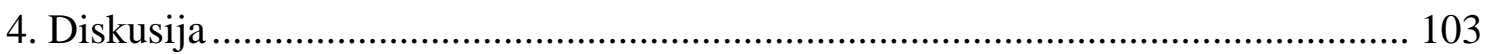

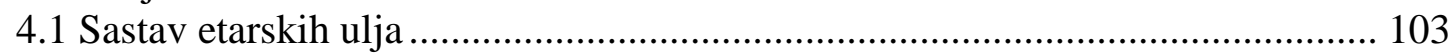

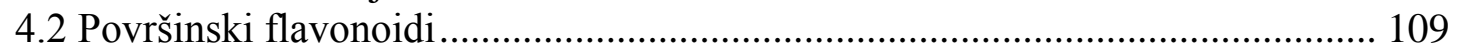

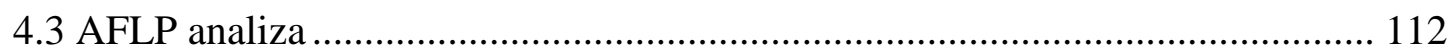

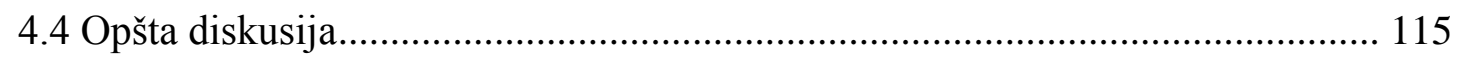

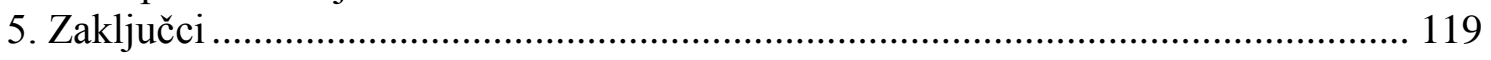

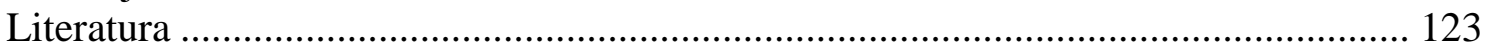




\section{UVOD}

\subsection{Taksonomski pregled familije Lamiaceae}

Predstavnici familije Lamiaceae imaju široko rasprostranjenje na Zemljinoj kugli, prisutni su na svim kontinentima izuzev Arktika. U okviru ove familije nalazi se oko 240 rodova i preko 7200 vrsta (Braüchler i sar., 2010). Klasifikacijom familije Lamiaceae bavili su se mnogi autori, ali najpoznatiji su radovi iz druge polovine XIX veka. Bentham (1876) je podelio familiju Lamiaceae na osam tribusa. Reviziju ove klasifikacije izvršio je Briquet (1895-1897) uzdižući neke od tribusa i subtribusa na nivo podfamilija i kao najupečatljiviju izmenu spojio dva njaveća tribusa i dva manja u jedinstvenu podfamiliju Stachyoideae. Ovaj Briquet-ov sistem klasifikacije je do danas ostao u najširoj upotrebi (Cantino i Sanders, 1986).

Erdtman (1945) je predložio podelu familije Lamiaceae na dve prirodne podfamilije, podfamiliju Lamioideae, sa trikolpatnim polenovim zrnima (retko tetrakolpatnim), koja se raznose u dvoćelijskoj fazi, i podfamiliju Nepetoideae, sa heksakolpatnim polenovim zrnima (retko 8-, 10- ili 12-kolpatna), koja se raznose u troćelijskom obliku. Ovakvu podelu familije Lamiaceae podržala su brojna kasnija istraživanja, koja su osim palinoloških uključila i fitohemijska, embriološka i morfološka istraživanja (Cantino i Sanders, 1986). Međutim, ovakvom podelom familije Lamiaceae, ostao je problem, što je familija Verbenaceae parafiletska, dok je familija Lamiaceae polifiletska. Harley i sar. (2004) su familiju Lamiaceae podelili u sedam podfamilija: Ajugoideae, Lamioideae, Nepetoideae, Prostantheroideae, Scutellarioideae, Symphorematoideae i Viticoideae. Od ovih podfamilija, Nepetoideae su najbolje definisane i odlikuju se, uz već navedene karakteristike, i prisustvom rozmarinske kiseline (Harley i sar., 2004). Takođe, molekularne analize su potvrdile da je ova grupa monofiletska (Wagstaff i sar., 1995; Wagstaff i Olmstead, 1997). Dalja podela ove podfamilije na tribuse uveliko zavisi od viđenja autora. Na osnovu morfoloških karaktera, ali i molekularnih istraživanja, Cantino i sar. (1992) su predložili novu podelu podfamilije Nepetoideae na četiri tribusa: Elsholtzieae, Ocimeae, Lavanduleae i 
Mentheae, pri čemu je ovaj poslednji pretrpeo najveće promene u odnosu na prethodne klasifikacije. Ovakvu podelu su prihvatili i Harley i sar. (2004), s tim da su Lavanduleae uključili u Ocimeae. Tribus Mentheae obuhvata tri subtribusa, Salviinae, Nepetinae i Menthinae, ovom potonjem pripada oko 43 roda, od ukupno 66 rodova tribusa Mentheae, od kojih su mnogi lekovite i aromatične biljke.

Rod Thymus pripada tribusu Mentheae u subfamiliji Nepetoideae (Cantino et al, 1992). Najbliži su mu rodovi Origanum, Satureja, Micromeria i Thymbra. Thymus se smatra dobro definisanim rodom, što je zasnovano na morfološkim i hemijskim karakteristikama (Morales, 2002).

U zavisnosti od pristupa autora broj vrsta unutar roda varira, međutim ukoliko se izabere pristup minimalne varijabilnosti, prema raspoloživim podacima opisano je 215 vrsta ovog roda (Morales, 1996) i jedino su u ovoj familiji veći rodovi Salvia, Hyptis, Scutellaria, Stachys, Teucrium, Nepeta i Plectranthus.

Hibridizacija u okviru roda Thymus je veoma česta kada dve ili više vrsta žive simpatrički. Do danas je na Iberijskom poluostrvu opisano oko 60 hibrida uz 35 vrsta koje su prisutne na ovom području (Morales, 1995). Neka hemijska istraživanja ukazuju da je ovaj rod veoma homogen, za razliku od rodova Teucrium i Sideritis koji su hemijski veoma heterogeni (Morales, 1986). Ove dve karakteristike ukazuju da je rod najverovatinije monofiletski (Morales, 2002). Unutar roda genetska nekompatibilnost izimeđu vrsta gotovo da ne postoji, što čini taksonomska istraživanja veoma teškim, naročito u nekim grupama kao što su na primer sekcija Hyphodromi a naročito sekcija Serpyllum, kod koje je jako teško primeniti koncept vrste (Morales 2002). Prema Moralesu (2002) ukoliko se primeni sinoptički kriterijum, verovatno bi se veliki broj formi, ponekada i ekoloških formi, uključio kao proste populacije u neki takson, međutim ukoliko bi se primenio analitički kriterijum, rizikuje se da se previde postojeće vrste kao prirodne celine. U slučaju nedoumice Morales predlaže primenu sinoptičkog kriterijuma.

Na nivou vrsta u upotrebi je veliki broj imena, više od 1000, od kojih su mnoga sinonimi (Morales, 2002). 
Tabela 1.1 Pregled tradicionalne klasifikacije familije Lamiaceae, prema Cantino i Sanders (1986).

\begin{tabular}{|c|c|c|}
\hline Bentham 1876 & Briquet 1895-1897 & Erdtman 1945 \\
\hline Tribus Ajugeae & $\begin{array}{l}\text { Subfam. Ajugoideae } \\
\text { (uključuje i Rosmarinus iz } \\
\text { Bentham-ovih Salvieae) }\end{array}$ & \multirow[t]{5}{*}{ Subfam. Lamioideae } \\
\hline Tribus Prostanthereae & Subfam. Prostantheroideae & \\
\hline Tribus Prasieae & Subfam. Prasioideae & \\
\hline \multirow[t]{2}{*}{ Tribus Lamieae } & Subfam. Scutellarioideae & \\
\hline & \multirow[t]{4}{*}{ Subfam. Lamioideae } & \\
\hline Tribus Nepeteae & & \multirow[t]{6}{*}{ Subfam. Nepetoidea } \\
\hline Tribeus Salvieae & & \\
\hline Tribus Mentheae & & \\
\hline \multirow[t]{3}{*}{ Tribus Ocimeae } & Subfam. Ocimoideae & \\
\hline & Subfam. Lavanduloideae & \\
\hline & Subfam. Catopherioideae & \\
\hline
\end{tabular}

\subsection{Taksonomski pregled roda Thymus i rasprostranjenje}

\subsubsection{Istorijska pozadina statusa $i$ infrageneričke klasifikacije roda Thymus}

\section{Status i infragenerička klasifikacija roda Thymus pre Linné-a}

Postoji nekoliko pretpostavki o poreklu imena Thymus. Neki autori smatraju da je latinski naziv Thymus izveden iz grčke reči thyo (miris), dok drugo tumačenje uzima grčku reč thymos (snaga, hrabrost) kao etimološki koren imena roda. Isprva je naziv „thymus“ obuhvatao grupu aromatičnih biljaka sa sličnim svojstvima, koje su korišćene za stimulaciju vitalnih funkcija. Mnoga narodna imena za vrste roda Thymus $\mathrm{u}$ romanskim jezicima izvedena su iz latinskog naziva. Isto važi i za englesko ime. U srpskom jeziku vrste ovog roda se nazivaju majčina ili majkina dušica, babina dušica, 
bakina dušica, materina duša, materinka, duša, dušica, paprica, poponac, tamjanika, pismena trava, trup, vrijes (Simonović, 1959; Čajkanović, 1985).

U svom delu iz prvog veka, koje je preveo Laguna 1555. godine, Dioskorides piše o „Thymo“. Međutim, Laguna ne nalazi pod ovim imenom ni jednu vrstu roda Thymus, već biljku koja odgovara rodu Stureja. Na strani 294 Laguna opisuje Serpol, sa dva varijeteta, gajenim i samoniklim, gde bi ovaj drugi Zygis, mogao biti vrsta Thymus-a.

\section{Status i infragenerička klasifikacija roda Thymus po Linné-u}

Interesantno je kako se Linné odnosio prema rodu Thymus u svojim različitim delima. Njegovo znanje se uglavnom zasnivalo na pređašnjim autorima. U delu Hortus Califfortianus (1737) on navodi šest vrsta, od kojih dve poslednje, kako to danas znamo, pripadaju rodovima Satureja i Acinos. Njegov Br. 1 je Th. erectus, što je u stvari Th. vulgaris, Br. 2 je Th. repens, odnosno neka vrsta iz sekcije Serpyllum, Br. 3 je Thymbra capitata i Br. 4 Th. mastichina. U njegovom delu Hortus Upsalensis (1748) pominju se samo Th. vulgaris i Th. mastichina. U delu referentnom za botaničku binomnu nomenklaturu, Species Plantarum 1. izdanje (1753), uključeno je osam vrsta u rod Thymus: 1. Th. serpyllum, 2. Th. vulgaris, 3. Th. zygis, 4. Th. acinos (danas Acinos arvensis), 5. Th. alpinus (danas Acinos alpinus), 6. Th. cephalotos (danas Th. lotocephalus), 7. Th. villosus i 8. Th. pulegioides. U okviru Satureja je 4. Satureja mastichina (danas Th. mastichina).

U Genera Plantarum (1754) Linné navodi, 646. Thymus: Serpyllum, Acinos i Mastichina. U Species Plantarum 2. izdanje (1762) Linné je premestio Th. mastichina (ranije Satureja mastichina) pod rednim brojem 8 u Thymus. U prvom izdanju pod ovim brojem je bio Th. pulegioides. Line ovu promenu objašnjava sličnošću ove vrste sa oba roda. U Systema Nature 2 (12. izdanje, 1767) prvi put se pominje Th. piperella.

\section{Status i klasifikacija roda Thymus nakon Linné -a}

Brotero (1804) je opisao novu vrstu Th. caespititus. Takođe, Hoffmannsegg i Link (1809) u svom radu, Flora Portugalije, opisuju nekoliko novih vrsta, Th. albicans, Th. capitellatus, Th. camphoratus i Th. sylvestris. Bentham (1834) je prvi podelio rod 
Thymus u sekcije: Mastichina, sa Th. mastichina i Th. tomentosus; Serpyllum sa Th. vulgaris, Th. piperella, Th. villosus, Th. capitellatus i Th. capitatus; i Pseudothymbra sa Th. cephalotos (danas Th. lotocephalus).

Edmund Boisser (1839-1845), čuveni švajcarski botaničar iz Ženeve, tokom svojih proputovanja kroz Španiju proučavao je i opisivao vrste roda Thymus sa Iberijskog poluostrva. Takođe je ostavio i vredne opise vrsta ovog roda iz severne Afrike, kao i iz Grčke i Turske, u svom delu Flora Orientalis (1867-1884). U svom delu Elenchus (1838) on je opisao Th. willdenovi, Th. granatensis, Th. longiflorus i Th. membranaceus. 1845 formirao je sekciju Pseudothymbra, a kasnije je opisao Th. carnosus, Th. lusitanicus i Th. baeticus kao varijetet Th. hirtus.

Willkomm (1868), nemački botaničar i autor dela Prodromus Florae Hispanicae, zajedno sa svojim danskim kolegom Lange, smatrao je da se rod Thymus sastoji iz pet sekcija, Mastichina, Zygis, Piperella, Serpyllum i Pseudothymbra. Sekcija Serpyllum bi obuhvatala dve grupe, prva sa Th. chamaedrys, Th. serpyllum i Th. herba-barona i druga sa Th. bracteatus, Th. serpylloides i Th. granatensis.

Briquet (1897) je izvršio reviziju Englerovog monumentalnog dela i opisao dve sekcije, Pseudothymbra i Serpyllum. Ovu drugu je podelio u pet podsekcija: Bracteatae (Th. capitellatus, Th. villosus, Th. algarbiensis, Th. albicans), Serpylla, Piperellae (Th. piperella, Th. caespititus, Th.origanoides, Th. bovei), Vulgares (Th. vulgaris, Th. sabulicola, Th. hyemalis, Th. zygis, Th. carnosus, Th. hirtus) i Mastichinae (Th. mastichina, Th. tomentosus, Th. welwitschii, Th. fontanesii).

Velenovsky (1906) u svom radu o rodu Thymus opisao deset sekcija: Coridothymus, Vulgares, Orientales, Anomali (Th. antoninae, Th. portae), Mastichina (Th. fontanesii), Thymastra (Th. algarbiensis, Th. albicans, Th. capitellatus), Pseudothymbra sa dve grupe (suffructosi: Th. membranaceus, Th. longiflorus, Th. funkii i herbacei: Th. cephalotos, Th. villosus, Th. granatensis), Piperella, Micantes i Serpyllum (u koju je uključio i Th. serpyllastrum).

Najvažniji španski autor koji je proučavao Thymus je Pau, čiji se interes za vrste ovog roda protezao kroz čitav njegov rad. U svom radu iz 1929. godine, "Introducción de los tomillos españoles“, analizirao je predhodne radove Linnéa, Boissera i Willkomma. U ovom radu je dao zanimljive osvrte na vrste roda Thymus. I drugi 
španski autori su se bavili ovim rodom, Huguert del Villar (1934), Vicioso (1974) i Elena-Rosselló (1976), kao i mnogi drugi.

Iako je Španija uvek bila centar taksonomskih istraživnja na Thymus-u, mnogi veliki botaničari van Iberijskog poluostrava su se bavili ovim rodom. Treba posebno istaći Ronniger-a koji je sačinio veoma važan herbarijum, koji se danas nalčazi u Beču, i Jakko Jalas-a, finskog botaničara koji je priredio rod Thymus u Flora Europaea (1972), Flora Iranica (1982) i Flora of Turkey and the East Aegean Islands (1982).

\section{Klasifikacija roda Thymus u Flori Srbije}

Pančić je u svom delu Flora u okolini Beogradskoj (1865) opisao samo Thymus serpyllum. U delu Flora kneževine Srbije (1874) Pančić, uz Th. serpyllum, navodi i Th. nummularius, a u delu Dodatak Flori kneževine Srbije (1884) i Th. striatus. U delu Flora okoline Niša (1882), Petrović navodi vrste Th. serpyllum i Th. striatus, s time da u okviru vrste Th. serpyllum navodi i niže kategorije genuinus, latifolius, nummularis i Pannonicus. U delu Dodatak Flori okoline Niša (1885) Petrović ne navodi nove vrste ali navodi nove odlike angustifolius, acicularis, Serbicus, montanus i citrodus.

Diklić (1974) je u Flori Srbije opisao 31 vrstu i preko 100 infraspecijskih taksona.

\subsubsection{Savremena klasifikacija roda Thymus}

Vrste roda Thymus su rasprostranjene $\mathrm{u}$ aridnim, toplim i hladnim regionima Starog Sveta, severno od Ekvatora pa do obala Grenlanda (Slika 1) (Morales 1989). Region zapadnog Mediterana se smatra centrom diverziteta ovog roda. Rod je podeljen na osam sekcija: Mastichina, Micantes, Piperella, Pseudothymbra, Thymus, Teucrioides, Hyphodromi i Serpyllum (Jalas 1971). 


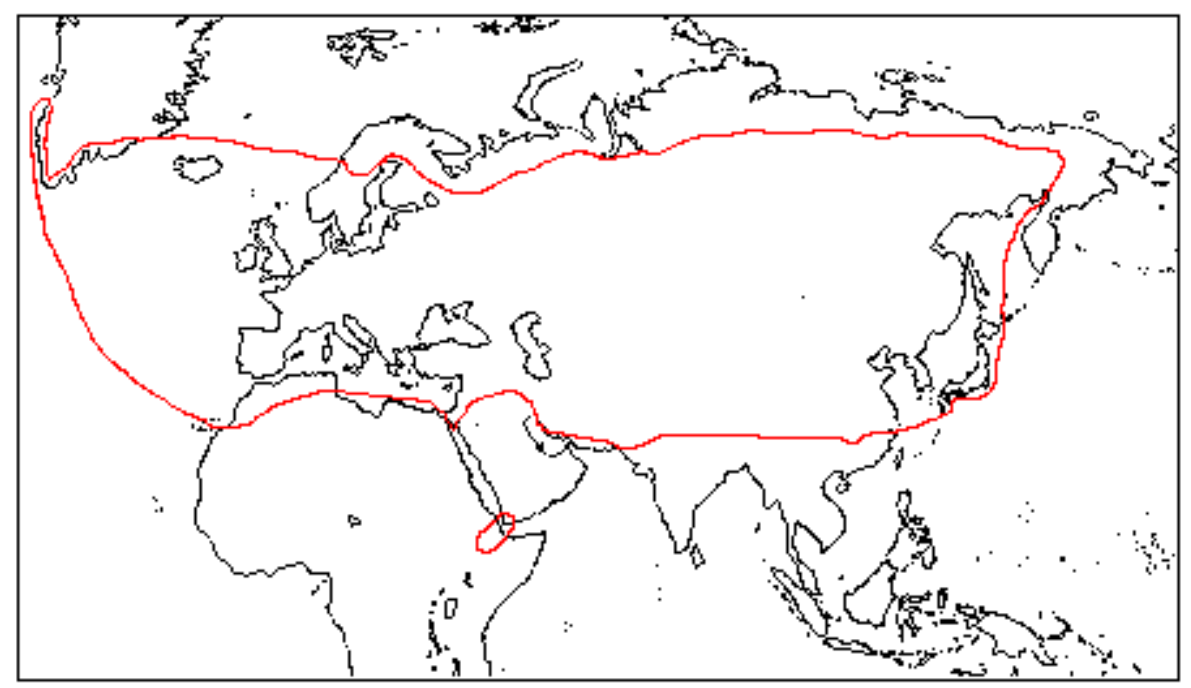

Slika 1.1 Areal roda Thymus (Prema Morales, 2002).

Prvih pet se nalaze samo na Iberijskom poluostrvu, severozapadnoj Africi i Makroneziji (Zapadni Region). Ovih pet sekcija je manje više dobro proučeno (Morales 1986, 1994).

Sekcija Mastichina obuhvata dve vrste koje se nalaze samo na Iberijskom poluostrvu: Th. mastichina, ili divlji majoran, i Th. albicans.

Skcija Micantes obuhvata zeljastu Iberijsko-Makronezijsku vrstu Th. caespititus koja se nalazi u severozapadnom Atlanskom regionu Pirinejskog poluostrva i na Maderi i Azorskim ostrvima, i drvenaste vrste iz Maroka, Th. saturejoides i Th. riatarum.

Sekcija Piperella se sastoji od samo jedne endemične vrste Th. piperella iz istočne Španije.

Sekcija Pseudothymbra se karakteriše sa prisustvom dugih brakteja i cvetova. U nekim slučajevima su krunice dugačke i do $2 \mathrm{~cm}$. Od 9 vrsta, 7 su nađene na jugu Pirinejskog poluostrva (Th. lotocephalus, Th. villosus, Th. longiflorus, Th. membranaceus, Th. moroderi, Th. funkii, Th. antoninae) dok 2 rastu u severozapadnoj Africi (Th. bleicherianus, Th. munbyanus).

Sekcija Thymus zastupljena je samo u zapadnom Mediteranu, i najvažnije vrste su Th. vulgaris, Th. zygis i Th. willdenowii. Th. vulgaris je rasprostranjena u severnoj Italiji, južnoj Francuskoj i u istočnom delu Španije, ova vrsta se danas inače gaji kao lekovita i začinska biljka u mnogim delovima Sveta. Th. zygis je veoma česta vrsta na Iberijskom poluostrvu, dok je Th. willdenowii rasprostranjen u Maroku, Alžiru i Gibraltaru. Ovoj sekciji, takođe, pripadaju i vrste Th. capitellatus i Th. camphoratus iz 
Portugalije, Th. carnosus koji se javlja samo na jugo-zapadu Iberijskog poluostrva, $T h$. baeticus, Th. loscosii, Th. serpylloides, svi endemit Španije, i Th. hyemalis sa jugoistoka Španije i severnog Maroka.

Sekcija Teucrioides je endemična za Balkansko poluostrvo. Vrste ove sekcije naseljavaju planine Grčke i Albanije. Ovom sekcijom su obuhvaćene tri vrste: Th. teucrioides, Th. rechingeri i Th. leucospermus. Ovu sekciju je proučavao Hartvig (1987), međutim, broj hromozoma još uvek nije poznat.

Sekcija Hyphodromi se javlja u celom regionu Mediterana i obuhvata oko 60 vrsta, svrstanih u tri podsekcije, Subbracteati, Serpyllastrum i Thymbropsis.

Podsekcija Subbracteati se karakteriše manje više revolutnim ili konvolutnim listovima i ima najverovatnije poreklo iz istočnog Mediterana. Samo jedna vrsta je prisutna u severnoj Africi, Th. algeriensis, od Maroka pa do Libije. Th. mastigophorus se javlja u centralnoj Španiji. Th. spinulosus je prisutan na Sicililji i u Italiji, a Th. striatus se javlja na Apeninskom i Balkanskom poluostrvu. Ove poslednje dve vrste su veoma varijabilne. Th. aragaeus, Th. brachychilus, Th. cappadocicus, Th. cherlerioides, Th. convolutus, Th. pulvinatus i Th. revolutus se javljaju u Turskoj, Th. boisseri, Th. comptus, Th. dolopicus i Th. plasonii na Balkanskom poluostrvu, Th. atticus, Th. paranassicus i Th. leucotrichus u Turskoj i Balkanskom poluostrvu, s tim da se poslednja vrst javlja i u Siriji i Libanu. Th. integer je endemit Kipra, međutim verovatno se ne razlikje od Th. leucotrichus. Th. samius se javlja na ostrvima u Egejskom moru. Th. borysthenicus i Th. pallasianus imaju areal severno od Crnog Mora, Th. persicus se javlja južno od Kavkaza, međutim poznat je samo jedan lokalitet ove vrste.

Podsekcija Serpyllastrum je grupa vrsta karakterističnih po prostratnim stablima i ravnim listovima koji su manje više široki. Pet vrsta iz ove podsekcije naseljava Španiju: Th. bracteatus, Th. leptophyllus, Th. fontqueri, Th. granatensis i Th. lacaitae. Ova podsekcija je takođe rasprostranjena na istoku Mediterana, međutim ni jedna vrsta ne nastanjuje severnu Afriku i Italiju. Th. aznavoutii i Th. bracteosus se javljaju na Balkanskom poluostrvu. Th. canoviridis, Th. hausskenechtii, Th. pectinatus i Th. spathulifolius su rasprostranjeni u Turskoj, dok se areal vrste Th. zygoides proteže preko Balkanskog i Krimskog poluostrva i Turske. Ova vrsta i endemit Španije, Th. lacaitae su morfološki izuzetno slični. Ovoj podsekciji pripada i grupa vrsta koje se javljaju samo na Kavkazu: Th. dagestanicus, Th. hadzhievii, Th. helendzihcus, Th. karjaganii, 
Th. ladjanuricus, Th. lipskyi, Th. majkopiensis i Th. sosnowskyi; kao i sedam vrsta iz centralne Azije: Th. cuneatus, Th. eremita, Th. incertus, Th. irtychensis, Th. kirgisorum, Th. nerczensis i Th. petraeus.

Podsekcija Thymbropsis obuhvata severnoafričke vrste Th. broussonetii, Th. maroccanus, Th. lanceolatus, Th. numidicus, Th. pallescens kao i dva endemita Grčke, Th. laconicus i Th. holosericus. Ovde spadaju još pet vrsta iz Turske, Th. cariensis, Th. cilicicus, Th. eigii, Th. leucostomus i Th. sipyleus. Th. syriacus se javlja u Libanu, Siriji i jednom lokalitetu u severnom Iraku, Th. bovei se javlja na Sinajskom poluostrvu, u Izraelu, Jordanu, Iraku i Saudijskoj Arabiji, dok se Th. decussantus javlja na Sinaju i u Saudijskoj Arabiji. Ovo je grupa uglavnom severnoafričkih i istočnoazijskih vrsta.

Sekcija Serpyllum se smatra najstarijom u rodu. Obuhvata oko 125 vrsta i pokriva ceo areal roda, osim Madeire i Azorskih ostrva. U okviru ove sekcije javlja se i najveća varijabilnost u broju hromozoma. Ovoj sekciji pipadaju kako manje više drvenaste vrste koje naseljavaju planine u suvim regionima, kao na primer $T h$. origanoides sa Kanarskih ostrva, Th. serrulatus i Th. schimperii iz Etiopije i Th. laevigatus sa jugo-zapada Arabijskog poluostrva, tako i manje više zeljaste vrste koje nastanjuju planine Mediteranskog regiona i ostatak Evroazije sve do Japana i južnih obala Grenlanda. Ova potonja grupa izgleda da je u evolutivnom smislu mlađa i verovatno intenzivno evoluira i kolonizuje nova područja od poslednje glaciacije. Sekcija Serpyllum obuhvata sedam podsekcija.

Podsekcija Insulares sadrži vrstu Th. willkommii koja je endemit Španije, zatim Th. richardii sa tri podvrste; supsp. richardii koja se javlja na Majorci i u Jugoslaviji, subsp. ebusitanus sa Ibice i subsp. nitidus sa ostrva Maretimo pored Sicilije. Th. dreatensis i Th. guyonii su severnoafričke vrste, dok je Th. origanoides endemit Kanarskih ostrva. Th. bornmulleri je endemit severozapadne Turske.

Podsekcija Kotschyani obuhvata veliki broj Azijskih vrsta i u području Mediterana se javljaju samo Th. transcaucasicus i Th. fallax u Turskoj. Iz ove podsekcije su još zanimljve vrste Th. laevigatus iz planina Jemena, Th. schimperi i Th. serrulatus iz Etiopije.

Podsekcija Pseudopiperellae obuhvata vrste Th. herba-barona, koja je rasprostranjena na Majorci, Korzici i Sardiniji (Mayol et al, 1990), i Th. nitens sa juga Francuske. 
Pet vrsta koje naseljavaju Balkansko poluostrvo pripada podsekciji Isolepides. To su Th. bulgaricus, Th. glabrescens, Th. longedentatus, Th. pannonicus i Th. sibthorpii.

Podsekcija Alternantes obuhvata Th. linearis sa Himalaje i evropske vrste Th. pulegioides, Th. feoelichianus, Th. alpestris, Th. oehmianus, Th. bihorensis i Th. comosus.

Podsekciji Pseudomarginati pripadaju vrste Th. longicaulis i Th. praecox koje su veoma česte u Evropi i Turskoj, kao i Th. nervosus koji je endemit Pirinejskog poluostrva i Centralniog masiva u Francuskoj. Ovoj podsekciji takođe pripadaju Th. ocheus, Th. stojanovii i Th. tracicus sa Balkanskog poluostrav i istočnog Mediterana.

Podsekcija Serpyllum obuhvata Th. quinquecostatus iz Japana, evropsku vrstu Th. serpyllum, Th. talijevii i još neke vrste rasprostranjene u Rusiji.

Podela roda Thymus koju je dao Menitsky (1973) značajno se razlikuje od one koju je dao Jalas (1972), i kasnije, podržao Morales (1985). On je rod Thymus podelio na jedanaest sekcija. Sekcije Thymus, Teucrioides, Mastchina, Pseudothymbra i Piperella se ne razlikuju između ova dva autora.

Menitsky ne navodi sekciju Hyphodromi već podsekciji Subbracteati, kako je shvata Jalas, odgovaraju sekcija Orientales i gupa Th. striatus iz sekcije Serpyllum, podsekcija Isolepides. Podsekcija Thymbropsis je izdvojena u posebnu sekciju, a podsekcija Serpyllastrum, po Menitsky-om, pripada sekciji Serpyllum.

Menitsky navodi sekciju Saturejoides i u okviru sekcije Serpyllum podsekciju Micantes koje bi odgovarala Jalasovoj sekciji Micantes.

Najveće razlike između dva sistema klasifikacije su u odnosu na sekciju Serpyllum. Menitsky je Th. serrulatus iz podsekcije Koschyana uvrstio u sekciju Serrulatus, a ostale vrste iz podsekcije Koschyana uključio u sekciju Marginati. Ostale podsekcije, sekcije Serpyllum, kako ih vidi Menitsky, su Micantes, Serpyllastrum, Isolepides, koja nikako ne odgovara onoj kod Jalasa, i Serpyllum.

Menitsky opisuje sekciju Marginati sa dve podsekcije, Marginatii i Verticillati. Predstavnici iz ove sekcije, po Jalas-u, pripadaju sekciji Serpyllum i to podsekcijama Pseudopiperella, Insulares, Kotschyana, Alternantes, Pseudomarginati i Isolepides. U ovom radu koristiće se klasifikacija roda Thymus po Jalas-u (1971). 
Sve vrste opisane u našoj flori pripadaju skciji Serpyllum osim vrsta Thymus comptus i Th. striatus (Sect. Hyphodromi) i Th. vulgaris (Sect. Thymus), koja je unesena u našu floru i gaji se kao začinska i lekovita biljka.

\subsection{Naučni pristupi i metode u klasifikaciji vrsta roda Thymus}

\subsubsection{Morfologija i biologija roda Thymus}

Biljke roda Thymus se karakterišu prema svom habitusu odnosno životnoj formi. Mogu se razlikovati dve grupe, jednu čine predstavnici koji imaju oblik žbunova, ne viši od $50 \mathrm{~cm}$, kao na primer Th. baeticus i Th. hyemalis sa Iberijskog poluostrva, i druge koja obuhvata predstavnike sa puzećim stablima katkada sa adventivnim korenima. Ova životna forma je veoma česta kod vrsta iz skcija Serpyllum i Hypodromi. Th. caespititus predstavlja izuzetak sa cespitoznim habitusom koji može da ima veoma dugačke izdanke. Kao i večina predstavnika Lamiaceae, Thymus na poprečnom preseku ima četvrtasta stabla. Mladi izdanci su prekriveni dlakama. Dlake mogu prekrivati sve četiri strane stabla (holotrichous), dve naspramne strane, koje se smenjuju po internodijama (alelotrichous) ili se mogu nalaziti samo na rebrima (goniotrichous) (Slika 3). Uloga različitih tipova dlaka na stablu još uvek nije razjašnjena. 

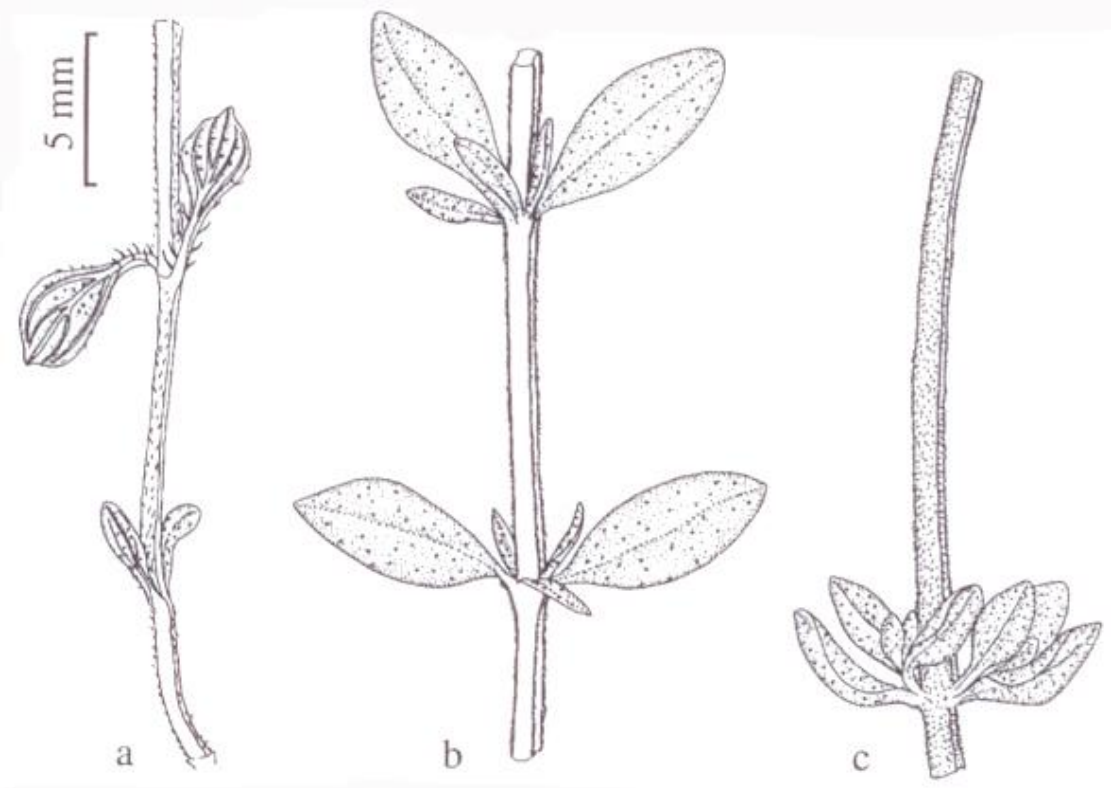

Slika 1.2. Pokrivenost stabla trihomima: a) alelotrichous (Th. praecox); b) goniotrichous (Th. pulegioides) i c) holotrichous (Th. piperella) (iz Morales, 2002).

Listovi mogu biti uži ili širi sa ravnom lisnom pločom ili mogu biti sa podavijenim ivicama (revolutni). Indumentum je veoma varijabilan. Tektorne dlake kod Thymus-a su uvek proste, ali retko jednoćelijske. Listovi su često sa trepljama na obodu, bilo celom dužinom, bilo samo pri osnovi i petioli. Glandularni trihomi su veoma bitni pošto sadrže etarska ulja. Postoje dve vrste grandularnih trihoma: kapitatne žlezde sa gornjom ćelijom punom etarskih ulja i peltatne žlezde sa ćelijama u osnovi koje su tipične za Lamiaceae.

Cvetovi se uglavnom javljaju u grupama u nodusima. Mali broj vrsta ima samo dva cveta po nodusu (Th. antoninae), a znatno češće se u nodusima nalazi veći broj cvetova. Vrste sa kraćim internodijama imaju loptaste i glavičaste cvasti. Ukoliko je ovo slučaj, brakteje se razlikuju po obliku i veličini od ostalih listova. Ovo naročito važi za Th. membranaceus, Th. carnosus i druge pripadnike skcija Pseudothymbra i Thymus. Kod nekih vrsta brakteje mogu biti izuzetno dugačke, kao npr kod Th. satureioides.

Čašica kod Thymus-a u suvom stanju igra veoma važnu ulogu pri rasejavanju plodova. S tim u vezi grlo je zatvoreno sa dlakama i vetar je može preneti na velike udaljenosti. Čašice kod nekih vrsta, kao npr. Th. mastichina, imaju izduženi zub prekriven cilijama koji služi za rasejavanje slično papusu kod Asteraceae. Čašica obično 
ima pet zubaca, tri gornja i dva donja, gde su ovi potonji uvek duži i obično savijeni na gore. Oni verovatno imaju ulogu u pričvršćivanju cevi krunice. Kod nekih vrsta tri gornja zupca su redukovana na jedan (Th. caespititus). Krunica varira od 4 do10 mm u dužinu i završava se sa jednim gornjim i tri donja lobusa. Ovo je tipična struktura za oprašivanje pčelama ili drugim sličnim insektima. Produkcija polena u četiri prašnika je niska.

Kod populacija iz roda Thymus je česta ginodiecija, odnosno da se $\mathrm{u}$ populacijama javljaju dva tipa jedinki, one koje imaju hermafroditne cvetove i one sa cvetovima bez prašnika. Pokazano je da oprašivači brže oprašuju ženske cvetove od hermafroditnih.

Plod je merikarpijum koji se raspada na četiri orašice, međutim često neke abortiraju tokom ranih faza razvića.

Ukoliko se ovi svi karakteri posmatraju sa evolutivnog stanovišta, smatra se da su vrste sa ravnim listovima i bez dlaka primitivnije od onih sa revolutnim listovima $\mathrm{i}$ trepljama na obodu. Takođe loptičaste cvasti sa cvetovima čije se brakteje razlikuju od ostalih listova smatraju se izvedenijim. Drvenaste vrste sa uspravnim odrvenelim stablima su, verovatno, filogenetski starije od onih sa zeljastim izdancima, odrvenelim samo pri osnovi (Morales, 2002), prikaz evolutivne istorije roda dat je na Slici 1.3. 


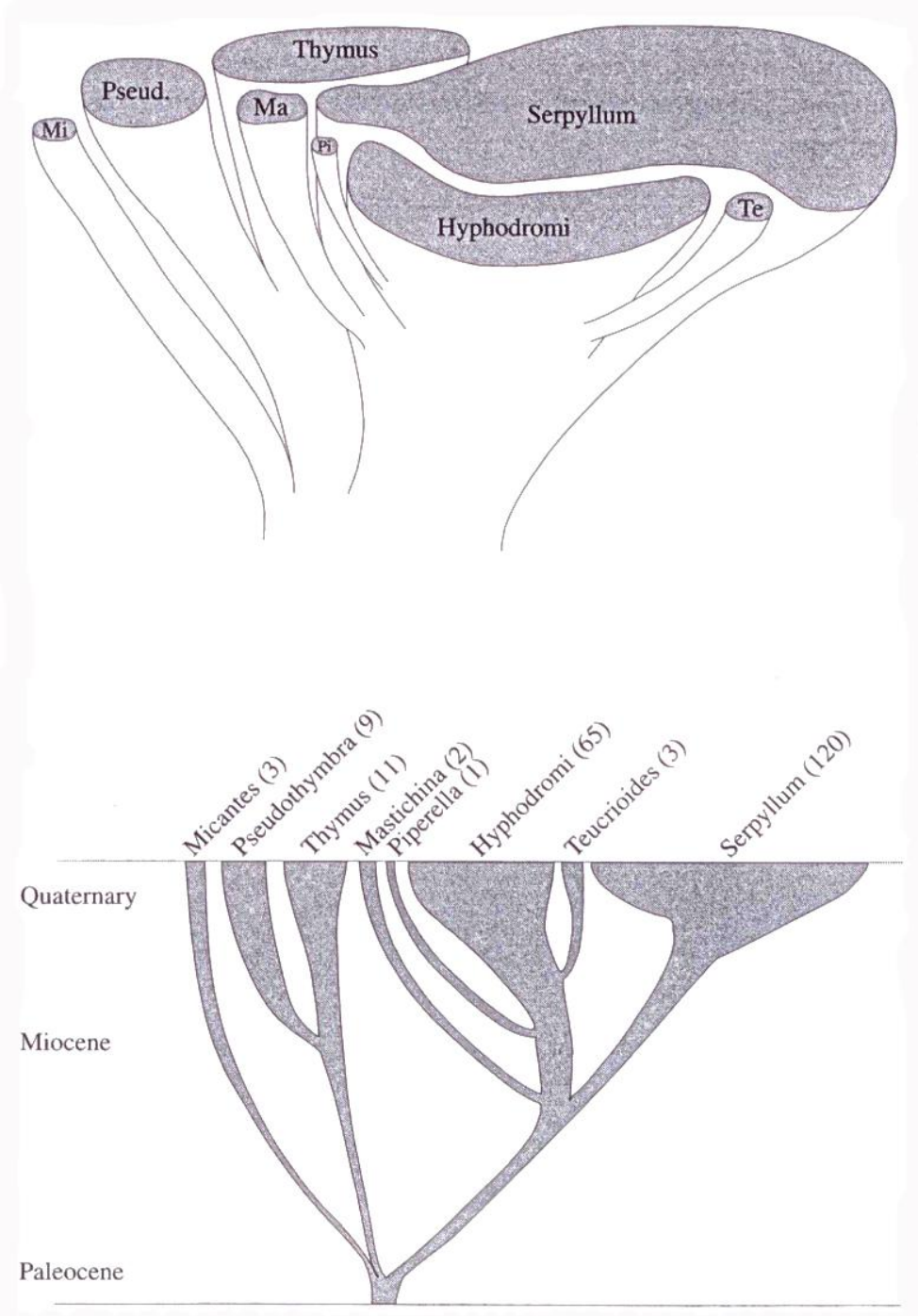

Slika 1.3. Evolutivni odnosi unutar roda Thymus, u zagradama je dat broj vrsta (Morales 2002).

\subsubsection{Fitohemijska istraživanja u okviru roda Thymus}

\subsubsection{Sastav etarskih ulja}

Vrste roda Thymus, kao i mnogi drugi predstavnici familije Lamiaceae, su aromatične biljke, žlezdani trihomi na listovima i drugim delovima biljke su bogati monoterpenoidnim etarskim uljima (Thompson, 2002). Najveći broj komponenti etarskih ulja pripadaju grupi monoterpena, čak i do 90\%. Seskviterpenska jedinjenja su 
uvek prisutna $\mathrm{u}$ etarskom ulju kod Thymus, međutim, uglavnom u veoma malom procentu. U uljima roda Thymus opisano je prisustvo oko 270 terpena. Međutim njihovo samo prisustvo nije dovoljno za karakterizaciju roda već se treba uzeti u obzir i kvantitativni aspekt svake komponente (Stahl-Biskup, 2002).

Prema broju taksona u kojima su zastupljeni, timol i karvakrol su najznačajnije komponente etarskih ulja. Taksoni koji ne sadrže ova fenolna jedinjenja mogu se svrstati u nefenolnu grupu. U okviru fenolne grupe su i taksoni sa bilo timolom ili karvakrolom, bilo i sa jednom i sa drugom koponentom. Osim kod Thymus-a ova dva jedinjenja se javljaju u veoma ograničenom broju taksona. Unutar familije Lamiaceae samo neke vrste iz rodova Coridothymus, Origanum, Satureja i Monarda imaju timol i karvakrol kao glavne komponente etarskih ulja. U ostatku biljnog sveta samo je kod vrste Trachyspermium copticum (Apiaceae) utvrđeno prisustvo ove dve komponente (Stahl-Biskup, 2002).

Prisustvo i visok procenat monoterpenskih ugljovodonika, $p$-cimena i $\gamma$ terpinena, ne može se posmatrati nezavisno od prisustva timola i karvakrola, pošto su ova jedinjenja prkursori fenolnih jedinjenja, tako da se ona uglavnom javljaju istrovremeno $\mathrm{u}$ etarskim uljima, mada ponekad procenat ova dva jedinjenja prelazi procenat prisustva fenola, ovakva ulja se ipak mogu smatrati „fenolnim“ (Stahl-Biskup, 2002).

Linalool je treća komponenta po važnosti u okviru roda Thymus. U etarskom ulju kod velikog broja populacija javlja se sa preko 10\%. Za razliku od fenolnih komponenti linalol ima slatkast miris i biljke sa dominantnim linalolom imaju sasvim drukčiji karakter. Ovo takođe važi i za geraniol. Linalol je veoma široko rasprostranjena komponenta u biljnom svetu i Thymus nije glavni izvor ove komponente već su mnogo značajnija lavanda (Lavandula angustifolia), ili muskatna žalfija (Salvia sclarea), kao i Coriandrum sativum (Apiaceae). Kod nekih vrsta roda Thymus, populacije sadrže i fenolne jedinke i linalolne jedinke.

Sa borneolom na šestom mestu po prisutnosti, biciklična monoterpenska struktura dobija na značaju. Kod taksona kod kojih prelazi $10 \%$ uglavnom se nalazi zajedno sa strukturno sličnim monoterpenima, kao što su kamfor i kamfen. 1,8-cineol se nalazi na sedmom mestu. U etarskim uljima često se javlja zajedno sa kamforom i borneolom, i odgovoran je za relativno često prisustvo kamfora koji je čest i u uljima 
borneolnog tipa. Eukaliptol (1,8-cineol) je česta komponenta kod predstavnika familije Myrtaceae, naročito u okviru vrsta roda Eucalyptus, ali je takođe glavna komponenta ulja vrste Rosmarinus officinalis (Lamiaceae). Ostale komponente etarskih ulja nisu prisutne u značajnom broju taksona roda Thymus, ipak po značaju se mogu izdvojiti $\alpha$ terpinil acetat, $\alpha$-terpineol, geranil-acetat, kamfor, citral (geranial+neral), linalil-acetat, mircen i terpinen-4-ol.

Kako je već navedeno, kod vrsta roda Thymus seskviterpenska jedinjenja nisu previše značajna. Najčešći je $\beta$-kariofilen koji je prisutan u etarskim uljim mnogih biljnih vrsta. Ovo jedinjenje je registrovano kod određenog broja vrsta Thymus u procentu većem od 10\%, ali nikada nije registrovan kao glavna komponenta etarskih ulja. Ovo takođe važi i za germakren-D koji je veoma često prisutan u etarskim uljima, ali retko prelazi $10 \%$. Znatno je ređe prisustvo oksigenovanih germakrena koji su uz Tkadinol i nerolidol široko rasprostranjeni kod vrsta Thymus-a severne Evrope.

Neterpenoidna alifatična jedinjenja prisutna su u etarskim uljima mnogih vrsta roda Thymus, ali u malim procentima. Jedinjenja sa lancem od osam ugljenikovih atoma su najčešće, kao na primer oktanol-3, okten-1-ol-3, oktil-3 acetat i okten-1-il-3 acetat. Odgovarjući heksanski derivati su sledeći po zastupljenosti, a potom nonanski derivati. Uz ova jedinjena česti su i određena jedinjenja sa razgranatim lancima. Do sada je opisano prisustvo 62 neterpenoidna alifatična jedinjenja u etarskim uljima različitih vrsta roda Thymus.

Neterpenoidna aromatična jedinjenja sačinjavaju $\mathrm{C}_{6} \mathrm{C}_{1^{-}}, \mathrm{C}_{6} \mathrm{C}_{2^{-}}$i $\mathrm{C}_{6} \mathrm{C}_{3^{-}}$-derivati, od kojih su ova poslednja poznata i kao fenilpropanska jedinjenja. Sva zajedno sačinjavaju negde oko 7,8\% konstituenata ulja kod Thymus. Od ove grupe jedinjenja najznačajnija su izoeugenol i cinamol, pošto se bar kod jedne vrste Thymus javljaju sa više od $10 \%$. Sva ostala jedinjenja iz ove grupe se, uglavnom, javljaju u tragovima.

\subsubsection{Populaciona varijabilnost sastava etarskih ulja}

Biljke u okviru iste populacije mogu varirati u odnosu na glavnu monoterpensku komponentu etarskih ulja. U prirodnim populacijama Th. vulgaris sa juga Francuske uočeno je prisustvo jednog ili nekoliko od ukupno šest hemotipova. Ovih šest hemotipova dobili su oznaku prema glavnoj komponenti etarskih ulja, geraniol, $\alpha$ - 
terpineol, tujanol-4, linalool, karvakrol i timol (Passet, 1971; Vernet i sar., 1986). U populacijama iz Španije nije utvrđeno prisustvo geraniol hemotipa, dok je primećen sedmi hemotip 1,8-cineol (Adzet i sar., 1977a). Neki od ovih hemotipova se mogu prepoznati i na terenu samo na osnovu čula mirisa, što je naročito iskazano kod geraniol tipa, koji ima izražen miris na limun, kao i kod dva fenolna hemotipa koji imaju karakterističan miris timijana, što ih jasno razlikuje od nefenolnih hemotipova.

Prvi opisi varijabilnosti etarskih ulja kod Th. vulgaris javili su se ranih šezdesetih godina XX veka (Granger i sar., 1963), a usledile su znatno podrobnije studije u narednih nekoliko godnia.

Ekološka uloga sekundarnih metabolita može se podvesti pod tri kriterijuma, adaptacija na abiotičke uslove sredina, kompetitivne interakcije sa drugim biljkama (McPherson i Muller, 1969) i hemijska odbrana od herbivora i patogena (Simeon de Bouchberg i sar., 1976; Bryant i sar., 1991; Shonle i Bergelson, 2000). Jasno je da ovi faktori ne deluju nezavisno jedan od drugog, već je dinamika sekundarnih metabolita uslovljena kombinovanim uticajem abiotičkih i biotičkih faktora sredine.

Postoji određeni dokazi koji pokazuju da varijabilnost monoterpenske komponente može predstavljati adaptivnu strategiju u relaciji sa uslovima sredine (Thompson, 2002). Prvi dokaz adaptivne varijacije predstavlja geografska i lokalizovana distribucija hemotipova kod Th. vulgaris u južnoj Francuskoj. Na osnovu podataka dobijenih analizom sekundarnih metabolita združenih uzoraka biljaka iz južne Francuske primećeno je da fenolni hemotipovi (timol i karvakrol) dominiraju u populacijama timijana sa toplih i suvih staništa blizu Sredozemnog mora, dok nefenolni hemotipovi (geraniol, linalol, alfa-terpinol i tujanol-4) dominiraju u populacijam koje su dalje u kopnu, naročito iznad 400m nadmorske visine, to jest, na staništima sa vlažnijom i hladnijom klimom (Passet, 1971; Granger i Passet, 1973). Ovo je potvrđeno ispitivnajem i upoređivanjem učestalosti biljaka svakog hemotipa u 15 populacija od kojih su neke bile sa malih nadmorskih visina (ispod 300m), a neke sa nadmorskih visina preko 400m (Thompson i sar., 2003). Kod populacija koje sus rasle preko 400m nadmorske visine nisu pronađene fenolne jedinke.

Prostorni raspored hemotipova kod Th. vulgaris javlja se i na manjim područjima, od svega $8 \times 10 \mathrm{~km} \mathrm{u}$ dolini Martin-de-Londres, u okolini Monpeljea u Francuskoj (Vernet i sar., 1977 a, b; Gouyon i sar., 1986). Ova dolina ima specifičnu 
mikroklimu, gde tokom zime temperatura u dolini može biti i nekoliko stepeni niža nego na obroncima brda koja je okružuju. Ovde je na osnovu zbirnih uzoraka biljaka utvrđeno da u dolini dominiraju nefenolni hemotipovi, dok na plićim zemljištima $i$ toplijim mestima na obroncima brda dominiraju fenolni hemotipovi.

U studiji 336 populacija Th. vulgaris utvrđeno je prisustvo oko $20 \%$ populacija sa samo jednim hemotipom, 165 populacija, ili oko 50\%, sa dva hemotipa, od kojih je 72 bilo sa dva nefenolna hemotipa, 69 sa dva fenolna hemotipa, dok je svega 24 populacije sadržavalo jedan fenolni i jedan nefenolni hemotip (Gouyon i sar., 1986). Ovo ukazuje da, iako su populacije sa dva hemotipa česte, on sa nefenolnim i fenolnim hemotipom predstavljaju retkost.

Raspored hemotipova je u korelaciji sa tipom zemljišta na kojem se neka populacija razvija. Fenolne populacije se javljaju na suvljim i plićim zemljištima nego nefenolne populacije koje su vezane za vlažnija i dublja zemljišta. Među nefenolnim hemotipovima utvrđeno je da je $\alpha$-terpineol hemotip najčešći na najvlažnijim podlogama, dok je, što se fenolnih tiče, karvakrol hemotip najčešći na najsuvljim podlogama, a timolni hemotip nije u toj meri specijalizovan (Gouyon i sar., 1986).

Drugi jasan faktor koji utiče na zastupljenost određenih hemotipova je temperatura. Uočeno je odsustvo fenolnih hemotipova, a naročito karvakrolnog, iz delova staništa koja su izložena temperaturama ispod $0^{\circ} \mathrm{C}$. Ovo je moguća posledica što su nefenolne jedinke manje izložene oštećenjima usled niskih temperatura od fenolnih, $\mathrm{s}$ obzirom da su fenolna jedinjenja toksičnija od nefenolnih ukoliko dođe do oštećenja ćelija (Thompson, 2002).

Kod populacija različitih vrsta roda Thymus sa Balkana, takođe je utvrđeno postojanje različitih hemotipova.

U flori Makedonije opisan je veliki broj taksona ovog roda. Za Th. albanus ssp. albanus navodi se da je glavna komponenta etarskih ulja (E)-neroldiol, a sledi $\beta$ kariofilen (Kulevanova i sar., 1998c), za Th. jankae, kod koga su ispitivana tri varijeteta, var. jankae, var. pantotrichus i var. patentipilus, utvrđeno je da je glavna komponenta linalool, a na drugom mestu geranial (Kulevanova i sar., 1998a). Kod Th. longidens var. dassareticus glavna komponenta je $\alpha$-terpinil acetate, a slede sa približno istim koncentracijama, $\alpha$-terpineol, linalool i geraniol (Kulevanova i sar., 1996a). Kod Th. longidens var. lanicaulis utvrđeno je postojaje dva hemotipa, kod jednoga je glavna 
komponeta karvakrol, a kod drugog timol, dok je u oba slučaja drugi po zastupljenosti geraniol (Kulevanova i sar., 1996a). Kod Th. macedonicus ssp. macedonicus utvrđeno je postojanje hemotipa kod koga je glavana komponenta geraniol (Kulevanova i sar., 1996; 1999), linalool i $\alpha$-terpinil acetat (Kulevanova i sar., 1999). Glavna komponenta ispitivanog etarskog ulja Th. moesiacus iz Makedonije je geraniol (Kulevanova i sar., 1996b), a kod Th. rohlenae p-cimen (Kulevanova i sar., 1998b). Kod vrste Th. tosevii ispitivano je više infraspecijskih takson i utvrđeno postojanje nekoliko hemotipova sa različitim glavnim komponentama etarskog ulja, geraniol, $\alpha$-terpinil acetat, timol i karvakrol (Kulevanova i sar.,1995; 1996c; 1997).

\subsubsection{Flavonoidi}

Do sada je identifikovan veliki broj biljnih pigmenata, koji su podeljeni u četiri osnovne grupe: flavonoidi, karotenoidi, hinonoidi i betalaini. Flavonoidi su dalje podeljeni na antocijane, žute falvonoide i bezbojne flavonoide (Marin, 1995).

Antocijanini su najznačajnija grupa hemijskih komponenti odgovornih za boju određenog biljnog organa i tkiva. Sa njihovim ispitivanjem je početo u prvoj polovini 20. veka, ali struktura pojedinih antocijanina nije bila potpuno objašnjena te je postojala potreba za ponovnim ispitivanjem. Nakon otkrića da su malonilovani (zwitterionic) antocijanini veoma česti kod Lamiaceae, mnoge vrste su ponovo ispitane (Harborne i Boardley, 1985; Harborne i sar., 1986).

Žuti flavonoidi su odgovorni za žutu boju kod niza biljnih vrsta. Ovo je kompleksna grupa pigmenata koja je dalje podeljena na sledeće grupe: žuti flavonoli, žuti flavoni, halkoni i auroni. Poslednje dve grupe poznate su još pod nazivom antohlori. Žuti flavonoli zasnovani su na dve komponente - gosipetinu i kvercetagetinu (Marin, 2003).

Gosipetin i njegovi derivati su, do sada, nađeni u 12 familija cvetnica, a čak su detektovani i kor rastavića (Equisetum). Kvercetagetin je nešto manje rasprostranjen, detektovan je kod oko 8 familija. Oba tipa žutih flavonola prisutna su u dve velike familije cvetnica, Asteraceae i Fabaceae (Harborne, 1975).

Najpoznatiji žuti flavoni, koji odgovaraju gore pomenutim flavonolima, su hipolaetin i 6-hidroksiluteolin. Međutim oni su češći u listovima nego u cvetovima. 
Glavnina biljnih flavonoida nije direktno obojena, apsorbuju ultraljubičasti deo spektra, i nevidljivi su u vidljivom delu spektra, ali su važni kao kopigmenti antocijaninima (Harborne i Turner, 1984). Najčešći bezbojni flavonoidi su flavonoli i flavoni. Kod predstavnika familije Lamiaceae poznati su sledeći flavonoidi: flavoni, flavonoli, flavanoni, dihidroflavonoli i halkoni (Marin, 1995). Takođe, kod Origanum vulgare, utvrđeno je prisustvo i jednog aurona (Barberán, 1986). Halkoni su veoma retki u ovoj familiji (Tomimori i sar., 1984, 1985; Messana i sar., 1990)

Flavoni su glavna grupa bezbojnih flavonoida prisutnih u familiji Lamiaceae. Veoma su česti i aglikoni i glikozidi flavonoida (67-75\%) (Marin, 1995). Od ukupno 147 flavonoida koji su identifikovani u familiji Lamiaceae, oko 60\% su flavoni (TomásBarberán i Gil, 1992).

Verovatno najčešći flavonski aglikon u ovoj familiji je apigenin kao i odgovarajući metil etri (acetatin, hrizoeriol, diosmetin, itd). Jedna od prvih studija flavona listova i petala kod Lamiaceae, navodi luteolin kao glavni flavon kod rodova Teucrium, Mentha, Lycopus, Salvia, Thymus, Stachys i Lavandula (Hörhammer i Wagner, 1962).

Neki veoma interesantni i retki flavoni su, izgleda, prisutni kod samo malog broja rodova familije Lamiaceae. Tako su baikalein i skutelarein locirani u korenu i listovima vrsta roda Scutellaria, dok kod nekih vrsta Scutellaria javlju kao 7glukoronidi. Kod Satureja douglasii je otkriven ksantomikrol. Nakon ovih rezultata Harborne (1967) je saopštio da je ostalo da se utvrdi prisustvo još velikog braoja retkih i zanimljivih flavona u ovoj familiji. I zaista, brojni visoko metoksiolovani flavoni su utvrđeni kod raznih vrsta Lamiaceae. Salvigenin kod Salvia virgata, sideritoflavon (5,3',4'-trihidroksi-6,7,8-trimetoksiflavon) kod Sideritis leucanta, timonin kod Tymus vulgaris, timusin kod Thymus membranaceus (Ferreres i sar., 1985; Barberán, 1986), 5,6-dihidroksi-7-8,3',4'-tetrametoksiflavon kod Mentha piperita (Jullien i sar., 1984), 8metoksicirzilineol kod Sideritis mugronensis (Rodriguez 1977). Nepetin (5,7,3',4'tetrahidroksi-6-metoksilflavon) je prvo detektovan kod Nepeta, a potom i kod rugih rodova (Rosmarinus i Salvia). Flavoni sa oxigenovanim C-6 i C-8 mogu se smatrati karakterističnim za familiju Lamiaceae. 
Sideritoflavon je utvrđen i kod drugih rodova, na primer Thymus, Mentha i Stachys, kao i salvigenin kod Thymus, Rosmarinus, Ballota, Coleus, itd (TomásBarberán i Wollenweber, 1990).

U tribusu Menthae (=Saturejeae) prisutne su sledeće komponente: timonin (5,6,4'-trihidroksi-7,8,3'-trimetoksiflavon), timusin (5,6,4'-trihidroksi-7,8dimetoksiflavon), pebrelin (5,6-dihidroksi-7,8,4'-trimetoksiflavon), ladanein (5,6dihidroksi-7,4'-dimetoksiflavon), 5,6-dihidroksi-7,8,3',4'-tetrametoksiflavon i 5,6dihidroksi-7,3',4'-trimetoksiflavon. Ova se jedinjenja kod Micromeria, Satureja i srodnih vrsta uglavnom nalaze na površini listova rastvorena u terpenoidnom matriksu (Tomás-Barberán i sar., 1988b; Tomás-Barberán i Gil, 1992).

Posmatrajući flavone može se zaključiti da su kod Lamiaceae uglavnom povezani sa šećerima (glikozidi). Najčešća veza između različitih šećera sa flavonskim aglikonima je na 7. mestu. Najčešća komponente su mono-O-glikozidi (glikozidi, glukuronidi i retko ksilozidi, ramnozidi arabinozidi i galaktozidi). Od diglikozida, rutinozidi, soforozidi i alozil (1,2) glikozid (Tomás-Barberán i Gil, 1992) su najčešći.

Flavon C-glikozidi su manje česti u ovoj familiji. Apigenin 6,8-diC-glikozid (vicenin-2) je pronađen kod Teucrium, Origanum i nekih srodnih rodova (Husain i sar., 1982). Viteksin je identifikovan kod Majorana hortensis, luteolin C-glikozid (orienin) kod Phlomis, Ajuga, Dracocephalum i Majorana i dva hrizin C-glikozida kod Scutellaria (Takagi i sar., 1981).

U literaturi se navodi da flavonol aglikoni čine oko $16 \%$, a flavonol glikozidi oko 10\% ukupnih flavonoida kod familije Lamiaceae (Tomás-Barberán i Gil, 1992). Međutim, ispitivanja vrta skoro 50 rodova su pokazala da flavonol aglikoni nisu zastupljeni u toj meri. Utvrđeno je prisustvo kaempferola kod Origanum vulgare, izokampferida, retusina ajanina i kumatakenina kod Salivia glutinosa (Barberán, 1986), kao i purpurascenina kod Pogostemon (Patwardhan i Gupta, 1981), itd.

Kod vrsta familije Lamiaceae pronađeno je nekoliko flavonol glikozida, kvercetin 3-O-glikozid i 3-O-galaktozid kod Glechoma hederacea (Barberán, 1986), kao i još neki derivati kvercetina kod drugih vrsta (Harborne, 1967).

Flavanoni se, takođe, pojavljuju kod familije Lamiaceae u formi aglikona (oko $20 \%$ ) i glikozida (oko 13\%). 
Flavanon aglikoni su pronađeni kod različitih rodova Lamiaceae, naringenin kod Micromeria i srodnih rodova (Bellino i sar., 1980), eriodiktol kod Mentha spp. (Burzanska-Hermann, 1978; Marin, 1989).

Kod vrsta Micromeria, Acinos i Calamintha utvrđeno je prisustvo flavanon glikozida kao što je neoponcirin (Bellino i sar., 1980), dok su kod Mentha i Sutellaria spp. nađeni razni eriodiktiol glikozidi. Takođe, kod Mentha spp. i Hyssopus je utvrđeno prisustvo hesperetin glikozida (Barberán, 1986).

Dihidro flavonoli i halkoni su retki kod familije Lamiaceae, i kao aglikoni i kao glikozidi. Njihovo prisustvo je utvrđeno kod malog broja vrsta (Barberán, 1986; Venturella i sar., 1980)

$\mathrm{Na}$ osnovu veoma obimne literature pokazalo se da su flavonoidi, kao taksonomski markeri, pokazali najbolje rezultate na nivou roda (Marin, 2003), ali se koriste i kod viših i kod nižih nivoa klasifikacije.

Određena populaciona varijabilnost flavonoida je utvrđena kod Mentha (Marin, 1989), ali glavne komponente su uvek bile iste u okviru jedne vrste. Kod Sideritis leucantha je praćena sezonska donamika slobodnih flavonski aglikona i utvrđeno je da se njihov sastav tokom sezone ne menja, već samo njihova količina, te da se oni mogu koristiti kao pouzdani taksonomski karakteri (Barberán i sar., 1985).

Kod vrste Thymus striatus primećena je varijabilnost u dlakavosti, veličini listova i čašice (Menitsky, 1973). Analizom površinskih flavonoida populacija ove rvrste iz crne Gore, utvrđeno je da ne postoji značajna razlika u flavonoidnim profilima između populacija, kako različitih po ovim morfološkim karakterima, tako i po geografskoj distribuciji (Marin i sar., 2005). Kod većine ispitivanih populacija ksantomikrol je bio glavna komponenta, a kod dva uzorka kod kojih je bio dominantan javljao se u veoma visokom procentu (Marin i sar., 2005).

Horwath i sar. (2008) su proučavali varijabilnost u sastavu površinskih falvonoida 71 populacije vrsta Thymus hyemalis i Th. baeticus, kao i njihovih putativnih hibrida sa područja Andaluzije u Španiji, i utvrdili prisustvo 22 flavona, 5 flavanona, 2 dihidrofalvonola, 1 flavonol i dve nedeterminisane komponente. Većina površinskih falvona je imala 3',4'-oxigenovan prsten za razliku od taksona sa Balkana gde je dominirala 4'-oksigenacija B-prstena tj. derivati apigenina (Marin i sar., 2003). Ova značajna razlika ukazuje da je geografska izolacija dovela do genetičke divergencije 
ovih taksona tokom vremena, što za posledicu ima da su vrste ustalile enzimsku konsitituciju koja favorizuje određene flavonoide.

Primećena geografska varijabilnost i distribucija flavonoida ukazuje na značaj ovih sekundarnih metabolita pri adaptaciji biljaka na lokalne uslove u kojima žive (Tomás-Barberán i Gil, 1992), tj. da jedinke Thymus iz različitih regiona su razvile specifične fiziološke adaptacije na uslove sredine u kojima žive (Horwath i sar., 2008).

Kod mnogih rodova familije Lamiaceae je utvrđeno postojanje hibrida, a naročito su česti kod Thymus, Mentha, Stachys, Sideritis, itd. Postoje čak i hibridi vrsta različitih rodova, kao na primer Micromeria i Calamintha (Šilić, 1979). Upravo česta hibridizacija i odsustvo morfoloških karaktera po kojima bi se hibridi razlikovali je uzrok mnogih teškoća u taksonomiji ove familije, s toga je moguće tražiti odgovore primenom biohemijske taksonomije.

Analizom sastava vakuolarnih i površinskih flavonoida, primenom HPLC i TLC, utvrđeno je postojanje hibrida između Sideritis incana i S. angustifolia (Tomas-Lorente i sar., 1989). Hibridi su imali flavonoidni profil karakterističan za roditeljske vrste. Takođe, utvrđena je i korelacija između prisustva žlezda i površinskih flavonoida kod proučavanih taksona. U drugoj studiji pokazano je prisustvo hibrida između simpatričkih vrsta Sideritis bourgaeana i S. serrata HPLC analizom površinskih i vakuolarnih flavonoida. Hibridi su pokazali prisustvo komponenti koje su karakteristične za roditeljske vrste (Ferreres i sar., 1989). Navedeni rezultati su pokazali i da su površinski flavonoidi pouzdaniji karakter od vakuolarnih flavonoidnih glikozida za utvrđivanje hibridizacije. Ovo je navelo na zaključak da površinski flavonoidi mogu biti veoma korisni pri rešavanju taksonomskih problema.

Nekoliko ekstenzivnih studija flavonoida ukazuje da su ovi sekundarni metaboliti kod cvetnica najefikasniji u proučavanju taksonomije na nivou roda i unutar roda (Markham i sar., 1970; Swain, 1975; Harborne, 1975, 1977, 1984; Greger, 1978; Gurni i Kubitzki, 1981; Young i Sterner, 1981).

I rodovi u okviru familije Lamiaceae su ekstenzivno proučeni sa aspekta flavonoida. Kod roda Origanum i srodnih rodova, pokazano je da se na osnovu prisustva ili odsustva derivata luteolina, hrizoeriola, apigenina i skutelareina ovaj rod može podeliti u šest grupa. Ovo podržava podelu roda na dve sekcije, Origanum i Majorana (Fernandes i Heywood, 1972; Ietswaart, 1980). Međutim, ovi rezultati niti 
podržavaju izdvajanje Origanum amanum u zasebnu sekciju, kako je predložio Ietswaart (1980), niti podelu preostalih vrsta, sekcija Amaracus, u posebnu sekciju. Takođe, pokazano je da da prisustvo apigenin 6,8-di-C- glikozida (vicenin-2) ne zavisi od geografskog položaja, već je prisutan samo kod vrsta iz sekcije Majorana, tako da može predstavljati važan taksonomski karakter na nivou sekcija kor roda Origanum. Vicenin-2 se pojavljuje i kod vrsta rodova Hyssopus i Thymus ukazujući na blisku srodnost ova tri roda $\mathrm{u}$ okviru tribusa Mentheae.

Rod Thymus predstavlja još jedan zanimljiv rod sa aspekta hemotaksonomije. Taksonomski je veoma težak zbog velikog polimorfizma mnogih vrsta, i predloženo je nekoliko reklasifikacija (Jalas, 1972; Morales, 1985). Analizom površinski flavonoida 23 vrste sa Iberijskog poluostrva, registrovano je prisustvo 16 slobodnih flavonskih aglikona (Hernándes i sar., 1987). Prikazani rezultati podržavaju podelu roda Thymus na dve dobro definisane grupe, koje se mogu tretirati i kao podrodovi, ali je potrebna i potvrda morfoloških karaktera (Hernándes i sar., 1987). Uopšteno govoreći, sastav površinskih flavonoida proučavanih vrsta, podržava taksonomsku reviziju roda Thymus datu na osnovu morfoloških karaktera (Morales, 1985).

Rezultati proučavanja površinskih flavonoida 40 vrsta i infraspecijskih taksona sa područja Makedonije pokazala su da se ove vrste mogu svrstati u dva flavonoidna profila (Marin i sar., 2003). Prvoj grupi pripadaju vrste sa visokim do umerenim sadržajem poršinskih flavonoida koji uključuju flavanone eriodiktiol i naringenin, kao i jedinjenja sa 5,6-dihidroksi-7,8-dimetoksi-, a naročito, 5,6-dihidroksi-7-metoksi substitucijam u A prstenu, pri čemu je 5,6-dihidroksi-7,3',4'-trimetoksiflavon najprisutnija komponenta u najvećem broju slučajeva. Ggrupa 2 sadrži vrste sa malom do umerenom količinom površinskih flavonoida, i u kojoj je osim eriodiktiola i naringenina prisutani i metoksilovani flavanoni, kao na primer izosakuranetin. 5,6dihidroksi-7,3',4'-trimetoksiflavon i drugi flavoni sa 5,6-dihidroksi-7-metoksi A prstenom uglavnom nisu prisutni u ovoj grupi, s izuzetkom ladaneina koji se kod nekih predstavnika javlja u tragovima. Ove grupe, donekle, odgovaraju podeli na sekcije koje je dao Menitsky (1973). Flavonoidnom profilu grupe 1 pripada pet od osam proučavanih vrsta iz sekcije Marginati, podsekcija Marginati i pet od sedam ispitivanih vrsta sekcija Marginati, podsekcija Verticillati. Flavonoidni profil grupe 2 javlja se kod dve vrste iz sekcije Pseudothymbra, dok je kod preostale tri proučavane vrste sadržaj 
flavonoida izuzetno nizak, te se njihov sastav ne može sa sigurnošću odrediti, kod dve vrste iz sekcije Serpyllum, podsekcija Isolepides, i kod tri od osam proučavanih vrsta iz sekcije Marginati, podsekcija Marginati, Th. jankae, Th. albanus i Th. balcanus.

Podela sekcije Marginati, podsekcija Marginati na dva flavonoidna profila je veoma neočekivana, pošto sve proučavane vrste pripadaju agregatu Th. praecox, i neki ih autori smatraju jednom vrstom, međutim u ovoj studiji se pokazlo da Th. longicaulis, Th. rohlenae i Th. moesiacus pripadaju grupi 1, a da Th. jankae, Th. albanus i Th. balcanus pripadaju grupi 2. Ipak, iako obe grupe imaju veoma sličan habitus, postoje morfološke razlike među njima (Marin i sar., 2003). Kod vrsta iz Th. paraecox agregata sa Iberijskog poluostrva utvrđeno je prisustvo različitih komponenti (Hernándes i sar., 1987) u odnosu na one iz Makedonije, ali bi se oni mogli svrstati u flavonoidini profil 2. Kod makedonskih vrsta ovog agregata primećena je razlika ne samo između različitih vrsta ovog agregata, već i među podvrstama i varijetetima iste vrste (Marin i sar., 2003). Kod vrste Th. pulegioides takođe je postojala značajna razlika između uzoraka sa Iberijskog i Balkanskog poluostrva. Prema rezultatima Hernándes i sar. (1987) Th. pulegioides sa Iberijskog poluostrva je, za razliku od makedonskih populacija, pripadao bi profilu grupe 1, a ovi profilu grupe 2. Ovo ukazuje na veoma visoku populacionu varijabilnost ove vrste (Marin i sar., 2003).

Najveći broj vrsta iz podsekcije Verticillati pokazuje flavonoidni profil 1, s time da su kod najvećeg broja vrsta iz ove podsekcije prisutna jedinjeja 5,6,4'-trihidroksi7,3'-dimetoksiflavon i timusin, koji nisu utvrđeni ni kod jedne druge ispitivane vrste iz podsekcije Marginati, osim Th. oehmianus koji sadržao 5,6,4'-trihidroksi-7,3'dimetoksiflavon kao glavnu komponentu. Menitsky (1973) razlikuje dva agregata u ovoj podsekciji, agregate Th. marschlianus i Th. glabrescens, među kojima su morfološke razlike neznantne tako da su tu mnoga takosonomska pitanja otvorena (Marin i sar., 2003).

Iz sekcije Pseudothymbra Marin i sar. (2003) su uključili sedam vrsta i u svima, osim Th. karadzicensis i Th. paranassicus, je detektovana veoma mala količina površinskih flavonoida koji nisu mogli sa sigurnošću biti određeni. Flavonoidni profili kod Th. karadzicensis i Th. paranassicus su bili slični, karakteristični po prisustvu flavonoida sa 5-hidroksi-6,7,8-trimetoksi supstitucijama u A prstenu i potpunom 
odsustvu sa drukčijim A prstenom. Flavanoni eriodiktol i naringenin su, takođe, izgledna otsutni kod ovih taksona.

Kod dve vrste, Th. pseudoatticus i Th. comptus iz sekcije Serpyllum, podsekcija Isolepides, utvrđen je flavonoidni profil sličan vrstama iz podsekcije Pseudothymbra, s time da su kod Th. pseudoatticus bili prisutni i flavoni sa 5-hidroksi-6,7-metoksi supstitucijama u A prstenu, a eriodiktiol i naringenin su bili prisutni kod obe vrste. Takođe, postojale su i određene sličnosti sa flavonoidnim profilima Th. jankae, Th. albanus i Th. balcanus iz sekcije Marginati, podsekcija Marginati (Marin i sar., 2003).

Iz svega iznetog Marin i sar. (2003) smatraju da je infargenerička klasifikacija od strane Menitskog (1973) bolje podržana rezultatima dobijenim analizom površinskih flavonoida nego ona koju je predložio Jalas (1972).

U nekim slučajevima površinski flavonoidi mogu se koristiti pri odluci kom rodu neki takson pripada. Tako su flavonoidi Thymbra capitata (L.) Griseb. proučavanu sa hemotaksonomskog aspekta (Barberán i sar., 1986). Do tada se smatralo da ova vrsta pripada rodu Thymus, Thymus capitatus (L) Hoffmann i Link, ili Corydothymus, Corydothymus capitatus (L) Reichenb. fill. Ovi rezultati u kombinaciji sa prethodnim istraživanjima su ustanovili prisustvo nekih zajedničkih flavonoida sa Thymbra capitata i time sugerisali da ova vrsta pripadad rodu Thymbra (Barberán i sar., 1986).

Flavonoidi mogu biti korisni taksonomski markeri i pri određivanju granica između blisko srodnih rodova, kao na primer Micromeria, Calamintha, Acinos, Satureja i Clinopodium (Marin 1996). Thomas-Barberán i sar. (1988) su pokazali da distribucija 5,6-dihidroksiflavona, koji su izuzetno lipofilni, može biti značajna za razlikovanje blisko srodnih rodova. Takođe, pokazali su da je prisustvo ovih jedinjenja vezano samo za neke rodove podfamilije Nepetoideae i to uglavnom iz tribusa Mentheae. Površinski flavaonoidi su kod Satureja veoma prikladni hemotaksonomski karakteri na nivou sekcija (Thomas-Barberán i sar., 1991). Uz to, poručavanja vakuolarnih flavonoida kod Micromeria su pokazala neophodnost podele ovog roda na sekcije i potvrdila Boisserovu klasifikaciju (1879) na sekcije Pseudomelissa i Eumicromeria.

Flavonoidi su proučavani i kao taksonomski karakteri i na nivo tribusa, podfamilija i familija kod viših biljaka (Harborne, 1984). Ova grupa jedinjenja je takođe bila analizirana i unutar fmilije Lamiaceae kao i odnosa ove familije sa srodnim familijama (Verbenaceae, Scrophulariaceae, Boraginaceae, itd). U radovima koji se 
bave proučavanjem flavonoida kao taksonomskih karaktera u okviru familije Lamiaceae, pokazano je da rodovi iz tribusa Mentheae (Micromeria, Acinos, Calamintha, Origanum, Thymus, Mentha i Satureja) imaju sličan sastav, naročito, površinskih flavonoida. Vrste iz ovih rodova akumuliraju 5,6-dihidroksi-7,8dimetoksiflavone koji nisu prisutni u ostalim rodovima iz familije Lamiaceae (ThomasBarberán i sar., 1988; Thomas-Barberán i Gill., 1992). Ove se komponente, dakle, mogu smatrati taksonomskim karakterima na nivou tribusa, ali treba napomenuti da nisu pronađene kod roda Clinopodium koji takođe pripada ovom tribusu.

Takođe, rezultati proučavanja flavonoidinih glikozida su pokazali da su rodovi Galeopsis, Leonurus, Ballota, Anisomeles, Marubium, Phlomis, Stachys, Sideritis i Pogostemon blisko srodni (Thomas-Barberán i Gill., 1992). Vrste iz ovih rodova sintetišu ili flavonoid p-kumaroil-glikozid ili 8-hidroksiflavon 7-alozil-glikozid, koji nisu prisutni kod ostalih rodova iz familije Lamiaceae.

\subsubsection{Biološka aktivnost sekundarnih metabolita}

Vrste roda Thymus su veoma značajne i dobro poznate kao lekovite i aromatične biljke, u upotrebi skoro u svim regionima gde rastu. Njihova etarska ulja se dobijaju industrijski putem destilacije. Takođe se koriste i kao ukrasne biljke i dobijen je veliki broj sorti.

Fadli i sar. (2012) su ispitivali antibakterijsku aktivnost etarskih ulja vrsta $T h$. maroccanus i Th. broussonetii na bakterijske sojeve otporne na antibiotike i pokazali da etarska ulja obe vrste imaju antibakterijsku aktivnost koja se može povezati sa visokim koncentracijama karvakrola. Antibakterijska aktivnost etarskih ulja deset biljnih vrsta je ispitivana i na bakterijske sojeve patogene za čoveka $\mathrm{i}$ tom prilikom je pokazano da najjaču aktivnost imaju etarska ulja Th. vulgaris i Origanum vulgare (Soković i sar., 2007), odnosno da su komponente sa najvećom antibakterijskom aktivnošću mentol, timol, a naročito karvakrol. Ovi autori takođe navode da je antibakterijska aktivnost jača protiv Gram-pozitivnih nego Gram-negativnih bakterija. Inhibitorna aktivnos protiv Gram-pozitivnih bakterija, kao i antifungalna aktivnost, je pokazana i kod etarskog ulja vrste Th. algeriensis kod kojeg su dominirale ne fenolne komponente (Zouari i sar., 2011). 
Antifungalna aktivnos etarskih ulja Cymbopogon citratus, Ocimum gratissimum i Thymus vulgaris ispitivana je na vrsti Penicillium expansum (Nguefack i sar., 2012) pokazano je da najveće dejstvo ima etarsko ulje Ocimum gratissimum kod kojeg je glavna komponenta timol. Takođe je primećeno da je antifungalni efekat etarskog ulja Th. vulgaris manji nego onaj kod Cymbopogon citratus, mada je glavna komponenta etarskog ulja ove vrste citral (neral i geranial), što objašnjavaju prisustvom borneola i bornil-acetata u etarskom ulju kod Th. vulgaris što samnjuje aktivnost. Antifungalna aktivnost je ispitivana i kod Th. zygis subsp. sylvestris, pri čemu je utvrđeno postojanje hemotipovi, kao i da je karvakrolni hemotip imao najjaču antifungalnu aktivnost na dermatofitne sojeve (Gonçalves i sar., 2010). Pri tretmanu gljivičnie infekcije izazvane dermatomicetama kod laboratorijskih pacova etarsko ulje Th. vulgaris, a thimol naročito, su pokazali visoku antifungalnnu i terapeutsku aktivnost (Soković i sar., 2008). Soković i sar. (2009) su poređenjem antifungalne aktivnosti etarskih ulja vrsta Th. tosevii, Th. vulgaris, Mentha spicata i M. piperita, konstatovali da je ova mnogo izraženija kod etarskih ulja vrsta roda Thymus, odnosno da je u zavisnosti od koncentracije fenolnih komponenti.

Etarska ulja imaju i antioksidativnu aktivnost za koju su takođe odgovorne fenolne komponente, timol i karvakrol. Ispitivajem antioksidativne aktivnosti etarskog ulja Th. pulegioides metodom gašenja stabilnih slobodnih 2,2-difenil-1-pikrilhidrazil (DPPH) radikala i ABTS metodom, utvrđeno je da hemotipovi sa visokom koncentracijom timola i/ili karvakrola imaju jače dejstvo (Ložienė i sar., 2007). Visoka koncentracija karvakrola u etarskom ulju Th. caramanicus, takođe, je uslovljavala visoki DPPH inhibitorni potencijal (Safaei-Ghomi i sar., 2009).

Navodni terapeutski efekti mnogih narodnihg lekova mogu biti pripisani prisustvu flavonoida, čiji je farmakološki efekat u vezi sa njihovom inhibicijom odeđenih enzima i njihove antioksidativne aktivnosti (Marin, 2003). Pokazano je da ekstrakti Scutellaria, Mentha, Nepeta, Origanum i Thymus imaju antibakterijaska dejstva. Utvrđeno je da flavonoid aglikoni cirsimaritin, baikalein i drugi imaju značajna antibakterijska dejstva (Barberán, 1986). Antibakterijaska aktivnost je utvrđena za metanolni ekstrakt Marrubium globosum ssp. libanoticum, a od čistih komponenti, kvercetin 3-O- $\beta$-D-rutinozid, verbaskozid i naringenin 7-O- $\beta$-D-glucozid su imali najveću antibakterijsku aktivnost (Rigano i sar., 2007). 
Antiviralna aktivnost flavonida je razmatrana u studiji Wang i sar. (1998). Neki od virusa na koje flavonoidi imaju uticaj su herpes samplex virus, respiratorni sincitijalni virus, virus parainfluence $\mathrm{i}$ adenovirus. Kvercetin je pokazao da ima $\mathrm{i}$ antinfekcijska i antireplikacijska svojstva (Kaul i sar., 1985). Abad i sar. (1997) su analizirali etanolne ekstrakte dvanaest biljnih vrsta i, takođe, utvrdili da neki od njih imaju inhibitorno dejstvo na herpes simplex virus.

Barberán (1986) je u analizi flavonoida familije Lamiaceae dao i pregled do tada poznatih podataka o antiinflamatornoj aktivnosti flavonoida iz ove failije. Navedeni su rodovi Stachys, Mosla, Sideritis i Nepeta, čije se vrste koriste u te svrhe u narodnoj medicini. Kod ekstrakata tri vrste roda Salvia utvvrđena je antiinflamatorna aktivnost za koju se smatra da su odgovorni flavonoidi (Çadirci i sar., 2012).

Antioksidativna aktivnost je narolčito interesantna $\mathrm{u}$ industriji hrane zbog usporavanja oksidativne degradacije lipida. Ekstrakti Origanum mogu se koristiti kao antioksidanti s obzirom da sadrže značajnu količinu flavonoida . Luteolin, siderito flavon i 8-metoksicirsineol, mogu se smatrati veoma aktivnim antiosidantima hrane (Marin, 2003). Marinova i Yanishlieva (1996) su analizirale antioksidativnu aktivnost ekstrakta iz odabranih vrsta familije Lamiacceae i utvrdile da, od ispitivanih vrsta, etanolni ekstrakt Satureja hortensis ima najveću aktikvnost. Natioksidativna aktivnost je utvrđena i kod vodenog ekstrakta vrsta Scutellaria immaculata i S. ramosissima, s time da izolovani skutelarin i ma jeaču aktivnosto od drugih prisutnih flavonoida (Mamadalieva i sar., 2011). Pri in vitro ispitivanju antioksidativne aktivnosti ekstrakata 18 vrsta iz familije Lamiaceae, najjači efekat imali su polarni ekstrakti Lycopus europaeus, Melissa officinalis, Origanum vulgare subsp. virens and Lavandula latifolia (López i sar, 2007).

Sve ovo pokazuje da sekundarni metaboliti imaju široki spektar delovanja koja su u velikoj meri od koristi za čoveka. Od sastava etarskih ulja i od flavonoidnog profila zavisi i spektar biološke aktivnosti, tako da je njihovo poznavanje veoma bitno pri izboru određene biljne vrste za upotrebu u narodnoj i oficijelnoj medicini. 


\subsubsection{Kariološka, palinološka i mikromorfološka istraživanja vrsta roda Thymus}

Hromozomi su kod roda Thymus veoma sitni (Morales, 2002). Veličina im se kreće od 1 do $2 \mu \mathrm{m}$ i pod svetlosnim mikroskopom vide se kao tačke. Poznati su sledeći brojevi hromozoma $2 n=24,26,28,30,32,42,48,50,52,54,56,58,60,84$ i 90, koji odgovaraju diploidnom, tetraploidnom i heksaploidnom nivou. Od osnovnog broja $\mathrm{x}=7$, verovatno su nastali sekundarni osnovni brojevi $x=14$ i $x=15$. Najčešći brojevi hromozoma su $2 n=28,30,56$ i 60 . Aneuploidi zauzimaju važno mesto u evoluciji ovog roda i odgovorni su za ostale brojeve.

Polenova zrna u okviru ovoga roda su veoma homogena, uglavnom heksakolpatna i sa supraretikularnom ornamentacijom. Veličina im varira između $21-$ $46 \mu \mathrm{m}$ i P/E između 0,9 i 1,3 (Morales, 1986).

Kod vrsta iz Fmilije Lamiaceae su rađena i ispitivanja mikromorfoloških karaktera, kao što su izgled i građa žlezdanih i nežlezdanih trihoma, kao i skulpturacija orašica.

Kod familije Lamiaceae taksonomski značaj nekih karktera orašica opisan je kod više rodova (Marin, 1996). Kod tribusa Menthae, ispitivanjem vrsta 57 rodova, utvrđeno je značajno variranje u obliku, morfologiji abscisionog ožiljka, distribuciji trihoma i površinskoj skulpturiranosti orašica (Moon i sar., 2009a), Primećeno je pet tipova površine orašica, i ove karakterisitke se mogu korikstiti za filogenetske analize na nivou roda. Özkan i sar. (2009) su ispitivali orašice vrsta roda Salvia iz Turske i upoređivanjem oblika, veličine, boje i površinske skulpturiranosti orašica došli do zaključka da su ovi karkter korisni pri razlikovanju grupa vrsta, kao i samih vrsta i podvrsta. Takođe, kod vrsta roda Nepeta (Kaya i Dirmenci, 2008) i vrsta roda Stachys (Salmaki i sar., ,2008) mikromorfološke karakteristike orašica, naročito spoljašnaj skulpturiranost, mogu poslužiti kao taksonomski karkteri. Analizom površinskih karaktera orašica kod tribusa Westringieae utvrđeni su, dosta dobro, filogenetski odnosi (Guerin, 2005). Kod vrsta iz roda Thymus analizirane su vrste Th. pulegioides, iz sekcije Serpyllum, i Th. zygis, iz sekcije Thymus, kao i jedna vrsta ovog roda koja nije bila u potpunosti determinisana (Marin, 1996). Merikarpi kod vrste Th. pulegioides i Th. zygis su imali različiti tip skulpturiranost. Površina orašica kod Th. pulegioides je nepravilno 
naborana, bez jasnih struktura. Orašice Th. zygis su imale ovalna jasno omeđena polja sa talasastim marginama. Ornamentisanost orašica kod nepotpuno određene vrste je bilo veoma slično vrsti Th. zygis. Međutim, Marin (1996) smatra da bi za sigurnije zaključke o značaju ornamentacije orašica u infrageneričkoj klasifikaciji ovog roda trebalo izvršiti šire uzorkovanje.

Moon i sar. (2009b) su utvrdili prisustvo dve grupe trihoma na listovima $u$ okviru tribusa Menthae, nežlezdane i žlezdane. Kod nežlendanih su razlikovali unicelularne, uniserijatne i razgranate trihome, dok sus od žlezdanih kod ovog tribusa opisali kapitatne, pilatne i peltatne trihome. Ovi autori smatraju da su mikromorfološki karaktreri listova sa taksonomskog aspekta ograničeni na subtribalni nivo, i da za jasniju sliku treba koristiti veći broj karaktera. Kod vrsta Thymus maly (Marin i sar., 2008) i Th. glabrescens (Dajic Stevanovic i sar., 2008) su takođe opisane glandularne i peltatne trihome, kao i negladularne trihome.

\subsubsection{Molekularna istraživanja}

Za dve decenije od kako je opisana, PCR (Polymerase Chain Reaction) je postala skoro sinonim za istraživanja u molekularnoj biologiji. Najveći doprinos PCR metode molekularnoj sistematici je brza amplifikacija pojedinačnih regiona DNK, što omogućuje sekvenciranje redosleda nukleotida.

U početku primene PCR metoda za filogenetske studije kod biljaka najviše se koristio hloroplastni genom, a kasnije su počele da se koriste i nuklearne sekvence DNK (kao na primer ITS i 18S rDNK). U zasvisnosti od tksonomskog nivoa koji se proučava, koriste se različiti hloroplastni, nuklearni ili mitohondrijalni regioni DNK (Soltis i Soltis, 2000).

Za filogenetska ispitivanja neki od njačešće korišćenih plastidnih markera su $t r n \mathrm{~L}-t r n \mathrm{~F}, a t p \mathrm{~B}-r b c \mathrm{~L}, n d h F, m a t \mathrm{~K}$ i $r p s 16$. Za filogenetsku analizu i radijaciju u flori Kapske oblasti 73 vrste roda Moraea (Iridaceae) korišćeni su markeri $r b c \mathrm{~L}$ egzon, $t r n \mathrm{~L}$ intron, trnL-trnF intergenski spejser i rps16 intron (Goldblatt i sar., 2002). Pri ispitivanju filogenetskih odnosa unutar familije Fabaceae Sulaiman i sar. (2003) su koristili $r b c \mathrm{~L}$ dok su Chase i sar. (1993) analizirali filogeniju semenjača na osnovu $r b c \mathrm{~L}$. 
Od nuklearnih molekularnih markera najviše se koriste ITS, 26S rDNK i $18 \mathrm{~S}$ rDNK. 26S rDNK i $18 \mathrm{~S}$ rDNK su pogodni markeri za ispitivanje filogenija na višem taksonomskom nivou (Kuzoff i sar., 1998). U redu Cornales je utvrđeno postojanje osam dobro podržanih klada, i to: Cornus, Alangium, nyssoide (Nyssa, Davidia, and Camptotheca), mastixioide (Mastixia and Diplopanax), Hydrangeaceae, Loasaceae, Grubbia-Curtisia, and Hydrostachys (Fan i Qiu-Yun Xiang, 2003). ITS se uglavnom koristi za proučavanje filogenija na nivou rod i vrsta. Tako je, na primer, analizirano monofiletsko poreklo i filogenija roda Monandra (Prather i sar., 2002) i divergencija u okviru roda Cuminia (Ruiz i sar., 2001).

AFLP markeri (Amplified fragment length polymorphism) su za mnoge taksonome prvi izbor pri odabiru molekularnih markera za rešavanje filogenije na nivou rodova i vrsta u slučaju kada su klade imale radijaciju u bliskoj evolutivnoj prošlosti (na pr. Dixon i sar., 2009; Moghaddam i sar., 2009; Rahimmalek i sar., 2011).

U poslednje vreme pojavio se veliki broj studija koje se bave molekularnom sistematikom podfamilije Nepetoideae, sa fokusom na Ocimeae (Paton i sar., 2004), a naročito Mentheae. Većina se bavila određenim rodovima, kao npr. Bystropogon (Trusty i sar., 2004, 2005), Conradina (Edwards i sar., 2006, 2008a,b), Mentha (Bunsawat i sar., 2004), Micromeria (Bräuchler i sar., 2005), Minthostachys (SchmidtLebuhn, 2007, 2008), Monarda (Prather i sar., 2002) i Salvia (Walker i sar., 2004; Walker and Sytsma, 2007), dok su neki bili usredsređeni na na subtribalni nivo (Bräuchler et al, 2010). Postoje brojne studije koje se bave hemijskim polimorfizmom i biološkim interakcijama kod roda Thymus (npr. Horwath i sar., 2008; Rota i sar., 2008; Maksimović i sar., 2008b), ali jako mali broj istraživanja je vršen na molekularnom nivou u okviru ovog roda, i to isklučivo na jednoj vrsti (Echeverrigaray i sar., 2001; Trindade i sar., 2008; Trindade i sar., 2009).

\subsection{Opis izabranih taksona roda Thymus}

Thymus balcanus Borb. (Slika 1.4) Stabljike dugačke, puze po zemlji, na krajevima se završavaju sterilnom rozetom listova. Cvetne grane se razvijaju u nizovima duž položenog stabla. Listovi debeli, kožasti eliptični ili loptičasti, 2 do 3 put duži od širine, dugački oko10 mm, sa razvijenom lisno drškom, na licu goli ili pokriveni 
proređenim dugačkim dlakama, bočni nervi na naličiju liske jako istaknuti, debeli, jako lučno savijeni, najčešće se ne spajaju u jedan obodni nerv. Cvetovi složeni na vrhu grana u okruglaste, ređe izdužene cvasti. Cveta od maja do avgusta. Javlja se na kamenjarima, na krečnjaku i serpentinu u planinskom i subalpijskom pojasu. Endemit je Balkanskog poluostrva. Prema Flori Evrope Th. balcanus je opisan kao Th. praecox subsp. polytrichus.

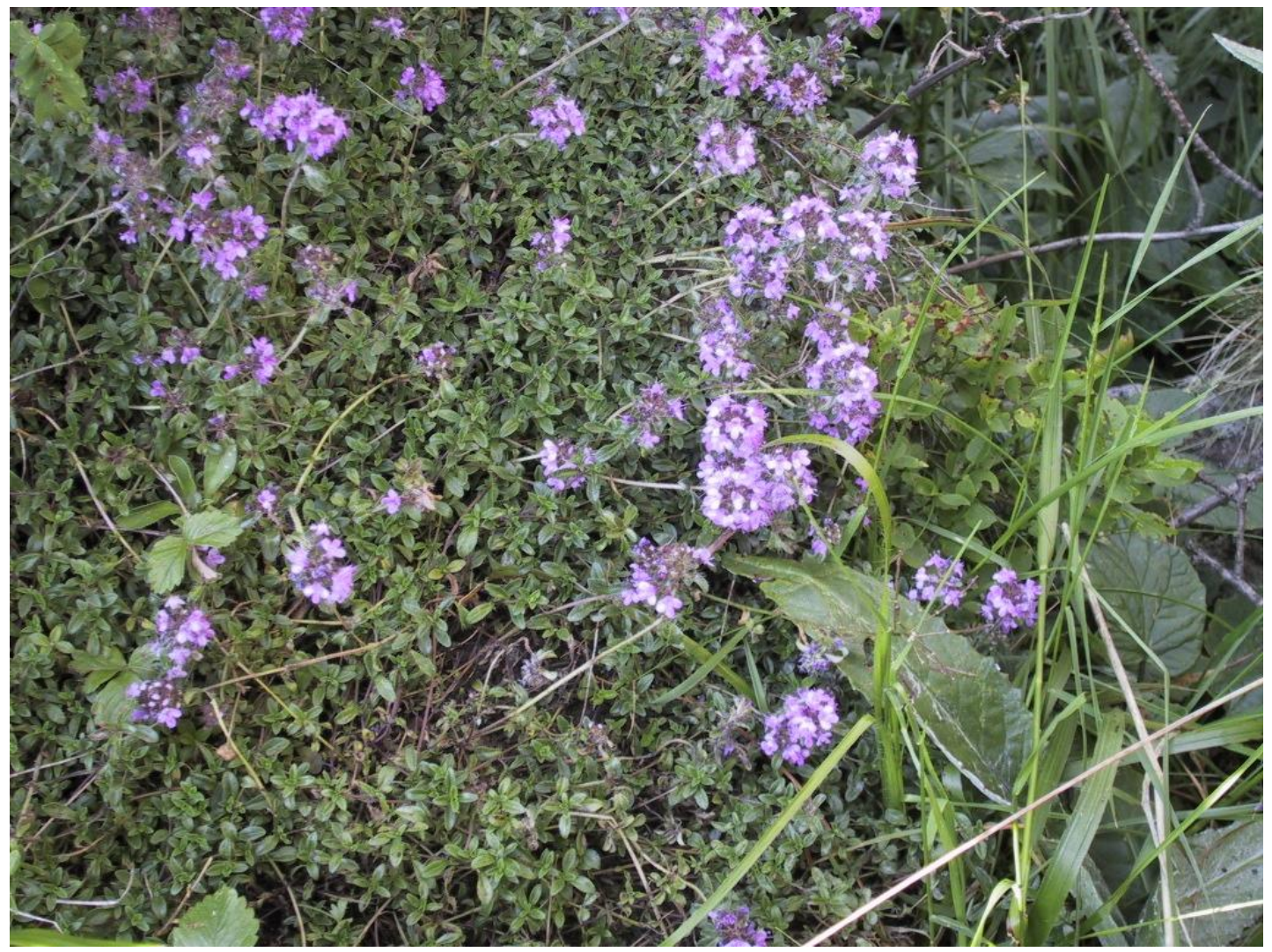

Slika 1.4. Thymus balcanus, populacija P25 (Foto I. Šoštarić).

Thymus glabrescens Willd (Slika 1.5) rasprostranjen je u centralnoj i istočnoj Evropi i u Srbiji je veoma česta vrsta, koja uspeva na zatravljenim, osunčanim površinama. Stabljika je prividno puzeća, leži na zemlji, a zatim se izdiže i završava fertilnim izdankom. Cvetne grane su ravnomerno pokrivene stršećim dlakama. Listovi na cvetnim granama izduženo lancetasti ili izduženo eliptični, na vrhu zaobljeni, sa lisno drškom izdvojenom i kratkom, na licu goli, a pri osnovi pokriveni dugačkim trepljama. Od vrha ka osnovi grana listovi se postepeno smanjuju. Cvetovi sakupljeni na vrhu 
grana i stabljike u klasolike cvasti. Vrsta je rasprostranjena u centralnoj i istočnoj Evropi.

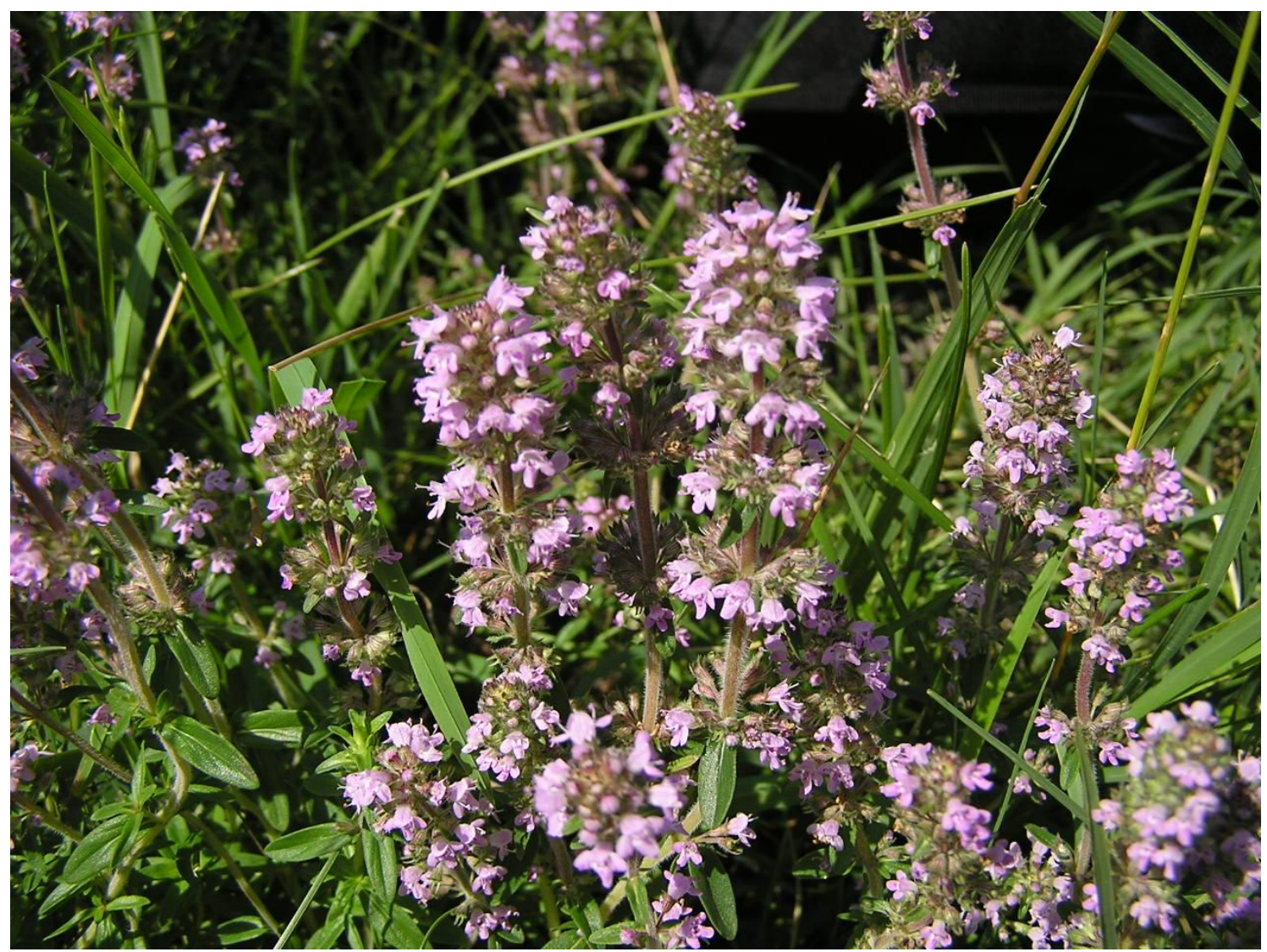

Slika 1.5. Thymus glabrescens, populacija P33 (Foto: D. Stojanović).

Thymus marschallianus Willd. (Slika 1.6) je rasprostranjen u celoj Evropi i na Balkanskom poluostrvu. U Srbiji ova vrsta ima veoma široko rasprostranjenje na livadama, sušnim brežuljcima i pored drumova. Glavno stablo je odrvenelo, uspravno ili se izdiže, završava se cvašću, najčešće sa brojnim fertilnim izdancima, koji su pokriveni stršećim dlakama. Listovi su linearno lancetasti do široko lancetasti ili eliptični, svi iste veličine ili su donji nešto sitniji, goli, samo pri osnovi sa dugačkim trepljama. Cvetovi skupljeni u klasolike cvasti. Prema Flori Srbije, vrsta je rasprostranjena u Evropi i na balkanskom poluostrvu. Flora Evrope ovu vrstu tretira kao deo vrste Th. pannonicus. 


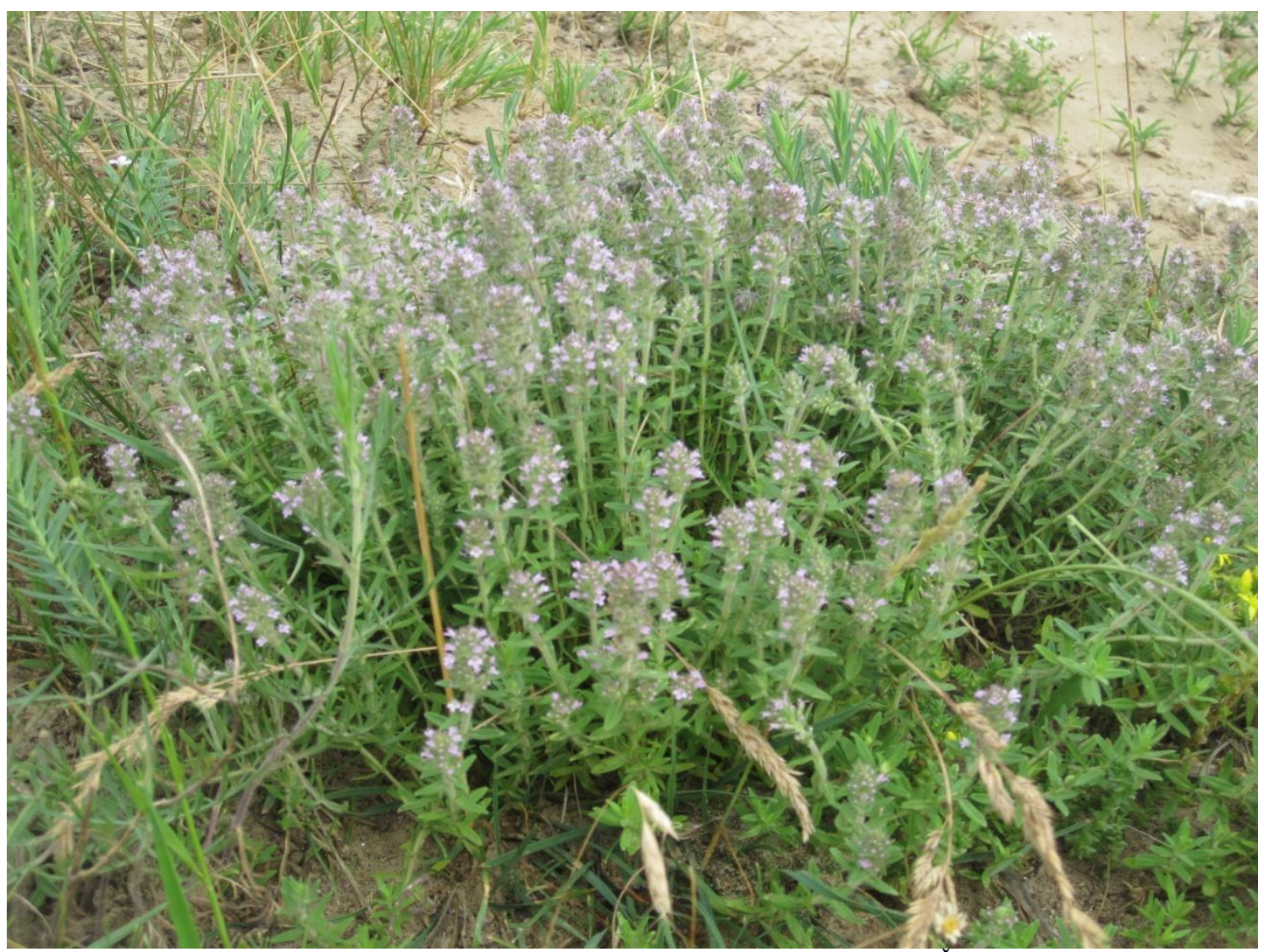

Slika 1.4. Thymus marschallianus, populacija P13 (Foto I. Šoštarić).

Thymus moesiacus Vel. (Slika 1.7) je vrsta sa stabljikom koja je puzeća, jako izdužena, vrhom neprestano raste i zavšava se sterilnom rozetom listova. Nežne cvetne grane se javljaju u nizovima duž položenog stabla iz pazuha listova, dugačke 5 do $8 \mathrm{~cm}$, pokrivene celom dužinom naniže okrenutim dlakama. Listovi koji se nalaze pri osnovi cvetnih grana, rozetasto su zbijeni, šilasti, mali, dugački svrga 5 do $6 \mathrm{~mm}$ i čiroki oko 1 mm, dok su listovi na sredini i u gornjem delu cvetnih grana veći, objajasti i dugački 11 do $20 \mathrm{~mm}$ i široki 2 do $5 \mathrm{~mm}$ sa utisnutim sitnim žlezdama. Listovi na stolonama su najčešće veći, ali ne i širi od listova na cvetnim granama. Svi listovi su na licu goli, a vrlo retko pokriveni dlakama. Cvetovi su složeni na vrhu cvetnih grana u kratke okruglaste, ređe nezbatno izdužene, cvasti. Čašica je dugačka oko $3 \mathrm{~mm}$ i sa svih strna pokrivena dugačkim, stršećim dlakama. Čašična cev je široko zvonasta, često kraća od čašičnih zubaca. Cvetne drške nisu pokrivene žlezdama sa drškama. Krunica spolja gola ili skoro gola. Ova vrsta je rasprostranjena na Balkanskom poluostrvu. U Flori Evrope navodi se da je Th. moesiacus sinonim za vrstu Th. longicaulis. 


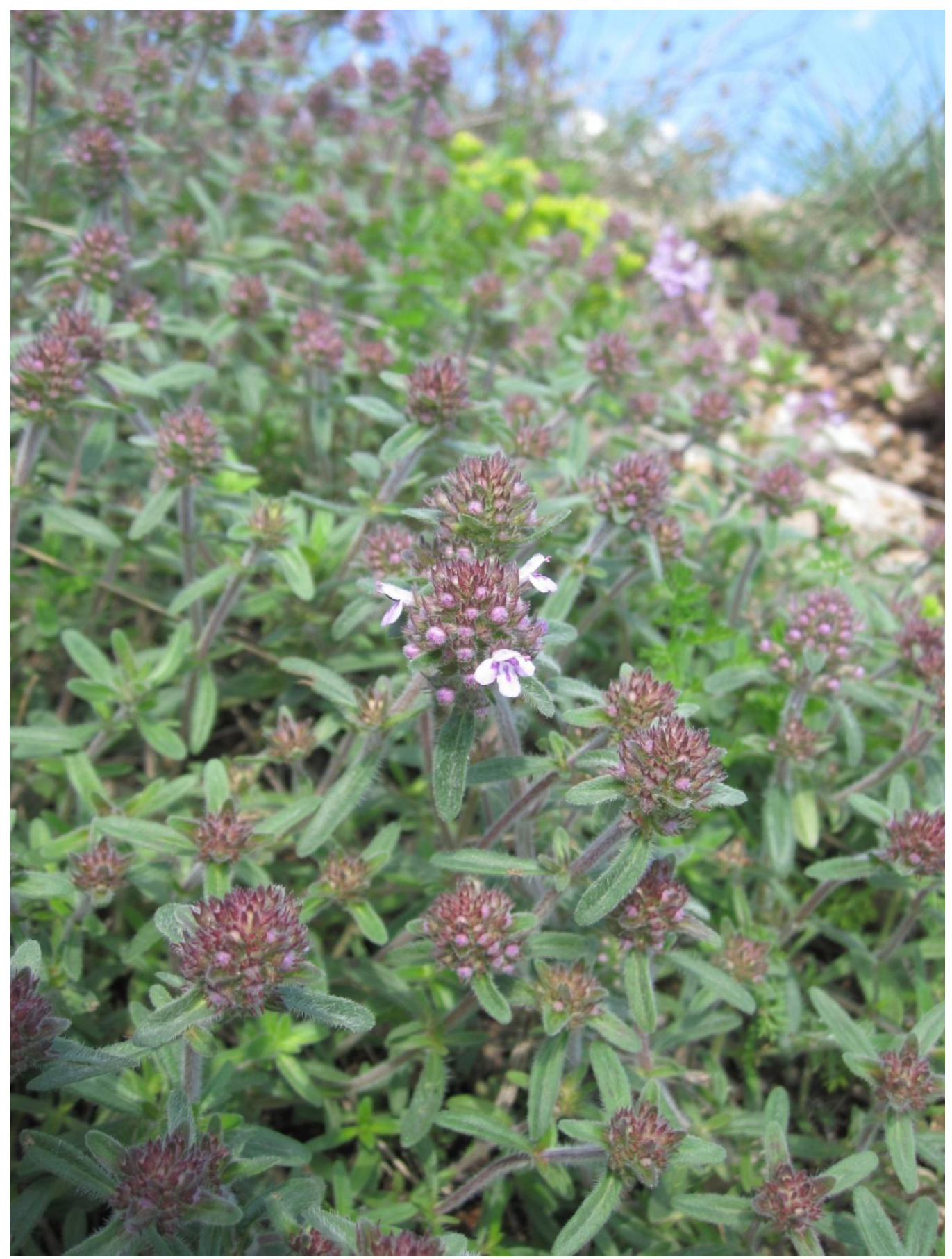

Slika 1.7. Th. moesiacus, populacija P30 (Foto: I. Šoštarić).

Thymus pannonicus All. (Slika 1.8) je biljka sa odrvenelom stabljikom koja donjim delom puzi po zemlji, dok se srednjim i donjim izdiže. Cvetne grane i sterilni izdanci su manje više uspravni. Ceo izdanak je gusto pokriven dlakama, cvetne grane i listovi su sa stršećim dugačkim dlakama. Listovi su linearno lancetasti ili izduženo lancetasti sa razvijenom lisno drškom. Na licu i na naličiju su utisnute subsesilne žlezde. 
Cvasti je klasoliko izdužena ili ređe okruglasta i skraćena. Cveta od maja do jula.Ova vrsta se javlja na osunčenim, zatravnjenim staništima. Rasprostranjena je u celoj Evropi, dok se u Srbiji javlja sporadično i to subvar. griseus.

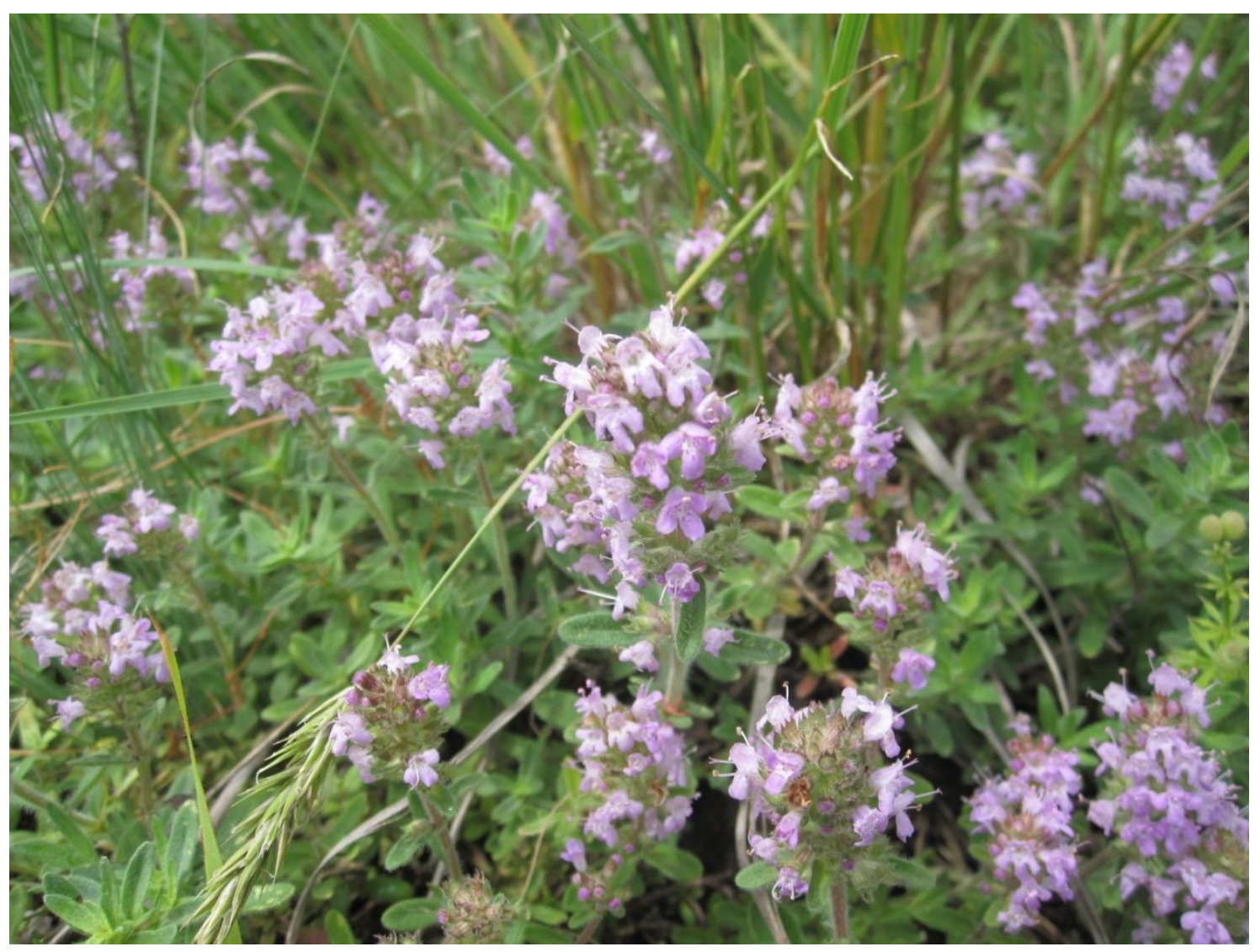

Slika 1.8. Th. pannonicus, populacija P23 (Foto: I. Šoštarić).

Thymus pulegioides L. (Slika 1.9) je busenasta biljka sa skoro uspravnim stabljikama, ili ove delimično delom leže na zemllji, dok krajevi sa cvastima stoje manje više uspravno. Stolone ili nisu razvijene ili su kratke. Cvetne grane su oštro četvorouglaste, uglovi malo istaknuti, sve do cvasti pokriveni naniže okrenutim dlakama. Stranice su gole. Listovi jajasti, eliptično jajasti, izduženi ili lancetasti. Cvetovi sakupljeni na vrhu cvetnih grana u vršne, izdužene klasolike ili okruglaste cvasti. Čašična cev i zupci na gornjoj usni goli ili pokriveni dlakama, zupci donje čašične usne uvek duž oboda pokriveni trepljama. Ova vrsta ima veoma široko rasprostranjenje. Javlja se u severnoj, centralnoj i jugoistočnoj Evropi. 


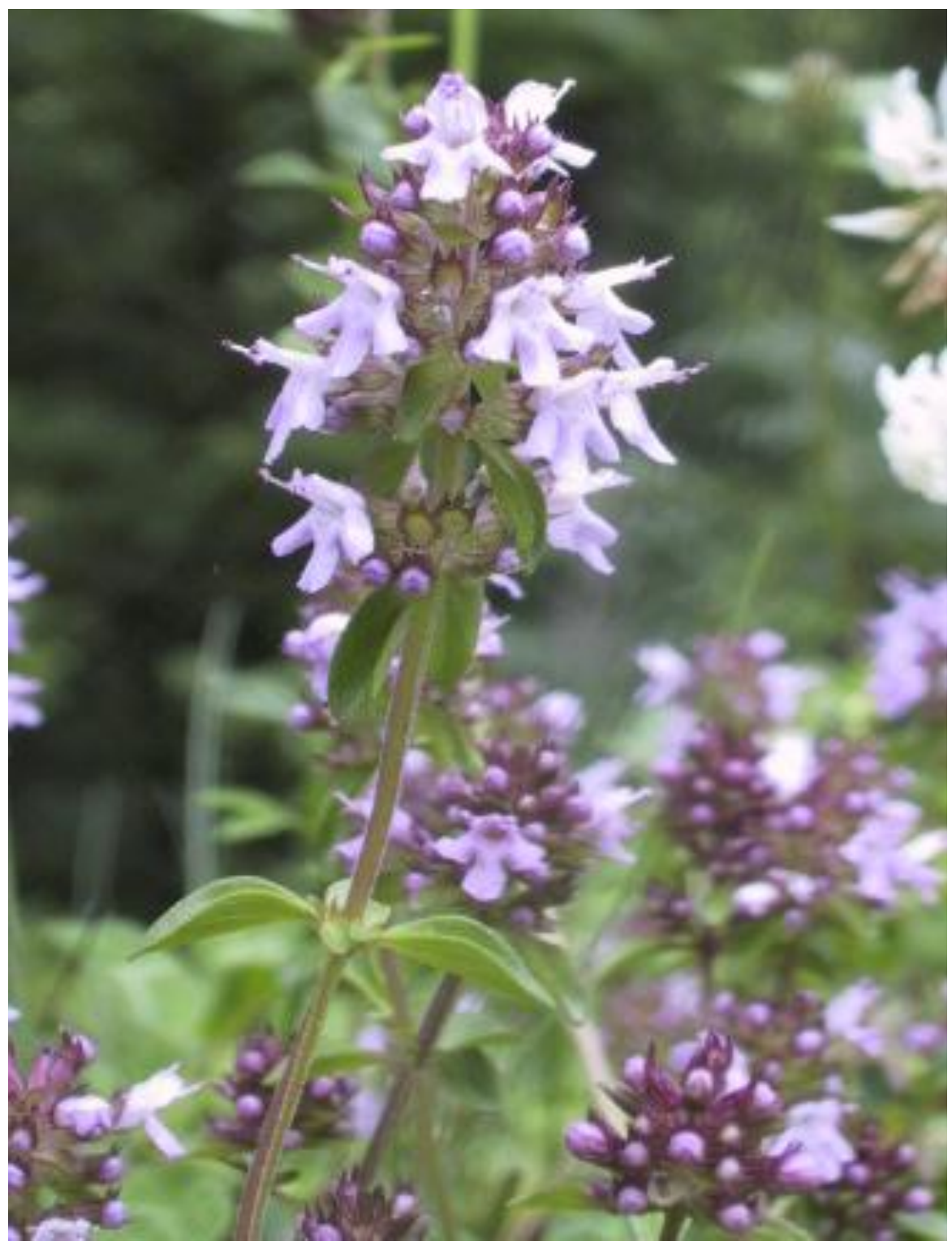

Slika 1.9. Th. pulegioides, populacija P05 (Foto: I. Šoštarić).

Thymus praecox Opiz. je sa stabljikama koje su dugačke, puze po zemljii završavaju se sterilnom rozetom listova. Cvetne grane se razvijaju u nizovima, duž položenog stabla i visoke su 3 do $5 \mathrm{~cm}$, pokrivene stršećim dlakama koje su kraće od prečnika stabljike. Donji listovi cvetnih grana loptičasto okruglasti sa dugačkom lisno drškom, nisu zbijeni u rozete, srednji listovi su jajasti, a gornji jajasto okruglasti, postepeno sve veći, svi sa dobro razvijenom lisno drškom, kožasti na licu goli, bočni nervi na naličiju liske istaknuti, debeli, me ulivaju se u isto tako debeli obodni nerv. Cvetovi su složeni na vrhu cvetnih grana u okruglaste cvasti. Čašica je dugačka oko 4 mm i sa trbušne strane je pokrivena dlakama. Prema Flori Srbije ova vrsta je endemit 
Balkanskog poluostrva, dok Flora Evrope navodi da je areal ove vrste znatno širi, od južnih obala Grenlanda, pa sve do jugoistočne Evrope.

\subsection{Ciljevi rada}

Vrste roda Thymus koriste se kao lekovite i aromatične biljke u tradicionalnoij i zvaničnoj medicini u svim krajevima u kojima se javljaju. Aktivne supstance uglavnom su u sastavu etarskih ulja te je poznavanje različitih hemotipova od velikog značaja pri odabiru populacija za kolekcionisanje biljnog materijala.

Pri determinaciji vrsta roda Thymus morfološki karakteri često su nedovoljno jasni, tako da se ukazuje potreba za dodatnim karakterima za određivaje vrsta. Shodno tome, analiza površinskih flavonoida i AFLP molekularnih markera poboljšaćeuvid $\mathrm{u}$ genetičke i evolutivne odnose između populacija vrsta ovog roda sa područja Srbije. Na kraju, na osnovu dobijenih rezultata fitohemijskih i molekularnih istraživanja i utvrđenih srodničkih odnosa između istraživanih vrsta kao model sistema unutar roda Thymus, očekuje se i rasvetljavanje određenih taksonomskih pitanja. Dobijeni rezultati treba da ukažu na smernice za dalja taksonomska i filogenetska istraživanja ne samo vrsta iz drugih sekcija roda Thymus, nego i srodnih rodova iz tribusa Mentheae, jedne od najznačajnijih, najkompleksnijih i najintrigantnijih grupa familije Lamiaceae. 


\section{Metrijal i metode}

\subsection{Fitohemijska ispitivanja}

\subsubsection{Biljni materijal}

Biljni materijal za fitohemijska ispitivanja sakupljan je tokom vegetacione sezone 2008. godine sa svojih prirodnih staništa. Spisak vrsta sa lokalitetom i njegovom geografskom dužinom i širinom dat je u tabeli 2.1. Uzorci su determinisani u skladu sa Flora Europaea i Florom SR Srbije. Herbarski uzorci se čuvaju u Herbarijumu Katedre za agrobotaniku Poljoprivrednog fakulteta, Univerziteta u Beogradu.

\subsubsection{Etarska ulja}

\subsubsection{Analiza sastava etrskih ulja}

TD-GC-MS sistem se sastojao od an ATD400 termo-desorpcoine jedinice, AutoSystem XLGC i TurboMass quadrupole MS (Perkin-Elmer, Waltham, MA). Oko $3 \mathrm{mg}$ vazdušno sušenog biljnog materijala je držano izmežu staklene vune u staklenoj cevi i stavljeno u standardnu desorpcionu cev od nerđajućeg čelika. Uzorak je potom desorbovan 10 minuta na $150^{\circ} \mathrm{C}$ u toku helijuma od $60 \mathrm{~mL} / \mathrm{min}$ koji je prolazio do Tenax TA trap (80-100 mesh) držanog na $4{ }^{\circ} \mathrm{C}$ bez rascepa ulaza. Nakon desorpcije Tenax trap je grejana na $300{ }^{\circ} \mathrm{C}$ u helijumovoj atmosferi na 15 psi sa ispustnim rascepljenim protokom od $18.75 \mathrm{~mL} / \mathrm{min}$. Isparljive komponente su propuštane $\mathrm{kroz}$ deaktivacionu staklenu kapilarnu liniju na $200{ }^{\circ} \mathrm{C}$ na $30 \mathrm{~m}$ x $0.25 \mathrm{~mm}$ i.d. x $0.25 \mu \mathrm{m}$ DB-5MS kapilarnu GC kolonu (Agilent J\&W, Santa Clara, CA) i hromatografija je bila nastavljena upotrebom temperaturnog programa od $60-300$ na $6{ }^{\circ} \mathrm{C} / \mathrm{min}$ pod pritiskom ATD. MS je bio opremljen EI izvorom koji je radio na $70 \mathrm{eV}$ sa temperaturom izvora od of $180{ }^{\circ} \mathrm{C}$, dok su maseni spektri bili zabeleženi u opsegu m/z 38-600. Operativni 
softver je bio Turbomass version 4.1.1. Retencioni indeksi (RI) su bili određeni $u$ relaciji sa serijom n-alkana (C8-C20, Supelco, United Kingdom), dok je integracija pikova bila izvedena do RI 1900 (t.j. pre izlaska palmitinske kiseline). Jedinjenja su određen upoređivanjem RI i/ili masenog spektra sa literaturnim podatcima (Adams, 2001; Ausloos i sar., 1992).

\subsubsection{Statistička obrada sastava etarskih ulja}

U statističku obradu sastava etarskih ulja za svaku podsekciju uključene su komponente koje se u makar jednom uzorku javljaju sa 10 ili više procenata. Kod podsekcije Alternantes $\mathrm{u}$ analizu je uključeno 5 komponenti etarskih ulja, kod popdsekcije Isolepides 15 komponenti i kod podsekcije Pseudomarginati 10 komponenti (Tabela 2.2).

Korelacije: $\mathrm{Na}$ osnovu Pearsonovog korelacijskog koeficijenta izračunate su korelacije između najzasupljenijih komponenti etarskog ulja unutar svake podsekcije upotrebom programa programa Statistica 8.0 (StatSoft).

Analiza glavnih komponenti: PCA(Principal Component Analysis) je multivarijacion statisticka metoda koja veliki broj korelisanih promenljivih transformise $\mathrm{u}$ nekorelisanih skup promenjljivih koje se nazivaju glavne pomponente. Analiza glavnih komponenti je sprovedena na osnovu najzastupljenijih komponenti etarskog ulja unutar svake podsekcije pomoću programa Statistica 8.0 (StatSoft). Izrađeni su dijagrami, za svaku podsekciju, u kojima je u koordinatnom sistemu tačkama prikazan položaj analiziranih populacijama, kao i dijagrami u kojima je tačkama prikazan položaj pojedinih komponenti etarskog ulja.

Klaster Analiza: $\mathrm{Na}$ osnovu najzastupljenijih komponenti etarskog ulja izračunata je Euklidska udaljenost između populacija unutar svake podsekcije. Matrica Euklidske udaljenosti korištena je u Analizi skupina (Cluster Analysis) u svrhu izrade dendrograma odnosno utvrdjivanja stepena slicnsti medju populacijama. Klaster analiza je izvršena neponderisanom metodom za sparivanje skupina na temelju prosečnih vrednosti (Unweighted pair-group method using arithmetic averages; UPGMA). Klaster analiza je izvršena na standarzizovanim podacima. 
Tabela 2.1. Populacije vrsta roda Thymus uključene u fitohemijska ispitivanja.

\begin{tabular}{|c|c|c|c|c|c|}
\hline ThAFLP_No & Vrsta & Podsekcija & $\begin{array}{c}\text { Geografska } \\
\text { širina }(\mathrm{N})\end{array}$ & $\begin{array}{c}\text { Geografska } \\
\text { dužina (E) }\end{array}$ & $\begin{array}{c}\text { Nadmorska } \\
\text { visina }(\mathrm{m})\end{array}$ \\
\hline P01 & Th. pulegioides & Alternantes & 43.84 & 21.68 & 592 \\
\hline $\mathrm{P} 02$ & Th. pulegioides & Alternantes & 43.88 & 20.66 & 473 \\
\hline P03 & Th. pulegioides & Alternantes & 43.45 & 21.47 & 648 \\
\hline P04 & Th. pulegioides & Alternantes & 43.61 & 20.55 & 264 \\
\hline P05 & Th. pulegioides & Alternantes & 43.38 & 22.60 & 1163 \\
\hline P06 & Th. pulegioides & Alternantes & 44.17 & 21.12 & 877 \\
\hline P09 & Th. pulegioides & Alternantes & 45.16 & 19.75 & 474 \\
\hline $\mathrm{P} 10$ & Th. glabrescens & Isolepides & 44.82 & 21.34 & 80 \\
\hline $\mathrm{P} 11$ & Th. glabrescens & Isolepides & 45.07 & 21.38 & 132 \\
\hline $\mathrm{P} 12$ & Th. glabrescens & Isolepides & 45.29 & 20.43 & 84 \\
\hline $\mathrm{P} 13$ & Th. glabrescens & Isolepides & 45.10 & 21.39 & 155 \\
\hline P14 & Th. glabrescens & Isolepides & 45.48 & 20.34 & 79 \\
\hline P15 & Th. glabrescens & Isolepides & 45.16 & 19.75 & 474 \\
\hline P33 & Th. glabrescens & Isolepides & 45.28 & 20.38 & 83 \\
\hline P16 & Th. marschallianus & Isolepides & 45.00 & 20.89 & 145 \\
\hline $\mathrm{P} 17$ & Th. marschallianus & Isolepides & 44.90 & 21.22 & 114 \\
\hline $\mathrm{P} 18$ & Th. marschallianus & Isolepides & 43.60 & 21.88 & 793 \\
\hline P19 & Th. pannonicus & Isolepides & 43.59 & 21.89 & 926 \\
\hline $\mathrm{P} 20$ & Th. pannonicus & Isolepides & 43.73 & 21.85 & 802 \\
\hline $\mathrm{P} 21$ & Th. pannonicus & Isolepides & 44.17 & 21.12 & 877 \\
\hline $\mathrm{P} 22$ & Th. pannonicus & Isolepides & 44.18 & 22.13 & 975 \\
\hline $\mathrm{P} 23$ & Th. pannonicus & Isolepides & 45.12 & 21.32 & 402 \\
\hline P34 & Th. pannonicus & Isolepides & 44.19 & 22.16 & 869 \\
\hline $\mathrm{P} 24$ & Th. balcanus & Pseudomarginati & 43.36 & 22.58 & 1491 \\
\hline $\mathrm{P} 25$ & Th. balcanus & Pseudomarginati & 43.37 & 22.62 & 1758 \\
\hline P26 & Th. balcanus & Pseudomarginati & 43.27 & 22.81 & 1551 \\
\hline $\mathrm{P} 27$ & Th. balcanus & Pseudomarginati & 43.25 & 22.81 & 1454 \\
\hline
\end{tabular}




\begin{tabular}{cccccc}
\hline ThAFLP_No & Vrsta & Podsekcija & $\begin{array}{c}\text { Geografska } \\
\text { širina }(\mathrm{N})\end{array}$ & $\begin{array}{c}\text { Geografska } \\
\text { dužina (E) }\end{array}$ & $\begin{array}{c}\text { Nadmorska } \\
\text { visina }(\mathrm{m})\end{array}$ \\
\hline P31 & Th. moesiacus & Pseudomarginati & 43.61 & 20.55 & 275 \\
P32 & Th. praecox & Pseudomarginati & 44.18 & 22.14 & 1162 \\
\hline
\end{tabular}

Tabela 2.1 Nastavak

Tabela 2.2. Sastojci etarskog ulja uključena u statističku obradu.

\begin{tabular}{|c|c|c|c|}
\hline Jedinjenje & KI Literaturno & Tip jedinjenja & Podsekcija kod koje je uključena \\
\hline$\alpha$-Pinene & 939 & Monoterpenski ugljovodonici & $\mathrm{I}$ \\
\hline Myrcene & 991 & Monoterpenski ugljovodonici & $\mathrm{I} ; \mathrm{P}$ \\
\hline p-Cymene & 1025 & Ostalo (aromatični ugljovodonik) & $\mathrm{A} ; \mathrm{I}$ \\
\hline Limonene & 1029 & Monoterpenski ugljovodonici & $\mathrm{I}$ \\
\hline (E)- $\beta$-Ocimene & 1050 & Monoterpenski ugljovodonici & $\mathrm{I}$ \\
\hline$\gamma$-Terpinene & 1060 & Monoterpenski ugljovodonici & $\mathrm{A} ; \mathrm{I}$ \\
\hline Linalool & 1097 & Oksigenovani monoterpenski ugljovodonici & $\mathrm{I} ; \mathrm{P}$ \\
\hline$\alpha$-Terpineol & 1189 & Oksigenovani monoterpenski ugljovodonici & $\mathrm{I}$ \\
\hline Thymol methyl ether & 1235 & Ostalo (fenolni etar) & $\mathrm{I}$ \\
\hline Neral & 1238 & Oksigenovani monoterpenski ugljovodonici & $\mathrm{I} ; \mathrm{P}$ \\
\hline Geraniol & 1253 & Oksigenovani monoterpenski ugljovodonici & $\mathrm{A}$ \\
\hline Linalyl acetate & 1257 & Oksigenovani monoterpenski ugljovodonici & $\mathrm{P}$ \\
\hline Geranial & 1267 & Oksigenovani monoterpenski ugljovodonici & $\mathrm{I} ; \mathrm{P}$ \\
\hline Thymol & 1290 & Ostalo (fenol) & A: I; \\
\hline Carvacrol & 1299 & Ostalo (fenol) & $\mathrm{A} ; \mathrm{I}$ \\
\hline alpha-Terpinyl acetate & 1349 & Oksigenovani monoterpenski ugljovodonici & $\mathrm{P}$ \\
\hline Neryl acetate & 1362 & Oksigenovani monoterpenski ugljovodonici & $\mathrm{P}$ \\
\hline (E)-Caryophyllene & 1419 & Seskviterpenski ugljovodonik & $\mathrm{I} ; \mathrm{P}$ \\
\hline Germacrene-D & 1485 & Seskviterpenski ugljovodonik & $\mathrm{I}$ \\
\hline Bicyclogermacrene & 1500 & Seskviterpenski ugljovodonik & $\mathrm{P}$ \\
\hline (E)-gamma-Bisabolene & 1531 & Seskviterpenski ugljovodonik & $\mathrm{I} ; \mathrm{P}$ \\
\hline
\end{tabular}

* A - Alternantes; I - Isolepides; P- Pseudomarginati; 


\subsubsection{Površinski flavonoidi}

\subsubsection{Ekstrakcija površinskih flavonoida}

Za analizu je korišćeno $0.5 \mathrm{~g}$ vazdušno sušenih, celih listova su bili potopljeni u $10 \mathrm{ml}$ dietil etra i ostavljeni na sobnoj temperaturi preko noći. Dietil etar je filtriran i ostavljen da ispari u digestoru. Suvi ostatak je zatim rastvoren u $80 \% \mathrm{MeOH}$, filtriran i prebačen $u$ autosampler HPLC vijalu.

\subsubsection{Analitički HPLC sa diodnom UV detekcijom (LC-DAD)}

HPLC sistem se sastojao od Waters LC 600 pumpe i 996 fotodiodnim UV detektorom. Korištene su kolone Merck LiChrospher 100RP-18 (5 $\mu \mathrm{m}), 4.0$ mm (i.d.)x $250 \mathrm{~mm}$.Gradijentni profili su bili zasnovani na dva rastvarača, $2 \%$ vodenim HOAc i $\mathrm{MeOH}-\mathrm{HOAc}-\mathrm{H} 2 \mathrm{O}$, 18:1:1. Početni uslovi su bili $75 \%$ vodenog rastvarača i $25 \%$ metanolnog rastvarača. Proporcija ovog drugog rastvarača je rasla sa linearnim gradijentom, dostižući $100 \%$ sa $t=20 \mathrm{~min}$. Posle ovoga je sledila izokratska elucija $100 \%$ metanolnog rastvarača do $t=25 \mathrm{~min}$, nakon čega se program vraćao na početni odnos

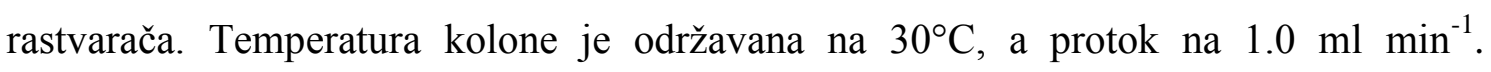
Injekcije $(40 \mu 1)$ su vršene autosamplerom.

\subsubsection{HPLC sa hemijski jonizujućom masenom spektrometrijom na atmosferskom pritisku (LC-APCI-MS)}

LC-MS analiza je izvedena na sličan način kao i analitička HPLC metoda, s tim što je koncentracija sirćetne kisleine u mobilnim fazama bila $1 \%$. Maseni spektri su snimljeni kvadrupol - jonska zamka masenim spektrometrom (ThermoFinnigan LCQ 'classic') sa hemijskim jonizacionim izvorom pri atmosferskom pritisku (APCI) u pozitivnom modu. Temperatura grejača jonske probe je bila $550{ }^{\circ} \mathrm{C}$, pritisci gasa pri direktnom i kružnom protoku kroz jonsku probu iznosili su 80 i 20 psi, respektivno, temperatura kapilare $150{ }^{\circ} \mathrm{C}$, a jačina jonizacione struje je bila $5 \mu \mathrm{A}$. Masenim 
spektrometrom je upravljano preko programa Xcalibur 1.2 (ThermoFinnigan). Spektri su snimani u opsegu 125 - $500 \mathrm{~m} / \mathrm{z}$. Najobilniji joni u svakom spektru su izdvojeni u jonskoj zamci (širina izolovanja od $5 \mathrm{amu}$ ) i zatim podvrgnuti kolizionoj disocijaciji (CID) primenom kolizione energije od $45 \%$ (bez energije aktivacije). CID spektri koeluirajućih komponenti su zabeleženi automatski dinamičkim isključivanjem bez prethodnog poznavanja njihovih molekulskih masa.

\subsection{Molekularna ispitivanja}

\subsubsection{Biljni materijal}

Biljni materijal za molekularna ispitivanja sakupljan je tokom vegetacione sezone 2008. godine sa svojih prirodnih staništa. Spisak vrsta sa lokalitetom i njegovom geografskom dužinom i širinom dat je u tabeli 2.3. Uzorci su determinisani u skladu sa Flora Europaea i Florom SR Srbije. Herbarski uzorci se čuvaju u Herbarijumu Katedre za agrobotaniku Poljoprivrednog fakulteta, Univerziteta u Beogradu. 
Tabela 2.3. Vrste i populacije roda Thymus uklučene u AFLP analizu.

\begin{tabular}{|c|c|c|c|c|c|}
\hline Poulacija & Vrsta & Podsekcia & $\begin{array}{l}\text { Geografska } \\
\text { širina }(\mathrm{N})^{\#}\end{array}$ & $\begin{array}{l}\text { Geografska dužina } \\
\text { (E) }\end{array}$ & $\begin{array}{c}\text { Broj } \\
\text { uzoraka. }\end{array}$ \\
\hline P01 & Th. pulegioides & Alternantes & 43.84 & 21.68 & 3 \\
\hline $\mathrm{P} 02$ & Th. pulegioides & Alternantes & 43.88 & 20.66 & 3 \\
\hline $\mathrm{P} 03$ & Th. pulegioides & Alternantes & 43.45 & 21.47 & 3 \\
\hline P04 & Th. pulegioides & Alternantes & 43.61 & 20.55 & 3 \\
\hline P05 & Th. pulegioides & Alternantes & 43.38 & 22.60 & 2 \\
\hline P06 & Th. pulegioides & Alternantes & 44.17 & 21.12 & 3 \\
\hline P07 & Th. pulegioides & Alternantes & 43.19 & 22.14 & 3 \\
\hline P08 & Th. pulegioides & Alternantes & 44.26 & 19.89 & 3 \\
\hline P09 & Th. pulegioides & Alternantes & 45.16 & 19.75 & 2 \\
\hline $\mathrm{P} 10$ & Th. glabrescens & Isolepides & 44.82 & 21.34 & 2 \\
\hline P11 & Th. glabrescens & Isolepides & 45.07 & 21.38 & 3 \\
\hline $\mathrm{P} 12$ & Th. glabrescens & Isolepides & 45.29 & 20.43 & 3 \\
\hline $\mathrm{P} 13$ & Th. glabrescens & Isolepides & 45.10 & 21.39 & 3 \\
\hline $\mathrm{P} 14$ & Th. glabrescens & Isolepides & 45.48 & 20.34 & 2 \\
\hline P15 & Th. glabrescens & Isolepides & 45.16 & 19.75 & 3 \\
\hline $\mathrm{P} 16$ & Th. marschallianus & Isolepides & 45.00 & 20.89 & 3 \\
\hline P17 & Th. marschallianus & Isolepides & 44.90 & 21.22 & 2 \\
\hline P18 & Th. marschallianus & Isolepides & 43.60 & 21.88 & 3 \\
\hline P19 & Th. pannonicus & Isolepides & 43.59 & 21.89 & 2 \\
\hline $\mathrm{P} 20$ & Th. pannonicus & Isolepides & 43.73 & 21.85 & 3 \\
\hline $\mathrm{P} 21$ & Th. pannonicus & Isolepides & 44.17 & 21.12 & 1 \\
\hline $\mathrm{P} 22$ & Th. pannonicus & Isolepides & 44.18 & 22.13 & 2 \\
\hline $\mathrm{P} 23$ & Th. pannonicus & Isolepides & 45.12 & 21.32 & 3 \\
\hline $\mathrm{P} 24$ & Th. balcanus & Pseudomarginati & 43.36 & 22.58 & 1 \\
\hline $\mathrm{P} 25$ & Th. balcanus & Pseudomarginati & 43.37 & 22.62 & 2 \\
\hline $\mathrm{P} 26$ & Th. balcanus & Pseudomarginati & 43.27 & 22.81 & 3 \\
\hline $\mathrm{P} 27$ & Th. balcanus & Pseudomarginati & 43.25 & 22.81 & 3 \\
\hline $\mathrm{P} 28$ & Th. balcanus & Pseudomarginati & 44.17 & 21.12 & 3 \\
\hline $\mathrm{P} 29$ & Th. balcanus & Pseudomarginati & 44.17 & 21.12 & 2 \\
\hline $\mathrm{P} 30$ & Th. moesiacus & Pseudomarginati & 43.88 & 20.66 & 3 \\
\hline P31 & Th. moesiacus & Pseudomarginati & 43.61 & 20.55 & 3 \\
\hline $\mathrm{P} 32$ & Th. praecox & Pseudomarginati & 44.18 & 22.14 & 3 \\
\hline
\end{tabular}

\subsubsection{Ekstrakcija DNA i AFLP analiza}

Totalna genomska DNA je ekstrkovana iz 20mg suvih listova sušenih u silika gelu upotrebom DNeasy Plant Mini Kit $\left(\right.$ Qiagen $\left.^{\circledR}\right)$. Koncentracija DNA je merena upotrebom Qubit Fluorometer (Invitrogen ${ }^{\circledR}$ ). AFLP je izveden u skladu sa protokolom kako su ga opisali Vos et al. (1995), ali uz nekoliko modifikacija. Restrikciona digestija i ligacija adaptera su vršene simultano na 200ng genomske DNA u totalnoj zapremini 
$33 \mu \mathrm{l}$ u trajanju od 2 sata na $37^{\circ} \mathrm{C}$, a potom 14 sati na $23^{\circ} \mathrm{C}$. Restrikciona digestija $\mathrm{i}$ ligacija adaptera, preamplifikacija i selektivna amplifikacija su izvođene na GeneAmp ${ }^{\circledR}$ PCR System 9700 (Applied Biosystems ${ }^{\circledR}$ ). Za amplifikaciju je izabrano osam kombinacija prajmera, i to:

- FAM-EcoRIACA+Tru1ICAG,

- NED-EcoRIAGC+Tru1ICGG,

- VIC-EcoRIACGC+Tru1ICAG,

- PET-EcoRIATG+Tru1ICGG,

- FAM-EcoRIACT+Tru1ICAG,

- NED-EcoRIAGC+Tru1ICAG,

- VIC-EcoRIACG+Tru1ICGA i

- PET-EcoRIACC+Tru1ICGA.

Pripremljeni uzorci su detektovani pomoću ABI3130xl Genetic Analyzer (Applied Biosystems ${ }^{\circledR}$ ). Prisustvo ili odsustvo fragmenata je zabeleženo sa GeneMapper 4.0 software (Applied Biosystems ${ }^{\circledR}$ ). Svi fragmenti između 50 i 500 bp su zabeleženi. Dobijeni pikovi su automatski prebačeni u binarni matriks. Ukolio je pik prelazio apsolutnu vrednost od 50, prema automatskom podešavanju donje granice amplitude GeneMapper 4.0, pik je bio registrovan kao prisutan (1), a u suprotnom kao odsutan (0).

\subsubsection{Analiza podataka}

Šenonov inforamacioni indeks kao mera diverziteta AFLP unutar vrste je računat kao $H_{j}=-\Sigma\left(p_{i} \log _{2} p_{i}\right)$, gde je $p_{i}$ fenotipska frekvencija (Lewontin, 1972). Šenonov indeks je korišćen i za izražavanje totalnog diverziteta $\left(\mathrm{H}_{\mathrm{t}}\right)$ kao i za prosečni intraspecijski diverzitet $\left(\mathrm{H}_{\mathrm{sp}}\right)$ i proporciju diverziteta unutar $\left(\mathrm{H}_{\mathrm{sp}} / \mathrm{H}_{\mathrm{t}}\right)$ i među vrstama $\left[\left(\mathrm{H}_{\mathrm{t}}-\mathrm{H}_{\mathrm{sp}}\right) / \mathrm{H}_{\mathrm{t}}\right]$.

Analiza molekularne varijanse (AMOVA; Excoffier et al., 1992) je sprovedena na Nei i Lievoj matrici udaljenosti među jedinkama upotrebom Arlequin ver. 2.000 (Schneider et al., 2000). 
Dvosmerna AMOVA je korišćena da bi se totalna varijansa raščlanila među vrstama, među populacijama unutar vrsta i unutar populacionih komponenti. Dodatne jednosmerne AMOVA-e su sprovedene da bi se totalna varijabilnost raščlanila na, među i unutar populacionu komponentu svake vrste Thynus (osim Th. praecox kod kojega je ispitivana samo jedna populacija).

Komponentne varijanse su testirane statistički neparametarskim nasumičnim testom uz upotrebu 10.000 permutacija. Međusobno poređenje vrsta pomoću AMOVA-e rezultovalo je sa $\phi_{S T}$ vrednostima koje su ekvivalentne totalnoj varijansi koja je podeljena između dve vrste i može biti interpretirana kao prosečna međuspecijska udaljenost između bilo koje dve vrste (Huff, 1997).

Klaster analiza zasnovana na Nei i Lijevoj matrici rastojanja između individual je izvedena upotrebom Neighbour Joining metoda (Saitou i Nei, 1987)primenom TREECON for Windows ver. 1.3 b (Van de Peer i De Wachter, 1994). Bootstrap analiza je izvršena na 1000 bootstrap uzoraka (Felsenstein, 1985).

Modelno zasnovan klasterski metod je primenjen na multilocus AFLP podatke da bi se dobila genetska struktura i odredio broj klastera u skupu podataka upotrebom softvera STRUCTURE (Pritchard et al., 2000). Za datu vrednost broja klastera, ovaj metod pridružuje pojedinačne genotipove iz ukupnog uzorka klasterima na takav način da neuravnoteženost povezivanja (LD) bude najbolje objašnjena. Za svaku vrednost K izvršeno je 10 prolaza uzimajući broj klastera (K) od 1 do 10 . Svaki prolaz se sastojao od burn-in perioda od 20.000 koraka, posle čega je izvršeno $10^{5}$ MCMC (Monte Carlo Markov Chain) replikacija uz pretpostavku admixture modela i korelacije alelskih frekvencija. Nisu korišćene nikakve prethodne informacije za definisanje klastera. Izbor najverovatnijeg broja klastera $(\mathrm{K})$ izvršen je upoređivanjem prosečnih procena sličnosti podataka $\ln [\operatorname{Pr}(X \mid K)]$, za svaku vrednost K (Pritchard et al. 2000), kao i izračunavanjem ad hoc statistike $\Delta \mathrm{K}$, zasnovane na stopi promene logaritma verovatnoće podataka za uzastopne vrednosti K, kako je opisano u Evanno et al. (2005). 


\section{Rezultati}

\subsection{Fitohemijska ispitivanja}

\subsubsection{Etarska ulja}

U etarskim uljima ispitivanih populacija roda Thymus sa područja Srbije utvrđeno je prisustvo ukupno 103 jedinjenja, dok se učešce determinisanih jedinjenja kretalo od $88.98 \%$ kod Th. praecox (P32) do 99.47\% kod Th. glabrescens (P13).

Najbrojnija grupa jedinjenja, sa ukupno 39 detrerminisanih komponenti, su seskviterpenski ugljovodonici. Nakon njih po brojnosti dolaze oksigenovani monoterpenski ugljovodonici, sa ukupno 30 jedinjenja, i monoterpenski ugljovodonici sa 17 jedinjenja. Osim toga, u sastav etarskih ulja ispitivanih vrsta roda Thymus, ulaze i 4 aromatična ugljovodonika, 3 oksigenovana seskviterpenaska ugljovodonika, 3 fenolna jedinjenja, 3 nezasićena alkohola, 2 fenolna etra i po 1 nezasićeni alkohol i keton.

\subsubsection{Sastav etraskih ulja Thymus pulegioides}

Kod sedam ispitivanih populacija vrste Th. pulegioides utvrđeno je prisustvo 73 komponente $\mathrm{u}$ etarskim uljima, $\mathrm{i}$ to 16 monoterpenskih ugljovodonika, 18 oksigenovanih ugljovodonika, 26 seskviterpenskih ugljovodonika i 12 jedinjenja koja ne pripadaju ni jednoj od tri glavne grupe (Tabela 3.1). Kod populacije P02 determinisana je ukupno 41 komponenta, kod populacije P05 i populacije P01 39 komponenti, kod populacije P06 38 komponenti, kod populacije P03 32 komponente, kod populacije P04 30 i kod populacije P09 26 komponenti.

Monoterpenski ugljovodonici: $\mathrm{U}$ etarskim uljima ispitivanih populacija $T h$. pulegioides identifikovano je prisustvo 16 monoterpenskih ugljovodonika. Učešće ove grupe jedinjenja kretao se od $0,86 \%$, kod populacije P06, do 27,01\%, kod populacije P02. U etarskim uljima populacije $\mathbf{P 0 6}$ od 10 jedinjejna iz ove grupe ni jedno nije imalo 
značajnu zastupljenost, što je bio slučaj i kod populacija P01 (11 jedinjenja, 0,95\%), P04 (11 jedinjenja, 3,44\%), P03 (12 jedinjenja, 1,21\%), P09 (8 jedinjenja, 2,64\%) i P05 (13 jedinjenja, 6,56\%). Kod populacije P02 pojedinačno je jedino $\gamma$-terpinen imao koncentraciju od $21,39 \%$.

Oksigenovani monoterpenski ugljovodonici: Učešće ove grube jedinjenja u etarskim uljima ispitivanih populacija se kretalo od $0,27 \%$, kod populacije P04, pa do 88,60\% kod populacije P03 . Koncentracija oksigenovanih monoterpensjih ugljovodonika je bila visoka i kod populacija P06 $(87,47 \%)$ i P01 $(87,32 \%)$. Kod ove tri populacije najzastupljenija komponenta etarskih ulja bio je geraniol sa 87,92\% kod populacije sa P03, 87,12\% kod populacije P01 i 86,97\% kod populacije P06. U preostalim populacijama ni jedno iz ove grupe jedinjenja nije bilo zastupljeno u značajnijem procentu.

Seskviterpenski ugljovodonici: Ova grupa jedinjenja nije bila značajnije zastupljena u etarskim uljima ni jedne ispitivane populacije. Kod populacije P06 17 jedinjenja činilo je ukupno 8,93\%, kod populacije P01 19 jedinjenja činilo je ukupno 8,48\%, kod populacije P02 12 jedinjenja činilo je ukupno 7,53\%, kod populacije P03 10 jedinjenja činilo je ukupno 6,50\%, kod populacije P04 7 jedinjenja činilo je ukupno 6,27\%, kod populacije P05 10 jedinjenja činilo je ukupno i kod populacije P09 3 jedinjenja činilo je ukupno 3,69\%.

Ostala jedinjenja: Kod ispitivanih populacija Th. pulegioides utvrđeno je prisustvo 12 jedinjenja koja ne pripadaju ni jednoj od gore pomenutih grupa. Timol, koji je fenolno jedinjenje je glavna komponenta u etarskim uljima populacija P02 sa $52,95 \%$ i u etarskim uljima populacije P05 sa 62,92\%. Timol je značajno zastupljen i kod populacije P09 sa 22,12\%. Cimen, koji je aromatični ugljovodonik, je glavna komponenta etarskih ulja kod populacije P09 sa 48,59\% i P04 sa 42,59\% kod koje je značajno zastupleno i fenolno jedinjenje karvakrol sa 39,95\%. U etarskim uljima populacija P03, P01 i P06 ova jedinjenja nisu značajno zastupljena. 


\subsubsection{Sastav etarskih ulja Thymus glabrescens}

Kod sedam ispitivanih populacija Th. glabrescens u etarskim uljima je determinisano ukupno 73 jedinjenja, koja se mogu svrstati u tri osnovne grupe jedinjenja, monoterpenski ugljovodonici, sa 17 jedinjenja, oksigenovani monoterpenski ugljovodonici, sa 12 jedinjenja, i seskviterpenski ugljovodonic, sa 31 jedinjenjem. Takođe, utvrđeno je i prisustvo 11 jedinjenja koja ne pripadaju ni jednoj od ovih grupa (Tabela 3.2). Etarska ulja populacije P10 imala su 53 determinisane komponente, kod populacije P13 47, kod populacije P11 41, kod populacije P33 34, kod populacije P12 50, kod populacije P14 41 i populacije P15 31 komponenta.

Monoterpenski ugljovodonici: Kod ispitivanih populacija ove vrste determinisano je bilo 17 monoterpenskih ugljovodonika i njihova zastupljenost se kretala od 3,04\% kod populacije P33 do 37,08\% kod populacije P15. U etarskim uljima populacije P10 utvrđeno je prisustvo 15 monoterpenskih ugljovodonika (17,25\%) i jedino je $\gamma$-terpinen prisutan u značajnijoj koncentraciji od 11,91\%. Kod populacije P13 13 jedinjenja iz ove grupe činilo je ukupno 14,02\% etarskih ulja, a $\gamma$-terpinen je jedino jedinjenje sa značajnijom koncentracijom od 10,67\%. Kod populacije P11 determinisano je 16 komponenti iz ove grupe koje su činile 6,95\% etarskih ulja, pri čemu ni jedna komponenta nije imala značajniji procenat. Etarska ulja populacije P33 sadržala su 11 monoterpenskih ugljovodonika, koja su učestvovala sa 3,04\%. U etarskim uljima populacije P12 utvrđeno je prisustvo 14 jedinjenja iz ove grupe koja su činila 27,22\%, pri čemu je $\gamma$-terpinen bio zastupljen sa 19,61\%. Kod populacije P14 od 11 monoterpenskih ugljovodonika, koji su činili ukupno 18,55\%, $\gamma$-terpinen je bio najzastupljeniji sa 13,25\%. U etarskim uljima populacije P15 13 monoterpenskih ugljovodonika činilo je 37,08\% i $\gamma$-terpinen je bio druga po zastupljenosti komponenta sa $31,26 \%$.

Oksigenovani monoterpenski ugljovodonici: U etarskim uljima ispitivanih populacija Th. glabrescens utvrđeno je prisustvo ukupno 12 oksigenovanih monoterpenskih jedinjenja čija se zastupljenosst kretala od 1,38\%, kod populacije P13 (6 jedinjenja) do 7,06\% kod populacije P12 (8 jedinjenja). Ni jedno jedinjenje iz ove grupe nije imalo značajne procese, Kod populacije P10 8 jedinjenja iz ove grupe činilo je ukupno 3,33\%, kod populacije P11 4 jedinjenja iz ove grupe činila su 6,66\%, kod 
populacije P33 4 jedinjenja činila su 2,54\%, kod populacije P14 7 jedinjenja činilo je 4,93\% i kod populacije P15 4 jedinjenja ukupno 1,54\%.

Seskviterpenski ugljovodonici: Determinisano je ukupno 31 jedinjenje koje pripada ovoj grupi i njihova se zastupljenost kretala od 5,06\%, kod populacije P11 (11 jedinjenja) do 10,10\% kod populacije P13 (19 jedinjenja). U etarskim uljima ni jedne populacije pojedinačna jedinjenja iz ove grupe nisu imala značajniji procenat. U etarskim uljima populacije P10 18 seskvi terpenskih ugljovodonika činilo je 5,24\%, kod populacije P33 10 jedinjenja činilo je 7,27\%, kod populacije P12 19 jedinjenja činilo je 9,82\%, kod populacije P14 13 jedinjenja činilo je 6,85\% i kod populacije P15 7 jedinjenja činilo je 6,06\%.

Ostala jedinjenja: Kod ispitivanih populacija Th. glabrescens utvrđeno je prisustvo 13 jedinjenja koja ne pripadaju ni jednoj od gore pomenutih grupa. Timol, koji je fenolno jedinjenje je glavna komponenta u etarskim uljima populacija P10 (56,29\%), P13 (64,51\%), P11 (61,94\%) i P15 (44,53\%). Cimen, koji je aromatični ugljovodonik, je glavna komponenta etarskih ulja kod populacije P33 $(75,76 \%)$ i kod populacije P14 (42,56\%). Populacija P14 ima takođe i visoko učeše timola u etarskim uljima od 16,56\%. Etarska ulja populacije P12 sadrže 19,02\% timola, 18,43\% cimena i $13,11 \%$ timol metil etra.

\subsubsection{Sastav etraskih ulja Thymus marschallianus}

Kod tri ispitivane populacije vrste Th. marschallianus ustanovljeno je prisustvo ukupno 65 komponenata etarskih ulja. Prisutne su bile tri glavne grupe jedinjenja, monoterpenski ugljovodonici, sa 17 jedinjenja, oksigenovani monoterpenski ugljovodonici, sa 11 jedinjenja, i seskviterpenski ugljovodonic, sa 27 jedinjenja (Tabela 3.3). U etarskim uljima populacije P16 bilo je determinisano 45 komponenti, kod populacije iz Gtrebenca 53 komponente, a kod populacije P18 44 komponente.

Monoterpenski ugljovodonici: $U$ etarskim uljima ispitivanih populacija $T h$. marschallianus je utvrđeno prisustvo 17 monoterpenskih ugljovodonika. Njihova se zastupljenost kretala od 7,49\% kod populacije P17 do 20,04\% kod populcije P16. U etarskim uljima populacije $\mathbf{P 1 7}$ bilo je prisutno ukupno 11 monoterpenskih ugljovodonika, i jedino je silvestren imao značajniju koncentraciju od 3,75\%. Kod 
etarskih ulja populcije P18 od 11 monoterpenskih ugljovodonika činili su zajedno $14,38 \%$ i samo je $\alpha$-pinen bio prisutan u značajnom procentu $(11,29 \%)$. Kod populacije P16 bilo je prisutno 14 monoterpenskih ugljovodonika, pri čemu su (E)- $\beta$-Ocimen $(9,75 \%)$ i mircen $(4,75 \%)$ imali značajne koncentracije.

Oksigenovani monoterpenski ugljovodonici: Kod populacija Th. marschallianus, obuhvaćenih ispitivanjem, utvrđeno je prisustvo 11 oksigenovanih monoterpenski ugljovodonika čija se zastupljenost kretala od 3,58\% kod populacije P16 do $8,42 \%$ kod populacije P17. U etarskim uljima populacije P17 od ukupno 9 jedinjenja iz ove grupe ni jedno nije imalo neku značajniju koncentraciju, što je bio slučaj i od ukupno 6 jedinjenja kod populacije P16 tj. 7 kod populacije P18.

Seskviterpenski ugljovodonici: U etarskim uljima kod ispitivanih populacija Th. marschallianus, ova grupa jedinjenja je bila najzastupljenija. Prisustvo seskviterpenskih ugljovodonika se kretalo od 64,04\%, kod populacije P16, do 79,98\%, kod populacije P18. Kod populacije P17 bio je 67,50\%. Kod populacije P16 konstatovano je prisustvo 18 komponenti iz ove grupe i germakren-D je imao koncentraciju od 34\%, a biciklogermakren 12,30\%. Kod populacije P17 determinisano je 24 seskviterpenska ulgjovodonika i germakren-D je bio zastupljen sa 20,40\%, a značajnu koncentraciju je imao i (E)-kariofilen sa 14,57\%. Kod populacije P18, determinisano je 20 jedinjenja iz ove grupe i germakren-D je bio glavna komponenta sa zastupljenošću od $66,66 \%$.

Ostala jedinjenja: Kod tri ispitivane populacije Th. marschallianus, utvrđeno je prisustvo ukupno 10 jedinjenja koja nisu pripadala ni jednoj od prethodnih grupa. Ova jedinjenja su bila zastupljena u malom procentu kod sve tri populacija, od 1,82\%, kod populacije P18 do 8,52\% kod populacije P17 i 5,32\% kod populacije P16.

\subsubsection{Sastav etarskih ulja Thymus pannonicus}

Kod šest ispitivanih populacija vrste Th. pannonicus ustanovljeno je prisustvo ukupno 78 komponenata etarskih ulja. Prisutne su bile tri glavne grupe jedinjenja, monoterpenski ugljovodonici, sa 15 jedinjenja, oksigenovani monoterpenski ugljovodonici, sa 18 jedinjenja, i seskviterpenski ugljovodonic, sa 32 jedinjenja (Tabela 3.4). Etarska ulja populacije P21 sadržala su ukupno 40 komponenti, populacija iz 
Vršca, P19 i Ponorišta sadaržala su ukupno 41 komponentu, a kod populacija P20 i P22 49 komponenti.

Monoterpenski ugljovodonici: Kod popoulacija Th. pannonicus utvrđeno je prisustvo 15 različitih monoterpenskih ugljovodonika i njhova procentualna zastupljenost u etarskim uljim se kretala od 0,49\% kod populacije iz Vršca do 59,39\% kod populacije P19. U uljima populacije $\mathbf{P 2 3}$ determinisano je 9 jedinjenja iz ove grupe i sva su bila u koncentracijama ispod 1\% . Kod populacije P19 u etarskim uljima je bilo prisutno 14 monoterpenskih jedinjenja i ona su predstavljala glavnu grupu jedinjenja sa $59,39 \%$. Među njima najveću koncentraciju imao je $\alpha$-pinen sa $19.90 \%$, a slede ga (E)$\beta$-ocimen (14,24\%) i limonene (12,45\%). 14 monoterpenskih ugljovodonik sačinjavali su $32,45 \%$ etarskih ulja kod populacije P19, $\alpha$-pinen je činio 13,88\%, dok su miceren i (E)- $\beta$-ocimen činili 7,56\% i 5,61\%. Ostale komponente nisu prelazile 5\%. U etarskim uljima P22, prisutno je bilo 13 monoterpenskih ugljovodonika i ova grupa jedinjenja je činila $35,33 \%$ od ukupnog sastava, s time da je limonene predstavljao $24,82 \%$ a (E)- $\beta$ ocimen $6,56 \%$, dok ostale komponente nisu prelazile ni $1 \%$. Kod populacije P21 u etarskim uljim nalazilo se 14 monoterpenskih ugljo vodonika, koji su zajedno činili 7,93\%, pri čemu ni jedna komponenta nije prelazila 5\%. Kod populacije P34 prisutno je bilo 13 jedinjenja iz ove gruope, koja su zajedno činila 35,14\% ukupnih etarskih ulja, od kojih je samo miceren $(25,85 \%)$ imao značajnu koncentraciju.

Oksigenovani monoterpenski ugljovodonici: Kod ispitivanih populacija $T h$. pannonicus utvrđeno je prisustvo 18 oksigenovanih monoterpenskih ugljovodnika i njihova koncentracija se kretala od 2,58\% kod populacije P20 do $88,14 \%$ kod populacije P23. Kod populacije P23 nalazilo se 11 oksigenovanih monoterpenskih ugljovodonika i ovo je bila glavna grupa jedinjenja u etarskim uljima ove populacije, pri čemu izuzetno visoku koncentraciju su imali neral i geranijal, sa 34,05\% odnosno $51,74 \%$. Ostala jedinjenja iz ove grupe nisu prelazila $1 \%$. U etarskim uljima populacije P19 prisutno je bilo 5 jedinjenja iz ove grupe i jedino 1, 8-cineol $(8,21 \%)$ i kamfor (7,58\%) su imali značajnije koncentracije. Kod populacije P20 ovoj grupi jedinjenja je pripadalo 5 komponenti koje su zajedno činile 2,58\% etarskih ulja, pri čemu ni jedna komponenta nije dostizala niti 1\%. U etarskim uljima populacije P22 konstatovano je prisustvo 9 jedinjenja iz ove gupe i jedino je 1, 8-cineol imao značajniju koncentraciju od 5,65\%. Kod populacije P21 ova grupa jedinjenja je bila predstavljena sa 7 
komponenti i sa zastupljenošću od 75,61\% predstavljala je glavnu grupu jedinjenja. Linalool je bio prisutan u koncentraciji od 66,06\% i jedino je jos kamfor bio prisutan $u$ značajnijoj koncentraciji od 6,01\%. 5 oksigenovanih monoterpenskih ugljovodonika činili su 23,83\% etarskih ulja kod populacije P34, pri čemu je jedino $\alpha$-terpineol bio u značajnoj koncentraciji (20,01\%).

Seskviterpenski ugljovodonici: U etarskim uljimaetarskim uljima ispitivanih populacija Th. pannonicus utvrđeno je prisustvo 32 seskviterpenska ugljovodonika i njihovo učešće se kretalo od 1,85\% kod populacije P23 do 58,17\% kod populacije P20. Ukupno 13 jedinjenja iz ove grupe nalazilo se u etarskim uljima populacije P23 i ni jedno nije nije bilo zastupljeno u značajnom procentu. U etarskim uljima populacije P19 ova grupa jedinjenja je bila predstavljena sa 17 komponenti koje su zajedno činile 13,01\% ukupnih ulja, pri čemu ni jedna pojedinačna komponenta nije dostizala 5\%. Kod populacije P20 seskviterpenski ugljovodonici predstavljali su glavnu grupu jedinjenja i po broju komponenti, 22, i po zastupljenosti, 58,17\%, s time da je germakren-D bio glavna komponenta etarskih ulja sa 36,91\%. U etarskim uljima populacije P22 nalazilo se ukupno 19 seskviterpenskih ugljovodonika koj su zajedno činili 53,35\% i predstavljali glavnu grupu jedinjenja. Najzastupljeniji je bio $(E)$ kariofilen sa 40,30\% i jedino je još $\alpha$-humulen imao značajniju zastupljenost sa $6,15 \%$. Kod populacije P21, nalazilo se ukupno 14 jedinjenja iz ove grupe i činila su 14,09\% pri čemu je jedino $\beta$-biosabolen imao koncentraciju od 7,76\%. Kod populacije P34 determinisano je 19 jedinjenja iz ove grupe koja čine 35,63\% etarskih ulja, pri čemu dva jedinjenja imaju približno jednake koncentracije, (E)-kariofilen $(11,75 \%)$ i (E)- $\gamma$ bisabolen (11,93\%), dok je germakren-D zastupljen sa 6,29\%.

Ostala jedinjenja: U etarskim uljima kod šest ispitivanih populacija $T h$. pannonicus utvrđeno je bilo i prisustvo 13 komponenti koje ne pripadaju ni jednoj od prethodnih grupa jedinjenja i njihova ukupna zastupljenost se kretala od 0,36\% kod populacije P34 do 2,37\% kod populacije P23. Ni jedna pojedinačna komponenta nije imala značajniji procenat. 


\subsubsection{Sastav etarskih ulja Thymus balcanus}

U ispitivanje je bilo uključeno četiri populacije Th. balcanus u čijim je etarskim uljima bilo determinisano ukupno 60 komponenti (Tabela 3.5). Poulacija P25 je imala 46 determinisanih komponenti, populacija P26 49 komponenti, populacija P24 48, a populacija P27 33 komponente.

Monoterpenski ugljovodonici: Sadržaj ove grupe jedinjenja se kretao od 7,93\%, kod populacije Babinog zuba (12 komponenti), do 30,27\%, kod populacije P27 (12 komponenti). Kod populacije P24 13 monoterpenskih ugljovodonika u etarskim uljima činilo je 27, 37\%, a u etrarskim uljima popuulacije P26 14 komponenti je činilo 11,84\%. Pojedinačno je samo mircen bio značajno zastupljen i to $18,08 \% \mathrm{u}$ etarskim uljima populacije P24, 14,24\% u etarskim uljima populacije P27, 7,51\% u etarskim uljima populacije P26 i 4,26\% u etarskim uljima populacije $\mathbf{P 2 5}$.

Oksigenovani monoterpenski ugljovodonici: Kod ispitivanih populacija Th. balcanus sadržaj ove grupe jedinjenja se kretao od 43,46\%, kod populacije P24 gde je determinisano 12 ovih komponenti, do 60,22\%, kod populacije P27 gde je determinisano 8 jedinjenja iz ove grupe. U etarskim uljima populacije $\mathbf{P 2 5}$ utvrđeno je prisustvo 10 oksigenovanih monoterpenskih ugljo vodonika koji su ukupno činili 54,50\%, a kod populacije P26 12 jedinjenja iz ove grupe činilo je 53,30\% etarskih ulja. Kod populacije P25 značajnu kocentraciju, od jedinjenja koja pripadaju ovoj grupi, su imali geranial $(19,06 \%)$, neral $(12,70 \%)$ i neril acetat $(12,44 \%)$. U preostale tri populacije jedinjenja koja su bila sa značajnom koncentracijom su linalol i linalil acetat. Kod populacije P26 linalil acetat je imao koncentraciju od 33,89\% i bio je najzastupljenija komponenta etarsih ulja, dok je linalol imao koncentraciju od 17,05\%. Kod populacije P24 linalil acetat je sa 22,94\% takođe bio najzastupljenija komponenta etarskih ulja, dok je linalol imao koncentraciju od 11,74\%. Kod populacije P27 linalol je, sa 34,42\%, bio najzastupljenija komponenta, a linalil acetat je imao koncentraciju od $14,56 \%$.

Seskviterpenski ugljovodonici: Sadržaj seskviterpenskih ugljovodonika u etarskim uljim ispitivanih populacija Th. balcanus se kretao od 3,57\%, kod populacije P27 (9 jedinjenja), do 27,04\%, kod populacije P26 (17 jedinjenja). Kod populacije P24 17 jedinjenja iz ove grupe činilo je 21,01\% etarskih ulja, dok je 18 jedinjenja iz ove 
grup činilo 20,67\% etarskih ulja populacije P25. Od pojedinačnih komponenti, jedino je biciklogermakren imao koncentraciju od $11,88 \%$ u etarskim uljima populacije P26.

Ostala jedinjenja: Sadržaj ostalih jedinjenja u etarskim uljuima ispitivanih populacija je bio veoma nizak. Najveći je bio kod populacije P25, 11,73\%, dok je kod populacije P24 bio 2,73\%, kod populacije P26 0,88\% i kod populacije P27 0,83\%.

\subsubsection{Sastav etarskih ulja Thymus moesiacus}

U ispitivanja je bila uključena samo jedna populacija vrste Th. moesiacus, P31, u čijem su etarskom ulju determinisane 44 komponente tj. 98,04\% (Tabela 3.5).

Monoterpenski ugljovodonici: Ova grupa jedinjenja imala je 14 komponenti i činala je ukupno 13,91\%. Ni jedno jedinjenje iz ove grupe nije pojedinačno učestvovalo u značajnoj koncentraciji u sastavu etarskih ulja.

Oksigenovani monoterpenski ugljovodonici: U etarskim uljima ispitivane populacije Th. moesiacus determinisano je 11 jedinjenja iz ove grupe i ona su činila $81,97 \%$. Glavna komponenta etarskih ulja ove populacije je bio $\alpha$-terpinil acetat sa $66,59 \%$.

Seskviterpenski ugljovodonici: Ukupno 12 jedinjenja iz ove grupe činilo je svega $1,74 \%$ etarskih ulja ispitivane populacije.

Ostala jedinjenja: Ukupno 7 jedinjenja nije pripadalo ni jednoj od galvnih grupa i ona su zajedno činila $0,43 \%$ etarskih ulja ove populacije.

\subsubsection{Sastav etarskih ulja Thymus praecox}

U ova ispitivanja je bila uključena samo jedna populacija vrste Th. praecox, P32. Kod ove populacije determinisano je ukupno 47 komponenti koje su činile $88,98 \%$ etarskih ulja (Tabela 3.5).

Monoterpenski ugljovodonici: Ova grupa jedinjenja imala je 13 komponenti i činala je ukupno $12,33 \%$. Ni jedno jedinjenje iz ove grupe nije pojedinačno učestvovalo u značajnoj koncentraciji u sastavu etarskih ulja. 
Oksigenovani monoterpenski ugljovodonici: Ukupno 7 jedinjenja iz ove grupe činilo je 8,67\% etarskih ulja. Ni jedno jedinjenje pojedinačno nije imalo značajiju zastupljenost.

Seskviterpenski ugljovodonici: Ova grupa jedinjenja je bila najzastupljenija u etarskim uljima ispitivane populacije vrste Th. praecox. Determinisano je bilo ukupno 19 seskviterpenskih ugljovodonika koji su činili 62,96\% etarskih ulja. Najznačajnije komponente su bile $(E)$-kariofilen sa $20,48 \%, \gamma$-kadinen sa $17,84 \%$ i germakren-D sa $7,72 \%$.

Ostala jedinjenja: Kod ispitivane populacije Th. praecox utrvđeno je prisustvo 8 jedinjenja koja ne pripadaju ni jednoj od navedenih grupa i čine ukupno 5,02\% etarskih ulja i ni jedna pojedinačna komponenta nije zastupljena u značajnoj koncentraciji. 
Tabela 3.1 Sastav etarskog ulja Th. pulegioides.

\begin{tabular}{|c|c|c|c|c|c|c|c|c|c|}
\hline Jedinjenje & $\begin{array}{l}\text { KI } \\
\text { Literature }\end{array}$ & $\begin{array}{l}\text { Tip } \\
\text { jedinjenja }\end{array}$ & P01 & P02 & P03 & P04 & P05 & P06 & P09 \\
\hline Tricyclene & 927 & MH & - & 0.02 & 0.02 & - & - & - & - \\
\hline$\alpha$-Thujene & 930 & MH & 0.01 & 0.83 & 0.01 & 0.73 & 0.75 & - & 1.15 \\
\hline$\alpha$-Pinene & 939 & MH & 0.02 & 0.73 & 0.08 & 0.40 & 0.40 & 0.01 & 0.60 \\
\hline Camphene & 954 & MH & 0.03 & 0.76 & 0.15 & 0.04 & 0.05 & 0.01 & 0.25 \\
\hline Sabinene & 975 & MH & - & 0.02 & - & 0.02 & 0.02 & - & - \\
\hline$\beta$-Pinene & 979 & MH & - & 0.11 & 0.01 & 0.09 & 0.09 & - & 0.14 \\
\hline Myrcene & 991 & MH & 0.45 & 1.14 & 0.50 & 0.09 & 0.49 & 0.42 & 0.01 \\
\hline$\alpha$-Phellandrene & 1003 & MH & 0.03 & 0.19 & - & 0.04 & 0.09 & 0.04 & - \\
\hline$\alpha$-Terpinene & 1017 & MH & 0.02 & 1.45 & 0.02 & 0.51 & 0.73 & 0.02 & 0.10 \\
\hline Limonene & 1029 & MH & 0.08 & 0.17 & 0.09 & - & - & 0.06 & 0.12 \\
\hline$\beta$-Phellandrene & 1030 & MH & - & 0.08 & - & - & - & - & - \\
\hline Sylvestrene & 1031 & MH & - & - & - & - & 0.14 & - & - \\
\hline$(Z)-\beta$-Ocimene & 1037 & MH & 0.11 & 0.04 & 0.12 & 0.01 & 0.03 & 0.10 & - \\
\hline$(E)$ - $\beta$-Ocimene & 1050 & MH & 0.17 & 0.03 & 0.17 & - & 0.01 & 0.16 & - \\
\hline$\gamma$-Terpinene & 1060 & MH & 0.02 & 21.39 & 0.01 & 1.51 & 3.71 & 0.03 & 0.27 \\
\hline Terpinolene & 1089 & MH & 0.02 & 0.04 & 0.03 & 0.02 & 0.04 & 0.02 & - \\
\hline $\begin{array}{l}\text { cis-Dehydroxy-linalool } \\
\text { oxide }\end{array}$ & 1008 & OMHD & - & - & - & - & - & - & - \\
\hline (Z)-Sabinene hydrate & 1067 & OMHD & - & - & - & - & - & - & 0.11 \\
\hline $\begin{array}{l}\text { trans-Furanoid-linalool } \\
\text { oxide }\end{array}$ & 1073 & OMHD & - & - & - & - & - & - & - \\
\hline Linalool & 1097 & OMHD & 0.12 & 0.05 & - & - & - & 0.11 & 0.21 \\
\hline$\alpha$-Pinene oxide & 1099 & OMHD & - & 0.01 & 0.10 & 0.03 & 0.11 & 0.07 & 0.05 \\
\hline Camphor & 1146 & OMHD & - & - & 0.01 & - & - & - & -1 \\
\hline
\end{tabular}




\begin{tabular}{|c|c|c|c|c|c|c|c|c|c|}
\hline Jedinjenje & $\begin{array}{l}\text { KI } \\
\text { Literature }\end{array}$ & $\begin{array}{l}\text { Tip } \\
\text { jedinjenja }\end{array}$ & P01 & P02 & P03 & P04 & P05 & P06 & P09 \\
\hline$\beta$-Pinene oxide & 1159 & OMHD & 0.02 & - & - & - & - & - & - \\
\hline Borneol & 1169 & OMHD & 0.06 & 1.57 & 0.37 & 0.03 & 0.04 & 0.01 & 0.61 \\
\hline 3-Thujanol & 1169 & OMHD & - & - & 0.01 & 0.09 & 0.04 & - & - \\
\hline trans-Dihydro carvone & 1209 & OMHD & - & - & - & - & 0.01 & - & - \\
\hline Nerol & 1230 & OMHD & - & - & - & - & - & - & - \\
\hline Neral & 1238 & OMHD & - & - & - & - & - & - & - \\
\hline Thymoquinone & 1252 & OMHD & - & - & - & 0.11 & 3.09 & - & 5.49 \\
\hline Geraniol & 1253 & OMHD & 87.12 & - & 87.92 & - & - & 86.97 & - \\
\hline Geranial & 1267 & OMHD & - & - & - & - & - & - & - \\
\hline Bornyl acetate & 1289 & OMHD & - & 0.02 & 0.02 & - & - & - & 0.08 \\
\hline Methyl geranate & 1325 & OMHD & - & - & 0.18 & - & - & - & - \\
\hline Geranyl acetate & 1381 & OMHD & - & - & - & - & - & 0.31 & - \\
\hline Caryophyllene oxide & 1583 & $\mathbf{R}$ & 0.02 & 0.02 & - & 0.44 & 0.08 & - & - \\
\hline$p$-Cymene & 1025 & $\mathbf{R}$ & - & 4.89 & - & 42.59 & 17.36 & 0.01 & 48.59 \\
\hline$m$-Cymenene & 1085 & $\mathbf{R}$ & - & - & - & - & - & - & 0.04 \\
\hline p-Cymenene & 1091 & $\mathbf{R}$ & - & - & - & - & 0.03 & - & - \\
\hline 3-Octanone & 984 & $\mathbf{R}$ & 0.05 & 0.12 & 0.06 & 0.01 & 0.10 & 0.10 & 6.14 \\
\hline Thymol & 1290 & $\mathbf{R}$ & 0.05 & 52.95 & - & 0.05 & 62.82 & 0.07 & 22.12 \\
\hline Carvacrol & 1299 & $\mathbf{R}$ & - & 0.14 & - & 39.95 & 0.61 & - & 0.04 \\
\hline Thymohydroquinone & 1555 & $\mathbf{R}$ & - & - & - & 2.72 & 0.46 & - & - \\
\hline Thymol methyl ether & 1235 & $\mathbf{R}$ & - & 2.75 & - & 0.91 & 0.91 & - & 4.05 \\
\hline Carvacrol methyl ether & 1245 & $\mathbf{R}$ & - & 1.14 & - & - & 0.93 & 0.03 & 2.68 \\
\hline 3-Octanol & 991 & $\mathbf{R}$ & 0.35 & 0.04 & 0.11 & - & 0.03 & 1.10 & 0.63 \\
\hline Oct-1-en-3-ol & 979 & $\mathbf{R}$ & 0.39 & 1.19 & 0.26 & 0.20 & 1.14 & 0.05 & 0.95 \\
\hline Bergamol & 1057 & $\mathbf{R}$ & - & - & - & - & - & - & - \\
\hline
\end{tabular}




\begin{tabular}{|c|c|c|c|c|c|c|c|c|c|}
\hline Jedinjenje & $\begin{array}{l}\text { KI } \\
\text { Literature }\end{array}$ & $\begin{array}{l}\text { Tip } \\
\text { jedinjenja }\end{array}$ & P01 & P02 & P03 & P04 & P05 & P06 & P09 \\
\hline$\alpha$-Cubebene & 1351 & SH & 0.01 & - & - & - & - & 0.03 & - \\
\hline$\alpha$-Copaene & 1377 & SH & 0.02 & 0.01 & - & - & - & 0.01 & - \\
\hline$\beta$-Bourbonene & 1388 & SH & - & - & 0.03 & - & - & - & 0.09 \\
\hline$\alpha$-Bourbonene & 1390 & SH & 0.14 & 0.02 & - & 0.02 & 0.01 & 0.15 & - \\
\hline$\beta$-Elemene & 1391 & SH & 0.01 & - & - & - & - & - & - \\
\hline (E)-Caryophyllene & 1419 & SH & 2.71 & 0.86 & 1.87 & 6.00 & 0.66 & 0.19 & 0.19 \\
\hline$\beta$-Copaene & 1432 & SH & 0.03 & 0.01 & - & 0.01 & - & 0.02 & - \\
\hline trans- $\alpha$ Bergamotene & 1435 & SH & 0.02 & 0.02 & 0.03 & - & 0.01 & 0.03 & - \\
\hline Aromadendrene & 1441 & SH & - & - & - & - & - & 0.02 & - \\
\hline trans- $\beta$-Farnesene & 1443 & SH & - & - & - & - & 0.16 & 0.01 & - \\
\hline trans-Muurola-3,5 diene & 1454 & SH & 0.01 & - & 0.01 & - & - & - & - \\
\hline$\alpha$-Humulene & 1455 & SH & 0.27 & 0.04 & - & 0.14 & 0.04 & - & - \\
\hline Alloaromadendrene & 1460 & SH & 0.01 & - & 0.08 & - & - & 0.05 & - \\
\hline$\gamma$-Muurolene & 1480 & SH & 0.04 & 0.06 & - & - & - & - & - \\
\hline$\alpha$-Amorphene & 1485 & SH & - & 0.01 & - & 0.01 & - & - & - \\
\hline Germacrene-D & 1485 & SH & 1.69 & 0.02 & 0.08 & 0.02 & - & 0.55 & - \\
\hline$\gamma$-Amorphene & 1496 & SH & - & - & - & - & - & 0.02 & - \\
\hline Bicyclogermacrene & 1500 & SH & 0.01 & - & 0.10 & - & 0.01 & 0.46 & - \\
\hline$\alpha$-Muurolene & 1500 & SH & 0.02 & 0.01 & - & - & 0.01 & - & - \\
\hline$\beta$-Bisabolene & 1506 & SH & 3.40 & 6.47 & 4.24 & 0.08 & 3.70 & 7.28 & 3.41 \\
\hline$\delta$-Amorphene & 1512 & SH & - & - & - & - & - & 0.02 & - \\
\hline$\gamma$-Cadinene & 1514 & SH & 0.02 & - & - & - & - & - & - \\
\hline$\beta$-Sesquiphellandrene & 1523 & SH & 0.05 & - & 0.06 & - & 0.04 & 0.07 & - \\
\hline trans-Cadina-1,4 diene & 1535 & SH & 0.01 & - & - & - & - & - & - \\
\hline$\alpha$-Cadinene & 1539 & SH & 0.02 & - & - & - & - & - & - \\
\hline
\end{tabular}




\begin{tabular}{|l|l|l|r|r|r|r|r|r|r|}
\hline Jedinjenje & $\begin{array}{l}\text { KI } \\
\text { Literature }\end{array}$ & $\begin{array}{l}\text { Tip } \\
\text { jedinjenja }\end{array}$ & \multicolumn{1}{l|}{ P01 } & \multicolumn{1}{l}{ P02 } & \multicolumn{1}{l}{ P03 } & P04 & \multicolumn{1}{l}{ P05 } & P06 & P09 \\
\hline$\beta$-Atlantol & 1608 & SH & - & - & - & - & 0.01 & 0.02 & - \\
\hline \multicolumn{2}{l}{ Procenat determinacije } \\
\hline
\end{tabular}

KI - Kovačev indeks; MH - monoterpenski ugljovodonici; OMHD - oksigenovani monoterpenski ugljovodonici; R - ostala jedinjenja; SH - seskviterpenski ugljovodonici;

Tabela 3.2. Sastav etarskog ulja Th. glabrescens.

\begin{tabular}{|c|c|c|c|c|c|c|c|c|c|}
\hline & & & P10 & P11 & P12 & P13 & P14 & P15 & P33 \\
\hline Jedinjenje & $\begin{array}{l}\text { KI } \\
\text { Literature }\end{array}$ & $\begin{array}{l}\text { jedinje } \\
\text { nja }\end{array}$ & & & & & & & \\
\hline Tricyclene & 927 & MH & 0.02 & 0.04 & 0.06 & - & - & - & - \\
\hline$\alpha$-Thujene & 930 & MH & 0.98 & 0.73 & 1.28 & 0.56 & 1.35 & 0.98 & 0.76 \\
\hline$\alpha$-Pinene & 939 & MH & 0.64 & 0.78 & 1.46 & 0.34 & 1.00 & 0.39 & 0.39 \\
\hline Camphene & 954 & MH & 0.49 & 0.82 & 2.13 & 0.08 & 1.01 & 0.07 & 0.09 \\
\hline Sabinene & 975 & MH & 0.03 & 0.06 & 0.13 & 0.02 & 0.05 & 0.04 & 0.07 \\
\hline$\beta$-Pinene & 979 & MH & 0.18 & 0.17 & 0.30 & 0.08 & 0.18 & 0.14 & 0.14 \\
\hline Myrcene & 991 & MH & 1.26 & 0.58 & 0.80 & 1.00 & 0.45 & 1.21 & 0.05 \\
\hline$\alpha$-Phellandrene & 1003 & MH & 0.16 & 0.16 & 0.25 & 0.11 & 0.10 & 0.26 & 0.16 \\
\hline$\alpha$-Terpinene & 1017 & MH & 1.27 & 0.38 & 0.83 & 0.87 & 1.00 & 2.23 & 0.18 \\
\hline Limonene & 1029 & MH & 0.13 & 0.21 & 0.28 & 0.11 & 0.13 & 0.23 & 0.17 \\
\hline$\beta$-Phellandrene & 1030 & MH & 0.08 & 0.23 & - & 0.10 & - & 0.16 & - \\
\hline Sylvestrene & 1031 & MH & - & 0.66 & - & - & - & - & - \\
\hline$(Z)$ - $\beta$-Ocimene & 1037 & MH & - & 0.04 & - & 0.03 & - & - & - \\
\hline
\end{tabular}




\begin{tabular}{|c|c|c|c|c|c|c|c|c|c|}
\hline & & & $\mathbf{P 1 0}$ & P11 & P12 & P13 & P14 & P15 & P33 \\
\hline Jedinjenje & $\begin{array}{l}\text { KI } \\
\text { Literature }\end{array}$ & $\begin{array}{l}\text { jedinje } \\
\text { nja }\end{array}$ & & & & & & & \\
\hline Ocimene & 1043 & MH & - & 0.02 & - & - & - & - & - \\
\hline$(E)$ - $\beta$-Ocimene & 1050 & MH & 0.03 & - & 0.02 & - & - & 0.04 & - \\
\hline$\gamma$-Terpinene & 1060 & MH & 11.91 & 2.00 & 19.61 & 10.67 & 13.25 & 31.26 & 0.92 \\
\hline Terpinolene & 1089 & MH & 0.04 & 0.08 & 0.06 & 0.06 & 0.03 & 0.06 & 0.13 \\
\hline 1,8-Cineole & 1031 & $\begin{array}{l}\text { OMH } \\
\text { D }\end{array}$ & 1.13 & - & 1.05 & 0.15 & 0.26 & 1.27 & 0.40 \\
\hline (Z)-Sabinene hydrate & 1067 & $\begin{array}{l}\text { OMH } \\
\text { D }\end{array}$ & - & - & - & 0.30 & - & - & - \\
\hline Dehydro-linalool & 1091 & $\begin{array}{l}\text { OMH } \\
\text { D }\end{array}$ & 0.34 & - & - & - & - & - & - \\
\hline Linalool & 1097 & $\begin{array}{l}\text { OMH } \\
\text { D }\end{array}$ & - & - & 0.27 & 0.03 & 0.26 & - & - \\
\hline$\alpha$-Pinene oxide & 1099 & $\begin{array}{l}\text { OMH } \\
\text { D }\end{array}$ & 0.03 & - & 0.07 & 0.04 & 0.08 & 0.08 & 0.18 \\
\hline Camphor & 1146 & $\begin{array}{l}\text { OMH } \\
\text { D }\end{array}$ & 0.01 & - & 0.01 & - & - & - & - \\
\hline$\beta$-Pinene oxide & 1159 & $\begin{array}{l}\text { OMH } \\
\text { D }\end{array}$ & 0.02 & 0.12 & - & - & - & - & - \\
\hline Borneol & 1169 & $\begin{array}{l}\text { OMH } \\
\text { D }\end{array}$ & 0.66 & 1.51 & 3.36 & 0.12 & 2.33 & - & 0.12 \\
\hline 3-Thujanol & 1169 & $\begin{array}{l}\text { OMH } \\
\text { D }\end{array}$ & - & 0.20 & - & - & - & - & - \\
\hline$\alpha$-Terpineol & 1189 & $\begin{array}{l}\text { OMH } \\
\text { D }\end{array}$ & 0.04 & - & 0.08 & - & 0.04 & 0.07 & - \\
\hline Thymoquinone & 1252 & $\begin{array}{l}\text { OMH } \\
\text { D }\end{array}$ & 1.09 & 4.84 & 2.20 & 0.75 & 1.91 & 0.12 & 1.84 \\
\hline Bornyl acetate & 1289 & $\begin{array}{l}\text { OMH } \\
\text { D }\end{array}$ & - & - & 0.02 & - & 0.05 & - & - \\
\hline Elemol & 1550 & $\mathbf{R}$ & & - & - & - & - & - & - \\
\hline Spathulenol & 1578 & $\mathbf{R}$ & 0.14 & - & 0.28 & - & - & - & - \\
\hline
\end{tabular}




\begin{tabular}{|c|c|c|c|c|c|c|c|c|c|}
\hline & & & P10 & P11 & P12 & $\mathbf{P 1 3}$ & P14 & P15 & P33 \\
\hline Jedinjenje & $\begin{array}{l}\text { KI } \\
\text { Literature }\end{array}$ & $\begin{array}{l}\text { jedinje } \\
\text { nja }\end{array}$ & & & & & & & \\
\hline Caryophyllene oxide & 1583 & $\mathbf{R}$ & 0.05 & 0.03 & 0.06 & 0.05 & 0.08 & - & 0.14 \\
\hline$p$-Cymene & 1025 & $\mathbf{R}$ & 9.76 & 11.40 & 18.43 & 5.38 & 42.56 & 3.98 & 75.76 \\
\hline$m$-Cymenene & 1085 & $\mathbf{R}$ & 0.03 & - & - & - & - & - & - \\
\hline$p$-Cymenene & 1091 & $\mathbf{R}$ & - & - & - & - & - & - & 0.12 \\
\hline 3-Octanone & 984 & $\mathbf{R}$ & 0.36 & 0.09 & 0.46 & 0.19 & 0.14 & 2.09 & 0.37 \\
\hline Thymol & 1290 & $\mathbf{R}$ & 56.29 & 61.94 & 19.02 & 64.51 & 16.56 & 44.53 & 1.03 \\
\hline Carvacrol & 1299 & $\mathbf{R}$ & 0.04 & 0.02 & - & 0.04 & 0.01 & - & - \\
\hline Thymohydroquinone & 1555 & $\mathbf{R}$ & 0.05 & 0.09 & 0.06 & - & 0.43 & - & - \\
\hline Thymol methyl ether & 1235 & $\mathbf{R}$ & 1.21 & 2.06 & 13.11 & 1.23 & 4.93 & 0.63 & 3.89 \\
\hline Carvacrol methyl ether & 1245 & $\mathbf{R}$ & 2.49 & 2.46 & 1.65 & 1.82 & 1.52 & 1.04 & 1.10 \\
\hline 3-Octanol & 991 & $\mathbf{R}$ & 0.07 & 0.03 & - & 0.03 & 0.03 & 0.87 & 0.17 \\
\hline Oct-1-en-3-ol & 979 & $\mathbf{R}$ & 1.75 & 0.10 & 0.62 & 0.71 & 0.31 & 0.30 & 1.22 \\
\hline$\alpha$-Cubebene & 1351 & SH & - & - & 0.02 & - & 0.01 & - & - \\
\hline$\alpha$-Copaene & 1377 & SH & 0.03 & - & 0.03 & - & - & - & - \\
\hline$\alpha$-Bourbonene & 1390 & SH & 0.05 & 0.21 & 0.17 & 0.13 & 0.08 & - & 0.15 \\
\hline$\beta$-Elemene & 1391 & SH & 0.02 & - & - & 0.01 & - & - & - \\
\hline 7-epi-Sesquithujene & 1391 & SH & - & - & - & 0.06 & - & - & - \\
\hline$\alpha$-Funebrene & 1403 & SH & - & - & 0.03 & - & - & - & - \\
\hline$(E)$-Caryophyllene & 1419 & SH & 0.91 & 0.58 & 0.60 & 2.07 & 1.07 & 0.49 & 0.69 \\
\hline$\beta$-Copaene & 1432 & SH & 0.03 & 0.06 & 0.07 & 0.05 & 0.04 & - & 0.05 \\
\hline trans $-\alpha$ Bergamotene & 1435 & SH & 0.03 & 0.03 & 0.03 & 0.03 & 0.02 & 0.03 & 0.05 \\
\hline Aromadendrene & 1441 & SH & 0.19 & 0.07 & 0.03 & - & - & 0.09 & 0.04 \\
\hline trans- $\beta$-Farnesene & 1443 & SH & - & - & - & - & - & - & - \\
\hline trans-Muurola-3,5 diene & 1454 & SH & - & 0.03 & 0.02 & 0.01 & - & - & - \\
\hline
\end{tabular}




\begin{tabular}{|c|c|c|c|c|c|c|c|c|c|}
\hline & & & $\mathbf{P 1 0}$ & P11 & P12 & P13 & P14 & P15 & P33 \\
\hline Jedinjenje & $\begin{array}{l}\text { KI } \\
\text { Literature }\end{array}$ & jedinje & & & & & & & \\
\hline$\alpha$-Humulene & 1455 & SH & - & - & - & 0.09 & 0.04 & - & - \\
\hline Alloaromadendrene & 1460 & SH & 0.06 & - & 0.08 & 0.02 & - & - & 0.08 \\
\hline Dehydro-aromadendrene & 1463 & SH & - & 0.08 & - & - & - & 0.07 & - \\
\hline$\gamma$-Muurolene & 1480 & SH & 0.16 & 0.09 & 0.10 & 0.32 & 0.11 & 0.20 & 0.05 \\
\hline$\alpha$-Amorphene & 1485 & SH & - & - & - & 0.04 & - & - & - \\
\hline Germacrene-D & 1485 & SH & 0.03 & - & 0.69 & 0.01 & 0.14 & 0.24 & 0.07 \\
\hline$\gamma$-Amorphene & 1496 & SH & - & - & 0.08 & 0.08 & 0.03 & - & - \\
\hline Viridiflorene & 1497 & SH & 0.29 & - & - & - & - & - & - \\
\hline Bicyclogermacrene & 1500 & SH & - & 0.01 & 0.18 & - & - & - & - \\
\hline$\alpha$-Muurolene & 1500 & SH & 0.04 & - & - & 0.02 & 0.03 & - & - \\
\hline$(E, E)-\alpha$-Farnesene & 1506 & SH & - & - & - & 6.66 & - & - & - \\
\hline$\beta$-Bisabolene & 1506 & SH & 3.27 & 3.89 & 7.60 & - & 5.08 & 4.94 & 6.06 \\
\hline$\delta$-Amorphene & 1512 & SH & - & - & - & 0.37 & - & - & - \\
\hline$\gamma$-Cadinene & 1514 & SH & 0.04 & - & - & - & 0.03 & - & - \\
\hline$\beta$-Sesquiphellandrene & 1523 & SH & - & - & 0.05 & 0.07 & - & - & 0.04 \\
\hline$\delta$-Cadinene & 1523 & SH & 0.04 & - & - & - & 0.15 & - & - \\
\hline trans-Cadina-1,4 diene & 1535 & SH & 0.02 & - & 0.01 & 0.04 & - & - & - \\
\hline$\alpha$-Cadinene & 1539 & SH & 0.01 & - & 0.02 & 0.03 & - & - & - \\
\hline$\beta$-Atlantol & 1608 & SH & 0.02 & 0.01 & 0.02 & - & - & - & - \\
\hline \multicolumn{3}{|l|}{ Procenat determinacije } & 98.06 & 96.90 & 97.78 & 99.47 & 96.89 & 98.12 & 96.65 \\
\hline
\end{tabular}

KI - Kovačev indeks; MH - monoterpenski ugljovodonici; OMHD - oksigenovani monoterpenski ugljovodonici; R - ostala jedinjenja; SH - seskviterpensk ugljovodonici; 
Tabela 3.3 Sastav etarskog ulja Th. marschallianus.

\begin{tabular}{|c|c|c|c|c|c|}
\hline Jedinjenje & $\begin{array}{l}\text { KI } \\
\text { Literature }\end{array}$ & $\begin{array}{l}\text { Tip } \\
\text { jedinjenja }\end{array}$ & P16 & P17 & P18 \\
\hline Tricyclene & 927 & MH & 0.07 & - & . \\
\hline$\alpha$-Thujene & 930 & MH & 0.12 & 0.14 & 0.02 \\
\hline$\alpha$-Pinene & 939 & MH & 0.90 & 0.71 & 11.29 \\
\hline Camphene & 954 & MH & 1.81 & 0.13 & 0.29 \\
\hline Sabinene & 975 & MH & 0.13 & 0.24 & 0.11 \\
\hline$\beta$-Pinene & 979 & MH & 0.25 & 0.26 & 0.23 \\
\hline Myrcene & 991 & MH & 4.75 & 0.25 & 0.51 \\
\hline$\alpha$-Phellandrene & 1003 & MH & 0.15 & 0.13 & 0.13 \\
\hline$\alpha$-Terpinene & 1017 & MH & 0.06 & 0.09 & 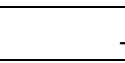 \\
\hline Limonene & 1029 & MH & 0.81 & - & 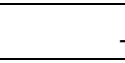 \\
\hline$\beta$-Phellandrene & 1030 & MH & - & - & - \\
\hline Sylvestrene & 1031 & MH & - & 3.75 & 0.95 \\
\hline$(Z)$ - $\beta$-Ocimene & 1037 & MH & 0.91 & 0.31 & 0.06 \\
\hline Ocimene & 1043 & MH & - & - & - \\
\hline$(E)$ - $\beta$-Ocimene & 1050 & MH & 9.75 & 1.48 & 0.75 \\
\hline$\gamma$-Terpinene & 1060 & MH & 0.24 & - & 0.05 \\
\hline Terpinolene & 1089 & MH & 0.09 & - & - \\
\hline 1,8-Cineole & 1031 & OMHD & 0.37 & 2.58 & 1.19 \\
\hline (Z)-Sabinene hydrate & 1067 & OMHD & 0.34 & 0.39 & 0.11 \\
\hline Linalool & 1097 & OMHD & 1.50 & 4.21 & 0.20 \\
\hline$\alpha$-Pinene oxide & 1099 & OMHD & 0.12 & 0.51 & 0.11 \\
\hline Camphor & 1146 & OMHD & 1.15 & - & 0.36 \\
\hline
\end{tabular}




\begin{tabular}{|c|c|c|c|c|c|}
\hline Jedinjenje & $\begin{array}{l}\text { KI } \\
\text { Literature }\end{array}$ & $\begin{array}{l}\text { Tip } \\
\text { jedinjenja }\end{array}$ & P16 & P17 & P18 \\
\hline Citronellal & 1153 & OMHD & - & 0.05 & - \\
\hline$\delta$-Terpineol & 1166 & OMHD & - & - & 0.05 \\
\hline$\alpha$-Terpineol & 1189 & OMHD & 0.10 & 0.20 & 0.16 \\
\hline cis-Dihydro carvone & 1203 & OMHD & - & 0.15 & - \\
\hline $\begin{array}{l}\text { trans-Dihydro } \\
\text { carvone }\end{array}$ & 1209 & OMHD & - & 0.06 & - \\
\hline Thymoquinone & 1252 & OMHD & - & 0.29 & - \\
\hline Elemol & 1550 & $\mathbf{R}$ & - & 0.29 & - \\
\hline Spathulenol & 1578 & $\mathbf{R}$ & 3.54 & - & - \\
\hline Caryophyllene oxide & 1583 & $\mathbf{R}$ & 0.17 & 5.45 & 0.10 \\
\hline$p$-Cymene & 1025 & $\mathbf{R}$ & 0.22 & 0.17 & 0.06 \\
\hline 3-Octanone & 984 & $\mathbf{R}$ & 0.39 & 0.44 & 0.25 \\
\hline Thymol & 1290 & $\mathbf{R}$ & 0.24 & 0.88 & 0.20 \\
\hline Carvacrol & 1299 & $\mathbf{R}$ & - & 0.06 & - \\
\hline Thymol methyl ether & 1235 & $\mathbf{R}$ & - & 0.16 & - \\
\hline 3-Octanol & 991 & $\mathbf{R}$ & 0.19 & 0.25 & 0.03 \\
\hline Oct-1-en-3-ol & 979 & $\mathbf{R}$ & 0.58 & 0.82 & 1.17 \\
\hline$\alpha$-Cubebene & 1351 & SH & 0.26 & 0.42 & 0.11 \\
\hline$\alpha$-Ylangene & 1375 & SH & 0.11 & 0.14 & 0.08 \\
\hline$\alpha$-Copaene & 1377 & SH & 0.35 & 1.10 & 0.33 \\
\hline$\beta$-Bourbonene & 1388 & SH & 2.59 & 9.17 & 2.31 \\
\hline$\alpha$-Bourbonene & 1390 & SH & - & 0.76 & 1.02 \\
\hline$\beta$-Elemene & 1391 & SH & 1.13 & 0.42 & - \\
\hline$(E)$-Caryophyllene & 1419 & SH & 4.03 & 14.57 & 2.53 \\
\hline$\beta$-Copaene & 1432 & SH & 0.80 & 1.46 & - \\
\hline
\end{tabular}




\begin{tabular}{|c|c|c|c|c|c|}
\hline Jedinjenje & $\begin{array}{l}\text { KI } \\
\text { Literature }\end{array}$ & $\begin{array}{l}\text { Tip } \\
\text { jedinjenja }\end{array}$ & P16 & $\mathbf{P 1 7}$ & P18 \\
\hline trans- $\alpha$ Bergamotene & 1435 & SH & - & 0.14 & 0.52 \\
\hline Aromadendrene & 1441 & SH & 1.13 & 0.88 & 0.04 \\
\hline $\begin{array}{l}\text { trans-Muurola-3,5 } \\
\text { diene }\end{array}$ & 1454 & SH & - & 0.40 & 0.51 \\
\hline$\alpha$-Humulene & 1455 & SH & - & 1.11 & 0.14 \\
\hline Alloaromadendrene & 1460 & SH & 0.84 & 1.68 & - \\
\hline $\begin{array}{l}\text { cis-Muurola-4(14),5- } \\
\text { diene }\end{array}$ & 1467 & SH & - & 0.81 & 0.85 \\
\hline$\gamma$-Muurolene & 1480 & SH & 0.81 & 1.17 & - \\
\hline Germacrene-D & 1485 & SH & 34.00 & 20.40 & 66.66 \\
\hline$\gamma$-Amorphene & 1496 & SH & - & 1.20 & 0.33 \\
\hline Viridiflorene & 1497 & SH & 1.02 & - & - \\
\hline Bicyclogermacrene & 1500 & SH & 12.30 & 0.49 & 0.18 \\
\hline$\alpha$-Muurolene & 1500 & SH & - & 1.04 & 0.16 \\
\hline$(E, E)-\alpha$-Farnesene & 1506 & SH & 1.99 & 1.50 & 2.35 \\
\hline$\gamma$-Cadinene & 1514 & SH & 0.93 & 2.78 & 0.55 \\
\hline $\begin{array}{l}\beta- \\
\text { Sesquiphellandrene }\end{array}$ & 1523 & SH & . & 2.7 & \\
\hline$\delta$-Cadinene & 1523 & SH & 1.33 & 4.60 & 0.98 \\
\hline trans-Calamenene & 1529 & SH & - & 0.42 & - \\
\hline $\begin{array}{l}\text { trans-Cadina-1,4 } \\
\text { diene }\end{array}$ & 1535 & SH & 0.18 & 0.86 & 0.08 \\
\hline$\alpha$-Cadinene & 1539 & SH & 0.26 & - & 0.25 \\
\hline \multicolumn{3}{|l|}{ Procenat determinacije } & 92.98 & 91.93 & 98.37 \\
\hline
\end{tabular}

KI - Kovačev indeks; MH - monoterpenski ugljovodonici; OMHD - oksigenovani monoterpenski ugljovodonici; R - ostala jedinjenja; SH - seskviterpenski ugljovodonici; 
Tabela 3.4. Sastav etarskog ulja Th. pannonicus.

\begin{tabular}{|c|c|c|c|c|c|c|c|c|}
\hline Jedinjenje & $\begin{array}{l}\text { Tip } \\
\text { jedinjenja }\end{array}$ & $\begin{array}{l}\text { KI } \\
\text { Literature }\end{array}$ & P19 & P20 & $\mathrm{P} 21$ & $\mathrm{P} 22$ & $\mathrm{P} 23$ & P34 \\
\hline Tricyclene & MH & 927 & 0.17 & 0.05 & 0.11 & - & - & 0.03 \\
\hline$\alpha$-Thujene & MH & 930 & 0.18 & 0.06 & 0.09 & 0.05 & - & 0.09 \\
\hline$\alpha$-Pinene & MH & 939 & 19.90 & 13.88 & 1.68 & 0.81 & 0.05 & 1.75 \\
\hline Camphene & MH & 954 & 4.03 & 1.11 & 3.28 & 0.06 & 0.07 & 0.77 \\
\hline Sabinene & MH & 975 & 0.58 & 0.16 & 0.21 & 0.37 & 0.03 & 1.09 \\
\hline$\beta$-Pinene & MH & 979 & 1.16 & 0.50 & 0.39 & 0.40 & 0.01 & 0.81 \\
\hline Myrcene & MH & 991 & 4.81 & 7.56 & 0.38 & 0.62 & 0.15 & 25.85 \\
\hline$\alpha$-Phellandrene & MH & 1003 & 0.38 & 0.17 & 0.04 & 0.08 & 0.08 & - \\
\hline$\alpha$-Terpinene & MH & 1017 & 0.16 & 0.05 & 0.04 & 0.03 & - & 0.03 \\
\hline Limonene & MH & 1029 & 12.45 & 1.98 & 0.26 & 24.82 & 0.02 & 0.73 \\
\hline$(Z)$ - $\beta$-Ocimene & MH & 1037 & 0.93 & 1.14 & 0.44 & 1.38 & - & 0.98 \\
\hline Ocimene & MH & 1043 & - & - & 0.92 & - & - & - \\
\hline (E)- $\beta$-Ocimene & MH & 1050 & 14.24 & 5.61 & - & 6.56 & - & 2.89 \\
\hline$\gamma$-Terpinene & MH & 1060 & 0.16 & 0.15 & 0.05 & 0.14 & 0.03 & 0.07 \\
\hline Terpinolene & MH & 1089 & 0.23 & 0.02 & 0.04 & 0.02 & 0.04 & 0.05 \\
\hline 1,8-Cineole & OMHD & 1031 & 8.21 & 0.75 & 2.73 & 5.65 & 0.14 & 1.29 \\
\hline (Z)-Sabinene hydrate & OMHD & 1067 & - & 0.27 & - & 0.26 & 0.22 & - \\
\hline Linalool & OMHD & 1097 & - & 0.77 & 66.06 & 0.03 & 0.04 & 0.22 \\
\hline$\alpha$-Pinene oxide & OMHD & 1099 & 0.42 & 0.16 & - & 0.15 & 0.31 & 2.27 \\
\hline Camphor & OMHD & 1146 & 7.58 & 0.59 & 6.01 & 0.15 & 0.11 & - \\
\hline Citronellal & OMHD & 1153 & - & - & - & - & 0.05 & - \\
\hline
\end{tabular}




\begin{tabular}{|c|c|c|c|c|c|c|c|c|}
\hline Jedinjenje & $\begin{array}{l}\text { Tip } \\
\text { jedinjenja }\end{array}$ & $\begin{array}{l}\text { KI } \\
\text { Literature }\end{array}$ & P19 & $\mathrm{P} 20$ & $\mathrm{P} 21$ & $\mathrm{P} 22$ & $\mathrm{P} 23$ & P34 \\
\hline$\beta$-Pinene oxide & OMHD & 1159 & - & - & - & - & 0.95 & - \\
\hline Borneol & OMHD & 1169 & - & - & 0.20 & - & - & 0.03 \\
\hline 3-Thujanol & OMHD & 1169 & 0.94 & - & - & - & - & - \\
\hline$\alpha$-Terpineol & OMHD & 1189 & 0.13 & - & 0.25 & - & 0.06 & 20.01 \\
\hline cis-Dihydro carvone & OMHD & 1203 & - & - & - & 0.12 & - & - \\
\hline $\begin{array}{l}\text { trans-Dihydro } \\
\text { carvone }\end{array}$ & OMHD & 1209 & - & - & - & 0.18 & - & - \\
\hline Neral & OMHD & 1238 & - & - & - & - & 34.05 & - \\
\hline Thymoquinone & OMHD & 1252 & - & 0.05 & - & - & - & - \\
\hline Geraniol & OMHD & 1253 & - & - & - & 0.62 & - & - \\
\hline Geranial & OMHD & 1267 & - & - & 0.02 & - & 51.74 & - \\
\hline Bornyl acetate & OMHD & 1289 & - & - & 0.32 & - & - & - \\
\hline Neryl acetate & OMHD & 1362 & - & - & - & 0.07 & 0.46 & - \\
\hline Spathulenol & OMHD & 1578 & - & - & - & - & 0.14 & - \\
\hline Caryophyllene oxide & OMHD & 1583 & - & 0.19 & 0.03 & 1.00 & - & - \\
\hline$p$-Cymene & $\mathbf{R}$ & 1025 & - & 0.14 & - & 0.07 & 0.09 & - \\
\hline$p$-Cymenene & $\mathbf{R}$ & 1091 & - & - & - & - & 0.06 & - \\
\hline 3-Octanone & $\mathbf{R}$ & 984 & 0.15 & 0.29 & 0.16 & 0.12 & - & 0.07 \\
\hline Thymol & $\mathbf{R}$ & 1290 & 0.21 & 0.24 & 0.08 & 0.12 & 0.05 & - \\
\hline Carvacrol & $\mathbf{R}$ & 1299 & - & - & - & - & 0.03 & 0.08 \\
\hline Thymol methyl ether & $\mathbf{R}$ & 1235 & 0.19 & 0.03 & - & 0.10 & - & - \\
\hline $\begin{array}{l}\text { Carvacrol methyl } \\
\text { ether }\end{array}$ & $\mathbf{R}$ & 1245 & - & - & 0.05 & 0.03 & - & - \\
\hline 3-Octanol & $\mathbf{R}$ & 991 & 0.17 & 0.35 & - & 0.08 & - & 0.03 \\
\hline Oct-1-en-3-ol & $\mathbf{R}$ & 979 & 0.81 & 1.11 & 0.25 & 0.83 & 1.43 & 0.17 \\
\hline
\end{tabular}




\begin{tabular}{|c|c|c|c|c|c|c|c|c|}
\hline Jedinjenje & $\begin{array}{l}\text { Tip } \\
\text { jedinjenja }\end{array}$ & $\begin{array}{l}\text { KI } \\
\text { Literature }\end{array}$ & P19 & $\mathrm{P} 20$ & $\mathrm{P} 21$ & $\mathrm{P} 22$ & $\mathrm{P} 23$ & P34 \\
\hline Bergamol & $\mathbf{R}$ & 1057 & - & - & - & - & 0.02 & - \\
\hline $\begin{array}{l}\text { 6-methyl-5-hepten-2- } \\
\text { one }\end{array}$ & $\mathbf{R}$ & 986 & - & - & - & - & 0.55 & - \\
\hline$\alpha$-Cubebene & SH & 1351 & 0.13 & 0.13 & - & 0.04 & - & 0.03 \\
\hline$\alpha$-Ylangene & SH & 1375 & - & 0.06 & - & - & - & - \\
\hline$\alpha$-Copaene & SH & 1377 & 0.22 & 0.39 & - & 0.11 & - & 0.07 \\
\hline$\beta$-Bourbonene & SH & 1388 & - & - & - & - & 0.22 & - \\
\hline$\alpha$-Bourbonene & SH & 1390 & 0.51 & 2.46 & - & 0.68 & - & 0.28 \\
\hline$\beta$-Elemene & SH & 1391 & 0.12 & 0.72 & - & 0.23 & 0.02 & 0.16 \\
\hline (E)-Caryophyllene & SH & 1419 & 1.33 & 4.16 & 1.92 & 40.30 & 0.08 & 11.75 \\
\hline$\beta$-Cedrene & SH & 1421 & - & - & 0.05 & - & - & - \\
\hline$\beta$-Copaene & SH & 1432 & 0.21 & 0.59 & - & 0.11 & 0.03 & 0.07 \\
\hline trans- $\alpha$ Bergamotene & SH & 1435 & - & - & 0.05 & - & - & 0.05 \\
\hline Aromadendrene & SH & 1441 & - & 0.10 & - & - & - & - \\
\hline trans- $\beta$-Farnesene & SH & 1443 & - & - & - & - & 0.21 & - \\
\hline $\begin{array}{l}\text { trans-Muurola-3,5 } \\
\text { diene }\end{array}$ & SH & 1454 & 0.09 & 0.41 & 0.32 & 0.07 & 0.02 & 0.04 \\
\hline$\alpha$-Humulene & SH & 1455 & - & - & 0.49 & 6.15 & - & 3.32 \\
\hline$(E)$ - $\beta$-Farnesene & SH & 1457 & 2.73 & 6.96 & - & - & - & - \\
\hline Alloaromadendrene & SH & 1460 & - & - & 0.05 & - & 0.03 & 0.02 \\
\hline $\begin{array}{l}\text { cis-Muurola-4(14),5- } \\
\text { diene }\end{array}$ & SH & 1467 & - & 0.89 & 0.48 & 0.08 & - & - \\
\hline$\gamma$-Muurolene & SH & 1480 & 0.45 & 0.54 & 0.02 & 0.10 & 0.03 & - \\
\hline Germacrene-D & SH & 1485 & 4.60 & 36.91 & 0.23 & 3.94 & 0.54 & 6.29 \\
\hline$\gamma$-Amorphene & SH & 1496 & 0.28 & 0.27 & - & 0.20 & - & 0.15 \\
\hline Bicyclogermacrene & SH & 1500 & 0.18 & 0.21 & 0.25 & 0.05 & - & 0.39 \\
\hline
\end{tabular}




\begin{tabular}{|c|c|c|c|c|c|c|c|c|}
\hline Jedinjenje & $\begin{array}{l}\text { Tip } \\
\text { jedinjenja }\end{array}$ & $\begin{array}{l}\text { KI } \\
\text { Literature }\end{array}$ & P19 & $\mathrm{P} 20$ & $\mathrm{P} 21$ & $\mathrm{P} 22$ & $\mathrm{P} 23$ & P34 \\
\hline$\alpha$-Muurolene & SH & 1500 & 0.19 & 0.24 & - & 0.08 & 0.08 & 0.06 \\
\hline$(E, E)-\alpha$-Farnesene & SH & 1506 & 0.47 & 0.18 & - & 0.50 & 0.23 & 0.48 \\
\hline$\beta$-Bisabolene & SH & 1506 & 0.57 & 0.27 & 7.76 & - & 0.33 & 0.20 \\
\hline$\delta$-Amorphene & SH & 1512 & - & - & - & - & 0.04 & 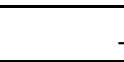 \\
\hline$\gamma$-Cadinene & SH & 1514 & - & 0.75 & 2.24 & 0.21 & - & 0.23 \\
\hline $\begin{array}{l}\beta- \\
\text { Sesquiphellandrene }\end{array}$ & SH & 1523 & - & - & 0.14 & - & - & 0.12 \\
\hline$\delta$-Cadinene & SH & 1523 & - & 1.48 & - & 0.39 & - & 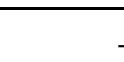 \\
\hline trans-Calamenene & SH & 1529 & 0.51 & - & - & - & - & - \\
\hline $\begin{array}{l}\text { (E)-gamma- } \\
\text { Bisabolene }\end{array}$ & SH & 1531 & & - & - & - & - & 11.93 \\
\hline $\begin{array}{l}\text { trans-Cadina-1,4 } \\
\text { diene }\end{array}$ & SH & 1535 & - & 0.10 & - & 0.04 & - & \\
\hline$\alpha$-Cadinene & SH & 1539 & 0.42 & 0.35 & 0.07 & 0.07 & - & 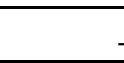 \\
\hline \multicolumn{3}{|c|}{ Procenat determinacije } & 91.22 & 95.55 & 98.20 & 98.24 & 92.85 & 94.96 \\
\hline
\end{tabular}

KI - Kovačev indeks; MH - monoterpenski ugljovodonici; OMHD - oksigenovani monoterpenski ugljovodonici; R - ostala jedinjenja; SH - seskviterpenski ugljovodonici; 
Tabela 3.5 Sastav etarskog ulja populacija vrsta iz podsekcije Pseudomarginati.

\begin{tabular}{|c|c|c|c|c|c|c|c|c|}
\hline Jedinjenje & $\begin{array}{l}\text { KI } \\
\text { Literature }\end{array}$ & $\begin{array}{l}\text { Tip } \\
\text { jedinjenja }\end{array}$ & P24 & P25 & P26 & P27 & P31 & P32 \\
\hline Tricyclene & 927 & MH & - & - & 0.06 & - & 0.06 & - \\
\hline$\alpha$-Thujene & 930 & MH & 0.09 & 0.07 & 0.07 & - & 0.15 & 0.36 \\
\hline$\alpha$-Pinene & 939 & MH & 0.77 & 0.95 & 1.41 & 0.14 & 1.27 & 1.62 \\
\hline Camphene & 954 & MH & 0.98 & 0.95 & 1.22 & 0.07 & 2.59 & 1.28 \\
\hline Sabinene & 975 & MH & 0.23 & 0.16 & 0.06 & 0.05 & 1.58 & 0.41 \\
\hline$\beta$-Pinene & 979 & MH & 0.31 & 0.26 & 0.23 & 0.06 & 0.22 & 0.48 \\
\hline Myrcene & 991 & MH & 18.08 & 4.26 & 7.51 & 14.24 & 4.06 & 3.02 \\
\hline$\alpha$-Phellandrene & 1003 & MH & 0.25 & 0.09 & 0.07 & 0.24 & 0.05 & 0.17 \\
\hline$\alpha$-Terpinene & 1017 & MH & 0.18 & - & 0.05 & 0.22 & 0.15 & 0.35 \\
\hline Limonene & 1029 & MH & 0.92 & 0.72 & 0.34 & 3.15 & 2.95 & 0.66 \\
\hline$(Z)$ - $\beta$-Ocimene & 1037 & MH & 1.79 & 0.05 & 0.31 & 3.79 & - & 0.15 \\
\hline$(E)$ - $\beta$-Ocimene & 1050 & MH & 3.14 & 0.32 & 0.40 & 7.43 & 0.01 & 0.89 \\
\hline$\gamma$-Terpinene & 1060 & MH & 0.37 & 0.05 & 0.04 & 0.21 & 0.50 & 2.86 \\
\hline Terpinolene & 1089 & MH & 0.29 & 0.04 & 0.08 & 0.67 & 0.33 & 0.08 \\
\hline 1.8-Cineole & 1031 & OMHD & 1.47 & 1.62 & 0.07 & 0.43 & 0.05 & 3.43 \\
\hline $\begin{array}{l}\text { (Z)-Sabinene } \\
\text { hydrate }\end{array}$ & 1067 & OMHD & 0.51 & 0.29 & 0.19 & 0.19 & 1.19 & 1.23 \\
\hline Linalool & 1097 & OMHD & 11.74 & - & 17.05 & 34.42 & - & 0.70 \\
\hline$\alpha$-Pinene oxide & 1099 & OMHD & 0.28 & 0.26 & 0.08 & 0.80 & 0.03 & 0.61 \\
\hline Camphor & 1146 & OMHD & 1.67 & 0.14 & 1.47 & - & 0.01 & 0.06 \\
\hline$\beta$-Pinene oxide & 1159 & OMHD & - & 0.70 & - & - & & - \\
\hline Borneol & 1169 & OMHD & 0.19 & - & 0.07 & 0.10 & 0.55 & 1.54 \\
\hline 3-Thujanol & 1169 & OMHD & - & - & - & - & 0.15 & - \\
\hline
\end{tabular}




\begin{tabular}{|c|c|c|c|c|c|c|c|c|}
\hline Jedinjenje & $\begin{array}{l}\text { KI } \\
\text { Literature }\end{array}$ & $\begin{array}{l}\text { Tip } \\
\text { jedinjenja }\end{array}$ & P24 & $\mathbf{P} 25$ & P26 & P27 & P31 & P32 \\
\hline$\alpha$-Terpineol & 1189 & OMHD & - & - & - & - & 5.81 & - \\
\hline $\begin{array}{l}\text { trans-Dihydro } \\
\text { carvone }\end{array}$ & 1209 & OMHD & - & - & - & - & 0.02 & - \\
\hline Linalyl formate & 1216 & OMHD & - & - & 0.02 & - & - & - \\
\hline Neral & 1238 & OMHD & 0.07 & 12.70 & 0.02 & - & - & - \\
\hline Carvone & 1243 & OMHD & - & - & - & - & 0.07 & - \\
\hline Thymoquinone & 1252 & OMHD & - & - & - & - & - & 1.10 \\
\hline Geraniol & 1253 & OMHD & - & 2.57 & - & - & - & - \\
\hline Linalyl acetate & 1257 & OMHD & 22.94 & - & 33.89 & 14.56 & - & - \\
\hline Geranial & 1267 & OMHD & - & 19.06 & - & - & - & - \\
\hline Isobornyl acetate & 1286 & OMHD & 0.08 & - & 0.06 & - & - & - \\
\hline Bornyl acetate & 1289 & OMHD & 0.11 & - & 0.06 & - & 7.50 & - \\
\hline $\begin{array}{l}\text { alpha-Terpinyl } \\
\text { acetate }\end{array}$ & 1349 & OMHD & - & - & - & - & 66.59 & - \\
\hline Neryl acetate & 1362 & OMHD & 1.38 & 12.44 & - & 3.08 & - & - \\
\hline Geranyl acetate & 1381 & OMHD & 3.01 & 4.72 & 0.31 & 6.64 & - & - \\
\hline Elemol & 1550 & $\mathbf{R}$ & - & 5.96 & - & - & - & - \\
\hline $\begin{array}{l}\text { Caryophyllene } \\
\text { oxide }\end{array}$ & 1583 & $\mathbf{R}$ & 0.18 & 0.16 & 0.07 & - & 0.07 & 1.19 \\
\hline$p$-Cymene & 1025 & $\mathbf{R}$ & 0.15 & - & 0.03 & - & 0.27 & 1.73 \\
\hline$p$-Cymenene & 1091 & $\mathbf{R}$ & - & - & - & - & 0.03 & - \\
\hline 3-Octanone & 984 & $\mathbf{R}$ & 0.18 & 0.62 & 0.07 & 0.06 & 0.01 & 0.06 \\
\hline Thymol & 1290 & $\mathbf{R}$ & 0.07 & 0.26 & 0.14 & 0.10 & 0.04 & 0.38 \\
\hline $\begin{array}{l}\text { Thymol methyl } \\
\text { ether }\end{array}$ & 1235 & $\mathbf{R}$ & - & 3.35 & - & - & - & 1.03 \\
\hline $\begin{array}{l}\text { Carvacrol methyl } \\
\text { ether }\end{array}$ & 1245 & $\mathbf{R}$ & - & - & - & - & & 0.26 \\
\hline
\end{tabular}




\begin{tabular}{|c|c|c|c|c|c|c|c|c|}
\hline Jedinjenje & $\begin{array}{l}\text { KI } \\
\text { Literature }\end{array}$ & $\begin{array}{l}\text { Tip } \\
\text { jedinjenja }\end{array}$ & P24 & P25 & P26 & P27 & P31 & P32 \\
\hline 3-Octanol & 991 & $\mathbf{R}$ & 0.19 & - & 0.09 & 0.32 & - & 0.10 \\
\hline Oct-1-en-3-ol & 979 & $\mathbf{R}$ & 1.97 & 1.39 & 0.49 & 0.35 & - & 0.27 \\
\hline$\alpha$-Cubebene & 1351 & SH & 0.25 & 0.07 & 0.16 & 0.40 & - & - \\
\hline$\alpha$-Ylangene & 1375 & SH & 0.12 & - & 0.07 & - & - & - \\
\hline$\alpha$-Copaene & 1377 & SH & 0.10 & 0.16 & 0.20 & 0.14 & - & 0.21 \\
\hline$\alpha$-Bourbonene & 1390 & SH & 0.16 & - & 0.05 & 0.28 & 0.03 & 0.66 \\
\hline$\beta$-Elemene & 1391 & SH & 0.22 & 0.21 & 0.28 & - & - & 0.44 \\
\hline$(E)$-Caryophyllene & 1419 & SH & 9.85 & 6.66 & 4.93 & - & 1.05 & 20.48 \\
\hline$\beta$-Copaene & 1432 & SH & - & 0.06 & - & - & 0.01 & 0.16 \\
\hline $\begin{array}{l}\text { trans- } \alpha \\
\text { Bergamotene }\end{array}$ & 1435 & SH & - & - & - & - & 0.03 & - \\
\hline Aromadendrene & 1441 & SH & 0.06 & 0.18 & 0.09 & 0.87 & 0.01 & 0.09 \\
\hline $\begin{array}{l}\text { trans-Muurola-3.5 } \\
\text { diene }\end{array}$ & 1454 & SH & 0.06 & 0.24 & 0.11 & - & - & 1.35 \\
\hline$\alpha$-Humulene & 1455 & SH & - & 0.44 & - & - & 0.04 & 7.92 \\
\hline (E)- $\beta$-Farnesene & 1457 & SH & 6.00 & - & 2.26 & 0.10 & - & - \\
\hline Alloaromadendrene & 1460 & SH & 0.53 & 0.82 & 1.70 & 0.27 & - & - \\
\hline$\alpha$-Amorphene & 1485 & SH & 0.16 & 0.10 & 0.37 & 0.81 & - & 0.36 \\
\hline Germacrene-D & 1485 & SH & 0.94 & 0.87 & 1.88 & - & 0.07 & 7.72 \\
\hline$\gamma$-Amorphene & 1496 & SH & - & 0.22 & - & - & - & 0.27 \\
\hline $\begin{array}{l}\text { cis-Cadina-1.4- } \\
\text { diene }\end{array}$ & 1496 & SH & - & - & - & 0.13 & - & $\pi$ \\
\hline Bicyclogermacrene & 1500 & SH & 1.13 & 3.38 & 11.88 & 0.56 & 0.19 & 2.34 \\
\hline$\alpha$-Muurolene & 1500 & SH & - & - & - & - & - & 0.27 \\
\hline$(E . E)$ - $\alpha$-Farnesene & 1506 & SH & - & 3.35 & - & - & - & 0.74 \\
\hline$\beta$-Bisabolene & 1506 & SH & - & 0.07 & - & - & 0.31 & 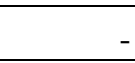 \\
\hline
\end{tabular}




\begin{tabular}{|l|l|l|r|r|r|r|r|r|}
\hline & $\begin{array}{l}\text { KI } \\
\text { Jedinjenje }\end{array}$ & $\begin{array}{l}\text { Tip } \\
\text { jedinjenja }\end{array}$ & P24 & P25 & P26 & P27 & P31 & P32 \\
\hline$\delta$-Amorphene & 1512 & SH & 0.11 & - & 0.35 & - & - & - \\
\hline$\gamma$-Cadinene & 1514 & SH & 0.40 & 2.90 & 0.80 & - & - & 17.84 \\
\hline $\begin{array}{l}\beta- \\
\text { Sesquiphellandrene }\end{array}$ & 1523 & SH & - & - & - & - & - & - \\
\hline$\delta$-Cadinene & 1523 & SH & 0.88 & 0.82 & 1.81 & - & - & - \\
\hline trans-Calamenene & 1529 & SH & - & - & - & - & - & 1.03 \\
\hline $\begin{array}{l}\text { trans-Cadina-1.4 } \\
\text { diene }\end{array}$ & 1535 & SH & 0.06 & - & 0.11 & - & - & 0.10 \\
\hline$\alpha$-Cadinene & 1539 & SH & - & 0.11 & - & - & - & 0.60 \\
\hline$\beta$-Atlantol & 1608 & SH & - & - & - & - & 0.01 & 0.39 \\
\hline Procenat determinacije & & & 94.57 & & 93.06 & 94.90 & 98.04 & 88.98 \\
\hline
\end{tabular}

KI - Kovačev indeks; MH - monoterpenski ugljovodonici; OMHD - oksigenovani monoterpenski ugljovodonici; R - ostala jedinjenja; SH - seskviterpenski ugljovodonici; 


\subsubsection{Statistička obrada sastava etarskih ulja}

\section{Statistička obrada sastava etarskih ulja podsekcije Alternantes}

Pearsonov koeficijent korelacije za pet sastojaka etarskog ulja koji prelaze 10\%, dat je u tabeli 3.6. Iz tabele se vidi da ni u jednom slučaju ne postoji statisticki znacajna korelacija $(\mathrm{P}<0,5)$ između posmatranih sastojaka.

Tabela 3.6 Korelacije između pet najzastupljenijih komponenti etarskog ulja podsekcije Alternantes

\begin{tabular}{|c|c|c|c|c|c|}
\hline & $\mathrm{p}$-Cimen & $\gamma$ - pinen & geraniol & Timol & Karvakrol \\
\hline$p$-Cimen & 1,00 & $\mathrm{~ns}$ & $\mathrm{~ns}$ & $\mathrm{~ns}$ & $\mathrm{~ns}$ \\
\hline$\gamma$-pinen & $-0,19$ & 1,00 & $\mathrm{~ns}$ & $\mathrm{~ns}$ & $\mathrm{~ns}$ \\
\hline geraniol & $-0,72$ & $-0,46$ & 1,00 & $\mathrm{~ns}$ & $\mathrm{~ns}$ \\
\hline Timol & 0,05 & 0,65 & $-0,67$ & 1,00 & $\mathrm{~ns}$ \\
\hline Karvakrol & 0,55 & $-0,13$ & $-0,36$ & $-0,30$ & 1,00 \\
\hline
\end{tabular}

ns - nema znacaj, $*(0.05<\mathrm{p}<0.01), * *(\mathrm{p}<0.01)$

Analiza glavnih komponenti (PCA) pokazala je da su dve glavne komponente imale utvrđenu sopstvenu vrednost (eigenvalues) veću od 1,0 i da su zajedno objašnjavale $84,23 \%$ ukupne varijanse (Tabela 3.7). Na grafiku 3.1 prikazan je biplot na temelju prve i druge ose. Na grafiku se vidi da je PC1 razdvajala populacije bogate geraniolom od ostalih i da je PC2 radvajala one koje su imale visoku koncentraciju timola i $\gamma$-terpinena od onih bogatih karvakrolom i $p$-cimenom. 
Grafik 3.1 Biplot dobijen Analizom glavnih komponenti na osnovu pet najzastupljenija jedinjenja etarskog ulja analizirane kod podsekcije Alternantes. Prikaz odnosa komponenti i populacija dat je u odvojenim biplotovima, oznake populacija odgovaraju tabeli 2.1.
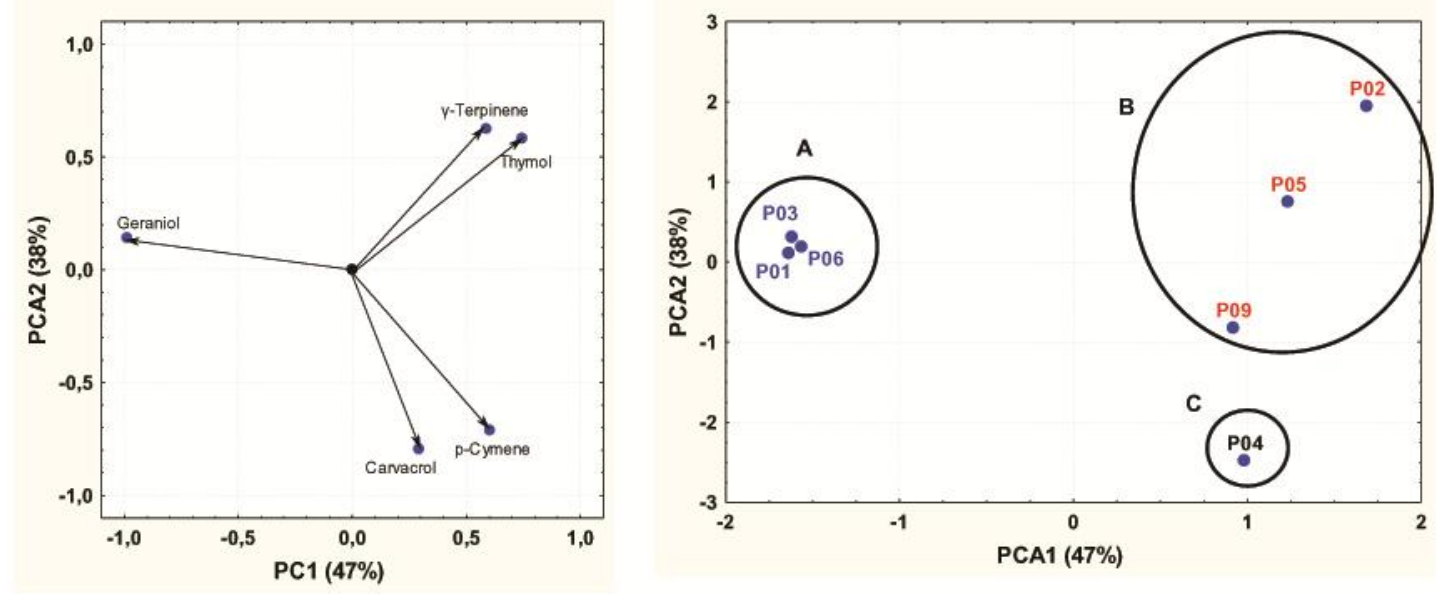

Tabela 3.7 Sopstvene vrednosti korelacione matrice i statistički podaci za komponente etarskog ulja podsekcije Alternantes

\begin{tabular}{|c|c|c|c|}
\hline & $\begin{array}{c}\text { Sopstvena } \\
\text { vrednost }\end{array}$ & $\begin{array}{c}\text { \% Totalna } \\
\text { varijansa }\end{array}$ & $\begin{array}{c}\text { Cumulative } \\
\%\end{array}$ \\
\hline 1 & 2.326429 & 46.52858 & 46.5286 \\
\hline 2 & 1.885059 & 37.70117 & 84.2297 \\
\hline
\end{tabular}

$\mathrm{Na}$ osnovu pet procentualno najzastupljenijih sastojaka etarskih ulja izračunata je Euklidska udaljenost između populacija (Tabela 3.8). Prosečna Euklidska udaljenost je bila 2,89, dok je raspon bio od 0,001, između populacija P01 i P06, do 4,51 između populacija P02 i P04. Slični rezultati su dobijeni i primenom klaster analize, grupisanje populacija u klastere je prikazano na UPGMA dendrogramu (Slika 3.1). 
Tabela 3.8 Matrica Euklidskih distanci između populacija podsekcije Alternantes na osnovu 15 najzastupljenijih sastojaka etarskog ulja.

\begin{tabular}{|l|l|l|l|l|l|l|l|}
\hline & P01 & P02 & P03 & P04 & P05 & P06 & P09 \\
\hline P01 & 0,00 & 3,83 & 0,02 & 3,83 & 3,10 & 0,00 & 3,07 \\
\hline P02 & 3,83 & 0,00 & 3,84 & 4,51 & 2,36 & 3,83 & 3,58 \\
\hline P03 & 0,02 & 3,84 & 0,00 & 3,84 & 3,11 & 0,02 & 3,09 \\
\hline P04 & 3,83 & 4,51 & 3,84 & 0,00 & 3,68 & 3,83 & 2,79 \\
\hline P05 & 3,10 & 2,36 & 3,11 & 3,68 & 0,00 & 3,10 & 2,14 \\
\hline P06 & 0,00 & 3,83 & 0,02 & 3,83 & 3,10 & 0,00 & 3,07 \\
\hline P09 & 3,07 & 3,58 & 3,09 & 2,79 & 2,14 & 3,07 & 0,00 \\
\hline
\end{tabular}

Slika 3.1 Dendrogram UPGMA na osnovu Euklidskih udaljenosti između populacija podsekcije Alternantes.

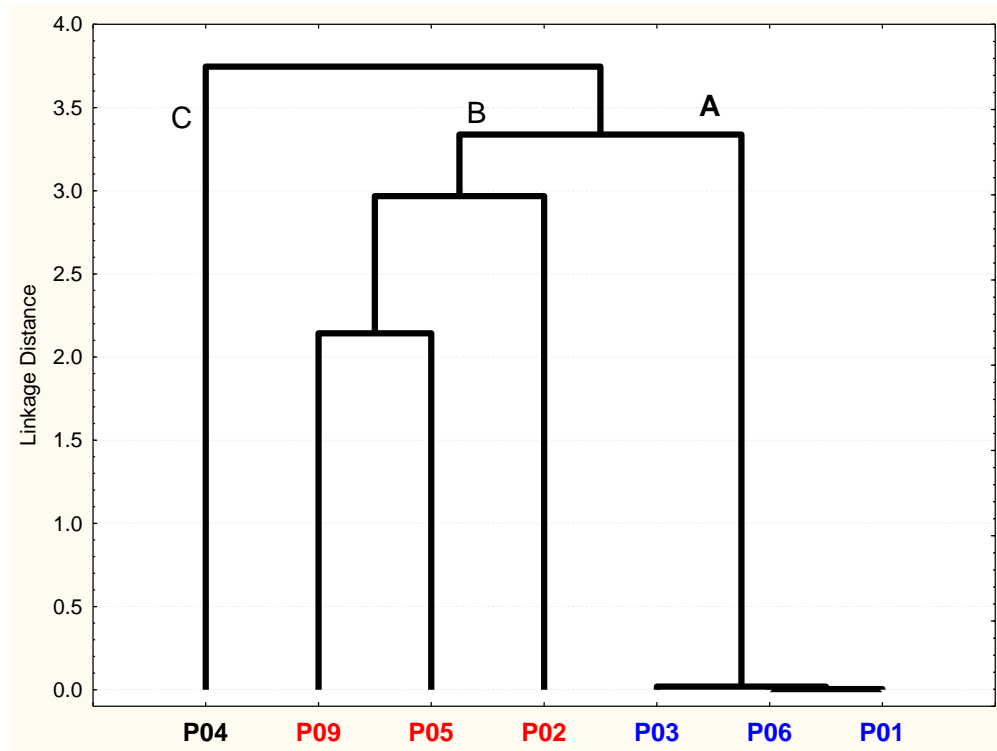

\section{Statistička obrada sastava etarskih ulja podsekcije Isolepides}

Pearsonov koeficijent korelacije za petnaest sastojaka etarskog ulja koji prelaze $10 \%$, dat je u tabeli 3.9. Visoka korelacija postoji u osam slučajeva pri pragu značajnosti $P<0,05$, odnosno u šest slučajeva pri pragu značajnosti $P<0,01$. Geranial je bio značajno $(\mathrm{r}=1,00 ; P<0,01)$ pozitivno korelisan sa neralom, $\alpha$-terpineol je bio značajno $(\mathrm{r}=1,00 ; P<0,01)$ pozitivno korelisan sa $\mathrm{E}-\gamma$-bisabolenom. $\alpha$-terpineol je bio značajno $(\mathrm{r}=0,94 ; P<0,01)$ pozitivno korelisan sa mircenom, E- $\gamma$-bisabolen je bio značajno $(\mathrm{r}=0,94 ; P<0,01)$ pozitivno korelisan sa mircenom, $(\mathrm{E})$-kariofilen je bio 
značajno $(\mathrm{r}=0,80 ; P<0,01)$ pozitivno korelisan sa limonenom i $(\mathrm{E})$ - $\beta$-ocimen je bio značajno $(\mathrm{r}=0,64 ; P<0,01)$ pozitivno korelisan sa $\alpha$-pinenom. $\gamma$-terpinen je bio značajno $(\mathrm{r}=0,57 ; P<0,05)$ pozitivno korelisan sa timolom, a limonen je bio značajno $(\mathrm{r}=0,59$; $P<0,05)$ pozitivno korelisan sa $(\mathrm{E})$ - $\beta$-ocimenom. Linalool, $p$-cimen, timol metil etar i germakren-D nisu bili u značajnoj korelaciji $(P>0,5)$ ni sa jednim glavnim sastojkom etarskog ulja. 
Tabela 3.9 Korelacije između pet najzastupljenijih komponenti etarskog ulja podsekcije Isolepides

\begin{tabular}{|c|c|c|c|c|c|c|c|c|}
\hline & $\alpha$-Pinene & Myrcene & p-Cymene & Limonene & (E)-B-Ocimene & $\gamma$-Terpinene & Linalool & \\
\hline$\alpha$-Pinene & 1.00 & ns & ns & ns & $* * *$ & ns & ns & \\
\hline Myrcene & 0.15 & 1.00 & ns & ns & $\mathrm{ns}$ & ns & ns & \\
\hline p-Cymene & -0.25 & -0.23 & 1.00 & ns & ns & ns & ns & \\
\hline Limonene & 0.25 & -0.03 & -0.20 & 1.00 & $*$ & ns & ns & \\
\hline (E)-B-Ocimene & 0.64 & 0.26 & -0.32 & 0.59 & 1.00 & ns & ns & \\
\hline G-Terpinene & -0.29 & -0.22 & 0.13 & -0.23 & -0.38 & 1.00 & ns & \\
\hline Linalool & -0.09 & -0.12 & -0.15 & -0.11 & -0.16 & -0.18 & 1.00 & \\
\hline$\alpha$-Terpineol & -0.08 & 0.94 & -0.14 & -0.08 & 0.02 & -0.16 & -0.06 & \\
\hline Thymol methyl ether & -0.21 & -0.21 & 0.48 & -0.18 & -0.31 & 0.47 & -0.15 & \\
\hline Neral & -0.15 & -0.12 & -0.13 & -0.11 & -0.16 & -0.16 & -0.07 & \\
\hline Geranial & -0.15 & -0.12 & -0.13 & -0.11 & -0.16 & -0.16 & -0.07 & \\
\hline Thymol & -0.34 & -0.24 & 0.02 & -0.26 & -0.42 & 0.57 & -0.20 & \\
\hline (E)-Caryophyllene & -0.13 & 0.13 & -0.24 & 0.80 & 0.27 & -0.29 & -0.08 & \\
\hline Germacrene-D & 0.47 & 0.06 & -0.30 & -0.11 & 0.22 & -0.35 & -0.13 & \\
\hline (E)- $\gamma$-Bisabolene & -0.08 & 0.94 & -0.14 & -0.08 & 0.02 & -0.16 & -0.07 & \\
\hline & $\alpha$-Terpineol & Thymol methyl ether & Neral & Geranial & Thymol & (E)-Caryophyllene & Germacrene-D & (E)- $\gamma$-Bisabolene \\
\hline$\alpha$-Pinene & ns & ns & ns & ns & ns & ns & ns & ns \\
\hline Myrcene & $* * *$ & ns & ns & ns & ns & ns & ns & $* * *$ \\
\hline p-Cymene & ns & ns & ns & ns & ns & ns & ns & ns \\
\hline Limonene & $\mathrm{ns}$ & ns & $\mathrm{ns}$ & ns & $\mathrm{ns}$ & $* * *$ & ns & ns \\
\hline (E)-B-Ocimene & $\mathrm{ns}$ & ns & $\mathrm{ns}$ & ns & $\mathrm{ns}$ & ns & $\mathrm{ns}$ & $\mathrm{ns}$ \\
\hline$\gamma$-Terpinene & ns & ns & ns & ns & $*$ & ns & ns & ns \\
\hline Linalool & ns & ns & ns & ns & ns & ns & ns & ns \\
\hline$\alpha$-Terpineol & 1.00 & ns & ns & ns & ns & ns & ns & $* * *$ \\
\hline Thymol methyl ether & -0.14 & 1.00 & ns & ns & ns & ns & ns & ns \\
\hline Neral & -0.07 & -0.14 & 1.00 & $* * *$ & ns & ns & ns & ns \\
\hline
\end{tabular}




\begin{tabular}{|c|c|c|c|c|c|c|c|c|}
\hline & $\alpha$-Terpineol & Thymol methyl ether & Neral & Geranial & Thymol & (E)-Caryophyllene & Germacrene-D & (E)- $\gamma$-Bisabolene \\
\hline Geranial & -0.07 & -0.14 & 1.00 & 1.00 & ns & ns & $\mathrm{ns}$ & ns \\
\hline Thymol & -0.18 & 0.14 & -0.18 & -0.18 & 1.00 & ns & $\mathrm{ns}$ & ns \\
\hline (E)-Caryophyllene & 0.16 & -0.24 & -0.14 & -0.14 & -0.30 & 1.00 & $\mathrm{~ns}$ & ns \\
\hline Germacrene-D & -0.06 & -0.29 & -0.14 & -0.14 & -0.39 & 0.02 & 1.00 & ns \\
\hline (E)- $\gamma$-Bisabolene & 1.00 & -0.14 & -0.07 & -0.07 & -0.18 & 0.17 & -0.06 & 1.00 \\
\hline
\end{tabular}

Tabela 3.9 Nastavak; ns - nema znacaj, $*(0.05<\mathrm{p}<0.01), * *(\mathrm{p}<0.01)$ 
PCA analiza glavnih komponenti pokazala je da šest komponenti ima sopstvene vrednosti (eigenvalues) veće od 1,00 i da su zajedno objašnjavale 85,97\% ukupne varijanse (Tabela 3.10). Na grafiku 3.2 prikazani su biploti na osnovu prve i druge ose, treće i četvrte i pete i šeste ose. PC1 razdvaja populacije bogate timolom, $\gamma$-terpinenom, timol metil etrom i $p$-cimenom od ostalih populacija, dok PC2 odvaja one bogate E- $\gamma$ bisabolenom, $\alpha$-terpineolom i mircenom od onih bogatih sa (E)-kariofilenom, germakrenom-D, $\alpha$-pinenom, (E)- $\beta$-ocimenom i limonennom. PC3 razdvaja populacije sa citralom (neral i geranial), dok PC4 odvja populacije sa $(E)$-kariofilenom. Populacije bogate linaloolom odvaja PC5, a PC6 razdvaja populacije sa visokim sadržajem pcimena i timol metil etra od onih koje sadrže visoke koncentracije $\gamma$-terpinena i timola. PCA nije pokazala da se populacija P19 izdvaja ni po jednoj komponenti.

Tabela 3.10 Sopstvene vrednosti korelacione matrice i statistički podaci za komponente etarskog ulja podsekcije Isolepides

\begin{tabular}{|r|c|r|r|}
\hline & $\begin{array}{c}\text { Sopstvena } \\
\text { vrednost }\end{array}$ & $\begin{array}{c}\text { \% Totalne } \\
\text { varijanse }\end{array}$ & $\begin{array}{c}\text { Kumulativni } \\
\%\end{array}$ \\
\hline 1 & 3,771647 & 25,14431 & 25,1443 \\
\hline 2 & 2,707895 & 18,05263 & 43,1969 \\
\hline 3 & 2,270200 & 15,13466 & 58,3316 \\
\hline 4 & 1,669963 & 11,13309 & 69,4647 \\
\hline 5 & 1,271889 & 8,47926 & 77,9440 \\
\hline 6 & 1,203106 & 8,02071 & 85,9647 \\
\hline
\end{tabular}

$\mathrm{Na}$ osnovu petnaest najzastupljenijih komponenti etarskih ulja izračunata je Euklidska udaljenost između populacija (Tabela 3.11). Prosečna Euklidska udaljenost među populacijama Th. glabrescens je bila 3,11, dok je raspon bio od 0,43, između populacija P10 i P14, do 5,18 između populacija P15 i P33. Prosečna Euklidska udaljenost među populacijama Th. marschallianus je bila 3,90, dok je raspon bio od 2,41, između populacija P16 i P17, do 3,29 između populacija P16 i P18. Prosečna Euklidska udaljenost među populacijama Th. pannonicus je bila 6,51, dok je raspon bio od 3,26, između populacija P19 i P20, do 9,05 između populacija P23 i P34. 
Grafik 3.2. Biplot dobijen Analizom glavnih komponenti na osnovu pet najzastupljenija jedinjenja etarskog ulja analizirane kod podsekcije Isolepides. Prikaz odnosa komponenti i populacija dat je u odvojenim biplotovima, oznake populacija odgovaraju tabeli 2.1.
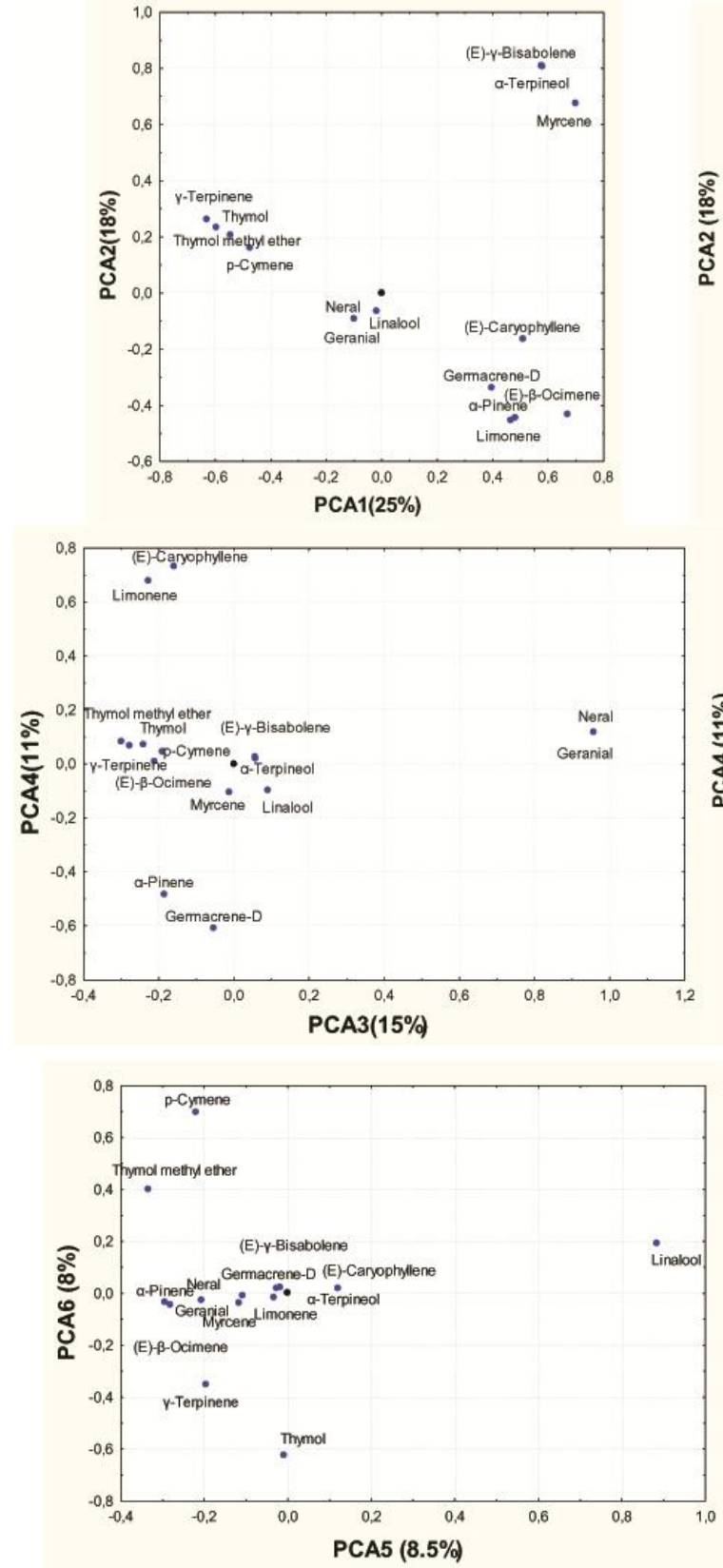
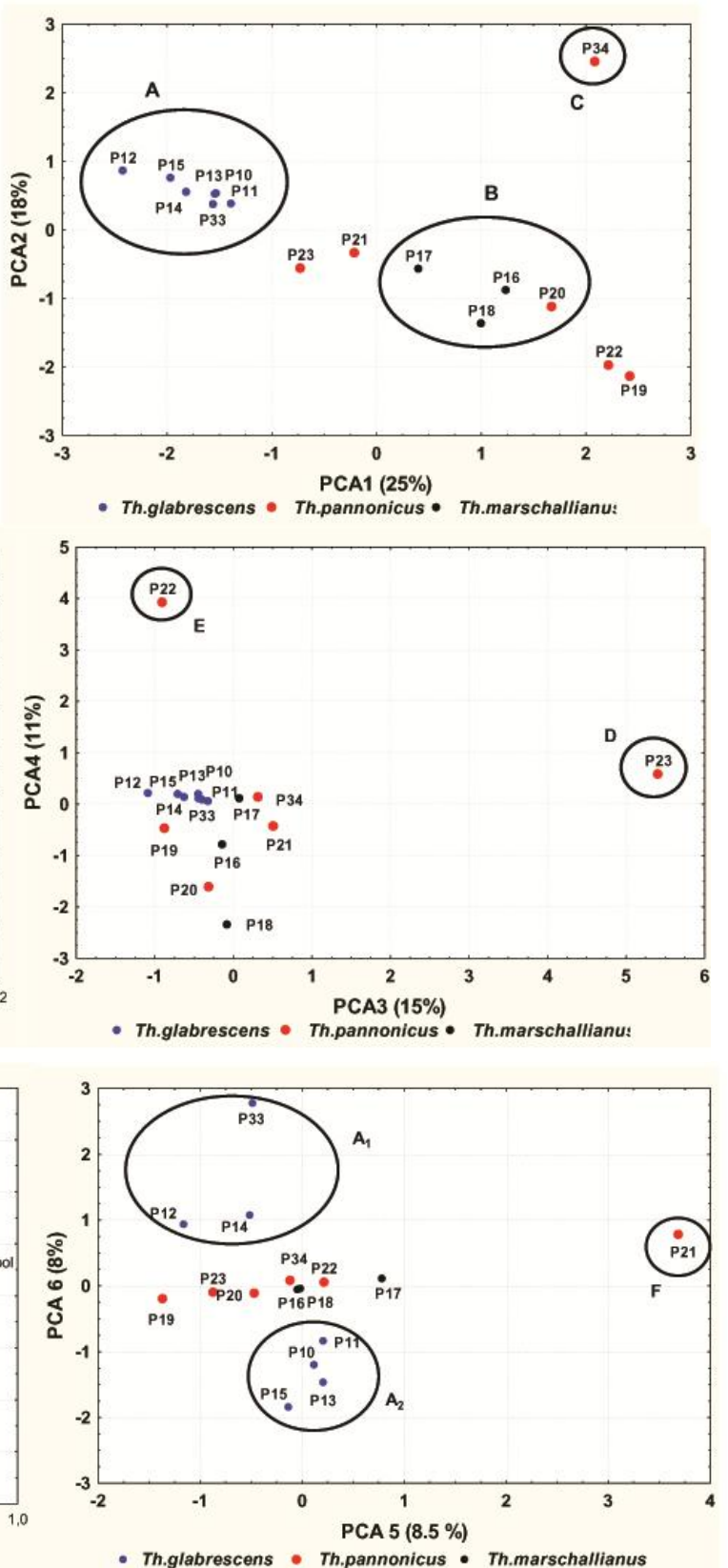
Tabela 3.11 Matrica Euklidskih distanci između populacija podsekcije Isolepides na osnovu 15 najzastupljenijih sastojaka etarskog ulja.

\begin{tabular}{|c|c|c|c|c|c|c|c|c|c|c|c|c|c|c|c|c|}
\hline & P10 & P11 & P12 & P13 & P33 & P14 & P15 & P16 & \begin{tabular}{|l} 
P17 \\
\end{tabular} & P18 & P19 & P20 & P21 & P22 & P23 & P34 \\
\hline P10 & 0,00 & 1,13 & 3,94 & 0,43 & 4,14 & 2,51 & 2,17 & 3,95 & 3,16 & 4,72 & 5,67 & 4,29 & 4,83 & 6,17 & 6,25 & 7,45 \\
\hline P11 & 1,13 & 0,00 & 4,17 & 1,03 & 4,00 & 2,79 & 3,29 & 3,95 & 3,14 & 4,69 & 5,65 & 4,29 & 4,80 & 6,17 & 6,24 & 7,50 \\
\hline P12 & 3,94 & 4,17 & 0,00 & 4,13 & 4,45 & 2,78 & 4,09 & 5,42 & 4,86 & 5,95 & 6,69 & 5,62 & 6,08 & \begin{tabular}{|l}
7,19 \\
\end{tabular} & 7,28 & 8,35 \\
\hline P13 & 0,43 & 1,03 & 4,13 & 0,00 & 4,45 & 2,87 & 2,38 & 4,09 & 3,29 & 4,85 & 5,81 & 4,45 & 4,94 & 6,20 & 6,34 & 7,53 \\
\hline P33 & 4,14 & 4,00 & 4,45 & 4,45 & 0,00 & 2,20 & 5,18 & 4,86 & 4,22 & 5,49 & 6,36 & 5,18 & 5,57 & 6,78 & 6,84 & 8,05 \\
\hline P14 & 2,51 & 2,79 & 2,78 & 2,87 & 2,20 & 0,00 & 3,19 & 4,19 & 3,42 & 4,88 & 5,80 & 4,49 & 4,99 & 6,30 & 6,39 & 7,63 \\
\hline P15 & 2,17 & 3,29 & 4,09 & 2,38 & 5,18 & 3,19 & 0,00 & 4,80 & 4,21 & 5,47 & 6,31 & 5,11 & 5,55 & 6,77 & 6,83 & 7,94 \\
\hline P16 & 3,95 & 3,95 & 5,42 & 4,09 & 4,86 & 4,19 & 4,80 & 0,00 & 2,41 & 3,29 & 4,09 & 2,43 & 4,92 & 5,40 & 6,39 & 6,93 \\
\hline P17 & 3,16 & 3,14 & 4,86 & 3,29 & 4,22 & 3,42 & 4,21 & 2,41 & 0,00 & 3,23 & 5,06 & 3,00 & 4,12 & 4,74 & 5,94 & 6,96 \\
\hline P18 & 4,72 & 4,69 & 5,95 & 4,85 & 5,49 & 4,88 & 5,47 & 3,29 & 3,23 & 0,00 & 5,13 & 2,28 & 5,54 & 6,58 & 6,89 & 7,80 \\
\hline P19 & 5,67 & 5,65 & 6,69 & 5,81 & 6,36 & 5,80 & 6,31 & 4,09 & 5,06 & 5,13 & 0,00 & 3,26 & 6,36 & 5,66 & 7,63 & 7,94 \\
\hline P20 & 4,29 & 4,29 & 5,62 & 4,45 & 5,18 & 4,49 & 5,11 & 2,43 & 3,00 & 2,28 & 3,26 & 0,00 & 5,17 & 5,78 & 6,65 & 6,92 \\
\hline P21 & 4,83 & 4,80 & 6,08 & 4,94 & 5,57 & 4,99 & 5,55 & 4,92 & 4,12 & 5,54 & 6,36 & 5,17 & 0,00 & 6,81 & 6,95 & 8,06 \\
\hline P22 & 6,17 & 6,17 & 7,19 & 6,20 & 6,78 & 6,30 & 6,77 & 5,40 & 4,74 & 6,58 & 5,66 & 5,78 & 6,81 & 0,00 & 7,99 & 8,32 \\
\hline P23 & 6,25 & 6,24 & 7,28 & 6,34 & 6,84 & 6,39 & 6,83 & 6,39 & \begin{tabular}{|l}
5,94 \\
\end{tabular} & 6,89 & 7,63 & 6,65 & 6,95 & \begin{tabular}{|l}
7,99 \\
\end{tabular} & 0,00 & 9,05 \\
\hline P34 & 7,45 & 7,50 & 8,35 & 7,53 & 8,05 & 7,63 & 7,94 & 6,93 & 6,96 & 7,80 & 7,94 & 6,92 & 8,06 & 8,32 & 9,05 & 0,00 \\
\hline
\end{tabular}


Grupisanje populacija u klastere je prikazano na UPGMA dendrogramu (Slika 3.2). Grupisanje populacija u klastere u saglasnosti je sa rezultatima PCA.

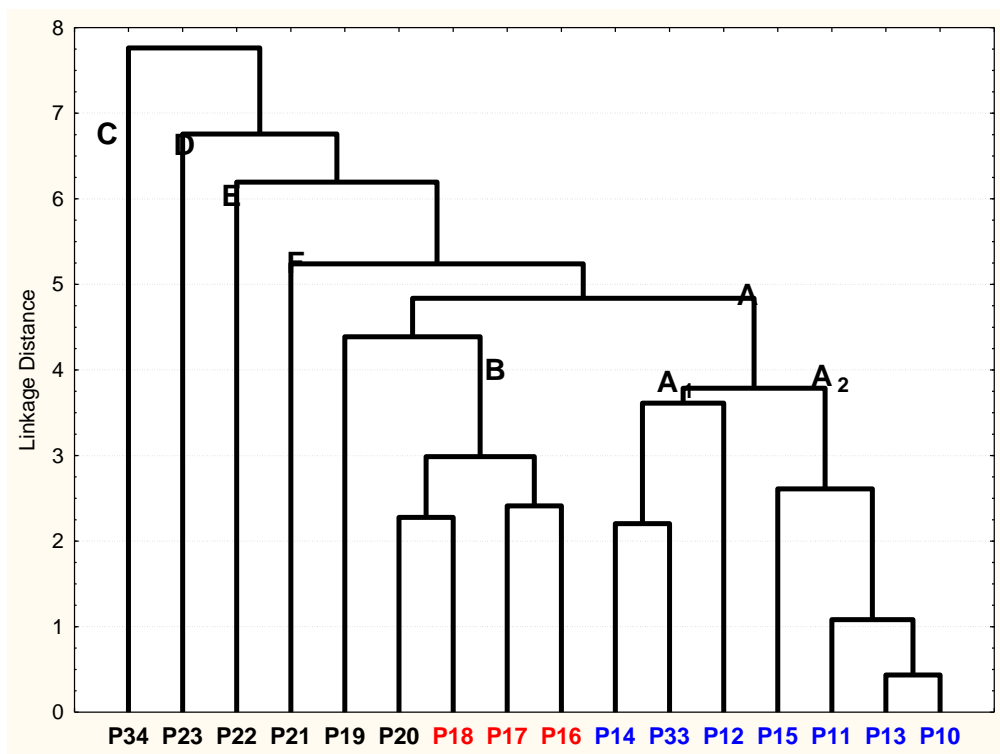

Slika 3.2 Dendrogram UPGMA na osnovu Euklidskih udaljenosti između populacija podsekcije Isolepides

\section{Statistička obrada sastava etarskih ulja podsekcije Pseudomarginati}

Pearsonov koeficijent korelacije za deset komponenti etarskog ulja koje prelaze $10 \%$, dat je u tabeli 3.12. Visoka korelacija postoji u četiri slučaja pri pragu značajnosti $P<0,05$, odnosno u tri slučaja pri pragu značajnosti $P<0,01$. Geranila je bio značajno $(\mathrm{r}=1,00 ; P<0,01)$ pozitivno korelisan sa neralom, neril acetat je bio značajno $(\mathrm{r}=0,97$; $P<0,01)$ pozitivno korelisan sa neralom i geranialom. (E)-kariofilen je bio značajno $(\mathrm{r}=0,90 ; P<0,05)$ pozitivno korelisan sa $\gamma$-kadinenom. Mircen, linalool, linalil acetat, $\alpha$ terpinil acetat i biciklogermakren nisu bili u značajnoj korelaciji $(P<0,5)$ ni sa jednom glavnom komponentom etarskih ulja. 
Tabela 3.12 Korelacije između pet najzastupljenijih komponenti etarskog ulja podsekcije Pseudomarginati

\begin{tabular}{|c|c|c|c|c|c|c|c|c|c|c|}
\hline & Myrcene & Linalool & Neral & $\begin{array}{l}\text { Linalyl } \\
\text { acetate }\end{array}$ & Geranial & $\begin{array}{l}\alpha- \\
\text { Terpinyl } \\
\text { acetate }\end{array}$ & $\begin{array}{l}\text { Neryl } \\
\text { acetate }\end{array}$ & $\begin{array}{l}\text { (E)- } \\
\text { Caryophyllene }\end{array}$ & Bicyclogermacrene & $\begin{array}{l}\text { G- } \\
\text { Cadinene }\end{array}$ \\
\hline Myrcene & 1.00 & ns & ns & ns & ns & ns & ns & ns & ns & $\mathrm{ns}$ \\
\hline Linalool & 0.68 & 1.00 & ns & ns & ns & ns & ns & ns & ns & $\mathrm{ns}$ \\
\hline Neral & -0.33 & -0.38 & 1.00 & ns & $* * *$ & ns & $* * *$ & ns & ns & $\mathrm{ns}$ \\
\hline Linalyl acetate & 0.60 & 0.60 & -0.40 & 1.00 & ns & ns & ns & ns & ns & $\mathrm{ns}$ \\
\hline Geranial & -0.34 & -0.38 & 1.00 & -0.40 & 1.00 & ns & $* * *$ & $\mathrm{~ns}$ & $\mathrm{~ns}$ & $\mathrm{~ns}$ \\
\hline$\alpha$-Terpinyl acetate & -0.35 & -0.38 & -0.20 & -0.40 & -0.20 & 1.00 & ns & $\mathrm{ns}$ & ns & $\mathrm{ns}$ \\
\hline Neryl acetate & -0.15 & -0.17 & 0.97 & -0.36 & 0.97 & -0.28 & 1.00 & ns & $\mathrm{ns}$ & $\mathrm{ns}$ \\
\hline (E)-Caryophyllene & -0.24 & -0.48 & -0.03 & -0.22 & -0.03 & -0.40 & -0.14 & 1.00 & $\mathrm{~ns}$ & * \\
\hline Bicyclogermacrene & -0.19 & 0.10 & 0.02 & 0.65 & 0.02 & -0.34 & -0.09 & 0.00 & 1.00 & $\mathrm{~ns}$ \\
\hline G-Cadinene & -0.49 & -0.42 & -0.05 & -0.44 & -0.05 & -0.25 & -0.15 & 0.90 & -0.06 & 1.00 \\
\hline
\end{tabular}

ns - nema znacaj, * $(0.05<\mathrm{p}<0.01), * *(\mathrm{p}<0.01)$ 
PCA analiza glavnih komponenti pokazala je da četiri komponente imaju svojstvene vrednosti (eigenvalues) veće od 1,00 i da su zajedno objašnjavale 95,72\% ukupne varijanse (Tabela 3.13). Na grafiku 3.3 prikazan je biplot na osnovu prve i druge ose i treće i četvrte ose. PC1 je odvajala populacije sa linalil acetatom i linaloolom, PC2 populacije sa citralom (neral i geranial). PC3 je odvajala populacije sa $\alpha$-terpinil acetatom, PC4 populacije sa biciklogermakrenom.

Grafik 3.3. Biplot dobijen Analizom glavnih komponenti na osnovu deset najzastupljenija jedinjenja etarskog ulja analizirane kod podsekcije Pseudomarginati. Prikaz odnosa komponenti i populacija dat je u odvojenim biplotovima, oznake populacija odgovaraju tabeli 2.1.
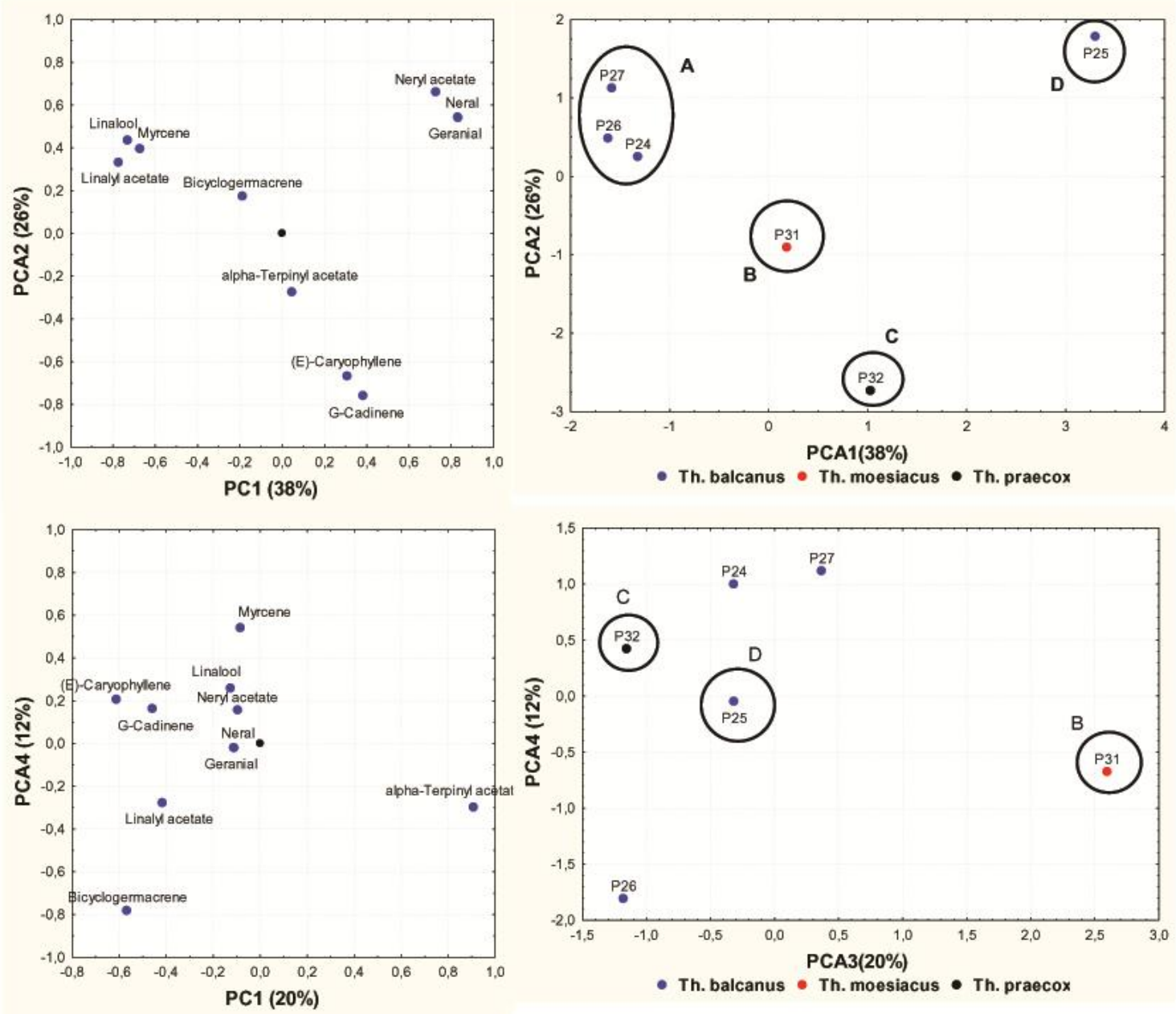
Tabela 3.13 Sopstvene vrednosti korelacione matrice i statistički podaci za komponente etarskog ulja podsekcije Pseudomarginati

\begin{tabular}{|r|c|c|r|}
\hline & $\begin{array}{c}\text { Sopstvena } \\
\text { vrednost }\end{array}$ & $\begin{array}{c}\% \\
\text { Totalne } \\
\text { varijanse }\end{array}$ & $\begin{array}{c}\text { Kumulativni } \\
\%\end{array}$ \\
\hline 1 & 3.774681 & 37.74681 & 37.7468 \\
\hline 2 & 2.605924 & 26.05924 & 63.8061 \\
\hline 3 & 1.960076 & 19.60076 & 83.4068 \\
\hline 4 & 1.231002 & 12.31002 & 95.7168 \\
\hline
\end{tabular}

$\mathrm{Na}$ osnovu deset najzastupljenijih komponenti etarskih ulja izračunata je Euklidska udaljenost između populacija (Tabela 3.14). Prosečna Euklidska udaljenost za populacije vrste je Th. balcanus je bila 4,12, dok je raspon bio od 2,32, između P24 i P27, do 5,46, među populacijama P25 i P26. Kod vrsta Th. moesiacus i Th. praecox uzorkovana je samo jedna populacija, tako da se Euklidske udaljenosti ne mogu računati.

Tabela 3.14 Matrica Euklidskih distanci između populacija podsekcije Isolepides na osnovu 15 najzastupljenijih sastojaka etarskog ulja.

\begin{tabular}{|l|l|l|l|l|l|l|}
\hline & P24 & P25 & P26 & P27 & P31 & P32 \\
\hline P24 & 0,00 & 5,09 & 3,18 & 2,32 & 3,98 & 4,17 \\
\hline P25 & 5,09 & 0,00 & 5,46 & 5,20 & 5,08 & 5,16 \\
\hline P26 & 3,18 & 5,46 & 0,00 & 3,48 & 4,56 & 4,74 \\
\hline P27 & 2,32 & 5,20 & 3,48 & 0,00 & 4,06 & 4,99 \\
\hline P31 & 3,98 & 5,08 & 4,56 & 4,06 & 0,00 & 4,41 \\
\hline P32 & 4,17 & 5,16 & 4,74 & 4,99 & 4,41 & 0,00 \\
\hline
\end{tabular}

Grupisanje populacija u klastere je prikazano na UPGMA dendrogramu (Slika 3.3), i pokazalo je da grupisanje populacija u klastere odgovara onom u PCA. 


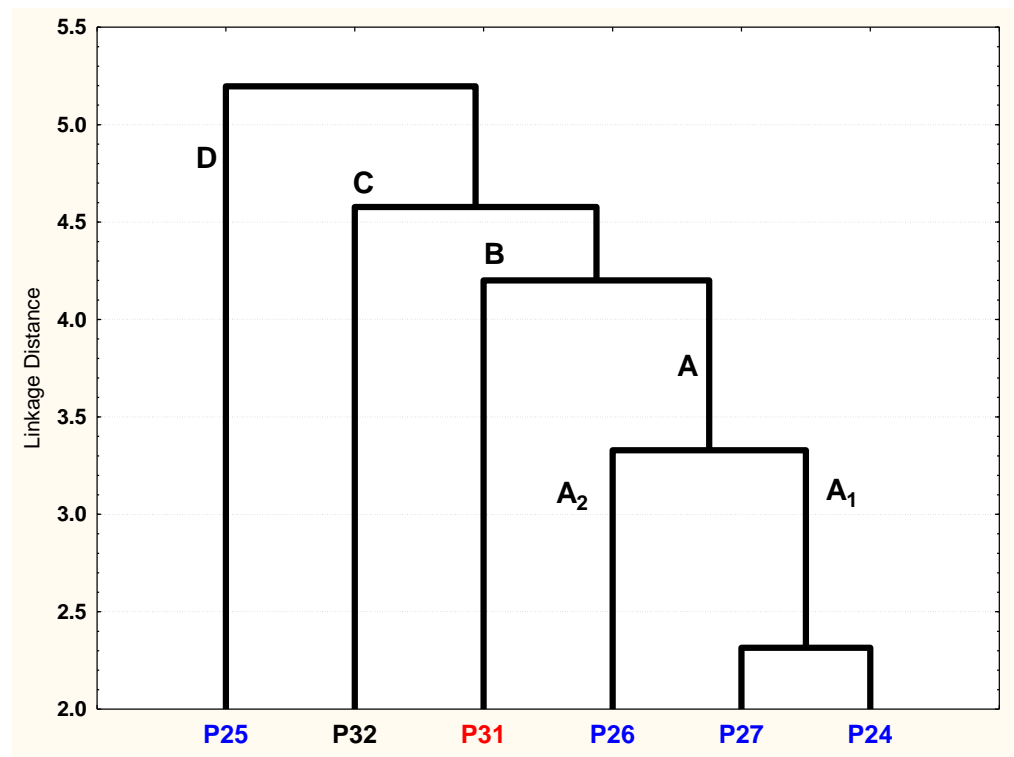

Slika 3.3. Dendrogram UPGMA na osnovu Euklidskih udaljenosti između populacija podsekcije Pseudomarginati

\subsubsection{Površinski flavonoidi}

Identifikovani površinski flavonoidi, njihova LC-MS retenciona vremena, UV spektar i maseni APCI spektar su poređeni sa onima kod vrsta roda Thymus iz Makedonije (Marin i sar., 2003) i dati u Tabeli 3.15. U tabeli 3.15 flavoni su grupisani u šest grupa, prema modelu substitucija u A prstenu. Ovi modeli suspstitucija često su od značaja za taksonomska ispitivanja (Tomás-Barberán i Gill, 1992; Grayer i sar., 2001).

Distribucija površinskih flavona $\mathrm{i}$ flavanona $\mathrm{u}$ ispitivanim populacijama vrsta roda Thymus je data u Tabeli 3.16. Ova tabela jedata u skladu sa tabelom koju je dao Hernández i sar. (1987), koji je proučavao vrste roda Thymus sa Pirinejskog poluostrva, i prikazuje najzastupljenije, drugo po zastupljenosti, kao i ostala prisutna jedinjenja. Apsolutna količina najzastupljenijeg flavona je prikazana u posebnoj koloni. Tri ispitavne populacije vrste Th. balcanus su produkovale površinske flavonoide samo u tragovima, dok se kod svih ostalih uzoraka produkcija ovih jedinjenja kretala između niske i srednje. Unekim uzorcima je takođe utvrđeno i prisustvo flavanona, koje je u pojedinim slučajevima bilo veoma visoko. Prisustvo eriodiktiola je utvrđeno u jednoj populaciji vrste Th. marschallianus. Osim ovog flavanona utvrđeno je i prisustvo još tri 
metoksilovana flavanona, dihidroksi-tetrametoksiflavonon $\left(R_{\mathrm{t}}=15,2 \mathrm{~min} ; \mathrm{MH}^{+}=347\right), 5$ hidroksi-6, 7, 4'-trimetoksi flavanon $\left(R_{\mathrm{t}}=17,2 \mathrm{~min} ; \mathrm{Mh}^{+}=331\right)$ i 5- hidroksi -6, 7, 8, 4'tetrametoksi flavanoe $\left(R_{\mathrm{t}}=1742 \mathrm{~min} ; \mathrm{MH}=361\right)$. Svi ovi flavanoni su bili prisutni kod vrsta iz podsekcije Isolepides, sa izuzetkom Th. praecox kod koga je ustanovljeno veoma visoko prisustvo 5- hidroksi -6, 7, 8, 4'-tetrametoksi flavanoe. 
Tabela 3.15 LC-MS retenciona vremena, HPLC UV absorpcioni maksimumi i podaci APCI-masenog spektra za površinske flavonoide kod vrsta roda Thymus.

Komp.

Tip supstitucije u A prstenu i naziv flavona

5,7-diOH and 5,6,7-triOH flavoni

$1 \quad 5,7,3^{\prime}, 4^{\prime}$-tetraOH flavone (luteolin)

5-OH-7-OMe flavon

3 5,4'-OH-7-OMe (genkwanin)

5,6-diOH-7-OMe flavoni

$4 \quad 5,6,4^{\prime}$-triOH-7, $3^{\prime}$-diOMe

or $5,6,3^{\prime}$-triOH-7, $4^{\prime}$-diOMe

$5 \quad 5,6,-$ diOH-7, $3^{\prime}, 4^{\prime}$-triOMe

$6 \quad 5,6$-diOH-7,4'-diOMe (ladanein)

5,6-diOH-7,8-diOMe flavoni

$7 \quad 5,6,4^{\prime}$-triOH-7,8-diOMe (thymusin)

$85,6,4^{\prime}$-triOH-7,8,3'-triOMe (thymonin)

$9 \quad 5,6$-diOH-7,8, $3^{\prime} 4^{\prime}$-tetraOMe

10 5,6-diOH-7,8,4'-triOMe (pebrellin)

5-OH-6,7-diOMe flavoni

$115,4^{\prime}$-diOH-6,7-diOMe (cirsimaritin)

12 5-OH-6,7,4'-triOMe (salvigenin)

5-OH-6,7,8-triOMe flavoni

$13 \quad 5,4^{\prime}$-diOH-6,7,8-triOMe (xanthomicrol)

14 5-OH-6,7,8,3',4'-pentaOMe (5-desmethylnobiletin)

15 5-OH-6,7,8, $4^{\prime}$-tetraOMe (gardenin B)
$R_{\mathrm{t}}(\min ) \quad \mathrm{UV} \lambda_{\max } \quad \mathrm{MH}^{+}$

$(\mathbf{L C}-\mathrm{MS}) \quad(\mathrm{nm}) \quad(\mathrm{m} / \mathrm{z})$

$\begin{array}{lll}13.6 & 255,347 & 287 \\ 14.9 & 268,340 & 271 \\ 17.4 & 268,336 & 285 \\ & & \\ 13.7 & 284,336 & 331 \\ & & \\ 15.0 & 284,344 & 345 \\ 16.1 & 288,332 & 315\end{array}$

$\begin{array}{ll}14.6 & 296,336 \\ 14.6 & 331\end{array}$

$14.6 \quad 288,348 \quad 361$

$15.9 \quad 288,344 \quad 375$

$\begin{array}{lll}17.0 & 296,332 & 345\end{array}$

$\begin{array}{lll}15.9 & 275,336 & 315\end{array}$

$\begin{array}{ll}17.8 & 276,332 \\ \end{array}$

$\begin{array}{lll}16.8 & 280,332 & 345\end{array}$

$\begin{array}{lll}17.8 & 282,336 & 389\end{array}$

$18.7 \quad 284,332 \quad 359$


Tabela 3.16 Distribucija površinskih flavona i flavanona kod analiziranih vrsta roda Thymus iz Srbije.

\begin{tabular}{|c|c|c|c|c|c|c|c|c|c|c|c|c|c|c|c|c|c|}
\hline \multirow{3}{*}{ Takson } & \multirow{3}{*}{ Conc $^{\mathrm{a}}$} & \multicolumn{15}{|c|}{ Površinski flavoni } & \multirow{3}{*}{$\begin{array}{l}\text { Površinski } \\
\text { flavanoni }^{\mathrm{b}} \\
\end{array}$} \\
\hline & & \multirow{2}{*}{\begin{tabular}{|c|} 
Lute \\
$\mathbf{1}$ \\
\end{tabular}} & \multirow{2}{*}{\begin{tabular}{|c|} 
Apig \\
2 \\
\end{tabular}} & \multirow{2}{*}{\begin{tabular}{|c|} 
Genk \\
3 \\
\end{tabular}} & \multicolumn{3}{|c|}{$\begin{array}{c}\text { 5,6-diOH-7- } \\
\text { OMe }\end{array}$} & \multicolumn{4}{|c|}{$\begin{array}{c}\text { 5,6-diOH-7,8- } \\
\text { diOMe }\end{array}$} & \multicolumn{2}{|c|}{$\begin{array}{c}\text { 5-OH-6,7- } \\
\text { diOMe }\end{array}$} & \multicolumn{3}{|c|}{$\begin{array}{c}\text { 5-OH-6,7,8- } \\
\text { triOMe }\end{array}$} & \\
\hline & & & & & 4 & 5 & 6 & 7 & 8 & 9 & 10 & 11 & 12 & 13 & 14 & 15 & \\
\hline \multicolumn{18}{|c|}{ Subsect. Alternantes } \\
\hline \begin{tabular}{|l} 
Th. pulegioides \\
$\mathrm{P} 01$
\end{tabular} & 1 & +++ & & & & ++ & & & & ++ & & & & & & & \\
\hline $\begin{array}{l}\text { Th. pulegioides } \\
\text { P02 }\end{array}$ & $\mathrm{m}$ & & & & + & ++++ & |t & & & ++ & & & & $+?$ & & & \\
\hline $\begin{array}{l}\text { Th. pulegioides } \\
\text { P03 }\end{array}$ & $\mathrm{m}$ & |++ & + & & & +++ & + & & & ++ & & & & $+?$ & & & \\
\hline $\begin{array}{l}\text { Th. pulegioides } \\
\text { P04 }\end{array}$ & 1 & ++ & & & & +++ & & & & ++ & + & & & & & & \\
\hline \begin{tabular}{|l|} 
Th. pulegioides \\
P03 \\
\end{tabular} & $\mathrm{m}$ & ++ & + & & & +++ & + & & & ++ & & & & $+?$ & & & \\
\hline $\begin{array}{l}\begin{array}{l}\text { Th. pulegioides } \\
\text { P05 }\end{array} \\
\end{array}$ & 1 & & & $\mid+$ & + & +++ & |+ & & & ++ & & & & & & & \\
\hline \begin{tabular}{|l} 
Th. pulegioides \\
P06
\end{tabular} & 1 & + & & & & ++ & + & & ++ & +++ & & & & & & & \\
\hline \begin{tabular}{|l} 
Th. pulegioides \\
P09
\end{tabular} & $\mathrm{m}$ & & & & + & +++ & + & & & ++ & & & & + & & & \\
\hline \multicolumn{18}{|c|}{ Subsect. Isolepides } \\
\hline $\begin{array}{l}\text { Th. glabrescens } \\
\text { P10 }\end{array}$ & $\mathrm{m}$ & & & $\mid+$ & + & |+++ & |f+ & & + & ++ & |+ & & & & & & \\
\hline $\begin{array}{l}\text { Th. glabrescens } \\
\text { P11 }\end{array}$ & 1 & & & $\mid+$ & + & ||++ & ||$+$ & & + & ++ & $\mid++$ & & & & & & \\
\hline
\end{tabular}




\begin{tabular}{|c|c|c|c|c|c|c|c|c|c|c|c|c|c|c|c|c|c|}
\hline \multirow{3}{*}{ Takson } & \multirow{3}{*}{ Conc $^{\mathrm{a}}$} & \multicolumn{15}{|c|}{ Površinski flavoni } & \multirow{3}{*}{$\begin{array}{l}\text { Površinski } \\
\text { flavanoni }^{-} \\
\end{array}$} \\
\hline & & \multirow{2}{*}{\begin{tabular}{||c|} 
Lute \\
$\mathbf{1}$ \\
\end{tabular}} & \multirow{2}{*}{\begin{tabular}{|c|} 
Apig \\
2 \\
\end{tabular}} & \multirow{2}{*}{\begin{tabular}{||c|} 
Genk \\
3 \\
\end{tabular}} & \multicolumn{3}{|c|}{$\begin{array}{c}\text { 5,6-diOH-7- } \\
\text { OMe }\end{array}$} & \multicolumn{4}{|c|}{$\begin{array}{c}\text { 5,6-diOH-7,8- } \\
\text { diOMe }\end{array}$} & \multicolumn{2}{|c|}{$\begin{array}{c}\text { 5-OH-6,7- } \\
\text { diOMe }\end{array}$} & \multicolumn{3}{|c|}{$\begin{array}{c}\text { 5-OH-6,7,8- } \\
\text { triOMe }\end{array}$} & \\
\hline & & & & & 4 & $\overline{5}$ & $\overline{76}$ & 7 & 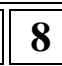 & 9 & 10 & 11 & 12 & 13 & 14 & 15 & \\
\hline $\begin{array}{l}\text { Th. glabrescens } \\
\text { P12 }\end{array}$ & 1 & & & $1+$ & & ++ & |++ & & & + & |+++ & & & & & & \\
\hline $\begin{array}{l}\text { Th. glabrescens } \\
\text { P13 }\end{array}$ & $\mathrm{m}$ & & & & + & |++ & |++ & & & ++ & + & & & & & & \\
\hline $\begin{array}{l}\text { Th. glabrescens } \\
\text { P14 }\end{array}$ & 1 & & & & & |++ & $\mid++$ & & & + & + & & & & & & \\
\hline $\begin{array}{l}\text { Th. glabrescens } \\
\text { P15 }\end{array}$ & 1 & + & & & & +++ & $\mid++$ & & + & ++ & + & & & & & & \\
\hline $\begin{array}{l}\text { Th. glabrescens } \\
\text { P33 }\end{array}$ & 1 & + & & & & +++ & ++ & & & ++ & + & & & & & & \\
\hline $\begin{array}{l}\text { Th. } \\
\text { marschallianus } \\
\text { P16 }\end{array}$ & 1 & & & & & & & & & & + & & ++ & & & $\mid+++$ & \\
\hline \begin{tabular}{|l} 
Th. \\
marschallianus \\
P17
\end{tabular} & 1 & & & & & & & & & & & & +++ & + & & ++ & \\
\hline \begin{tabular}{|l} 
Th. \\
marschallianus \\
P18
\end{tabular} & $\| 1$ & & & & & & & & & & & + & +++ & + & & ++ & E, M \\
\hline $\begin{array}{l}\text { Th. pannonicus } \\
\text { P19 }\end{array}$ & 1 & & + & & & & & & & & + & & +++ & & & ++ & $\mathrm{M}$ \\
\hline $\begin{array}{l}\text { Th. pannonicus } \\
\mathrm{P} 20\end{array}$ & $\| 1$ & & + & & & & & & & & & & +++ & & & ++ & $\mathrm{M}$ \\
\hline $\begin{array}{l}\text { Th. pannonicus } \\
\text { P21 }\end{array}$ & 1 & & & & & & & & & & + & & & & + & & $\mathrm{M}$ \\
\hline Th. pannonicus & 1 & & + & & & & & & & & & & & + & & + & $\mathrm{M}$ \\
\hline
\end{tabular}




\begin{tabular}{|c|c|c|c|c|c|c|c|c|c|c|c|c|c|c|c|c|c|}
\hline \multirow{3}{*}{ Takson } & \multirow{3}{*}{ Conc $^{-\mathbf{a}}$} & \multicolumn{15}{|c|}{ Površinski flavoni } & \multirow{3}{*}{$\begin{array}{l}\text { Površinski } \\
\text { flavanoni } \\
\end{array}$} \\
\hline & & \multirow{2}{*}{\begin{tabular}{|c|} 
Lute \\
1 \\
\end{tabular}} & \multirow{2}{*}{\begin{tabular}{|c|} 
Apig \\
2 \\
\end{tabular}} & \multirow{2}{*}{\begin{tabular}{|c|} 
Genk \\
3 \\
\end{tabular}} & \multicolumn{3}{|c|}{$\begin{array}{c}\text { 5,6-diOH-7- } \\
\text { OMe }\end{array}$} & \multicolumn{4}{|c|}{$\begin{array}{c}\text { 5,6-diOH-7,8- } \\
\text { diOMe }\end{array}$} & \multicolumn{2}{|c|}{$\begin{array}{l}\text { 5-OH-6,7- } \\
\text { diOMe }\end{array}$} & \multicolumn{3}{|c|}{$\begin{array}{c}\text { 5-OH-6,7,8- } \\
\text { triOMe }\end{array}$} & \\
\hline & & & & & 4 & 5 & 6 & 7 & 8 & 9 & 10 & 11 & 12 & 13 & 14 & 15 & \\
\hline \multicolumn{18}{|l|}{$\mathrm{P} 22$} \\
\hline & & & & & & & & & & & & & & & & & \\
\hline $\begin{array}{l}\text { Th. pannonicus } \\
\text { P23 }\end{array}$ & $\mathrm{m}$ & & & $\|+$ & ++ & ++ & & +++ & & & + & & & & & & \\
\hline $\begin{array}{l}\text { Th. pannonicus } \\
\text { P34 }\end{array}$ & 1 & & & & & & & & & & ++ & & & & & +++ & \\
\hline \multicolumn{18}{|c|}{ Subsect. Pseudomarginati } \\
\hline Th. balcanus P24 & $\operatorname{tr}$ & & & & & & & & & +++ & +++ & & & & & & \\
\hline Th. balcanus P25 & $\operatorname{tr}$ & & & & & & & & & ++ & +++ & & & & & & \\
\hline Th. balcanus P26 & 1 & & & + & & & & & & ++ & +++ & & & & & & \\
\hline Th. balcanus P27 & $\operatorname{tr}$ & & & & & & & & & +++ & +++ & & & & & & \\
\hline $\begin{array}{l}\text { Th. moesiacus } \\
\text { P31 }\end{array}$ & 1 & |++ & & $\mid+$ & & & & & & + & + & & & & & & \\
\hline $\begin{array}{l}\text { Th. praecox } \\
\text { P32 }\end{array}$ & 1 & & & & & & & & & & & & ++ & & & + & $M$ \\
\hline
\end{tabular}

+++ Flavoni sa najvećom UV absorpcijom na $335 \mathrm{~nm}$ u HPLC očitavanju ekstrakta; ++ Flavoni sa drugom po veličini UV absorpcijom na 335 nm u HPLC očitavanju ekstrakta; +minorni flavon u ekstraktu; Videti tabelu 3.10 za imena površinskih flavona 1-15. ${ }^{a}$ Conc, koncentracija flavonoida; h, visoka (UV absorpcija najvišeg HPLC pika u ekstraktu je >1.0 Absorpcione Jedinice AU); m, srednja (UV absorpcija najvišeg pika u ekstraktu je 0.1-1.0 AU); l, niska (UV absorpcija najvišeg pika u ekstraktu je 0.01-0.1 AU); tr, u tragovima (UV absorpcija najvišeg pika u ekstraktu je $<0.01 \mathrm{AU}$ ). ${ }^{\mathrm{b}}$ Flavanoni: E, eriodictyol; $\mathrm{M}$, metoksilovani flavanoni (nekoliko različitih jedinjenja, $\mathrm{MH}^{+} \mathrm{m} / \mathrm{z} 331,347$ i 361$)$. 


\subsection{AFLP markeri}

Osam kombinacija prajmera dalo je ukupno 2591 polimorfni marker u setu od 83 ispitaivana uzorka Thymus-a. Najveći i najmanji udeo polimorfnih traka kao i Šenonov informacioni indeks je utvrđen kod Th. pulegioides, odnosno Th. praecox (Tabela 3.17). Particija Šenonovog indeksa je pokazala da je totalni diverzitet $\left(\mathrm{H}_{\mathrm{t}}\right)$ bio 0,488, dok je prosečni diverzitet unutar vrsta $\left(\mathrm{H}_{\mathrm{sp}}\right)$ bio 0,355. Proporcija diverziteta unutar vrsta $(72.61 \%)$ je bila znatno viša nego proporcija diverziteta među vrstama $(27.39 \%)$.

Table 3.17 Molekularni diverzitet dobijen od 2591 AFLP markera kod kod sedam vrsta roda Thymus

\begin{tabular}{lcccc}
\hline Vrsta $($ Podsekcija*) & $\mathrm{n}$ & $\% \mathrm{P}$ & $\mathrm{N}_{\mathrm{pr}}$ & $\mathrm{H}_{\mathrm{j}}($ stdev $)$ \\
\hline Th. pulegioides $(\mathrm{A})$ & 25 & 73.41 & 80 & $0.406(0.332)$ \\
Th. glabrescens $(\mathrm{I})$ & 16 & 64.61 & 32 & $0.392(0.346)$ \\
Th. marschallianus $(\mathrm{I})$ & 8 & 51.18 & 2 & $0.366(0.380)$ \\
Th. pannonicus $(\mathrm{I})$ & 11 & 58.78 & 10 & $0.392(0.366)$ \\
Th. balcanus $(\mathrm{P})$ & 14 & 64.76 & 26 & $0.403(0.350)$ \\
Th. moesiacus $(\mathrm{P})$ & 6 & 40.06 & 7 & $0.314(0.395)$ \\
Th. praecox $(\mathrm{P})$ & 3 & 22.69 & 7 & $0.208(0.385)$ \\
\hline Average & 11.86 & 53.64 & 23.43 & $0.355(0.072)$ \\
Total & 83 & 100 & 164 & $0.488(0.248)$ \\
\hline
\end{tabular}

$\mathrm{n}$ - veličina uzorka; \% $\mathrm{P}$ - proporcija polimorfnih traka; $\mathrm{N}_{\mathrm{pr}}-$ broj osobenih traka; $\mathrm{H}_{\mathrm{j}}(\mathrm{stdev})$ - Shannonov informacioni indeks i njegova standardna devijacija

*Podsekcija: (A) Alternantes, (I) Isolepides, (P) Pseudomarginati

Nei i Lijeve distance zasnovane na AFLP podacima su se kretale od 0,43 do 0,76 , sa prosečnom vrednošću od 0,62 .

Tabela 3.18 Jednosmerna analiza molekularne varijanse (AMOVA) za prticiju AFLP variacije između sedam vrsta roda Thymus, među populacijama unutar vrste i unutar populacija

\begin{tabular}{cccccc}
\hline Izvor varijacije & df & $\begin{array}{c}\text { Komponenta } \\
\text { varijacije }\end{array}$ & Procenat varijacije & $\phi$-statistics & $\mathrm{P}(\phi)$ \\
\hline Among species & 6 & 0.033 & 10.45 & $\phi_{\mathrm{CT}}=0.104$ & $<0.0001$ \\
$\begin{array}{c}\text { Among populations } \\
\text { within species }\end{array}$ & 25 & 0.032 & 10.18 & $\phi_{\mathrm{SC}}=0.114$ & $<0.0001$ \\
Within populations & 51 & 0.253 & 79.38 & $\phi_{\mathrm{ST}}=0.206$ & $<0.0001$ \\
\hline
\end{tabular}

$\mathrm{P}(\phi)$ - $\phi$-statistics probability level after 10,000 permutations 


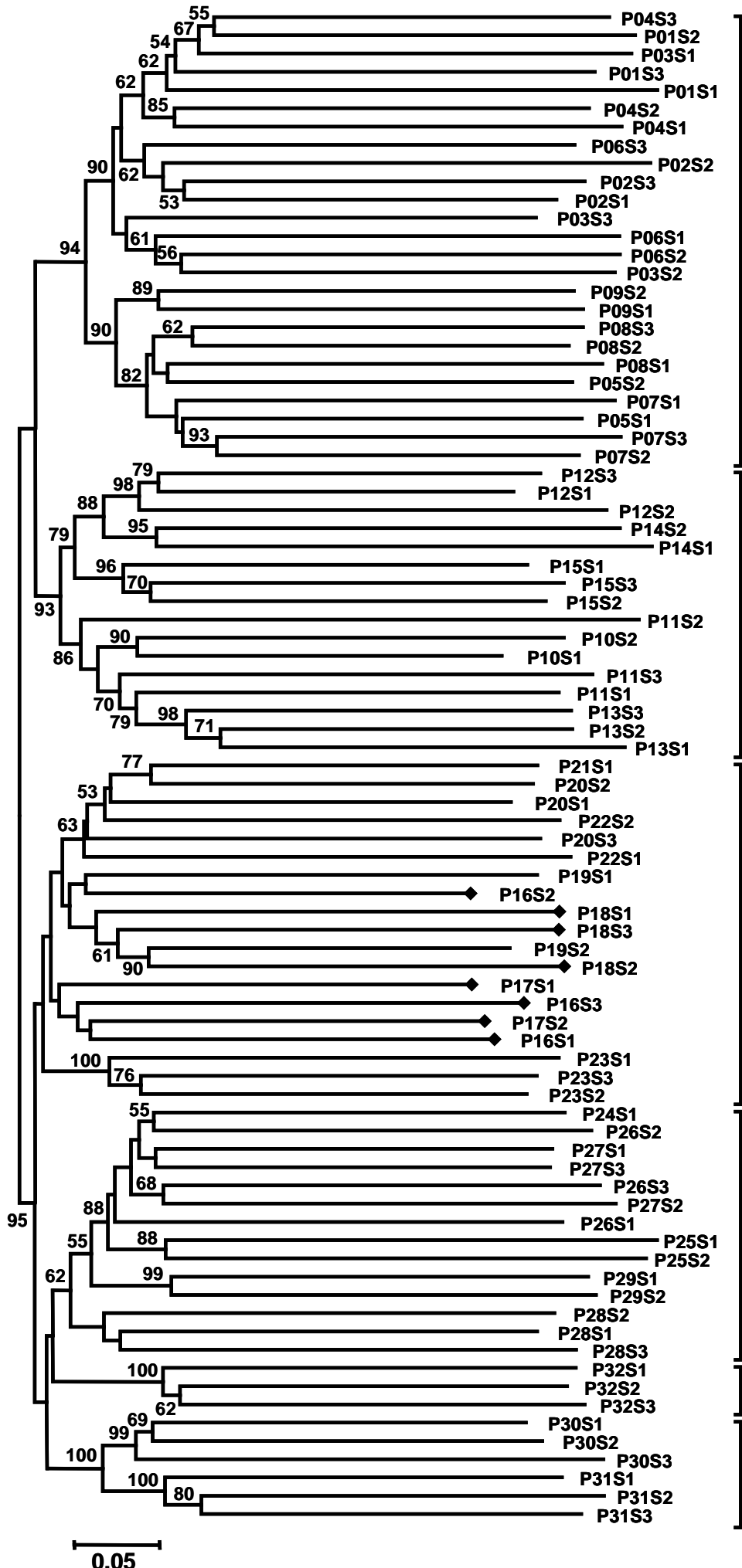

Th. pulegioides
Alternantes

Th. glabrescens Isolepides

Th. pannonicus Isolepides

$\rightarrow$ Th. marschallianus Isolepides

Th. balcanus

Pseudomarginati

Th. praecox

Pseudomarginati

Th. moesiacus

Pseudomarginati

Slika. 3.4 Neighbor-joining stablo zasnovano na Nei i Lijevom distancionom matriksu izvedenom iz AFLP podataka za sedam vrsta roda Thymus. Boostrap podrška vrednosti (BS; u procentima) 
Dvosmerna Analiza molekularne varijanse (AMOVA) je pokazala da najviše genetičkog diverziteta proizilazi iz razlike među jedinkama unutar populacija $(79.38 \%)$ (Tabela 3.18). Preostala varijabilnost bila je skoro podjednako distribuirana između vrsta (10.18\%) i između populacija unutar vrsta (10.45\%). Ipak, oba izvora varijabilnosti su imala veoma visoku značajnost $(\mathrm{P}<0.0001)$.

Serija jednosmernih AMOVA za svaku vrstu pokazala je da se komponenta varijabilnosti unutar vrste kretala od $85,5 \%$ kod Th. glabrescens do 92,3\% kod Th. marschallianus, ukazujući da sve analizirane vrste imaju sličnu distribuciju međupopulacijske i unutarpopulacijske varijabilnosti (Tabela 3.19). U svim slučajevima $\phi_{\mathrm{ST}}$-vrednosti su imale visoku značajnost, potvrđujući postojanje populacione strukture.

Tabela 3.19 Jednosmerna analiza molekularne varijanse (AMOVA) za particiju AFLP variacije između i unutar svake populacione komponente za svaku vrstu roda Thymus

\begin{tabular}{|c|c|c|c|c|}
\hline \multirow{2}{*}{ Vrsta (Podsekcia*) } & \multicolumn{2}{|c|}{ Procenat varijacije } & \multirow{2}{*}{$\phi$-statistics } & \multirow{2}{*}{$\mathrm{P}(\phi)$} \\
\hline & Među populacijama & Unutar populacija & & \\
\hline Th. pulegioides (A) & 11.15 & 88.85 & 0.112 & $<0.0001$ \\
\hline Th. glabrescens (I) & 14.46 & 85.54 & 0.145 & $<0.0001$ \\
\hline Th. marschallianus (I) & 7.68 & 92.32 & 0.077 & $<0.0001$ \\
\hline Th. pannonicus (I) & 9.11 & 90.89 & 0.091 & 0.002 \\
\hline Th. balcanus $(\mathrm{P})$ & 9.95 & 90.05 & 0.100 & $<0.0001$ \\
\hline Th. moesiacus $(\mathrm{P})$ & 11.83 & 88.17 & 0.118 & $<0.0001$ \\
\hline
\end{tabular}

Uzajamne AMOVA analize (Tabela 3.20) su dalje pokazale da je diferencijaija među vrstama bila značajna u svim slučajevima $(\mathrm{P}<0.05)$, osim između $T h$. marschallianus i Th. pannonicus $(\mathrm{P}=0.07)$.

Neighbour-joining analiza (Slika 3.4) je pokazala tri dobro podržane klade: $T h$. pulegioides kladu (Bootstrap podrška [BS] od 94 \%), Th. glabrescens klada (BS 93\%), i klada koja je sadržavala preostale vrste (BS 95 \%). Ova poslednja klada je sadržala dve nepodržane grupe, jednu koja je obuhvatala dve vrste iz podsekcije Isolepides (Th. marschallianus, Th. pannonicus) i drugu u kojoj su bile tri vrste iz podsekcije Pseudomarginati (Th. balcanus, Th. moesiacus, Th. praecox). Pojedinačne jedinke koje pripadaju Th. pannonicus i Th. maschallianus nisu se razdvojile u skladu sa pripadnošću vrstama. S drug strane, vrste iz podsekcije Pseudomarginati su bile jasno razdvojene i dobro podržane, Th. preacox i Th. moesiacus sa BS $100 \%$ i Th. balcanus sa BS $62 \%$. 
Tabela 3.20 Interspecijska $\phi_{\text {ST }}$ vrednost (ispod dijagonale) i srednja vrednost Nei i Lijeve distance (iznad dijagonale) među sedam vrsta roda Thymus. Srednja vrednost intraspeciiske Nei i Lijeve distance data je u dijagonali (u kurzivu)

\begin{tabular}{|c|c|c|c|c|c|c|c|c|}
\hline \multirow{2}{*}{ No. } & \multirow{2}{*}{ Vrsta (Podsekcija) } & \multicolumn{7}{|c|}{ Species } \\
\hline & & 1 & 2 & 3 & 4 & 5 & 6 & 7 \\
\hline 1 & Th. pulegioides (A) & 0.568 & 0.659 & 0.635 & 0.647 & 0.651 & 0.661 & 0.646 \\
\hline 2 & Th. glabrescens (I) & $0.130^{* * *}$ & 0.578 & 0.616 & 0.627 & 0.660 & 0.657 & 0.667 \\
\hline 3 & Th. marschallianus (I) & $0.128^{* * * *}$ & $0.094^{\text {**** }}$ & 0.534 & 0.551 & 0.604 & 0.592 & 0.603 \\
\hline 4 & Th. pannonicus (I) & $0.132^{* * *}$ & $0.097^{* * * *}$ & $0.013^{\mathrm{ns}}$ & 0.553 & 0.613 & 0.603 & 0.611 \\
\hline 5 & Th. balcanus $(\mathrm{P})$ & $0.122^{* * *}$ & $0.126^{* * *}$ & $0.080^{* * *}$ & $0.079^{* * *}$ & 0.575 & 0.612 & 0.624 \\
\hline 6 & Th. moesiacus $(\mathrm{P})$ & $0.168^{* * *}$ & $0.157^{* * *}$ & $0.109^{* * * *}$ & $0.108^{* * *}$ & $0.100^{* * *}$ & 0.521 & 0.629 \\
\hline 7 & Th. praecox $(\mathrm{P})$ & $0.163^{* * *}$ & $0.180^{* *}$ & $0.148^{* *}$ & $0.137^{* *}$ & $0.130^{* *}$ & $0.199^{*}$ & 0.478 \\
\hline
\end{tabular}

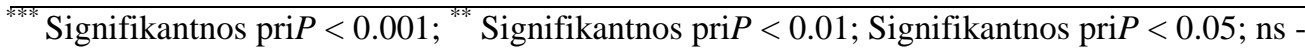

Nesignifikantna vrednost

Procena prosečnog očekivanja podataka, u zavisnosti od datog broja klastera, $\ln [\operatorname{Pr}(X \mid K)]$, se povećavala sa porastom $K$ do $K=5$, dok je standardna devijacija među različitim prolazima za svako K bila relativno niska (Slika 3.5). Ukoliko je K bilo veće od 5, srednje vrednosti za $\ln [\operatorname{Pr}(\mathrm{X} \mid \mathrm{K})]$ su bile niže, dok su varijanse značajnije rasle, pokazujući da su hipoteze o postojanju više od 5 klastera daleko od optimalnih. Kao i u slučaju $\ln [\operatorname{Pr}(\mathrm{X} \mid \mathrm{K})]$, najveće vrednosti $\Delta \mathrm{K}$ su zapažene za $\mathrm{K}=5$. 


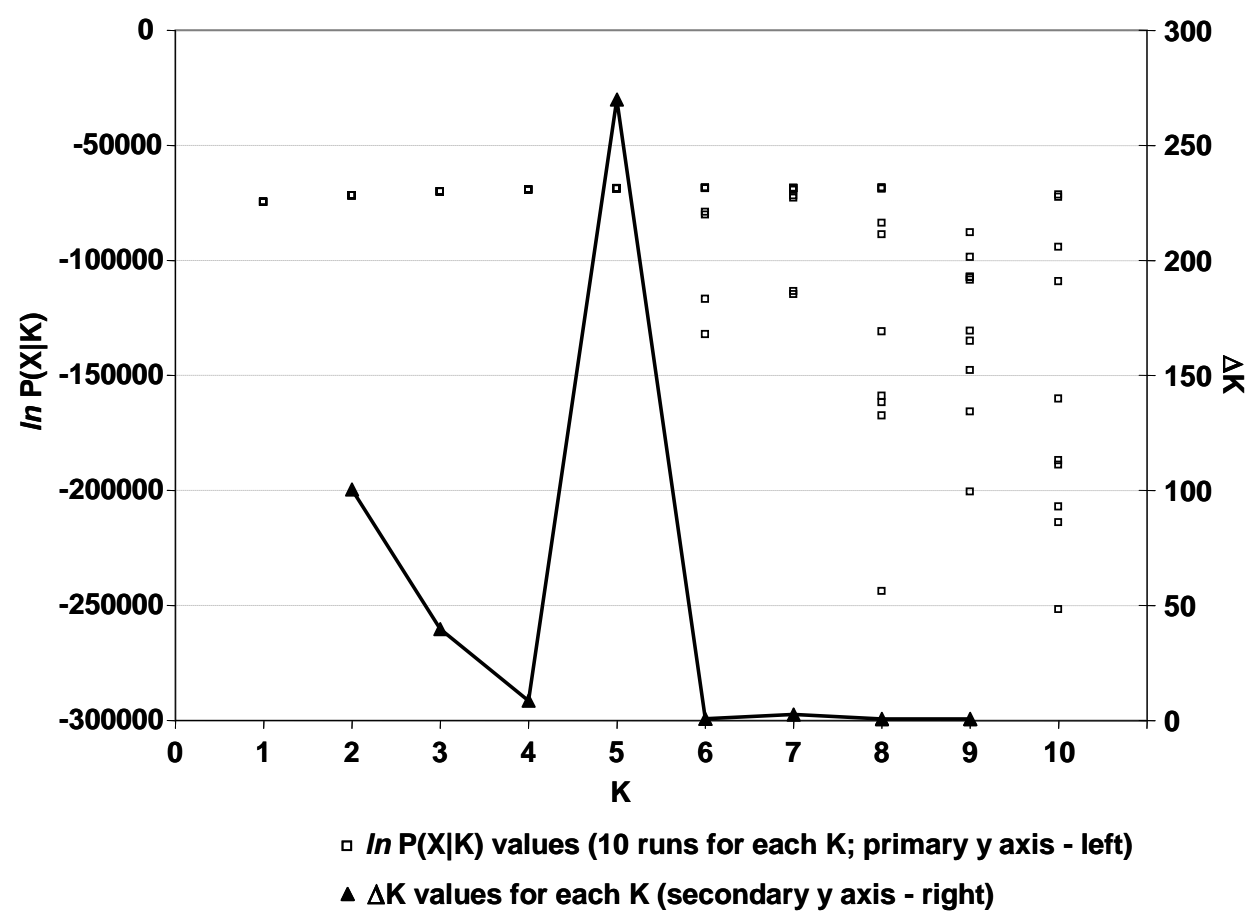

Slika 3.5 Izbor najverovatnijeg broja klastera $(\mathrm{K})$ na osnovu multilokusnih AFLP podataka uz upotrebu model-zasnovanog klastering metoda po Pritchard i sar. (2000): $\ln \mathrm{P}(\mathrm{X} \mid \mathrm{K})$ vrednosti za svaki od deset nezavisnih ranova za svako $\mathrm{K}$ i $\Delta \mathrm{K}$ vrednost za svako $\mathrm{K}$ zasnovano na stopi drugog reda promene funkcije sličnosti sa obzirom na K kako je opisano kod Evanno et al. (2005)

Proporcije pripadnosti svake individue u svakom klasteru su bile izračunate za $K=2$ do $K=5$ zasnovane na prolazu sa najvišim $\ln [\operatorname{Pr}(X \mid K)]$ (Slika 3.5). Kada je $K=2$ sve individue vrste Th. pulegioides su bile izdvojene u zaseban klaster (Klaster A) za razliku od individua svih ostalih vrsta (Klaster B). Za K=3, novoformirani klaster (Klaster C) obuhvatio je jedinke koje pripadaju vrsti Th. glabrescens. Za K=4 je identifikovan dodatni klaster u koji su se delimično izdvojile jedinke vrsta Th. pulegioides, Th. balcanus i Th. glabrescens (Klaster D). Na kraju, za K=5, većina jedinki koje pripadaju Th. marschallianus i Th. pannonicus bila je uključena u novoformirani Klaster E. 


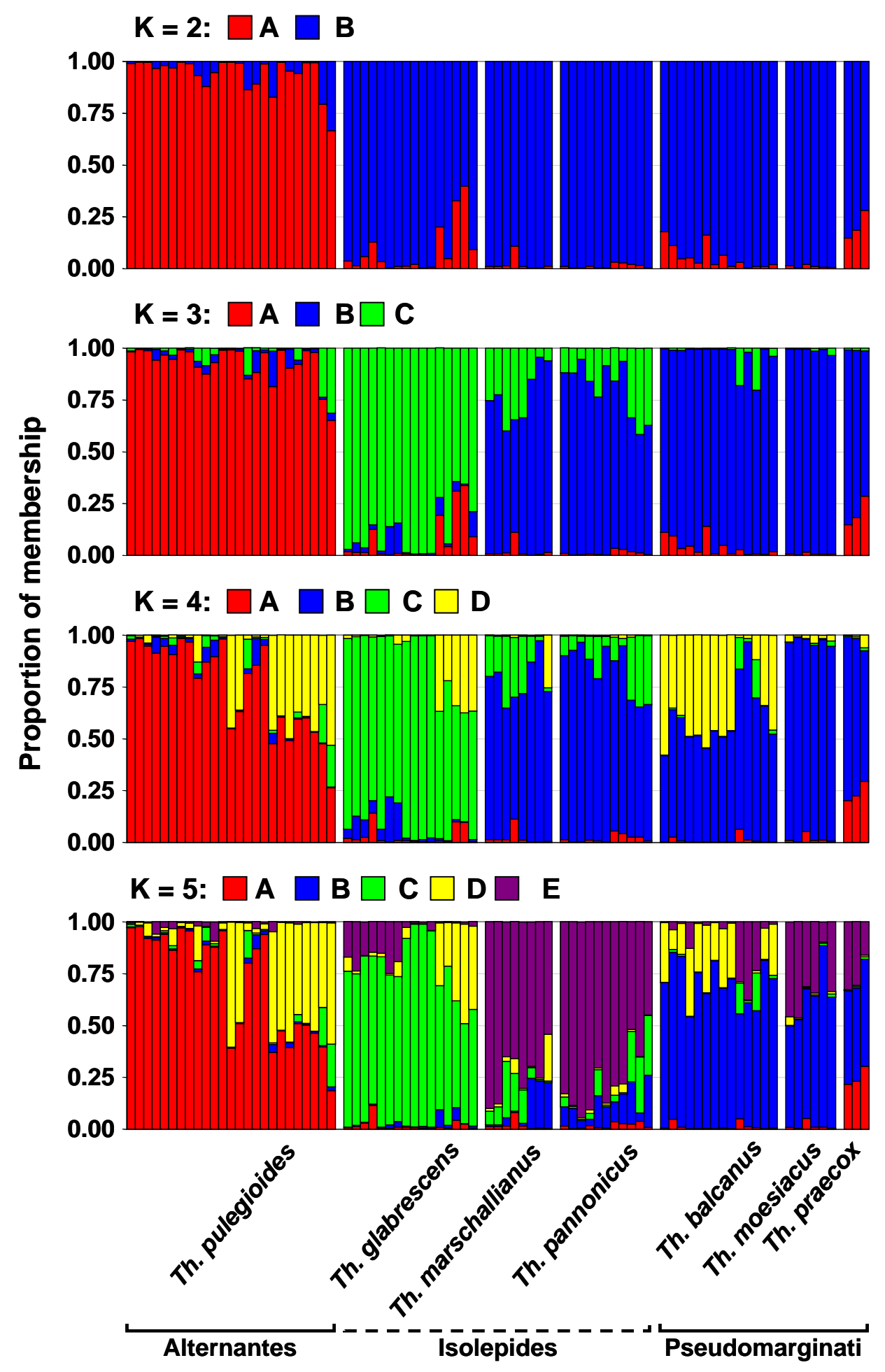

Slika 3.6. Genetička struktura sedam vrsta roda Thymus. Proporcije ućešća za $K=2$ do 5 klastera su date prema proceni programa Structure. Svaka pojedinačna biljka je predstavljena jednom vertikalnom linijom podeljenom bojama. Svaka boja predstavlja po jedan klaster, a dužina pojedine boje predstavlja procenjenu proporciju savake individue u određenom klasteru. Bele linije odvajaju vrste koje su označene ispod slike. 


\section{Diskusija}

\subsection{Sastav etarskih ulja}

Postojanje hemotipova kod samoniklih populacija roda Thymus je dobro poznato, pa tako, na primer, u populacijama Th. vulgaris sa juga Francuske ustanovljeno je postojanje šest hemotipova od kojih svaki nosi naziv po dominnantnom monoterpeunu u etarskom ulju (Passet, 1971; Vernet i sar., 1986).

Kod ispitivanih populacija vrste Th. pulegioides se može konstatovati prisustvo dva jasno definisana hemotipa. Kod populacija P01, P03 i P06 geraniol je u etarskom ulju zastupljen u izuzetno visokom procentu, dok bi se populacije P02, P04, P05 i P09 mogle okarakterisati kao fenolni hemotipovi.

U etarskom ulju populacije P01 geraniol je zastupljen sa 87,12\%, u etarskom ulju populacije P03 sa 87,92\% i u etarskom ulju P06 sa 86,97\%. Ni jedna druga komponenta nije bila prisutna u nekom značajnijem procentu. Geraniol kao glavna komponenta etarskih ulja već je opisan kod nekih populacija Th. pulegioides (Mockuté i Bernotiené, 1998, 1999, 2001; Mastelic i sar., 1992; Karuza-Stojakovic i sar., 1989). Populacije P01, P03 i P06 PCA1 osa odvaja u posebnu grupu, upravo na osnovu visoke koncentracije geraniola (Graf. 3.1). Slične rezultate da je i primena klaster analize, gde ove tri formiraju klaster A (Slika 3.1).U etarskim uljima P02, P04, P05 i P09 je visoka koncentracija jedinjenja koja pripadaju istom metaboličkom putu, tj. $p$-cimen i $\gamma$ terpinen su prekursori u sintezi timola i karvakrola, tako da se ova jedinjenja uvek javljaju zajedno. Ukupan sadržaj ovih komponenti se kretao od 71,02\% kod P09 do $84,50 \%$ kod P05. U etarskom ulju populacije P02 timol je glavna komponenta sa $52,95 \%$, dok je koncentracija $p$-cimena $4,89 \%$ i $\gamma$-terpinena $21,39 \%$. Kod populacije P04 karvakrol je u etarskom ulju zastupljen sa 39,95\%, dok je p-cimen glavna komponenta sa $42,59 \%$, a $\gamma$-terpinen učestvuje $1,51 \%$. Ovo je jedina populacija sa visokom koncentracijom karvakrola. Kod populacije P05 glavna komponenta etarskog ulja je timol sa $62,82 \%$, dok su $p$-cimen i $\gamma$-terpinen zastupljeni sa $17,36 \%$, odnosno sa 3,31\%. U etarskom ulju populacije P09 najzastupljenija komponenta je $p$-cimen sa 
48,59\%, dok je timol zastupljen sa 22,12\%, a $\gamma$-terpinen sa $0,27 \%$. Na osnovu sadržaja sastojaka etaraskog ulja, PCA2 osa razdvaja ove populacije na dve grupe, one sa timolom i $\gamma$-terpinenom i one sa karvakrolom i $p$-cimenom (Grafik 3.1). Slični rezultati dobijeni su i primenom klaster analize. P02, P05 i P09 grupišu se u klaster B, dok se P04 nalazi u klasteru C (slika 3.1). Timol i karvakrol su najvažnije komponente etarskih ulja kod vrsta roda Thymus i javljaju se kod velikog broja taksona, najčešće u koncentracijama između 20 i 50\% (Thompson, 2002). Ovo je slučaj i sa mnogim ispitivanim populacijama vrste $T h$. pulegioides koje su pripadale fenolnom hemotipu. Kod ispitivanih populacija iz Litvanije konstatovano je prisustvo i timolnog i karvakrolnog hemotipa (Ložienè i sar., 2003). Kod populacija sa Britanskih ostrva, takođe su opisani i timolni i karvakrolni hemotip (Stahl-Biskup, 1986), kao i kod populacija iz Hrvatske (Kuštrak i sar., 1990).

Sve ispitvane populacije vrste Th. glabrescens mogu se po sastavu etarskih ulja okarakterisati kao fenolni hemotip. Sve ispitivane populacije u etarskim uljima imale su visoke koncentracije $p$-cimena, $\gamma$-terpinena i timola. Ukupan sadržaj ove tri komponente se kreće od 57,06\%, kod P12, do 80,60\%, kod P13. Kod populacije P10 timol predstavlja 56,29\% etarskog ulja, dok su $p$-cimen i $\gamma$-terpinen zastupljeni sa $9,76 \%$, odnosno 11,91\%. Kod P11 timol je takođe glavna komponenta sa 61,94\%, a $p$-cimen i $\gamma$-terpinen su zastupljeni sa $11,40 \%$, odnosno $2 \%$. U etarskim uljima P12, $\gamma$-terpinen je najzastupljenija komponenta sa 19,61\%, dok je timol drugi sa 19,02\%, p-cimen je zastupljen sa $18,43 \%$. Kod ove populacije značajno je zastupljen i timol metil etar sa 13,11\%. Kod populacije P13 timol je najzastupljenija komponenta etarskog ulja sa $64,51 \%$, a slede $\gamma$-terpinen sa $10,67 \%$ i $p$-cimen sa 5,38\%. Glavna komponenta etarskog ulja populacije P14 je $p$-cimen sa $42,56 \%$, dok su timol i $\gamma$-terpinen zastupljeni sa 16,56\%, odnosno 13,25\%. Kod populacije P15 u etarskom ulju najzastupljenija komponenta je timol sa $44,53 \%$, prati ga $\gamma$-terpinen sa $31,26 \%$, dok je $p$-cimen zastupljen sa 3,98\%. Kod populacije P33 glavna komponenta etarskog ulja je $p$-cimen sa $75,76 \%$, dok timol i $\gamma$-terpinen imaju male koncentracije od $1,03 \%$, odnosno $0,92 \%$. PCA1 osa na osnovu visokog sadržaja timola, $\gamma$-terpinena, $p$-cimena i timol metil etra grupiše sve populacije vrste Th. glabrescens, dok PCA6 daje razdvajanje populacije ove vrste na one koje imaju više koncentracije p-cimena i timol metil etra i one koje imaju više koncentracije timola i $\gamma$-terpinena (Grafik 3.2). Slično grupisanje populacija ove 
vrste dobijeno je i klaster analizom, gde se populacije Th. glabrescens izdvajaju u klaster A, u okviru kojeg se razlikuju podklasteri $\mathrm{A}_{1}$, sa populacijama P12, P14 i P33, i podklaster $\mathrm{A}_{2}$, sa populacijama P10, P11, P13 i P15 (Slika 3.2). Timol je daleko najznačajniji sastojak etarskih ulja kod roda Thymus (Thompson, 2002) i javlja se kod mnogih vrsta kao glavna komponenta (Kulevanova i sar., 1996c; Dajic Stevanovic i sar., 2008). Kod nekih populacija vrste Th. zygis timol se javljao u koncentraciji od 30,7\%, dok je p-cimen bio zastupljen sa 23,3\% (Richard i sar., 1985). Kod nekih populacija vrste Th. longicaulis timol je činio 40,1\% etarskog ulja, a p-cimen 26,3\% (Kuštrak i sar., 1990). Kod Th. tosevii ssp. substriatus timol je predstavljao 24,5\%, odnosno 45,6\% etarskog ulja (Kulevanova i sar., 1997). Kod svih ispitivanih populacija vrste $T h$. marschallianus germakren-D je glavna komponenta, tako da se može konstatovati da je, što se tiče sastava etarskog ulja, ovo jedna homogena grupa. Kod populacije P16 germakren-D je zastupljen sa 34,00\%, kod populacije P17 sa 20,40\% i kod populacije P18 sa 66,66\%. Na grafiku 3.2 se vidi da se na osnovu PCA1 ose grupišu sve populacije Th. marschallianus, kao i jedna populacija Th. pannonicus (P20), koja sadrži visoku koncentraciju germakrena-D. U UPGMA dendogramu ove populacije formiraju klaster B (Slika 3.2). Thompson (2002) navodi da je ovo jedinenje često prisutno u etarskim uljima kod roda Thymus, ali da retko prelazi 10\%, ovaj hemotip je opisan kod populacija Th. bracteosus sa zapadnog Balkana (Bucar i sar., 2005; Slavkovska i sar., 2006). Kod populacije P16 biciklogermakren je zastupljen sa $12,30 \%$, a (E)- $\beta$-ocimen sa $9,75 \%$, kod populacije P17 jedino još $(E)$-kariofilen ima značajnu zastupljenost sa 14,57\%, a kod populacije P18 $\alpha$-pinen je zastupljen sa 11,29\%.

Ispitivane populacija vrste Th. pannonicus su raznovrsne, što se tiče sastava etarskog ulja. U literaturi su do sada navedena tri hemotipa ove vrste, $\alpha$-terpinil acetat (Karuza-Stojakovic i sar., 1989), timol/p-cimen (Pluhár i sar., 2007) i geranial/neral (Maksimović i sar., 2008a).

Kod populacije P19 $\alpha$-pinen, koji se navodi kao komponenta zastupljena sa više od $10 \%$ u etarskim uljima samo deset ispitivanih taksona ovog roda, je najzastupljenija komponenta sa 19,90\% (Thompson, 2002), ova komponenta je glavni sastojak etarskih ulja još samo kod nekih populacija Th. baeticus sa Iberijskog poluostrva (Morales, 1986) Takođe, još dva monoterpenska ugljovodonika su prisutna u koncentracijama preko $10 \%$, limonen $(12,45 \%)$ i (E)- $\beta$-ocimen $(14,23 \%)$, dok su kamfen i mircen 
zastupljeni sa 4,03\% odnosno 4,81\% i uz još devet komponenti čine da je ova grupa jedinjenja najzastupljenija. Na PCA biplotu ova populacija se nije izdvojila ni pojednoj osi, a takođe u u UPGMA dendogramu ne pripada niti jednom klasteru (Slika 3.2). U etarskom ulju ove populacije je relativno visoka koncentracija dva oksigenovana monoterpenska ugljovodonična derivata, 1,8-cineola i kamfora. Ove dve komponente se često javljaju zajedno u etarskim uljima različitih vrsta roda Thymus (Morales, 1986).

U etraskom ulju populacije P20 monoterpenski ugljovodonici predstavljaju značajnu grupu jedinjenja s obzirom da je $\alpha$-pinen zastupljen sa $13,88 \%$, mircen i (E)- $\beta$ ocimen takođe imaju zastupljenost od preko 5\%. U ulju ove populacije oksigenovani monoterpenski ugljovodonici nisu prisutni u značajnom procentu dok s druge strane, iako se seskviterpenski ugljovodonici ne smatraju značajnom komponentom etarskih ulja kod roda Thymus (Thompson, 2002), germakren-D je najzastupljenija komponenta sa $36,91 \%$. PCA pokazuje da je po sastavu etarskog ulja ova populacija bliska populacijama vrste Th. marschallianus, tako da i na UPGMA dendogramu ulazi u klaster B (Slika 3.2).

Kod populacije P21 u etarskom ulju linalool je glavna komponenta sa 66,06\%, a veću koncentraciju ima još i $\beta$-bisabolen sa 7,76\%. Kod ove populacije su takođe prisutni i 1,8-cineol i kamfor sa 2,73\%, odnosno 6,01\%. Na osnovu visokog sadržaja linaloola ova populacija se izdvaja na PCA6 osi (Grafik 3.2), dok je na UPGMA dendogramu u klasteru F (Slika 3.2). Linalool je bio značajna komponenta i kod nekih drugih populacija vrsta roda Thymus. Kod Th. pulegioides iz Austrije linalool je bio zastupljen između 33,4 i 92,3\% (Mártonfi i sar., 1994), kod nekih populacija Th. mastichina takođe je bio glavna komponenta, i koncentracija mu se kretala između $74 \%$ (Adzet i sar., 1977a, b) i 82,9\% (García Vallejo i sar., 1984). Kod tri ispitivana varijeteta Th. jankae (var. jankae, var. pantotrichus i var. patentipilus) linalool je bio glavna komponenta i njegova koncentracija u etarskim uljima se kretala od 28,1 do $31,2 \%$ (Kulevanova i sar., 1998a).

Kod populacije P22 (E)-kariofilen predstavlja glavnu komponentu etarskog ulja sa zastupljenošću od 40,30\%. Značajno je prisustvo još dva monoterpenska ugljovodonika, limonena sa $24,82 \%$ i (E)- $\beta$-ocimena sa $6,56 \%$. PCA odvaja ovu populaciju od ostalih populacija iz podsekcije Isolepides na osnovu PCA4 ose, odnosno zbog visoke koncentracije (E)-kariofilena i limonena (Grafik 3.2). U klaster analizi ova 
populacija formir klaster E. Iako seskviterpenski ugljovodonici nisu značajna komponenta etarskih ulja kod roda Thymus, (E)-kariofilen je svakako najrasprostranjeniji (Thompson, 2002). Kod određenog broja taksona (E)-kariofilen je prelazio koncentraciju od 10\%, kod nekih populacija Th. praecox ssp. arcticus iz Britanije predstavljao je 31,5\%, kod Th. pulegioides iz Litvanije od 11,4 do 15,9\% (Mockuté i Bernotiené, 1998, 1999, 2001), iz Hrvatske 11,5\% (Kuštrak i sar., 1990), iz Mađarske od 14,8 do 29,6\% (Mártonfi i sar., 1994), kod Th. alpestris iz Slovačke 10,5\% (Mártonfi, 1992), ali ni u jednom slučaju nije predstavljao glavnu komponentu.

Kod populacije P23 dominantna komponenta etarskog ulja je citral (geranial i neral) koji čini 85,80\% ukupnog etarskog ulja. Ovaj nalaz je saglasan sa prethodnim istraživanjima ove vrste sa istog područja gde je citral činio 71,03\% etarskog ulja (Maksimović i sar., 2008a). PCA3 osa odvaja ovu populaciju od ostalih (Grafik 3.2), a na UPGMA dendogramu $\mathbf{P 2 3}$ formira klaster D (Slika 3.2). U etarskom ulju ove populacije ni jedna druga komponenta nije imala značajan procenat zastupljenosti.

Kod populacije P34 dominantna komponenta etarskog ulja je mircen sa 25,85\%, a značajno su zastupljeni još i $\alpha$-terpineol $(20,01 \%)$ i $(E)$-kariofilen $(11,75 \%)$. Na osnovu PCA2 ose ova populacija se izdvaja od ostalih (Grafik 3.2). I na UPGMA dendogramu ova populacija formira klaster C (Slika 3.2). Koncentracija mircena od preko $10 \%$ je do sada opisana kod svega 11 taksona roda Thymus (Thompson, 2002), s time da je bio glavna komponenta kod nekih populacija vrste Th. granatensis (Cabo i sar., 1986a, b), Th. hyemalis (Cabo i sar., 1987) i Th. mastigophorus (Velasco Negueruela i Pérez-Alonso, 1986).

Kod svih ispitivanih populacija vrste Th. balcanus javljaju se dva hemotipa. Kod P25 u etarskim uljima su dominantne komponente geranial i neral, što ovu populaciju svrstava u citralni hemotip. U etarskom ulju ove populacije značajnu koncentraciju ima još i neril acetat sa 12,45\%. PCA1 osa odvaja ovu populaciju upravo zbog visoke koncentracije nerala, geraniala i neril acetata (Grafik 3.3), dok u UPGMA dendogramu formira klaster D (Slika 3.3). Kod populacija P24, P26 i P27 najznačajnije su komponente linalil acetat, linalool i mircen. PCA1 osa odvaja ove populacije od oszalih na osnovu koncentracije ovih komponenti (Grafik 3.3), a na UPGMA dendogramu formiraju klaster A (Slika 3.3). U etarskom ulju populacije P24 najzastupljenija komponenta je linalil acetat sa 22,94\%, dok je linalool zastupljen sa $11,74 \%$, a mircen 
sa 18,08\%. Kod populacije P26 najzastupljenija komponenta etarskog ulja je, takođe, linalil acetat sa $33,89 \%$, a slede linalol sa $17,05 \%$ i mircen sa $7,51 \%$. Kod ove populacije značajna komponenta etarskog ulja je i biciklogermakren sa $11,88 \%$. U etarskom ulju populacije P27 najzastupljenija komponenta je linalool sa 34,42\%, a slede linalil acetat sa $14,56 \%$ i mircen sa $14,24 \%$. Ovakav hemotip koji se karakteriše značajnim učešćem linaloola i linalil acetata je opisan kod nekih populacija taksona sa Iberijskog poluostrva, Th. leptophyllu ssp. leptophyllu (Blázquez i sar., 1989), Th. zygis (García Martín i GarcíaVallejo, 1983) i Th. camphoratus (Salgueiro i sar., 1997a).

Kod ispitivane populacije vrste Th. moesiacus P31, najzastupljenija komponenta etarskog ulja je $\alpha$-terpinil acetat, pri čemu ni jedna druga komponenta ne prelazi koncentraciju od 10\%. PCA3 osa jasno odvaja ovu populaciju od ostalih iz podsekcije Pseudomarginati na osnovu koncentracije $\alpha$-terpinil acetata (Grafik 3.3), dok na UPGMA dendogramu formira klaster B (Slika 3.3). Ovaj hemotip je odsta redak kod vrsta roda Thymus i javlja se kod nekih populacija Th. herba-barona (Corticchiato i sar., 1998), kao i kod Th. longicaulis (Grujić Jovanović i sar., 2009).

Kod ispitivane populacije vrste Th. praecox $\mathbf{P 3 2}$ glavna komponenta etarskog ulja je $(E)$-kariofilen sa $20,48 \%$, dok je $\gamma$-kadinen zastupljen sa $17,84 \%$. koji se ne navodi kao komponenta koja prelazi $10 \%$ ni kod jedne isopitivane populacije. Ova populacija se odvaja na PCA2 osi na osnovu koncentracije ove dve komponente, dok na UPGMA dendogramu formira klaster $\mathrm{C}$.

Postojanje hemotipova kod roda Thymus je poznato i dobro dokumentovano i samatra se da se na rasprostranjenje hemotipa imaju uticaj ekološki faktori (Thompson i sar., 2003). Poznavanje hemotipa određene populacije je od značaja s obzirom da etarska ulja biljaka mogu imati različite biološke aktivnosti. Biološka aktivnos etarskih ulja ispitivana je kod mnogih vrasta roda Thymus i pokazano je da imaju izrazita antibakterijska i antifungalna svojstva (Sakagami i sar., 2005; Kizil i Uyart, 2006; Saad i sar, 2010) koja su posledica prisustva fenolnih komponenti timola, karvakrola, $\gamma$ terpinena i p-cimena (Nedorostova i sar., 2008). Kod populacija Th. glabrescens je utvrđeno da antioksidativna svojstva zavise od koncentracije fenolnih komponenti etarskog ulja (Maksimović i sar., 2008b). 


\subsection{Površinski flavonoidi}

U Tabeli 3.16 se zapaža da se na osnovu sastava površinskih flavonoida ispitivane populacije vrsta roda Thymus sa područja Srbije mogu podeliti u dve grupe.

Prvoj grupi bi pripadale vrste koje imaju niske i srednje količine površinskih flavonoida, kao i one kod kojih su se površinski flavonidi nalazili samo u tragovima. Kod ove grupe su najzastupljeniji flavoni sa 5,6-diOH-7-OMe i 5,6-diOH-7,8-diOMe supstitucionom šemom u A prstenu. U drugu grupu bi se mogle svrstati populacije koje, uglavnom, imaju malu količinu površinskih flavonoida i kod kojih je su najzastupljeniji flavoni sa 5-OH-6,7-diOMe i 5-OH-6,7,8-triOMe supstitucionom šemom u A prstenu.

Većina ispitivanih populacija Th. pulegioides (podsekcija Alternantes), po prisustvu površinskih flavonoida pripada prvoj grupi vrsta. Kod populacija P02, P03, P04, P05 i P09 najzastupljeniji flavon je 5,6,-diOH-7,3',4'-triOMe, dok je drugi po zastupljenosti 5,6-diOH-7,8,3',4'-tetraOMe. Kod populacije P06, ova dva jedinjenja su u obrnutom odnosu, a kod populacije P01, je luteloin bio najzastupljenija komponenta. Luteolin se javlja kao komponenta druga po zastupljenosti i kod P03 i P04, dok je kod P06 i timonin dobro zastupljen. Ovi rezultati su u saglasnosti sa rezultatima koje su dobili Marin i sar. (2003), koji su ispitivali vrste roda Thymus iz Makedonije. Kod Th. pulegioides iz Makedonije najzastupljeniji površinski flavon je takođe bio 5,6,-diOH7,3',4'-triOMe, dok je drugi po zastupljenosti bio ladanein, koji je u većini uzoraka iz Srbije prisutan, ali ne u velikom procentu. Kod uzoraka Th. pulegioides sa Pirinejskog poluostrva glavni površinski flavonoid je bio 5,4'-diOH-6,7-diOMe (cirsimaritin), a 5,6,4'-triOH-7,8-diOMe (timusin) i 5,6,4'-triOH-7,8,3'-triOMe (timonin) su takođe bili važne komponente u ovim uzorcima (Hernández i sar., 1987). Ni jedan od ovih površinskih flavonoida se nije nasao ni u tragovima kod populacija iz Srbije, osim timonina, što je već pomenuto kod P06. Ovo dodatno ukazuje, kako su naveli Marin i sar. (2003), da u okviru ove vrste koja ima široko rasprostranjenje postoji izražena infraspecijska varijabilnost.

Iz podsekcije Isolepides su ispitivane populacije vrsta Th. glabrescens, Th. marschallianus i Th. pannonicus. U okviru ove podsekcije ispitivane vrste pripadaju obema grupama. 
Kod ispitivanh populaciaj Th. glabrescens glavni površinski flavon je 5,6,diOH-7,3',4'-triOMe, a još su značajno zastupljeni i 5,6-diOH-7,4'-diOMe (ladenein) i 5,6-diOH-7,8,3',4'-tetraOMe. Izuzetak je samo P12 kod koje je glavni površinski flavonoid 5,6-diOH-7,8,4'-triOMe (pebrellin), koji je kod ostalih populacija prisutan ali ne u velikoj količini. Kod uzorka Th. glabrescens iz Makedonije glavni površinski flavonoid je bio 5,6-diOH-7,8,3',4'-tetraOMe, a zanačajni su bili i 5,6,-diOH-7,3',4'triOMe i 5,6-diOH-7,8,4'-triOMe (pebrellin) (Marin i sar., 2003).

Kod populacija vrste Th. marschallianus P17 i P18 dominantan površinski flavonoid je 5-OH-6,7,4'-triOMe (salvigenin), a drugi po zastupljenosti je 5-OH6,7,8,4'-tetraOMe (gardenin B). Kod populacije P16 dominantan je 5-OH-6,7,8,4'tetraOMe (gardenin B), drugi je 5-OH-6,7,4'-triOMe (salvigenin). Kod P18 je takođe utvrđeno prisustvo i flavanona eriodiktiola i metoksilovanih flavanona.

$\mathrm{Za}$ ispitivane populacije Th. pannonicus utvrđena je niska količina, osim kod P23 gde je bila srednja, kao i velika varijabilnosti u sastavu površinskih flavonoida. Kod P19 i P20 dominantan je flavon je 5-OH-6,7,4'-triOMe (salvigenin), dok je drugi po značaju 5-OH-6,7,8,4'-tetraOMe (gardenin B). Populacija P34 ima 5-OH-6,7,8,4'tetraOMe (gardenin B) kao dominantan flavon, dok je 5,6-diOH-7,8,4'-triOMe (pebrellin) drugi po značaju. Kod populacije P23 5,6,4'-triOH-7,8-diOMe (thymusin) je dominantan, a drugi po količini su 5,6,4'-triOH-7,3'-diOMe i 5,6,-diOH-7,3',4'-triOMe. Kod P22 su prisutni 5,4'-diOH-6,7,8-triOMe (xanthomicrol) i 5-OH-6,7,8,4'-tetraOMe (gardenin B), a kod P21 5,6-diOH-7,8,4'-triOMe (pebrellin) i 5-OH-6,7,8,3',4'pentaOMe (5-desmethylnobiletin), u malim količinama. Kod populacija Th. pannonicus prisutni su i metoksilovani flavanoni, osim kod P23 i P34.

Podela podsekcije Isolepides na dve grupe prema flavonoidnim profilima ukazuje da se Th. glabrescens izdvaja od druge dve vrste iz ove podsekcije, ali i da je ova vrsta sličnija po profilu površinskih flavonida vrsti Th. pulegioides., od kojih se razlikuje po nešto većim količinama ladaneina. Vrste Th. marschallianus i Th. pannonicus jasno pripadaju drugoj grupi po flavonoidnom profilu. Iz ove grupe se izdvaja P23 koja je jedina od ispitivanih populacija kod koje je glavni flavon timusin, što je značajan flavon kod vrsta roda Thymus sa Iberijskog poluostrva (Horwath i sar., 2008; Hernández i sar., 1987; Corticchiato i sar., 1995). 
Kod ispitivanih vrsta iz podsekcije Pseudomarginati količina površinskih flavonoida je mala ili samo u tragovima. Kod sve četiri populacije Th. balcanus, P24, P25, P26 i P27, najzastupljeniji je 5,6-diOH-7,8,4'-triOMe (pebrellin), a značajan je još i 5,6-diOH-7,8,3',4'-tetraOMe. Marin i sar. (2003) su u svom radu uključili bili tri varijeteta vrste Th. balcanus iz Makedonije. Kod Th. balcanus var. balcanus glavni površinski flavonoid je bio 5,6-diOH-7,8,4'-triOMe (pebrellin), a kod Th. balcanus var. vandasii i Th. balcanus var. micevskii glavni površinski flavonoid je bio 5-OH-6,7,8,4'tetraOMe (gardenin B), koji kod uzoraka iz Srbije nije pronađen ni u tragovima. Kod uzoraka iz Makedonije je značajno bio zastupljen i 5-OH-6,7,8,3',4'-pentaOMe (5desmethylnobiletin) koji kod uzoraka iz Srbije nije konstatovan ni u tragovima. Kod populacije vrste Th. moesiacus, P31, utvrđeno je prisustvo male kolčine površinskih flavonoida i po prisustvu 5,6-diOH-7,8,4'-triOMe (pebrellin) i 5,6-diOH-7,8,3',4'tetraOMe pripadaju istom flavonoidnom profilu kao i Th. balcanus, mada je luteolin iamo najveću prisutnost. Kod Th. moesiacus var. moesiacus iz Makedonije najznačajniji je bio 5,6,-diOH-7,3',4'-triOMe (Marin i sar., 2003) što ga, po sastavu površinski flavonoida čini sličnijim Th. pulegioides i Th. glabrescens iz Srbije. Kod Th. praecox je determinisana mala količina flavonoida i kao dominantan se javlja 5-OH-6,7,4'-triOMe (salvigenin), a utvrđeno je još i prisustvo 5-OH-6,7,8,4'-tetraOMe (gardenin B), kao i prisustvo metoksilovanih flavanona, što nije slučaj ni kod jedne druge vrste iz ove podsekcije. Ovakav flavonoidni profil približava ovu populaciju ispitivanim populacijama vrsta Th. marschallianus i nekim populacijama Th. pannonicus. Ovakva razlika između flavonoidnih profila $T h$. balcanus i $T h$. moesiacus, s jedne strane i $T h$. praecox, s druge, ukazuje da njihovo grupisanje u Th. praecox agregat treba preispitati. I kod populacija iz Makedonije došlo je do razdvajanja vrsta iz ovog agregata i do grupisanja u različite flavonoidne profile (Marin i sar., 2003). Gardenin B je bio važan flavon i kod nekih ispitivanih populacija Th. striatus iz Crne Gore (Marin i sar., 2005), vrsti koja pripada sekciji Hyphodromi, dok je kod Th. praecox sa Pirinejskog poluostrva glavni površinski flavonoid 8-methoxycirsilineol, uz značajne količine cirsiliola i 5desmethylnobiletin i 5-desmethylsinensetina (Hernández i sar., 1987). Analiza populacija vrsta Thymus hyemalis i Thymus baeticus kao i velikog broja njihovih putativnih hibrida iz jugoistočne Španije pokazala je zavisnost površinskih flavonnida i lokaliteta (Horwath i sar., 2008). Veza između flavonoidnog profila, lokaliteta i 
klimatskih uslova takođe je utvrđena i kod Parahebe catarractae (Grayer-Barkmeijer, 1978), roda Phlomis (Tomás i sar., 1986) i kod Mimulus aurantiacus (Hare, 2002).

\subsection{AFLP analiza}

U ranijim ispitivanjima vrsta roda Thymus, analiza ITS markera (Internal Transcribed Spacer) se pokazala neprikladnom za rešavanje filogenetskih odnosa između vrsta ovoga roda sakupljenih na području Srbije (Dajić Stevanović i Šoštarić, 2006), mada je ITS uspešno korišćen pri analizi nekih bliskih rodova iz familije Lamiaceae (Jamzad et al., 2003). Na višim taksonomskim nivoima upotreba AFLP markrea za rešavanje filogenetskih odnosa se ponekad smatra kontoverznom zbog mogućeg visokog nivoa homoplazija (Meudt and Clarke, 2007), ali s druge strane, na nižim taksonomskim nivoima AFLP analiza se pokazala izuzetno korisnom za donošenje procena o filogenijama koje nisu dovoljno rešene upotrebom DNK sekvenci kada varijacija između sekvenci nije izražena (Beardsley et al., 2003; Després et al., 2003; Safer et al., 2011). Ovom prilikom, pri ispitivanju taksona roda Thymus iz Srbije, upotreba AFLP markera se čini prikladnom za utvrđivanje komplikovanih odnosa koji uključuju i česte slučajeve hibridizacije između različitih vrsta. Poređenjem granica taksona roda Thymus kako su date u Flori SR Srbije (Diklić, 1974) i Flora Europaea (Jalas, 1972) vidljivo je veliko neslaganje, kako u morfološkim karakteristikama pojedinih vrsta, tako i u rasprostranjenju odrđenih vrsta u Evropi.

Th. pulegioides pripada podsekciji Alternantes i u Flora Europaea i u Flori SR Srbije ovaj takson ima iste okvire. Takođe, prema oba izvora široko je rasprostranjen $u$ Evropi. Sve ispitivane jedinke vrste Th. pulegioides formiraju posebanu kladu koja ima visoku bootstrap podrušku i ujedno cela ova grupa je najviše divergirala od ostalih vrsta koje su uključene u ovu analizu, sa najvišom srednjom $\phi_{S T}$ vrednošću. Za $K=2$ sve jedinke se grupišu u Klaster A, čime su izdvojene od ostalih jedinki. Genetička izdvojenost vrste Th. pulegioides je podržana i morfološkim karakterima, pošto je za ovu vrstu karakeristično gonotrihno stablo po čemu se lako razlikuje od ostalih vrsta uključenih u ovo ispitivanje.

Prema dobijenim rezultatima podsekcija Isolepides je polifiletska, mada su morfološke razlike među obuhvaćenim vrstama veoma male. Prema Flora Europaea 
vrsta Th. glabrescens ima rasprostranjenje u centralnoj i jugo-istočnoj Evropi i Turskoj. Klada koja obuhvata jedinke ove vrste ima visoku bootstrap podršku. Za K=3 sve jedinke vrste Th. glabrescens su grupisane u Klaster B.

Th. marschallianus se u Flora Europaea tretira kao sinonim za Th. pannonicus, koji je opisan kao vrsta sa rasprostranjenjem u centralnoj i jugo-istočnoj Evropi. Klada koju formiraju jedinke koje pripadaju Th. marschallianus i Th. pannonicus nema bootstrap podršku veću od 50\% i jedinke ove dve vrste su međusobno izmešane. AMOVA pokazuje da je $\phi_{\text {ST }}$ vrednost između ove dve vrste veoma niska, što ukazuje da ove dve vrste međusobno nisu diferencirane. Za $\mathrm{K}=5$ jedinke obe vrste su pretežno svrstane u Klaster E.

Morfološke razlike između Th. glabrescens i Th. maschallianus veoma male i njihovo grupisanje u različite klade je neočekivano. Međutim, i ranije je utvrđeno da su unutar ove grupe taksonomski odnosi veoma nejasni (Marin i sar., 2003). Th. marschallianus i Th. pannonicus se morfološki jasno razlikuju po indumentumu na listovima, dok su kod Th. pannonicus listovi prekriveni višećelijskim nežlezdanim dlakama; listovi kod Th. marschallianus su goli. Slična situacija je uočena i kod irskih populacija Quercus petrea i $Q$. robur, koje su se znatno bolje razlikovale na osnovu morfoloških karaktera nego analizom molekularnih markera (AFLP) (Kelleher i sar., 2005). Bez obzira na ovu jasnu morfološku razliku ove dve vrste roda Thymus, su genetički nedovoljno različite, što podržava pristup iz Flora Europaea da se tretiraju kao jedna vrsta.

Unutar podsekcije Pseudomarginati i Jalas, (1972) (Flora Europaea) i Diklić (1974) i (Flora SR Srbije) navode da je prisutana velika morfološka varijabilnost, kako između vrsta, tako i unutar samih vrsta. Jedinke sve tri vrste iz ove podsekcije, koje su uključene u ovo ispitivanje, formiraju monofiletsku kladu, koja ipak nije podržana visokom bootstrap vrednošću, dok su, s druge strane, na nivou vrste, Th. balcanus, Th. praecox i Th. moesiacus dobro podržani. $\mathrm{Za} \mathrm{K}=5$ jedinke ove tri vrste su pretežno grupisane u Klaster B.

Prema Jalas-u (1972) Th. balcanus je opisan kao Thymus praecox Opiz subsp. polytrichus (A. Kern. ex Borbás) Jalas, vrsta sa alelotrihnim stablom i rasprostranjenjem u južnojEvropi i južnom delu centralne Evrope. Prema istom izvoru Th. praecox, kako je opisan u Flori SR Srbije, je Thymus praecox Opiz subsp. skorpilii (Velen.) Jalas, 
vrsta sa holotrihnim stablom i rasprostranjenjem u severnim i centralnim delovima Balkanskog poluostrva. Jedinke vrsta Th. balcanus i Th. praecox su se odvojeno grupisale. Takođe, $\phi_{S T}$ vrednost između ove dve vrste je visoka, što ukazuje na postojanje genetičke diferencijacije između ove dve vrste. Th. moesiacus je u Flora Europaea opisan kao Th. longicaulis C. Presl, vrsta sa alelotrihnim stablom i rasprostranjenjem u centralnoj i jugo-istočnoj Evropi.

Pri proučavanjima blisko srodnih, međusobno ukrštajućih vrsta, utvrđeno je da je najveći deo genetička varijabilnost, dobijena analizom AFLP markera, unutar samih vrsta, a ne između vrsta. U slučaju četiri vrste iz roda Quercus preko $90 \%$ varijabilnosti je utvrđeno unutar samih vrsta (Dodd i Kashani, 2003 ). Između populacija svih analiziranih vrsta je primećena visoka vrijabilnost (Tabela 3.19), dok je komponenta varijabilnosti između vrsta bila relativno niska, što ukazuje da diferencijacija između vrsrta nije izražena (Tabela 3.18). Razlog za ovo može biti ili brza evolucija AFLP markera ili retikulatna evolucija. Ova druga hipoteza je verovatnija, naročito ukoliko se ima u vidu da reproduktivna izolacija između vrsta sekcije Serpyllum gotovo da ne postoji (Morales, 2002). Vrste uključene u ovo ispitivanje odaju utisak izraženog retikulatnog sistema, koji se javlja često kod blisko srodnih vrsta (Sang i sar., 1995), a naročito u slučajevima kada se dve ili više vrsta javljaju simpatrički. U mnogim slučajevima kada je došlo do retikulatne evolucije utvrđeni su različiti nivoi ploidije unutar vrste ili roda (Guo et al., 2005, 2008; Ishikawa et al., 2009). Aneuploidija je odigrala važnu ulogu tokom evolucije roda Thymus, i ovaj fenomen je odgovoran za različite brojeve hromozoma čak i unutar iste vrste (Morales, 1997). Utvrđeni su različiti brojevi hromozoma kod svih vrsta koje su uključene u ovo ispitivanje, kod Th. pulegioides $2 \mathrm{n}=28,30$, kod Th. glabrescens $2 \mathrm{n}=28,32,52,56$ i 58, kod Th. pannonicus $2 \mathrm{n}=28$ i 35 i kod Th. praecox 2n=24, 28, 50, 54, 56 i 58 (Morales, 1997). Rezultati pokazuju da se podsekcije Alternantes i Pseudomarginati mogu smatrati dobrim podsekcijama. S druge strane, u podsekciji Isolepides, Th. glabrescens se jasno izdvaja od druge dve vrste iz ove podsekcije, iako su morfološki karakteri veoma slični onima kod Th. marschallianus. Između vrsta Th. marschallianus i Th. pannonicus, koje su takođe iz podsekcije Isolepides, genetička diferencijacija nije izražena, mada se morfološki značajno razlikuju. Slično je primećeno u zonama hibridizacije dve vrste roda Cardamine (Brassicaceae), gde je skorašnja studija pokazala da morfološki karakteri, 
posmatrani nezavisno, mogu da navedu na pogrešan zaključak o psmatranim genotipovima (Lihova et al., 2007). Slični rezultati su dobijeni i ispitivanjem mikrosatelitnih regiona kod hibrida Quercus coccifera L. i Quercus ilex L. (Ortego and Bonal, 2009), kao pri ispitivanju skorih hibridizacija u okviru Čileanskih vrsta roda Puya (Bromeliaceae) pomoću AFLP markera (Shulte et al., 2010). Ovi rezultati govore u prilog hipotezi o stalnom protoku gena između bliskih vrsta u sekciji Serpyllum roda Thymus. U slučajevima kada se dve, ili više vrsta javljaju simpatrički, ekološki faktori, kao na primer senovito i vlažnije stanište u odnosu na suvlje, otvoreno stanište, mogu da utiču na selekciju različitih morfoloških i fizioloških tipova (na primer: dlakavost jedinki i/ili postojanje različitih hemotipova), i na taj način ih stabilizuju, uprkos pretpostavljenom stalnom protoku gena (Schmidt-Lebuhn, 2007). Iz svega iznetog, može se smatrati neprikladnim da se sve ispitivane populacije svrstaju u svega dve ili tri vrste, jer bi se na taj način zanemarila ekološka i regionalna diferencijacija. Takođe, lošije bi se razumela morfološka, genetička i ekološka varijabilnost. Stoga je najuputnije da se na vrste roda Thymus primeni filogenetski koncept vrste, prema kojem vrste predstavljaju deo filogenije između dve tačke grananja. Drugim rečima, vrste bi bile najmanji agregat populacija, kod seksualne reprodukcije, ili linija, kod aseksualne reprodukcije, koje su, na osnovu stanja određenih karaktera razlikuju od drugih grupa date filogenije (semaforonti). Filogenetska definicija vrste je zasnovana na karakterima i orijentisana na obrasce (Nixon and Wheeler, 1990). Ovakva definicija dopušta genetičku razmenu sa drugim vrstama sve dok ova razmena ne sprečava nezavisni evolutivni razvoj ovih populacija (Luckow, 1995), što je izrazito istinit opis naročito za vrste podsekcije Isolepides.

\subsection{Opšta diskusija}

Ispitivane populacije vrsta roda Thymus pripadaju trima podsekcijama skcije Serpyllum, i njihovo grupisanje na osnovu fitohemijskih karaktera i molekularnih marker ne odgovara u potpunosti njihovom taksonomskom položaju.

Unutar Th. pulegioides (podsekcije Alternantes) jasno se uoačavaju dva hemotipa, geraniolni (P02, P05 i P09) i fenolni tip (P01, P03, P06 i P04). Po sastavu površinskih flavonoida, takođe, se mogu uočiti dve grupe vrsta. P02, P03, P04, P05 i 
P09 najzastupljeniji flavon je 5,6,-diOH-7,3',4'-triOMe, dok je drugi po zastupljenosti 5,6-diOH-7,8,3',4'-tetraOMe. Kod populacije P06, ova dva jedinjenja su u obrnutom odnosu, a kod populacije P01, je luteloin bio najzastupljenija komponenta. Analiza AFLP markera je, s druge strane, pokazala da sve populacije vrste Th. pulegioides formiraju jednu monofiletsku kladu sa visokom Bootstrap podrškom BS 94\%.

U podsekciji Isolepides, populacije vrste Th. glabrescens su jednoobrazne i po sastavu eetraskih ulja i po sastavu površinskih flavonoida. Naime, sve populacije se mogu okarakterisati kao fenolni hemotip, a najzastupljeniji površinski flavonoidi su 5,6,-diOH-7,3',4'-triOMe， 5,6-diOH-7,4'-diOMe (ladenein) i 5,6-diOH-7,8,3', 4'tetraOMe. Kod populacije P12 glavni površinski flavonoid je 5,6-diOH-7,8,4'-triOMe (pebrellin), koji je kod ostalih populacija prisutan ali ne u velikoj količini. Po sastavu etarskih ulja i površinskih flavonoida populacije Th. glabrescens su mnogo sličnije populacijama P01, P03, P06 i P04 vrste Th. pulegioides nego populacijama drugih vrsta iz podsekcije Isolepides, ali u Neighbour joining dendogramu dobijenom na osnovu AFLP podataka populacije Th. glabrescens se grupišu se u monofiletsku kladu sa Bootstrap podrškom od 93\%. Populacije druge dve vrste podsekcije Isolepides, Th. marschallianus i Th. pannonicus, izuzetno su heterogene i po sastavu etarskih ulja i po sastavu površinskih flavonoida. Sve populacije Th. marschallianus, P16, P17 i P18, imaju germakren-D kao glavnu komponentu etarskog ulja što je slučaj i sa populacijom P20 vrste Th. pannonicus, Populacije Th. marschallianus, P16, P17 i P18, i populacija Th. pannonicus P20 pripadaju istoj grupi i po sastavu površinskih flavonoida, s obzirom da je najzastupljeniji 5-OH-6,7,4'-triOMe (salvigenin) i 5-OH-6,7,8,4'-tetraOMe (gardenin B). Isti odnos površinskih flavonoida ima i populacija Th. pannonicus P19, kod koje ni jedan sastojak etarskog ulja nije dominantan, već $\alpha$-pinen, limonen i (E)- $\beta$ ocimen javljaju u sličnom procentu. Za etarsko ulje populacije Th. pannonicus P21 karakteristično je prisustvo linaloola $\mathrm{u}$ visokom procentu, dok su od površinskih flavonoida prisutni samo 5,6-diOH-7,8,4'-triOMe (pebrelin) i 5-OH-6,7,8,3',4'pentaOMe. Populacija Th. pannonicus P22se odlikuje visokim procentom E-kariofilena, a potom, i limonena u etarskom ulju, dok je su od površinskih flavonoida prisutni 5,4'diOH-6,7,8-triOMe (ksantomikrol) i 5-OH-6,7,8,4'-tetraOMe (gardenin B). Populacija Th. pannonicus $\mathbf{P 2 3}$ karakteristična je po izuzetno visokoj koncentraciji nerala i geraniala u etarskom ulju. Ovo je jedina populacija ove vrste koja ima srednju 
koncentraciju površinskih flavonoida i kod koje je 5,6,4'-triOH-7,8-diOMe (timusin) najznačajniji, a slede po značaju 5,6,4'-triOH-7,3'-diOMe i 5,6,-diOH-7,3',4'-triOMe. U etarskom ulju populacije Th. pannonicus P34 dominantna jedinjenja su mikren i $\alpha$ terpinel, dok je 5-OH-6,7,8,4'-tetraOMe (gardenin B) najznačajniji flavon, a 5,6-diOH7,8,4'-triOMe (pebrellin) drugi po značaju. Na Neighbour-joining stablu (Slika 3.4), klada koju formiraju jedinke koje pripadaju jedinke Th. marschallianus i Th. pannonicus nema bootstrap podršku veću od 50\% i jedinke ove dve vrste su međusobno izmešane. AMOVA pokazuje da je $\phi_{\text {ST }}$ vrednost između ove dve vrste veoma niska, što ukazuje da ove dve vrste međusobno nisu diferencirane.

Od ispitivanih populacija podsekcije Pseudomarginati, tri populacije vrste $T h$. balcanus, P24, P27 i P26, imaju visok sadržaj mikrena, linaloola i linalil acetata u etarskom ulju, dok su kod P25 u etarskom ulju najzastupljeniji neral, geranial i uz ova dva jedinjenja i neril acetat. $\mathrm{S}$ druge strane, kod sve četiri populacije Th. balcanus najznačajniji površinski flavonoid je5,6-diOH-7,8,4'-triOMe (pebrellin), a zatim 5,6diOH-7,8,3',4'-tetraOMe. Kod populacije Th. moesiacus P31, glavni sastojak etarskog ulja je $\alpha$-terpinil aceta, dok je od površinskih flavonoida najznačajniji je luteolin, s time što po prisustvu 5,6-diOH-7,8,4'-triOMe (pebrellin) i 5,6-diOH-7,8,3',4'-tetraOMe ova populacija je po flavonoidnom profilu slična populacijama Th. balcanus. U etarskom ulju populacije Th. praecox $\mathbf{P 3 2}$ najveću koncentraciju imaju $(E)$-kariofilen i $\gamma$-kadinen. Količina površinskih flavonoida je niska i prisutni su 5-OH-6,7,4'-triOMe (salvigenin) i 5-OH-6,7,8,4'-tetraOMe (gardenin B). Jedinke sve tri vrste iz ove podsekcije, koje su uključene $\mathrm{u}$ ispitivanje AFLP markera, formiraju monofiletsku kladu, koja ipak nije podržana visokom bootstrap vrednošću, dok s druge strane, na nivou vrste, Th. balcanus, Th. praecox i Th. moesiacus dobro podržani.

Sastav etarskih ulja ispitivanih populacija je izuzetno raznovrstan tako da ne daje sliku o filogenetskim odnosim među ispitivanim populacijama. Satatistička analiza sastava etarskih ulja za interperetaciju različitih odnosa među lekovitim i aromatičnim biljkama se pokazala u nekim slučajevima izuzetno prikladnom, kao na primer za karakterizaciju dve podvrste vrste Cistus creticus L. (Paolini i sar., 2009) ili populacija Helichrysum italicum (Roth) G. ssp. italicum (Morone-Fortunato i sar., 2010). S druge strane, kod ispitivanja gajenih sorti Ocimum basilicum L. poređenjem sastava etarskih ulja i AFLP markera, utvrđeno je da genetička sličnost ili različitost ne odražava 
obavezno sličnost ili različitost karaktera kao što je sastav etarskog ulja (Labra i sar., 2004). Trinidade i sar. (2008) su ispitujući genetički diverzitet, pomoću RAPD markera, kao i hemijski polimorfizam kod populacija Thymus caespititius sa ostrva Pico, São Jorge i Terceira, koja pripadaju Azorskom arhipelagu, dobili raziličito grupisanje populacija na osnovu ovih karaktera. Kod pet vrsta roda Thymus iz južne Italije, takođe je analiziran sastav etarskih ulja, međutim hemotipovi nisu korespondirali sa taksonomskom pripadnošću (De Lisi i sar., 2011), što je slučaj i sa vrstama iz Srbije. 


\section{Zaključci}

1. Na osnovu ispitivanja sastava etarskih ulja, površinskih flavonoida i analize AFLP markera izabranih populacija vrsta iz sekcije Serpyllum roda Thymus može se zaključiti da među vrstama ove sekcije postoji visoki stepen genetičke kompatibilnosti, da ne postoji čvrsta reproduktivna barijera između vrsta, te postoji mogućnost hibridizacije ukoliko jedna ili više vrsta žive simpatrički. Ipak, na osnovu rezultata može se konstatovati da populaciona struktura postoji i da su, sa izuzetkom Th. pannonicus i Th. marschallianus, sve ispitivane vrste dobre vrste.

2. Vrsta Th. pulegioides, koja je jedina ispitivana vrsta iz podsekcije Alternantes, pokazala se kao dobra vrsta po svim ispitivanim kriterijumima. U okviru populacija ove vrste utvrđeno je postojanje samo dva hemotipa, fenolnog i geraniolnog. Mada je postojanje hemotipova poznato kod vrsta iz roda Thymus, pa se često i u istoj populaciji nalaze dva, a nekada i više hemotipova, ova hemijska uniformnost se može smatrati odrazom genetičke koherentnosti. Takođe, sve ispitivane populacije ove vrste pripadaju istom flavonoidnom profilu. Kod svih populacija su utvrđene niske i srednje količine flavonoida, kao i 5,6-diOH-7-OMe i 5,6-diOH-7,8-diOMe supstitucione šeme u A prstenu. Molekularni markeri, tj. AFLP analiza, podržavaju zaključak da je Th. pulegioides dobra vrsta. Naime, sve ispitivane jedinke vrste Th. pulegioides formiraju posebanu kladu koja ima visoku bootstrap podrušku i ujedno cela ova grupa je najviše divergirala od ostalih vrsta koje su uključene u ova istraživanja.

3. U okviru podsekcije Isolepides, vrsta Th. glabrescens se jasno izdvaja od druge dve vrste ove podsekcije. Sve populacije Th. glabrescens po sastavu etarskih ulja pripadaju fenolnom hemotipu, s obzirom da su kod svih populacija utvrđene visoke koncentracije $p$-cimena, $\gamma$-terpinena i timola. Po sadržaju površinskih flavonoida sve ispitivane populacije pripadaju istoj grupi, sa niskim i srednjim količnama flavonoida i 5,6-diOH-7-OMe i 5,6-diOH-7,8-diOMe supstitucionim šemama u A prstenu. AFLP markeri, takođe, navode na zaključak da je $T h$. 
glabrescens dobra vrsta, pošto sve ispitivane jedinke ove vrste formiraju posebnu kladu sa visokom bootstrap podrškom.

4. Vrsta Th. marschallianus, iz podsekcije Isolepides, je po sastavu etarskih ulja ispitivanih populacija, veoma jednoobrazna, pošto sve ispitivane populacije imaju kao najzastupljeniju komponentu germakren-D. Po sadržaju površinskih flavonoida sve ispitivane populacije pripadaju istoj grupi, sa niskim količinama flavonoida i 5-OH-6,7-diOMe i 5-OH-6,7,8-triOMe supstitucionim šemama u A prstenu. AFLP markeri, međutim, ne izdvajaju ispitivane jedinke ove vrste $u$ jednu kladu, već formiraju zajedničku kladu sa jedinkama vrste Th. pannonicus. U ovoj kladi jedinke ove dve vrste su izmešane i klada ima bootstrap podršku ispod 50\%.

5. Podsekciji Isolepides pripada i vrsta Th. pannonicus. Ova vrsta je po sastavu etarskih ulja najheterogenija od svih ispitivanih taksona ovog roda. Svaka od ispitivanih populacija ima svoj hemotip. Po sadržaju površinskih flavonoida populacije ove vrste se razlikuju kako po količinama, tako i po tipovima supstitucije u A prstenu. Kod dve populacije prisutna je 5-OH-6,7-diOMe i 5OH-6,7,8-triOMe supstituciona šema u A prstenu, kod jedne 5,6-diOH-7-OMe i 5,6-diOH-7,8-diOMe, kod jedne 5,6-diOH-7,8-diOMe i 5-OH-6,7,8-triOMe, a kod preostale dve populacije količine površinskih flavonoida su male. Analizom AFLP markera, jedinke ispitivanih populacija su pomešane u zajedničkoj kladi sa jedinkama Th. marschallianus.

6. Rrezultati ispitivanja, i fitohemijskih i molekularnih markera, navode na zaključak da je podsekcija Isolepides polifiletska. Prema našim rezultatima, Th. glabrescens je dobra vrsta, dok ne postoji dovoljna genetička diferencijacija između populacija Th. pannonicus i Th. marschallianus. U slučaju ove dve vrste, a imajući u vidu jasne morfološke razlike, prikladno bi bilo primeniti filogenetski koncept vrste.

7. Iz podsekcije Pseudomarginati ispitivane su populacije vrsta Th. balcanus, Th. moesiacus i Th. praecox. Kod tri ispitivane populacije Th. balcanus, glavne komponente etarskih ulja su linalil acetat, linalool i mircen, dok su kod jedne geranial i neral. Kod ispitivane populacije Th. moesiacus najzastupljenija komponenta etarskog ulja bio je $\alpha$-terpinil acetat, a kod Th. praecox glavna 
komponenta etarskog ulja je (E)-kariofilen. Kod ispitivanih vrsta iz ove podsekcije količina površinskih flavonoida je mala ili samo u tragovima. Kod sve četiri populacije Th. balcanus i populacije Th. moesiacus najzastupljeniji je bio pebrellin, a značajan je još bio i 5,6-diOH-7,8,3',4'-tetraOMe. Ispitivana populacija Th. praecox pripada drugom flavonoidnom profilu, posto su prisutni salvigenin i gardenin B, kao i metoksilovani flavanoni. Molekularni markeri grupišu sve jedinke iz ove podsekcije u monofiletsku kladu, koja ima nisku bootstrap podršku. Na nivou vrste, Th. balcanus, Th. praecox i Th. moesiacus dobro podržani. Svi ovi rezultati navode na zaključak da je podsekcija Pseudomarginati monofiletska, a ispitivane vrste mogu se smatrati dobrim vrstama.

8. Rezultati i fitohemijskih i molekularnih ispitivanja pokazuju da su, sa izuzetkom Th. marschallianus i Th. pannonicus, dobro genetički diferencirane vrste. U budućim ispitivanjima vrste Th. pulegioides treba uključiti populacije sa većeg prostora, s obzirom da ova vrsta ima veoma širok areal, kao i populacije drugih vrsta iz podsekcije Alternantes, kao na primer Th. alpestris i Th. comosus.

9. Kod podsekcije Isolepides, Th. glabrescens je dobro diferencirana vrsta I, da bi se to potvrdilo u daljim istraživanjima, treba uključiti veći broj populacija sa šireg prostora. Imajući u vidu da se Th. marschallianus i Th. pannonicus genetički nedovoljno razlikuju, za dobijanje jasnije slike odnosa ove dve vrste, $u$ istraživanja treba uključiti veći broj populacija, naročito onih koje su geografski udaljenije. Takođe, trebalo bi primeniti još neke molekulane tehnike prikladne za ispitivanja populacione varijabilnosti, kao što su mikrosateliti.

10. Da bi se dobila jasnija slika o najverovatnije monofiletskom poreklu podsekcije Pseudomarginati kao i potvrda o odgovarajućem shvatanju okvira vrsta, u daljim ispitivanjima treba uključiti veći broj vrsta i populacija, uz primenu drugih molekularnih markera..

11. Na osnovu rezultata istraživanja, može se zaključiti da su hemotaksonomski i molekularni pristup i na ovom modelu pokazali značajnu kompatibilnost. To ukazuje na potrebu proučavanja ciljnih taksona sa hemotaksonomskog, molekularnog, kao i drugih aspekata u rešavanju filogenetskih odnosa i njihovog taksonomskog statusa. Kombinovanje pristupa je posebno važno u slučajevima 
kada se radi o grupama čiji su predstavnici morfološki veoma varijabilni i nedovoljno diferencirani, kao što su taksoni iz sekcije Serpyllum, kao i iz drugih sekcija izuzetno kompleksnog roda Thymus. Jedino takav sveobuhvatan pristup može da pruži pouzdaniju sliku o evoluciji i filogenetskim odnosima unutar istraživane srodničke grupe biljaka. 


\section{Literatura}

Abad, M.J., Bermejo, P., Villar, A., Sanchez Palomino, S.S., Carrasco, L. (1997). Antiviralactivity of medicinal plant extracts. Phytother. Res. 11: 198-202.

Adams, R. P. (2001). Identification of Essential Oil Components by Gas Chromatography / Quadrupole Mass Spectroscopy. Allured Publishing Corporation: Illinois.

Adzet, T., Granger, R., Passet, J., San Martin, R. (1977a). Le polymorphisme chimique dans le genre Thymus: ca signification taxonomique. Biochem. Syst. Ecol. 5: 269-72.

Adzet, T., Granger, R., Passet, J., San Martin, R. (1977b) Chimiotypes de Thymus mastichina L. Plant. Méd. Phytothér. 11: 275-280.

Ausloos, P., Clifton, C., Lias, S. G., Shamim, A., Stein, S. (1992). NIST/EPA/NIH Mass Spectral Database, v. 4.0; U.S. Department of Commerce: Gaitherburg, MD.

Barberán, F.A.T. (1986). The flavonoid compounds from the Labiatae. Fitoterapia 57: 67-95.

Barberán, F.A.T., Hernándes, L., Tonás, F. (1986). Chmotaxonmic study of flavonoids in Thymbra capitata. Phytochemistry 25 (2): 561-562.

Barberán, F.A.T., Nunez, J.M., Tomas F. (1985). An HPLC study of flavones from some Spanish Sideritis species. Phytochemistry 24: 1285-1288.

Beardsley, P.M., Yen, A., Olmstead, R.G., (2003). AFLP phylogeny of Mimulus section Erythranthe and the evolution of Hummingbird pollination. Evolution 57: 1397-1410.

Bellino, A., Venturella, P., Marcenó, C. (1980). Naringenin and neopocirin from Micromeria species and Calamintha nepeta. Fitoterapia 51: 163-165. 
Bentham, G. (1834). Lab. Gen. Sp.: Thymus, London.

Bentham, G. (1876). Labiatae. In G. Bentham, J. D. Hooker ed(s). Genera plantarum, vol. 2, London: Reeve \& Co. Pp. 1160-1223.

Blázquez, M.A., Zafra-Polo, M.C., Villar, A. (1989) The volatile oil of Thymus leptophyllus growing in Spain. Planta Med., 55: 198.

Boissier, E. (1839-1845). Voyage botanique dans le Midi de I'Espagne, Paris.

Brauchler, C., Meimberg, H., Heubl, G. (2010). Molecular phylogeny of Menthinae (Lamiaceae, Nepetoideae, Mentheae) - Taxonomy, biogeography and conflicts. Mol. Phylogenet. and Evol. 55: 501-523.

Brauchler, C., Meimberg, H., Abele, T., Heubl, G. (2005). Polyphyly of the genus Micromeria (Lamiaceae) - evidence from cpDNA sequence data. Taxon 54: 639650.

Briquet, J. (1897). Labiatae. In A. Engler and K. Prantl (eds), Die Nutilrlichen Pflanzenfdmilien IV 36 (a), Leipzig.

Brotero, F. A. (1804). Flora Lwitanica, Lisbon.

Bryant, J.P., Provenza, F.D., Pastor, J., Reichardt, P.B., Clausen, T.P., Toit (du), J.T. (1991). Interactions between woody plants and browsing mammals mediated by secondary metabolites. Annu. Rev. Ecol. Syst. 22: 431-446.

Bucar, F., Males, Z., Plazibat, M. (2005). Essential oil of Thymus bracteosus Vis. ex Benth., an Endemic Species of Dinaric Karst. J. Essent. oil Res.17 (4): 457-458.

Bunsawat, J., Elliott, N.E., Hertweck, K.L., Sproles, E., Alice, L.A., (2004). Phylogenetics of Mentha (Lamiaceae): evidence from chloroplast DNA sequences. Syst. Bot. 29: 959-964.

Burzanska-Hermann, Z. (1978). Isolation and identification of components of the flavonoid fraction of native Mentha herbs. Acta Pol. Pharm. 35 (6): 673-680. 
Cabo, J., Cabo, M.M., Crespo, M.E., Jiménez, J., Navarro, C. (1986a). Thymus granatensis Boiss.: II. Etude de son cycle evolutif. Plant. Méd. Phytothh. 20: 129134.

Cabo, J., Cabo, M.M., Crespo, M.E., JimCnez, J. and Navarro, C. (1986b). Thymus granatensis Boiss.: I. Etude qualitative et quantitative de son huile essentielle. Plant. Méd. Phytothh. 20: 18-24.

Cabo, J., Crespo, M.E., Jiménez, J., Navarro, C., Risco, S. (1987). Seasonal variation of essential oil yield and composition of Thymus hyemalis. Planta Med. 53: 380-383.

Çadirci, E., Süleyman, H., Gürbüz, P., Kuruüzüm Uz, A., Güvenalp, Z., Demirezer, L. O. (2012). Anti-inflammatory effects of different extracts from three Salvia species. Turk. J. Biol. 36: 59-64.

Cantino, P.D., Harley, R.M., Wagstaff, S.J. (1992). Genera of Labiatae: Status and Classification. In R.M. Harley \& T. Reynolds (editors.). Advances in Labiate Science: 511-522 (1992).

Cantino, P.D., Sanders, R.W. (1986). Subfamilial classification of Labiatae. Syst. Bot. 11: 163-85.

Carović-Stanko, K., Liber, Z., Politeo, O., Strikić, F., Kolak, I., Milos, M., Kolak, I., Satovic, Z. (2011). Molecular and chemical characterization of the most widespread Ocimum species. Plant. Syst. Evol. 294: 253-262.

Chase, M.W., Soltis, D.E., Olmstead, R.G., Morgan, D., Mishler, B.D., Duvall, M.R., Price, R.A., Hills, H.G., Qiu, Y.-L, Kron, K.A., Rettig, J.H., Conti, E., Palmer, J.D., Manhart, J.R., Sytsma, K.J., Michaels, H.J., Kress, W.J., Karol, K.G., Clark, W.D., Hedren, M., Gaut, B.S., Jansen, R.K., Kim, K.-J., Wimpee, C.F., Smith, J.F., Furnier, G.R., Strauss, S.H., Xiang, Q.-Y., Plunkett, G.M., Soltis, P.S., Swensen, S.M., Williams, S.E., Gadek, P.A., Quinn, C.J., Eguiarte, L.E., Les, D.H., Golenberg, E., Learn, G.H.J., Graham, S.W., Barrett, S.C.H., Dayanandan, S., Albert, V.A., (1993). Phylogenetics of seed plants: an analysis of nucleotide 
sequences from the plastid gene $r b c \mathrm{~L}$. Ann. Missouri Botanical Garden 80: 528580.

Corticchiato, M., Bernardini, A., Costa, J., Bayet, C., Saunois, A., Voirin, B. (1995). Free flavonoid aglycones from Thymus herba-barona and its monoterpenoid chemotypes. Phytochemistry 40: 115-120.

Corticchiato, M., Tomi, F., Bernardini, A.F., Casanova, J. (1998). Composition and infraspecific variability of essential oil from Thymus herba-barona Lois. Biochem. Syst. Ecol. 26: 915-932.

Čajkanović, V. (1985). Rečnik srpskih narodnih verovanja o biljkama. SANU, SKZ, Beograd, 1985.

Dajic Stevanovic, Z., Sostaric, I. (2006). Review of some useful methods in taxonomical interpretation of difficult taxa of medicinal and aromatic plants. Case: Thymus L. Proceedings of the $4^{\text {th }}$ Conference on Medicinal and Aromatic Plants of South-East European Countries, 28-31 May, Iasi, Romania: 63-71.

Dajic Stevanovic, Z., Sostaric, I., Marin, P.D., Stojanovic, D., Ristic, M. (2008). Population variability in Thymus glabrescens Willd. from Serbia: morphology, anatomy and essential oil composition. Arch. Biol. Sci., Belgrade, 60 (3): 475-483.

De Lisi, A., Tedone, L., Montesano, V., Sarli, G., Negro, D. (2011). Chemical characterisation of Thymus populations belonging from Southern Italy. Food Chemistry 125: 1284-1286.

Després, L., Gielly, L., Redoutet, B., Taberlet, P. (2003). Using AFLP to resolve phylogenetic relationshipsin a morphologically diversified plant species complex when nuclear and chloroplast sequences fail to reveal variability. Molecular Phylogenetics and Evolution 27: 185-196.

Didry, N., Dubreuil L., Pinkas, M. (1994). Activity of thymol, carvacrol, cinnamaldehyde and eugenol on oral bacteria, Pharm. Acta Helv. 69: 25-28. 
Didry, N., Dubreuil, L., Pinkas, M. (1993). Antibacterial activity of thymol, carvacrol and cinnamaldehyde alone or in combination. Pharmazie. 48: 301-304.

Diklić, N., 1974. Thymus L. In: Josifović, M. (Ed.), Flora R. Srbije, SANU, Belgrade, pp. 475-509.

Dixon, C. J., Schönswetter, P., Suda, J., Wiedermann, M. M., Schneeweiss, G. M. (2009). Reciprocal Pleistocene origin and postglacial range formation of an allopolyploid and its sympatric ancestors (Androsace adfinis group, Primulaceae). Mol. Phyl. Evol. 50: 74-83.

Dodd, R. S., Kashani, N. (2003). Molecular differentiation and diversity among the California red oaks (Fagaceae; Quercus section Lobatae). Theoretical and Applied Genetics 107: $884-892$.

Dorman, H.J., Deans, S.G. (2000). Antimicrobial agents from plants: antibacterial activity of plant volatile oils. J. Appl. Microbiol. 88: 308-316.

Echeverrigaray, S., Agostini, G., Atti-Serfini, L., Paroul, N., Pauletti, G.F., Atti dos Santos, A.C. (2001). Correlation between the chemical and genetic relationships among commercial thyme cultivars. J. Agric. Food Chem. 49: 4220-4223.

Edwards, C., Soltis, D.E., Soltis, P.S. (2006). Molecular phylogeny of Conradina and other shrub mints (Lamiaceae) from the southeastern USA: evidence for Hybridization in Pleistocene refugia? Syst. Bot. 31: 193-207.

Edwards, C.E., Lefkowitz, D., Soltis, D.E., Soltis, P.S. (2008a). Phylogeny of Conradina, related southeastern scrub mints (Lamiaceae) based on GapC genesequences. Int. J. Plant Sci 169 (4): 579-594.

Edwards, C.E., Soltis, D.E., Soltis, P.S., (2008b). Using patterns of genetic structure based on microsatellite loci to distinguish between hybridization and incomplete lineage sorting in Conradina. Mol. Ecol. 17: 5157-5174.

Elena-Rossell, J.A. (1976). Projet d'une etude de tuxonomie exphimentale du genre Thymus. Doctoral thesis, Montpellier. 
Erdtman, G. (1945). Pollen morphology and plant taxonomy. IV. Labiatae, Verbenaceae, and Avicenniaceae. Svensk Bot. Tidskr. 39:279-285.

Evanno, G., Regnaut, S., Goudet, J., (2005). Detecting the number of clusters of individuals using the software STRUCTURE: a simulation study. Molecular Ecology 14, 2611-2620.

Excoffier, L., Smouse, P.E., Quattro, J.M., (1992). Analysis of molecular variance inferred from metric distances among DNA haplotypes: application to human mitochondrial DNA restriction data. Genetics 131, 479-491.

Fadli, M., Saada, A., Sayadib, S., Chevalierc, J., Mezriouia, N. E., Pagèsc, J. M., Hassani, L. (2012). Antibacterial activity of Thymus maroccanus and Thymus broussonetii essential oils against nosocomial infection - bacteria and their synergistic potential with antibiotics. Phytomedicine 19: 464-471.

Fan, C., Qiu-Yun Xiang, J. (2003). Phylogenetic analyses of Cornales based on 26S rDNA and combined 26S rDNA-matK-rbcL sequence data. American Journal of Botany 90: 1357-1372.

Felsenstein, J. (1985). Confidence limits on phylogenies: An approach using the bootstrap. Evolution 39:783-791.

Fernandes, R, Heywood, V.H. (1972) In: Flora Europaea Vol. 3. Tutin T.G., Heywood V.H., Burges N.A., Moore D.M., Valentine D.H., Walters S.M., et al. (eds.) Cambridge University Press, Cambridge.

Ferreres, F., Barberán, F.A.T., Tomas, F. (1985). 5,6,4'-trihidroxy-7,8dimethoxyflavone from Thymus membranaceus. Phitochemistry 24 (8): 1869-1871.

Ferreres, F., Tomás-Lorente, F., Tomás-Barberán, F.A. (1989). Biochemical Identification of Sideritis serrata $x$ S. bourgaeana hybrids by HPLC analyses of flavonoids. Z. Naturforsch 44c: 568-572. 
García Martín, D. and García Vallejo, M.C. (1983). Chemotypes of Thymus zygis (Lofl.) L. of Guadarramma Sierra and other places in Castile (Spain). 9th International Essential Oil Congress, Singapore 1983: 134-140.

García Vallejo, M.C., Garcia Martín, D., Muñoz, F. (1984). Avance de un estudio sobre las esencias de Thymus mastichina L. español ("Mejorana de españa"). An. Inst. Nac. Inv. Agr. (Madrid), Ser. Forestal, 8: 201-218.

Goldblatt, P., Savolainen, V., Porteous, O., Sostaric, I., Powell, M., Reeves, G., Manning, J.C., Barraclough, T.G., Chase, M.W. (2002). Radiation in the Cape flora and the phylogeny of peacock irises Moraea (Iridaceae) based on four plastid DNA regions. Molec. Phylogenet. Evol. 25. (2): 241-360.

Gonçalves, M.J., Cruzb, M.T., Cavaleiroa, C., Lopesb, M.C., Salgueiro, L. (2010). Chemical, antifungal and cytotoxic evaluation of the essential oil of Thymus zygis subsp. sylvestris. Industrial Crops and Products 32: 70-75.

Gouyon, P.H., Vernet, P., Guillerm, J.L., Valdeyron, G. (1986). Polymorphisms and environment: the adaptive value of the oil polymorphism in Thymus vulgaris L. Heredity, 57: 59-66.

Granger, R, Passet, J. (1973). Thymus vulgaris spontane de France: races chimiques et chemotaxonomie. Phytochemistry 12. (7): 1683-1691

Granger, R., Passet, J., Teulade-Arbousset, G. (1963). Diversite des essences de Thymus vulgarir L. La France et ses Parfums, 6: 225-230.

Grayer-Barkmeijer, R.J., (1978). Flavonoids in Parahebe and Veronica: a chemotaxonomic study. Biochem. Syst. Ecol. 6, 131-137.

Grayer, R.J., Veitch, N.C., Kite, G.C., Price, A.M., Kokubun, T. (2001). Distribution of 8-oxygenated leaf-surface flavones in the genus Ocimum. Phytochemistry 56: 559-567.

Greger, H. (1978). Comparative phytochemistry and systematics of Anacyclus. Biochem. Syst. Ecol. 6. (1): 11-17. 
Grujić Jovanović, S., Marin, P.D., Dzamić, A., Ristić, M. (2009). Essential oil composition of Thymus longicaulis from Serbia. Chemistry of Natural Compounds 45 (2): 265-266.

Guerin, G.R. (2005). Nutlet morphology in Hemigenia R.Br. and Microcorys R.Br. (Lamiaceae). Pl. Syst. Evol. 254: 49-68.

Gurni, A.A., Kubitzki, K. (1981). Flavonoid chemistry and systematics of the Dilleniaceae. Biochem. Syst. Ecol. 9: 109-114.

Guo, Y.-P., Saukel, J., Mittermayr, R., Ehrendorfer, F. (2005). AFLP analyses demonstrate genetic divergence, hybridization, and multiple polyploidization in the evolution of Achillea (Asteraceae-Anthemideae). New Phytologist 166: 273-290.

Guo, Y.-P., Saukel, J., Ehrendorfer, F. (2008). AFLP Trees versus scatterplots: evolution and phylogeography of the polyploidy complex Achillea millefolium agg. (Asteraceae). Taxon 57 (1): 153-169.

Hammer, Ø., Harper, D.A.T., Ryan P.D. (2001). PAST: paleontological statistics software package for education and data analysis. Palaeontolo Electron 4(1): 9.

Harborne, J.B. (1967). Comparative biochemistry of the flavonoids. Academic Press, London and New York.

Harborne, J.B. (1975). Biochemical systematic of flavonoids. In: Harborne, J.B., Marby, T,J., Mabry, H. (EdS), The Flavonoids. Chapman and Hall, London. 10561095.

Harborne, J.B. (1977). Variation in pigment patterns in Pyrrhopappus and related taxa of the Cichorieae. Phytochemistry 16: 927-928.

Harborne, J.B. (1984). Plant Chemosystematics. Academic Press, London.

Harborne, J.B., Boardley, M. (1985). The widespread occurrence zwitterions in nature of anthocyanins as zwitterions. Z. Naturfrosch. C. 40: 305-308 
Harborne, J.B., Tomas-Barberan, F.A., Williams, C.A., Gil, M.I. (1986). A chemotaxonomic study of flavonoids from European Teucrium species. Phytochemistry. 25. 2811-16.

Hare, J.D., (2002). Geographic and genetic variation in the leaf surface resin components of Mimulus aurantiacus from southern California. Biochem. Syst. Ecol. 30, 281-296.

Harley, R.M., Atkins, S., Budanstev, A.L., Cantino, .PD., Conn, B.J., Grayer, R., Harley, M.M. (2004). Labiatae. In: Kubitzki, K. (Ed.), The Families and Genera of Vascular Plants VII. Springer, Berlin/Heidelberg.

Hartvig, P. (1987). A taxonomical revision of Thymus sect. Teucrioides (Lamiaceae). Pl. Syst. Evol. 155: 197-213.

Hernándes, L.M., Tomás-Barberán, F.A., Tomás-Lorente, F. (1987). A chemotaxnomic study of free flavone aglicons from some Iberian Thymus species. Biochem. Syst. Ecol. 15 (1): 61-76.

Hörhamer, L., Wsagner, H. (1962). In: Gore, T.S. (EdS), Chemistry of Natural and Synthetic Colour Markers. Academic Press, London: 315.

Horváth, G., Kocsis, B., Botz, L., Németh, J., Szabó, L.Gy. (2002). Antibacterial activity of Thymus phenols by direct bioautography. Acta Biol. Szeged. 46: 145146.

Horwath, A.B., Grayer, R.J., Keith-Lucas, M.D., Simmonds, M.S.J., (2008). Chemical characterisation of wild populations of Thymus from different climatic regions in southeast Spain. Biochemical Systematics and Ecology 36, 117-133.

Huff, D.R., (1997). RAPD characterization of heterogeneous perennial ryegrass cultivars. Crop Sci. 37, 557-594.

Huguet del Villar, E. (1934). Quelques Thymus du Sud-est Ibérique. Cavanillesia, 6: 104-125. 
Husain, S.Z., Heywood, V.H., Markham, K.R. (1982). Distribution of flavonoids as chemotaxonomic markers in the genus Origanum L. and related genera in Labiatae. In: Margaris, N,, Koedam, A., Vokou, D. ed(s). Aromatic plants: basic and applied aspects. Martinus Nijhoff, The Hague, Boston, London. 141-52.

Ietswaart, J.H. (1980). A taxonomic revision of the genus Origanum (Labiatae). The Hague, Boston, London Leiden University Press.

Ishikawa, N., Yokoyama, J., Tsukaya, H. (2009). Molecular evidence of reticulate evolution in the subgenus Plantago (Plantaginaceae). Am. J. Bot. 96 (9): 16271635.

Jalas, J . (1982) Thymus. In K.H. Rechinger (ed.), Flora Iranica. Graz. 532-551.

Jalas, J. (1971). Notes on Thymus L. (Labiatae) in Europe. I. Supraspecific classification and nomenclature. Bot. J. Linn. Soc. 64(2): 199-215.

Jalas, J. (1972). Thymus L. In: Flora Europaea Vol. 3. Tutin T.G., Heywood V.H., Burges N.A., Moore D.M., Valentine D.H., Walters S.M., et al. (eds.) Cambridge University Press, Cambridge. pp. 172-182.

Jalas, J. (1973). Thymus subsect. Pseudomarginati in the Himalayas and adjoining western mountain ranges, and in Caucasia. Ann. Bot. Fennici 10: 104-122.

Jalas, J. (1982) Thymus. In P.H. Davis (ed.), Flora of Turkey and the East Aegean Islands, Vol. 7, Edinburgh, pp. 349-382.

Jamzad, Z, Chase, W.M., Ingrouille, M., Simmonds, M.S.J., Jalili, A., (2003). Phylogenetic relationships in Nepeta L. (Lamiaceae) and related genera based on ITS sequence data. Taxon 52: 21-32.

Jullien, F., Voirin, B., Bermillon, J., Favre-Bonvin, J. (1984). Highly oxygenated flavones from Mentha piperita. Phytochemistry 23: 2972. 
Karuza-Stojaković, L., Pavlović, S., Živanović, P., Todorović, B. (1989). Composition and yield of essential oils of various species of the genus Thymus L. Arh. Farm. 39: 105-111.

Kaul, T.N., Middleton, E. Jr, Ogra, P.L. (1985). Antiviral effect of flavonoids on human viruses. J. Med. Virol.: 15, 71-79.

Kaya, A., Dirmenci, T. (2008). Nutlet Surface Micromorphology of the Genus Nepeta L. (Lamiaceae) in Turkey. Turk. J. Bot 32: 103-112.

Kelleher, C. T., Hodkinson, T. R., Douglas, G. C., Kelly, D. L. (2005). Species distinction in Irish populations of Quercus petraea and Q. robur : Morphological versus molecular analyses. Ann. Bot. 96 (7): 1237 - 1246 .

Kizil, S., Uyart, F. (2006). Antimicrobial activities of some Thyme (Thymus, Staureja, Origanum and Thymbra) species against important plant pathogens. Asian J. Chem. 18: 1455-1461.

Kulevanova, S., Ristic, M., Stafilov, T. (1995). The composition of the essential oils from Thymus macedonicus (Degen et Urumov) Ronn. subsp. macedonicus and Thymus tosevii Velen. subsp. tosevii growing in Macedonia. Farmacija, 43: 13-14.

Kulevanova, S., Ristic, M., Stafilof, T. (1996a). Comparative essential oils study of Thymus longidens Velen. var. lanicaulis Ronn. and Thymus longidens var. dassareticus Ronn. Bolletino Chimico Farmaceutico, 135: 239-243.

Kulevanova, S., Ristic, M., Stafilov, T. (1996b). Composition of the essential oil from Thymus moesiacus from Macedonia. Planta Med., 62: 78-79.

Kulevanova, S., Ristic, M., Stafilov, T., Dorevski, K. (1996c). Essential oil composition of Thymus tosevii ssp. tosevii var. longifrons. Acta Pharm. (Zagreb), 46, 303-308.

Kulevanova, S., Ristic, M., Stafilov, T., Dorevski, K. and Ristov, T. (1997). Composition of essential oils of Thymus tosevii ssp. tosevii and Thymus tosevii ssp. substriatus from Macedonia. Pharmazie, 52: 382-386. 
Kulevanova, S., Ristic, M., Stafilov, T., Matevski, V. (1998a). Composition of the essential oils of Thymus jankae Chel. var. jankae, T. jankae var. pantotrichw Ronn. and T. jankae var. patentipilus Lyka from Macedonia. J. Essent. Oil Res., 10, 191194.

Kulevanova, S., Ristic, M., Stafilov, T., Matevski (1998b). Composition of the essential oil of Thymus rohlenae Velen. from Macedonia. J. Essent. Oil Res., 10, 537-538.

Kulevanova, S., Ristic, M., Stafilov, T., Matevski (1998c). Composition of the essential oil of Thymus albanus ssp. albanus H. Braun from Macedonia. J. Essent. Oil Res., 10: 335-336.

Kulevanova, S., Ristic, M., Stafilov, T. (1999). Composition of the essential oil of Thymus macedonicus subsp. macedonicus (Degen et Urum.) Ronn. from Macedonia. Herba Pol., 45: 80-86.

Kuštrak, D., Martinis, Z., Kuftinec, J., Blazevic, N. (1990). Composition of the essential oils of some Thymus and Thymbra species. Flavour Fragr. J., 5: 227-231.

Kuzoff, R. K., Sweere, J. A., Soltis, D. E., Soltis, P. S., Zimmer, E. A. (1998). The phylogenetic potential of entire 26S rDNA sequences in plant. Molecular Biology Evolution 15: 251-263.

Labra, M., Miele, M., Ledda, B., Grassi, F., Mazzei, M., Sala, F. (2004). Morphological characterization, essential oil composition and DNA genotyping of Ocimum basilicum L. cultivars. Plant Science 167: 725-731.

Lewontin, R.C., (1972). The apportionment of human diversity. In: Dobzhansky, T., Hecht, M.K, Steere, W.C. (Eds), Evolutionary Biology 6. Appleton-Century-Crofts, New York, pp. 381-398.

Lihova, J., Kučera, J., Perny, M., Marhold, K., (2007). Hybridization between two polyploid Cardamine (Brassicaceae) species in northwestern Spain: discordance between morphological and genetic variation patterns. Ann. Bot. 99 (6): 1083-1096. 
López, V., Akerreta, S., Casanova, E., García-Mina, J. M., Cavero, R. Y., Calvo, M. I. (2007). In Vitro Antioxidant and Anti-rhizopus Activities of Lamiaceae Herbal Extracts. Plant Foods Hum. Nutr. 62:151-155.

Ložienė, K., Vaičiunienė, J., Venskutonis, P.R. (2003). Chemical composition of the essential oil of different varieties of thyme (Thymus pulegioides) growing wild in Lithuania. Biochem. Syst. Ecol. 31: 249-259.

Ložienè, K., Venskutonis, P.R., Šipailienè, A., Labokas, J. (2007). Radical scavenging and antibacterial properties of the extracts from different Thymus pulegioides L. chemotypes. Food Chemistry 103: 546-559.

Luckow, M. (1995). Species concepts: assumptions, methods, and applications. Syst. Bot. 20, 589-605.

Maksimović, Z., Milenković, M., Vučićević, D., Ristić M. (2008a). Chemical composition and antimicrobial activity of Thymus pannonicus All. (Lamiaceae) essential oil. Cent. Eur. J. Biol. 3: 149-154.

Maksimović, Z., Stojanović, D., Šoštarić, I., Dajić, Z., Ristić, M., (2008b). Composition and radical-scavenging activity of Thymus glabrescens Willd. (Lamiaceae) essential oil. Journal of the Science of Food and Agriculture 88 (11): 2036-2041.

Mamadalieva, N,Z, Herrmann, F,, El-Readi, M,Z, Tahrani, A,, Hamoud, R, Egamberdieva, D.R,, Azimova, S.S,, Wink, M. (2011). Flavonoids in Scutellaria immaculata and S. ramosissima (Lamiaceae) and their biological activity. J Pharm Pharmacol. 63(10): 1346-57.

Marin, P.D. (1989). A chemotaxonomical and micromorphological study of Micromeria Benth. and related genera from tribe Saturejeae (Lamiaceae). Unpublished Ph. D. thesis, University of Belgrade.

Marin, P.D. (1995). Diversity and Taxonomical significance of flavonoids in the Lamiaceae. Arch. Biol. Sci. Belgrade 47 (3-4): 101-109. 
Marin, P.D. (1996). Orašice i trihome u familiji Lamiaceae. Biološki fakultet, Beograd.

Marin, P.D. (2003). Biohemijska i molekularna sistematika biljaka. NNK Internacional, Beograd.

Marin, P.D., Grayer, R.J., Kite, G.C., Matevski, V. (2003). External leaf flavonoids of Thymus species from Macedonia. Biochem. Syst. Ecol. 31. (11), 1291-1307.

Marin, P.D., Grayer, R.J., Kite, G.C., Veljic, M. (2005). External flavones from Thymus striatus Vahl (Lamiaceae) (2005). Biochem. Syst. Ecol. 33 (11): 1179-1182.

Marin, M., Koko, V., Duletic-Laušević, S., Marin, P.D. (2008). Micromorphology of trichomes of Thymus malyi (Lamiaceae). Journal of Microscopy 232: 406 - 409

Marinova, E.M. and Yanishlieva, N.V. (1996). Antioxidative activity of phenolic acids on triacylglycerols and fatty acid methyl esters from olive oil. Food Chem. 56: $139-145$

Markham, K.R., Mabry, T..J, Swift, W.T. (1970). Distribution of flavonoids in the genus Baptisia (Leguminosae). Phytochemistry 9: 2359-2364.

Mártonfi, P. (1992). Essential oil content in Thymus alpestris pestris in Slovakia. Thaiszia, Kosice 2: 75-78.

Mártonfi, P. Greijtovsky, A., Repcak, M. (1994) Chemotype pattern differentiation of Thymus pulegioides on different substrates. Biochem. Syst. Ecol. 22: 819-825.

Mastelic, J., Grzunov, K., Kravar, A. (1992). The chemical composition of terpene alcohols and phenols from the essential oil and terpene glycosides isolated from Thymus pulegioides L. grown wild in Dalmatia. Riv. Ital. 3: 19-22.

Mayol, M., Rosselló, J.A., Mus, M., Morales, R. (1990). Thymus herba-barona Loisel., novedad para Espaňa, en Mallorca. Anales Jard. Bot. Madrid 47: 516. 
McPherson, J. K. \& Muller, C. H. (1969). Allelopathic effects of Adenostomafasciculatum, 'chamise', in the California chaparral. Ecological Monographs, 39: 177-198.

Menitsky, G.L., (1973). Supraspecific taxa in the genus Thymus L. (Labiatae). I-II. Botaniceskyj Zurnal (Leningrad) 58, 794-805.

Menitsky, G.L., (1973). Supraspecific taxa in the genus Thymus L. (Labiatae). I-II. Botaniceskyj Zurnal (Leningrad) 58, 994-998.

Messana, I., Ferrari, F., Souza, M.A.M., Gacs-Bait, E. (1990). (-)-Salzol, an isopimaranediterpene, and a chalcone from Hyptis salzmanii. Phitochemistry 29: 329-332.

Meudt, H. M., Clarke, A. C., 2007. Almost forgotten or latest practice? AFLP applications, analyses and advances. Trends Plant Sci. 12, 106-117.

Mockuté, D. and Bernotiené, G. (1998). Essential oil of lemon-scented Thymus pulegioides L. grown wild in Vilnius vicinity. Rust. Res., 34, 131-134.

Mockuté, D. and Bernotiené, G. (1999). The main citral-geraniol and cavacrol chemotype of the essential oil of Thymus pulegioides L. growing wild in Vilnius district. J. Agric. Food Chem., 47: 3787-3790.

Mockuté, D. and Bernotiené, G. (2001). The $\alpha$-terpenyl acetate chemotype of essential oil of Thymus pulegioides L. Biochem. Syst. Ecol. 29: 69-76.

Moghaddam, M., Omidbiagi, R., Naghavi, M.R., 2011. Evaluation of genetic diversity among Iranian accessions of Ocimum spp. using AFLP markers. Biochem. Syst. Ecol. 39: 619-626.

Moon, H.K., Hong, S.P., Smets, E., Huysmans, S. (2009a). Micromorphology and Character Evolution of Nutlets in Tribe Mentheae (Nepetoideae, Lamiaceae). Systematic Botany 34(4):760-776. 
Moon, H.K., Hong, S.P., Smets, E., Huysmans, S. (2009b). Phylogenetic significance of leaf micromorphology and anatomy in the tribe Mentheae (Nepetoideae: Lamiaceae). Botanical Journal of the Linnean Society160: 211-231.

Morales, R. (1986). Taxonomía de los géneros Thymus (excluida la sección Serpyllum) y Thymbra en la Península Ibérica. Ruizia 3: 1-324.

Morales, R. (1989). El género Thymus L. en la región mediterránea occidental (Lamiaceae). Biocosme Mésogéen 6(4): 205-211.

Morales, R. (1994). El género Thymus L. (Labiatae) en Africa. Anales Jard. Bot. Madrid 51(2): 205-236.

Morales, R. (1996). Studies on the genus Thymus. Lamiales Newsletter. 4: 6-8.

Morales, R. (1997). Synopsis of the Genus Thymus L. In the Mediterranean Area. Lagascalia 19 (1-2): 249-262.

Morales, R., (2002). The history, botany and taxonomy of the genus Thymus. In: Stahl-Biskup, E.,. Sáez, F. (Eds.), Thyme: The Genus Thymus. Taylor and Francis, London and New York, pp. 1-43.

Morone-Fortunato, I., Montemurro, C,. Ruta, C., Perrini, R., Sabetta, W., Blanco, A., Lorusso, E., Avato, P. (2010). Essential oils, genetic relationships and in vitro establishment of Helichrysum italicum (Roth) G. Don ssp. italicum from wild Mediterranean germplasm. Industrial Crops and Products 32: 639-649

Nedorostova, L., Kloucek, P., Kokoska, L., Stolcova, M., Pulkrabek, J. (2008). Antimicrobial properties of selected essential oils in vapour phase against foodborne bacteria. Food Control 20, 157-160.

Nei, M., Li, W.H., (1979). Mathematical model for studying genetic variation in terms of restriction endonucleases. Proceedings of the National Academy of Sciences 76, 5269-5273. 
Nixon, K.C., Wheeler, Q.D., (1990). An amplification of the phylogenetic species concept. Cladistics 6, 211-223.

Nguefacka, J., Tamguea, O., Lekagne Dongmoa, J.B., Dakolea, C.D., Lethb, V., Vismerc, H.F., Amvam Zolloa, P.H., Nkengfackd, A.E. (2012). Synergistic action between fractions of essential oils from Cymbopogon citratus, Ocimum gratissimum and Thymus vulgaris against Penicillium expansum. Food Control 23: 377-383.

Ortego, J., Bonal, R., (2009). Natural hybridisation between kermes (Quercus coccifera L.) and holm oaks (Q. ilex L.) revealed by microsatellite markers. Plant Biol.12, 234-238.

Özkan, M., Aktaş K., Özdemir C., Guerin, G. (2009). Nutlet morphology and its taxonomic utility in Salvia (Lamiaceae: Mentheae) from Turkey. Acta Bot. Croat. 68 (1): 105-115.

Pančić, J. (1865). Flora u okolini Beogradskoj. Državna Štamparija, Beograd.

Pančić, J. (1874). Flora Kneževine Srbije. Državna Štamparija, Beograd.

Pančić, J. (1884). Dodatak Flori kneževine Srbije. Kralj.-Srp. Državne Štamparije, Beograd.

Paolini, J., Falchi, A., Quilichini, Y., Desjobert, J.M., De Cian, M.C., Varesi, L., Costa, J. (2009). Morphological, chemical and genetic differentiation of two subspecies of Cistus creticus L. (C. creticus subsp. eriocephalus and C. creticus subsp. corsicus). Phytochemistry 70: 1146-1160.

Passet, J. (1971). Thymus vulgaris L. chemotaxonomie et biogenese monoterpenique: (These Univ. Montpellier.) 153p.. Ref. in Bull. Signal., Biol. Physiol. Veg., 33(5): 4564 (1972)

Paton, A.J., Springate, D., Suddee, S., Otieno, D., Grayer, R.J., Harley, M., Willis, F., Simmonds, M.S.J., Powel,1 M., Savolainen, V., (2004). Phylogeny and evolution of Basils and allies (Ocimeae, Labiatae) based on three plastid DNA regions. Molec. Phylogenet. Evol. 31, 277-299. 
Patwardhan, S.A., Gupta A.S. (1981). An octomethoxy flavones from Pogostemon purporosceus. Phytochemistry 20: 1458.

Pau, L. (1929). Introducci6n a1 estudio de 1os tomillos españoles. Mem. Real. Soc. Esp. Hist. Nut. 5: 65-71.

Petrović, S. (1882). Flora okoline Niša. Kralj.-Srp. Državne Štamparije, Beograd.

Petrović, S. (1885). Dodatak flori okoline Niša. Kralj.-Srp. Državne Štamparije, Beograd.

Pluhár, Zs., Héthelyi, É., Kutta, G., Kamondy, L. (2007). Evaluation of environmental factors influencing essential oil quality of Thymus pannonicus All. and Thymus praecox Opiz. J. Herbs Spices Med. Plants. 3: 23-43

Prather, L.A., Monfils, A.K., Posto, A.L., Williams, R.A., (2002). Monophyly and phylogeny of Monarda (Lamiaceae): implications of sequence data from the internal transcribed spacer (ITS) region of nuclear ribosomal DNA. Syst. Bot. 27, 127-137.

Pritchard, J.K., Stephens, M., Donnelly, P. (2000). Inference of population structure using multilocus genotype data. Genetics 155, 945-959.

Rahimmalek, M., Tabatabaei, B.E.S., Arzani, A., Etemadi, N. (2009). Assessment of genetic diversity among and within Achillea species using amplified fragment length polymorphism (AFLP). Biochem. Syst. Ecol. 37, 354-361.

Richard, H., Benjilali, B., Banquour, N. and Baritaux, 0 . (1985) Étude de diverses huiles essentielles de Thym du Maroc. Lebensm.-Wiss. u. -Techno[., 18: 105-110.

Rigano, D., Formisano, C., Basile, A., Lavitola, A., Senatore1, F., Rosselli, S., Bruno, M. (2007). Antibacterial Activity of Flavonoids and Phenylpropanoids from Marrubium globosum ssp. libanoticum, Phytother. Res. 21: 395-397.

Ristić, M.D., Duletić-Laušević, S., Knežević-Vukčević, J., Marin, P.D., Simić, D., Vukojević, J., Janaćković, P., Vajs, V. (2000). Antimicrobial activity of essential 
oils and ethanol extract of Phlomis fruticosa L. (Lamiaceae), Phytotherapy Research, 14 (4): 267-271.

Rodriguez, B. (1977). 5,4'-dihydroxy-6,7,8,3'-tetrametoxyflavone from Sideritis mugronensis. Pytochemistry 16: 800.

Rohlf, F.J. (2000). NTSYS-pc. Numerical taxonomy and multivariate analysis system, version 2.1. Exeter Publications, New York.

Rota, M.C., Herrera, A., Martínez, R.M., Sotomayor, J.A., Jordán, M.J. (2008). Antimicrobial activity and chemical composition of Thymus vulgaris, Thymus zygis and Thymus hyemalis essential oils. Food Control 19, 681-687.

Ruiz, E., Marticorena, C., Crawford, D., Stuessy, T., Gonzalez, F., Montoya, R., Silva, M., Becerra, J. (2001). Morphological and ITS sequence divergence between taxa of Cuminia (Lamiaceae), an endemic genus of the Juan Fernandez Islands, Chile. Brittonia 52, 341-350.

Saad, A., Fadli, M., Bouaziz, M., Benharref, A., Mezrioui, N.E., Hassani, L., 2010. Anticandidal activity of the essential oils of Thymus maroccanus and Thymus broussonetii and their synergism with amphotericin $\mathrm{B}$ and fluconazol. Phytomedicine 17, 1057-1060.

Sáez, F.,Stahl-Biskup, E. (2002). Essential oil polymorphism in the genus Thymus. In: Stahl Biskup, E., Sáez, F. ed(s). Thyme: the genus Thymus. (Medicinal and aromatic plants: industrial profiles; v.24.). London: Taylor and Francis pp. 126-143.

Safer, S., Tremetsberger, K., Guo, Y.-P., Kohl, G., Samuel, M. R., Stuessy, T. F., Stuppner, H. (2011). Phylogenetic relationships in the genus Leontopodium (Asteraceae: Gnaphalieae) based on AFLP data. Bot. J. Linn. Soc. 165, 364-377.

Safaei-Ghomi, J., Ebrahimabadi, A.H., Djafari-Bidgoli. Z., Batooli, H. (2009). GC/MS analysis and in vitro antioxidant activity of essential oil and methanol extracts of Thymus caramanicus Jalas and its main constituent carvacrol. Food Chemistry 115: 1524-1528. 
Saitou, N., Nei, M. (1987) The neighbor-joining method: a new method for reconstructing phylogenetic trees. Mol. Biol. Evol. 4 (4), 406-25.

Sakagami, Y., Iinuma, M., Piyasena, K.G.N.P., Dharmaratne, H.R.W., 2005. Antibacterial activity of a-mangostin against vancomycin resistant Enterococci (VRE) and synergism with antibiotics. Phytomedicine 12, 203-208.

Salmaki, Y., Zarre, S. Jamzad, Z. (2008). Nutlet micromorphology and its systematic implication in Stachys L. (Lamiaceae) in Iran. Feddes Repertorium 119 7-8: 607-621.Sang, T., Crawford, D.J., Stuessy, T.F. (1995). Documentation of reticulate evolution in peonies (Paeonia) using internal transcribed spacer sequences of nuclear ribosomal DNA: Implications for biogeography and concerted evolution. Proceedings of the National Academy of Sciences of the United States of America $92,6813-6817$.

Salgueiro, L. R., Vila, R., Tomi, F., TomBs, X., Cafiigueral, S., Casanova, J., Proenga da Cunha, A., Adzet, T. (1997). Composition and infraspecific variability of essential oil from Thymus camphoratus. Phytochemistry 45: 1177-1183.

Schmidt-Lebuhn, A.N. (2007). Using amplified fragment length polymorphism (AFLP) to unravel species relationships and delimitations in Minthostachys (Labiatae). Bot. J. Linn. Soc. 153, 9-19.

Schmidt-Lebuhn, A.N., (2008). Monophyly and phylogenetic relationships of Minthostachys (Labiatae, Nepetoideae) examined using morphological and nrITS data. Plant Syst. Evol. 270, 25-38.

Schneider, S., Roessli, D., Excoffier, L . (2000). Arlequin: a software for population genetic data. Genetics and Biometry Laboratory, University of Geneva, Switzerland.

Schulte, K., Silvestro, D., Kiehlmann, E., Vesely, S., Novoa, P., Zizka, G. (2010). Detection of recent hybridization between sympatric Chilean Puya species (Bromeliaceae) using AFLP markers and reconstruction of complex relationships. Molecular Phylogenetics and Evolution 57, 1105-1119. 
Shonle, I., Bergelson, J. (2000). Evolutionary ecology of the tropane alkaloids of Datura stramonium L. (Solanaceae). Evolution 54: 778-788.

Simonović, D. (1959). Botanički rečnik imena biljaka. SANU, Beograd.

Simeon de Bouchberg, M., Allegrini, J., Bessiere, C., Attisso, M., Passet, J., Granger, R. (1976) Proprietiès microbiologiques des huiles essentielles de chimiotypes de Thymus vulgaris L. Riv. Ital., 58: 527-536.

Slavkovska, V., Lakusic, B., Jancic, R., Mimica-Dukic, N. and Vujicic, D. (2006). Chemical Composition of the Essential Oil of Thymus bracteosus Vis. ex Bentham (Lamiaceae). J. Essent. oil Res. 18: 310-311.

Soković, M.D., Marin P D, Simić, D., Knežević-Vukčević, J., Vajs, V., Petrović, S. (2002). Antimutagenic activity of essential oil and crude extract of Phlomis fruticosa, Pharmaceutical Biology. 40 (4): 311-314.

Soković, M., Marin, P., Brkić, D., Van Griensven, L.J.L.D. (2007). Chemical composition and antibacterial activiy of essential oils of ten aromatic plants against human pathogenic bacteria. Food Global Science Books, 1(2), 220-226.

Soković, M., Glamoclija, J., Ćirić, A., Kataranovski, D., Marin, P.D., Vukojević, J., Brkić, D. (2008). Antifungal activity of the essential oil of Thymus vulgaris L. and thymol on experimentally induced dermatomycoses. Drug Development and Industrial Pharmacy34 (12) 1388-1393

Soković, M.D., Vukojević, J., Marin, P.D., Brkić, D.D., Vajs, V., Van Griensven L.J.L.D. (2009) Chemical composition of essential oils of Thymus and Mentha species and their antifungal activities. Molecules, 14 (1):238-249.

Solitis, D., Soltis, P. (2000). Choosing an aproach and appropriate gene for phylogenetic analysis. In: Soltis, D., Soltis,P., Doyle, J.J. (eds) Molecular systematic of plants II, DNA sequencing. Kulwer academic Publishers, Boston, Dordrecht, London: 1-42. 
Stahl-Biskup, E. (1986). Das ätherische Öl norwegischer Thymianarten II. Thymus pulegioides. Planta Med. 52: 223-235.

Stahl-Biskup, E. (2002). Essential oil chemistry of the genus Thymus - a global view. In: Letchamo W, Saez F, Stahl-Biskup E (eds) Medicinal and aromatic plantsindustrial profiles: the genus Thymus. Harwood Academic, Amsterdam: 75-124.

Sulamian, S.F., Culham, A., Harborne, J.B. (2003). Molecular Phylogeny of Fabaceae based on $r b c \mathrm{~L}$ sequence data: With special emphasis on the tribe Mimoseae (Mimosoideae). As. Pac. J. Mol. Biol. Biotechnol., Vol. 11 (1): 9-35.

Swain, T. (1975). Evolution of flavonoid compounds. In: Harborne, J.B., Marby, T,J., Mabry, H. (EdS), The Flavonoids. Chapman and Hall, London.1096-1129.

Šilić, Č. (1979). Monografija rodova Satureja L., Calamintha Miller, Micromeria Bentham, Acinos Miller i Clinopodium L. U flori Jugoslavije. Zemaljski muzej BiH. Sarajevo.

Takagi, S., Yamaki, M., Inoue, K. (1981). Flavone di-C-glucosides from Scutellaria baicalensis, Phytochemistry 20 (10): 2443-2444.

Thompson, J.D. (2002) Population structure and the spatial dynamics of genetic polymorphisms in thyme. In: Letchamo W, Saez F, Stahl-Biskup E (eds) Medicinal and aromatic plants-industrial profiles: the genus Thymus. Harwood Academic, Amsterdam: 44-74.

Thompson, J.D., Chalchat, J.-C., Michet, A., Linhart, Y.B., Ehlers, B. (2003). Qualitative and quantitative variation in monoterpene co-occurrence and composition in the essential oil of Thymus vulgaris chemotypes. Journal of Chemical Ecology 29(4): 859-880.

Tomás, F., Nieto, J.L., Barberán, F.A.T., Ferreres, F. (1986). Flavonoids from Phlomis lychnitys. Phytochemistry 25, 1253-1254.

Tomás-Barberán, F.A., Wollenweber, E. (1990). Flavonoid aglycones from the leaf surfaces of some Labiatae species. Pl. Syst. Evol. 173. (3-4): 109-118. 
Tomás-Barberán, F.A., Gil, M.I. (1992). Chemistry and natural distribution of flavonoids in the Labiatae. In: Harley, R.M., Reynolds, T. (Eds.), Advances in Labiate Science. Royal Botanic Gardens, Kew, pp. 299-305.

Tomás-Barberán, F.A., Gil, M.I., Marin, P.D., Tomás-Lorente, F. (1991). Flavonoids from some Yugoslavian Micromeria species: chemotaxonomical aspects. Biochem. Syst. Ecol. 19. (8): 697-698.

Tomás-Barberán, F.A., Husain, S.Z., Gil, M.I. (1988). The distribution of methylated flavones in the Lamiaceae. Biochem. Syst. Ecol. 16: 43-46.

Tomás-Lorente, F., Ferreres, F., Tomás-Barberán, F.A., Rivera, D., Obón, C. (1989). Verification of Sideritis incana $x$ S. angustifolia hybrids by flavonoid analysis. Phytochemistry 28 (8): 2141-2143.

Tomimori, T., Miyaichi, Y., Imoto, Y., Kizu, H., Namba, T. (1985). Studies of Nepalese crude drugs. V. On the flavonoid constituents of the root of Scutellaria baicalensis Colebr. (1). Chem. Pharm. Bull. 33: 4457-4463.

Tomimori, T., Miyaichi, Y., Imoto, Y., Kizu, H., Suzuki, C. (1984)Studies of the constituents of Scutellaria species. IV. On the flavonoid constituents of the root of Scutellaria baicalensis Georggi (4). J. Pharm. Soc. Japan 104: 529-534.

Trindade, H., Costa, M.M., Lima, A.S., Pedro, L.G., Figueiredo, A.C., Barroso, J.G. (2008). Genetic diversity and chemical polymorphism of Thymus caespititius from Pico, Saõ Jorge and Terceira islands (Azores). Biochem. Syst. Ecol. 36, 790-797

Trindade H., Costa, M.M., Lima, S.B., Pedro, L.G., Figueiredo, A.C., Barroso J.G. (2009). A combined approach using RAPD, ISSR and volatile analysis for the characterization of Thymus caespititius from Flores, Corvo and Graciosa islands (Azores, Portugal). Biochem. Syst. Ecol. 37, 670-677

Trusty, J., Olmstead, R.G., Bogler, D.J., Santos-Guerra, A., Francisco-Ortega, J. (2004). Using molecular data to test a biogeographic connection of the Macaronesian genus Bystropogon (Lamiaceae) to the New World: a case of conflicting phylogenies. Syst. Bot. 29, 702-715. 
Trusty, J.L., Olmstead, R.G., Santos-Guerra, A., Sa-Fontinha, S., Francisco-Ortega, J. (2005). Molecular phylogenetic of the Macaronesian endemic genus Bystropogon (Lamiaceae): palaeo-islands, ecological shifts and interisland colonizations. Mol. Ecol. 14, 1177-1189.

Van de Peer, Y., De Wachter, Y. (1994). TREECON for Windows: a software package for the construction and drawing of evolutionary trees for the Microsoft Windows environment. Comput. Applic. Biosci. 10, 569-570.

Velasco Negueruela, A. and Perez Alonso, M.J. (1986) Aceites esenciales de tomillos ibericos. VI. Contribuci6n a1 estudio quimiotaxondmico (Terpenoides) del genero Thymus L. Trab. Dep. Bothica 13: 115-133.

Velenovsky, J. (1906). Vorstudien zu einer Monographie der Gattung Thymus L. Bot. Zentralhl. Beih., 19 B2: 271-287.

Venturella, P., Bellino, A., , M.L., Sorrentino, M. (1980). Aurapin, a new dihydroflavonol glycoside and other flavonoids from Acinos alpinus. Heterocycles 14 (12): 1979-1982.

Vernet, P., Gouyon, P.H., Valdeyron, G. (1986). Genetic control of the oil content in Thymus valgaris L.: a case of polymorphism in a biosynthetic chain. Genetics, 69: 227-231.

Vernet, P., Guillerm, J.L., Gouyon, P.H. (1977a). Le polymorphisme chimique de Thymus vulgaris L. (Labiée) I. Repartition des formes chimiques en relation avec certains facteurs écologiques. Oecol. Plant., 12, 159-179.

Vernet, P., Guillerm, J.L., Gouyon, P.H. (1977b). Le polymorphisme chimique de Thymus vulgaris L. (Labiée) 11. Carte 2 l'echelle 1125000 des formes chimiques dans la region de Saint-Martin-de-Londres (Herault-France). Oecol. Plant., 12, 18 1194.

Vicioso, C. (1974) Contribución al conocimiento de los tomillos españoles. In: J. Ruiz del Castillo (ed.), Anales Inst. Nac. Invest. Agrar. ser. Recursos Nat., 1: 11-63. 
Vos, P., Hogers, R., Bleeker, M., Reijans, M., van de Lee, T., Hornes, M., Frijters, A., Pot, J., Peleman, J., Kuiper, M., Zabeau., M. (1995). AFLP: A new technique for DNA fingerprinting. Nucleic Acids Res. 23, 4407-4414.

Wagstaff, S. J., Olmstead, R. G., Cantino, P.D. (1995). Parsimony analysis of cpDNA restriction site variation in subfamily Nepetoideae (Labiatae) . American Journal of Botany 82: $886-892$.

Wagstaff, S. J., Olmstead, R. G. (1997). Phylogeny of Labiatae and Verbenaceae inferred from $r b c$ L sequences. Syst. Bot. 22:165-179.

Walker, J.B., Sytsma, K.J. (2007). Staminal evolution in the genus Salvia (Lamiaceae): molecular phylogenetic evidence for multiple origins of the staminal lever. Ann. Bot. 100, 375-391.

Walker, J.B., Sytsma, K.J., Treutlein, J., Wink, M. (2004). Salvia (Lamiaceae) is not monophyletic: implications for the systematics, radiation, and ecological specializations of Salvia and tribe Mentheae. Am. J. Bot. 91, 1115-1125.

Wang, H.K., Xia, Y., Yang, Z.Y., Natschke, S.L., Lee, K.H. (1998). Recent advances in the discovery and development of flavonoids and their analogues as antitumor and anti-HIV agents. Adv Exp Med Biol. 439, 191-225.

Willkomm, M. (1868). Labiatae. In M. Willkomm and J. Lange (eds), Prodr. Fl. Hisp., 96. vol. 2, Stuttgart: 389-480.

Young, D.A., Sterner, R.W. (1981). Leaf flavonoids of primitive dicotyledonous angiosperms: Degeneria vitiensis and Idiospermum australiense. Biochem. Syst. Ecol. 9: 185-188.

Zouaria, N., Fakhfakhc, N., Zouarid, S., Bougatefc, A., Karraya, A., Neffati, M., Ayadie, M.A. (2011). Chemical composition, angiotensin I-converting enzyme inhibitory, antioxidant and antimicrobial activities of essential oil of Tunisian Thymus algeriensis Boiss. et Reut. (Lamiaceae). Food and Bioproducts Processing 89: 257-265. 


\section{Biografija autora}

Ivan Šoštaarić rođen je 16. Januara 1971. godine u Beogradu. U Beogradu je završio osnovnu školu 1985. godine i gimnaziju 1989. godine. Diplomirao je na Biološkom fakultetu Univerziteta u Beogradu 2001. godine, sa prosečnom ocenom 8,41 i ocenom 10 na diplomskom ispitu. Dokotrske studije upisao je 2006. godine na Biološkom fakultetu Univerziteta u Beogradu. Govori engleski i francuski jezik.

Od 2002. godine zaposlen je na Katedri za agrobotaniku, Poljoprivrednog fakulteta Univerziteta u Beogradu. Učestvovao je na dva nacionalna projekta i jednom međunarodnom projektu. Tri puta je boravio na stručnom usavršavanju u Jodrell Laboratory, Royal Botanical Gardens, Kew, Ujedinjeno Kraljevstvo.

Prvi autor je dva rad objavljena u časopisima međunarodnog značaja i koautor tri radova u časopisima međunarodnog značaja i jednog rad objavljenog u časopisu domaćeg značaja, kao i većeg broja kongresnih saopštenja. 
Прилог 1.

\section{Изјава о ауторству}

Потписани-а Иван Шоштарић

број уписа EB 060011

\section{Изјављујем}

да је докторска дисертација под насловом

Фитохемијска и генетичка варијабилност врста из секције Serpyllum (Mill.) Benth. рода Thymus L. (Lamiaceae) y Србији

- резултат сопственог истраживачког рада,

- да предложена дисертација у целини ни у деловима није била предложена за добијање било које дипломе према студијским програмима других високошколских установа,

- да су резултати коректно наведени и

- да нисам кршио/ла ауторска права и користио интелектуалну својину других лица.

Потпис докторанда

У Београду, 31.08.2012.

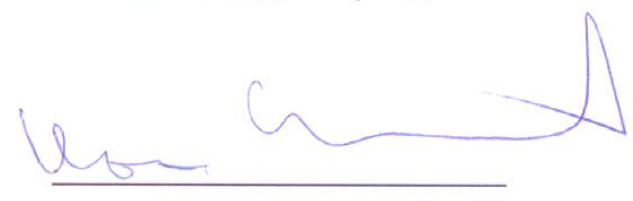


Прилог 2.

\title{
Изјава о истоветности штампане и електронске верзије докторског рада
}

\author{
Име и презиме аутора _ـ Иван Шоштарић \\ Број уписа \\ EB 060011 \\ Студијски програм \\ Експериментална и примењена ботаника \\ Наслов рада Фитохемијска и генетичка варијабилност врста из секције Serpyllum \\ (Mill.) Benth. рода Thymus L. (Lamiaceae) у Србији \\ Ментор Проф. др Петар Марин, Проф. др Зора Дајић Стевановић \\ Потписани __ Иван Шоштарић
}

изјављујем да је штампана верзија мог докторског рада истоветна електронској верзији коју сам предао/ла за објављивање на порталу Дигиталног репозиторијума Универзитета у Београду.

Дозвољавам да се објаве моји лични подаци везани за добијање академског звања доктора наука, као што су име и презиме, година и место рођења и датум одбране рада.

Ови лични подаци могу се објавити на мрежним страницама дигиталне библиотеке, у електронском каталогу и у публикацијама Универзитета у Београду.

Потпис докторанда

У Београду, 31. 08. 2012 
Прилог 3.

\section{Изјава о коришћењу}

Овлашћујем Универзитетску библиотеку „Светозар Марковић“ да у Дигитални репозиторијум Универзитета у Београду унесе моју докторску дисертацију под насловом:

Фитохемијска и генетичка варијабилност врста из секције Serpyllum (Mill.) Benth. рода Thymus L. (Lamiaceae) у Србији

која је моје ауторско дело.

Дисертацију са свим прилозима предао/ла сам у електронском формату погодном за трајно архивирање.

Моју докторску дисертацију похрањену у Дигитални репозиторијум Универзитета у Београду могу да користе сви који поштују одредбе садржане у одабраном типу лиценце Креативне заједнице (Creative Commons) за коју сам се одлучио/ла.

1. Ауторство

2. Ауторство - некомерцијално

3. Ауторство - некомерцијално - без прераде

(4.)Ауторство - некомерцијално - делити под истим условима

5. Ауторство - без прераде

6. Ауторство - делити под истим условима

(Молимо да заокружите само једну од шест понуђених лиценци, кратак опис лиценци дат је на полеђини листа).

Потпис докторанда

У Београду, 31. 08. 2012. 